
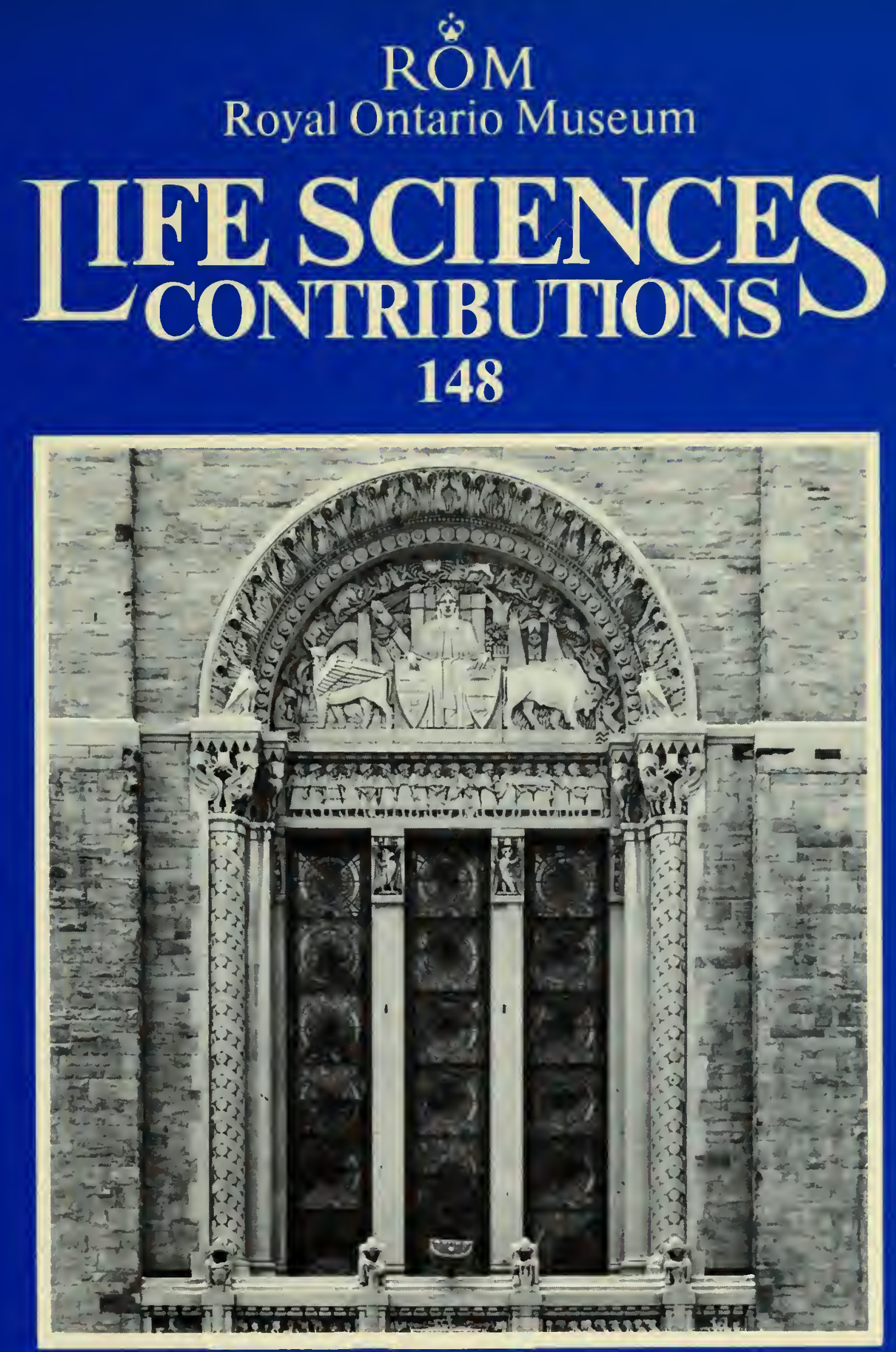

\title{
Shallow-Water Hydroids of Bermuda The Athecatae
}

Dale R. Calder 


\section{ROYAL ONTARIO MUSEUM LIFE SCIENCES PUBLICATIONS INSTRUCTIONS TO AUTHORS}

Authors should prepare their manuscripts carefully according to the following instructions; failure to do so will result in the manuscript's being returned to the author for revision. All manuscripts are considered on the understanding that they are not currently offered for publication elsewhere.

1. General Papers for publication are accepted from ROM staff members and research associates, and from researchers reporting on work done with ROM collections. Monographs on the flora and/or fauna of Ontario may be considered for publication by authors not affiliated with the ROM. Financial contributions towards publication will be welcome. Authors are expected to write clearly and concisely and to omit any material not essential for an understanding of the main theme of the paper.

2. Format Manuscripts (including captions, synonymies, literature cited, and tables) should be typed with double space on $11^{\prime \prime} \times 8 \frac{1}{2}{ }^{\prime \prime}$ paper with a $1 \frac{1}{2}$ " margin on all sides. Three xerox copies should be submitted to the Senior Editor of the Editorial Board; the original should be retained by the author(s). The submission should include a separate sheet giving the author(s) names and affiliations, the title of the publication, the series for which it is submitted, the number of typed pages, the number of tables, and the number of plates or figures. Manuscripts should normally be organized in the following order: Contents, Abstract, Introduction, Materials and Methods, Results, Discussion, Conclusions, Summary (if manuscript is long), Acknowledgements, Appendices, and Literature Cited. Authors are encouraged to include foreign-language translations of the Summary, if appropriate. Main headings should be centred; subheadings should be left-justified to the text margin. The first line of the first paragraph in each new section should not be indented. Literature citations in the text should be in the form "Jones (1972)" or "(Jones, 1972)" or "(Smith, 1960:71-79, fig. 17)".

3. Standard Sources The primary authority on questions of format and style is Guide to Authors, available from ROM Publication Services. For matters not covered in the Guide, consult CBE Style Manual (Fifth Edition). Other standard sources are as follows: for
English spelling, The Concise Oxford Dictionary; for Canadian place names and coordinates, Canada Gazetteer Atlas; for the spelling of geographic names, The Times Atlas.

4. Abstract All papers must be preceded by a short, factual abstract, about one per cent of the text in length. The abstract may be followed by four to six key words in parentheses.

5. Taxonomy The name of a taxon should be given in full in headings, at the beginnings of paragraphs, and at its first occurrence in the text. Give the authority and date, if appropriate, with the first mention of each taxon, but not thereafter. Taxonomic papers, particularly synonymies, should follow the layout in Life Sciences Contributions beginning with No. 136. International Codes of Biological Nomenclature must be followed.

6. Literature Cited A complete list of references, in alphabetical order of authors, must be given at the end of the paper. When two or more works of one author are cited, they should be listed chronologically. The names of journals should not be abbreviated. For correct bibliographic form, see Life Sciences Contributions beginning with No. 136.

7. Tables All tables should be typed on separate sheets and numbered consecutively in arabic numerals in the order of their first mention in the text. Mark the location of each table in the margin of the text.

8. Plates, Figures, and Text-figures Illustrations may be designated according to the conventions of the author's discipline; in some disciplines grouped photographs of scientific subject matter are commonly termed Plates, while line drawings and locality and other illustrations that occupy a full page or less are Text-figures. Usage must be consistent throughout the paper. A full-page illustration for a Contribution, with its caption, should be sized to fit an area of $17.3 \times$ $22.75 \mathrm{~cm}$; for Occasional Papers, the area is $14.1 \times$ $21.2 \mathrm{~cm}$. If captions are lengthy, they may be placed on the facing page. A scale or magnification factor should be included. Authors are reminded that when illustrations are reduced magnification factors will change, and that they are responsible for the conversion. For details, see Guide to Authors. 


\title{
Shallow-Water Hydroids of Bermuda The Athecatae
}

\author{
Dale R. Calder
}


The Royal Ontario Museum publishes three series in the Life Sciences. CONTRIBUTIONS: a numbered series of original scientific publications.

OCCASIONAL PAPERS: a numbered series of original scientific publications, primarily short and of taxonomic significance.

MISCELLANEOUS PUBLICATIONS: an unnumbered series on a variety of subjects.

All manuscripts considered for publication are subject to the scrutiny and editorial policies of the Life Sciences Editorial Board, and to independent refereeing by two or more persons, other than Museum staff, who are authorities in the particular field involved.

LIFE SCIENCES EDITORIAL BOARD

Senior editor: J. L. Eger

Editor: D. C. Darling

Editor: R. W. Murphy

External editor: C. S. Churcher

Manuscript editor: J. C. Barlow

Production editor: J. E. Hawken

Dale R. Calder is associate curator in charge in the Department of Invertebrate Zoology, Royal Ontario Museum, and associate professor in the Department of Zoology, University of Toronto.

\section{Canadian Cataloguing in Publication Data}

Calder, Dale R.

Shallow-water hydroids of Bermuda : the Athecatae

(Life sciences contributions, ISSN 0384-8159; 148)

Bibliography: $\mathrm{p}$.

Includes index.

ISBN 0-88854-339-5

1. Hydroida. 2. Coelenterata - Bermuda.

I. Royal Ontario Museum. II. Title. III. Series.

QL377.H9C35 I988 593.7'I'097299 C88-093898-6

Publication date: I5 June 1988

ISBN 0-88854-339-5

ISSN 0384-8I59

(C) Royal Ontario Museum, I988

100 Queen's Park, Toronto, Canada M5S 2C6

PRINTED AND BOUND IN CANADA AT UNIVERSITY OF TORONTO PRESS 


\section{Contents}

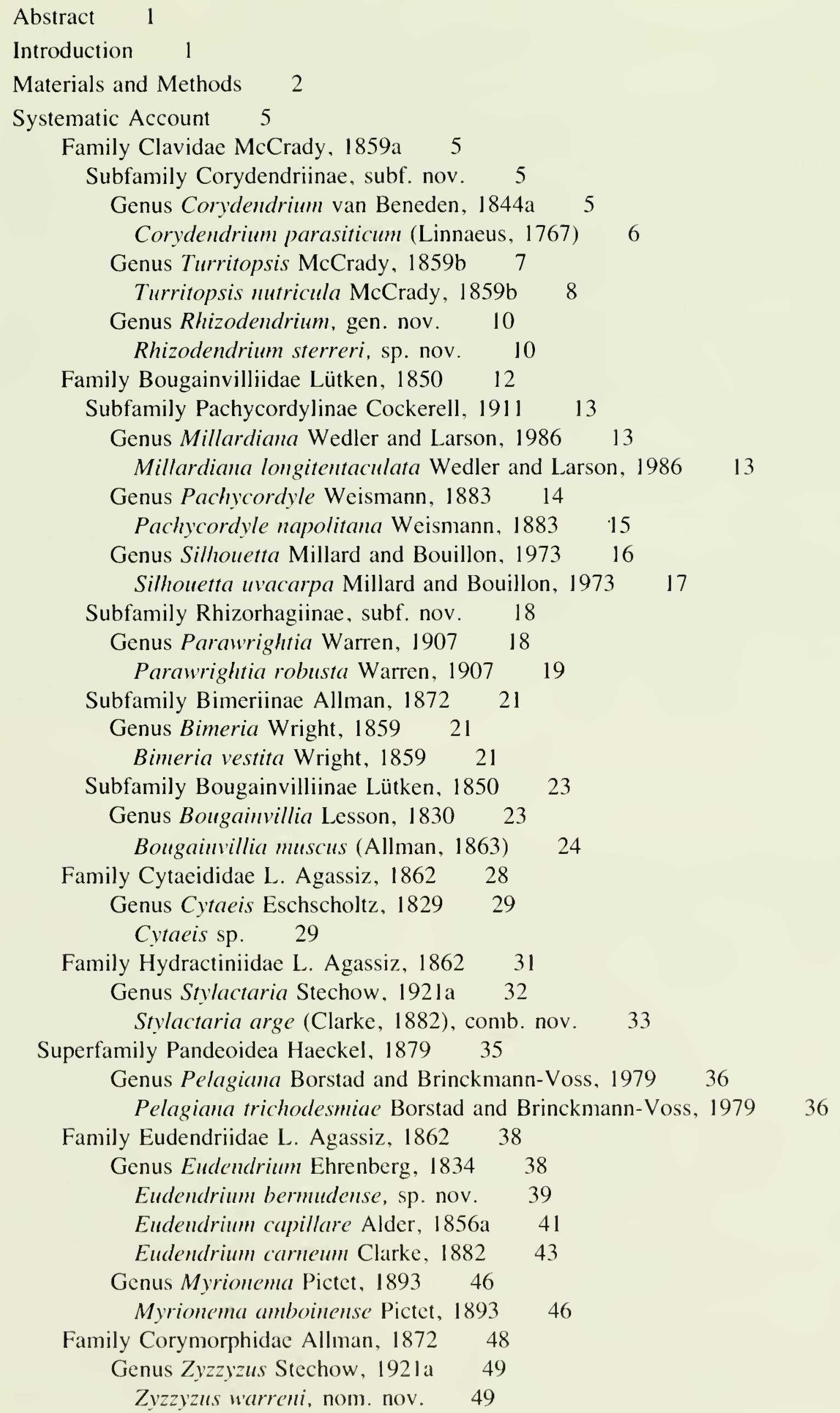


Family Tubulariidae Fleming, $1828 \quad 52$

Genus Ectopleura L. Agassiz, 186252

Ectopleura pacifica Thornely, $1900 \quad 53$

Family Halocordylidae Stechow, 1921a 55

Genus Halocordyle Allman, 187255

Halocordyle disticha (Goldfuss, 1820) 56

Family Sphaerocorynidae Prévot, 195960

Genus Sphaerocoryne Pietet. $1893 \quad 60$

Sphacrocoryme bedoti Pictet, $1893 \quad 61$

Family Corynidae Johnston, $1836 \quad 63$

Genus Corme Gaertner, $1774 \quad 63$

Corve sargassicola. sp. nov. 64

Family Cladonematidae Gegenbaur, 185766

Genus Cladonema Dujardin, 1843a 66

Cladonema radiatum Dujardin. 1843a

Family Zancleidae Russell, 195368

Genus Zanclea Gegenbaur, $1857 \quad 69$

Zanclea alba (Meyen, 1834), comb. nov.

Family Milleporidae Fleming. 182872

Genus Millepora Linnaeus, 175873

Millepora alcicornis Linnaeus, 1758

Family Porpitidae Goldfuss, $1818 \quad 76$

Genus Porpita Lamarck, 180177

Porpita porpita (Linnaeus, 1758) 77

Genus Velella Lamarek, $1801 \quad 80$

Velella velella (Linnaeus, 1758) 81

Acknowledgements $\quad 84$

Literature Cited 85

Index 103 


\title{
Shallow-Water Hydroids of Bermuda \\ The Athecatae
}

\begin{abstract}
The shallow-water athecate hydroids known from Bermuda and vicinity, comprising 26 species in 24 genera, are surveyed. Synonymies are updated for each family-, genus-, and species-group taxon represented. Six taxa are described as new to science: Corydendriinae, subf. nov., Rhizorhagiinae, subf. nov., Rhizodendrium, gen. nov., Rhizodendrium sterreri, sp. nov., Eudendrium bermudense, sp. nov., and Coryne sargassicola, sp. nov. Zyzzyzus warreni is proposed as a replacement name for the junior primary homonym Tubularia solitaria Warren, 1906b (not Tubularia solitaria Rapp, 1829). The tribe Pachycordylini Cockerell, 1911, is elevated to the rank of subfamily. Pachycordyle Weismann, 1883, Parawrightia Warren, 1907, and Stylactaria Stechow, 1921a, are reestablished as the valid names of genera. Tubularia muscoides Linnaeus, 1761, is designated as type species of the nominal genus Fistulana O. F. Müller, 1776a. A lectotype is designated for the conglomerate Podocoryne alderi Hodge, 1861, a nominal species based on hydroid and medusa stages referable to different genera. The invalid name Bougainvillia ramosa (van Beneden, 1844a) is replaced with the name Bougainvillia muscus (Allman, 1863).

Descriptions and illustrations are provided for each species studied, and data on nematocyst complement and size are given for all but one of them. Of the 26 species discussed, 23 occur elsewhere in the western Atlantic and 9 are reportedly circumglobal in warm waters. Eleven of the 23 previously known species are reported from Bermuda for the first time.
\end{abstract}

\section{Introduction}

Hydroids of the oceanic island of Bermuda have been the subject of several previous investigations. The most comprehensive taxonomic accounts to date have been by Congdon (1907) and Bennitt (1922). Hydroids collected by H.M.S. Challenger on Challenger Bank in the vicinity of Bermuda were discussed by Allman (1888) and Ritchie (1909). Reports by Verrill $(1900,1907)$, Smallwood (1910), Stechow (1912), Jäderholm (1920), and Moore (1969) discussed one or more hydroid species from the Bermuda platform. Fraser (1944) included most of the species known from the area, based on literature records. Calder (1986) listed common and otherwise noteworthy hydrozoan species. Hydroids on pelagic Sargassum were studied by Burkenroad (in Parr, 1939), by Morris and Mogelberg (1973), and by Ryland (1974). Morphological, developmental, and physiological investigations have been undertaken on Bermuda material by Congdon (1906), Cowden (1965a, 1965b), Summers (1972a), Lesh-Lauric (1976), and Clark and Cook (1986). Accounts of the neustonic species Porpita porpita (Linnaeus, 1758) and Velella velella (Linnacus, 1758) in
Bermudian waters have been published by Fewkes (1883), Verrill (1900), Bigelow (1918), Totton (1936), and Calder (1986). Millepora alcicornis Linnaeus, 1758, a conspicuous member of the Bermudian coral reef community, has been mentioned in papers such as those of Nelson and Duncan (1876), Moseley (1876, 1879, 1880), Rice (1878), Quelch (1886), Verrill (1900, 1902a, 1902b, 1907), Moore (1969), and Calder (1986).

The purpose of this report was to provide a taxonomic account of the athecate hydroids currently known from Bermuda and vicinity, to a depth of $100 \mathrm{~m}$, based largely on collections made by the author since 1977. The athecate fauna of the study area is rather depauperate, accounting for only about one-quarter of the total number of hydroid species known from Bermuda (Calder, unpublished data). A decision was made early in the study to include as complete a synonymy of each family-, genus-, and speciesgroup taxon as possible. Original spellings of the names of taxa were verified, authorship and dates of these names were rechecked, and matters of nomencliture were con- 
sidered according to provisions of the International Code of Zoological Nomenclature (International Commission on Zoological Nomenclature [ICZN], 1985). Some of the nomenclatural problems encountered hatve been resolved here. while others will require submissions to the commission.

Questions regarding the identity, synonymy, and systematic positions of taxa arose repeatedly during the course of this study. One quandary in particular involved the extent to which nominal species should be combined or divided. The hydrozoan literature is replete with extremes of taxonomic "lumping" and "splitting." and the confusion resulting from both. For example, Duchassaing and Michelotti (1864) viewed practically every morphological form of the hydrocoral Millepora Linnaeus, 1758, from the Caribbean as a distinct species, whereas Hickson (1898a. 1898b) recognized only one species in the genus worldwide. Most authors now follow Boschma (1948) in recognizing three species in the Caribbean, and about a dozen worldwide. Nevertheless, determining how far to go in combining or splitting nominal species is largely a matter of personal opinion. Most recent hydrozoan systematists have tended to be "taxonomic lumpers," and generally broad taxa have been recognized here. Reasons why relatively few species of hydroids are believed to exist worldwide were briefly stated by Cornelius (1981).

Related to the question of lumping or splitting of taxa is the interpretation of hydroid species distribution. According to literature records, many species of hydroids are virtually cosmopolitan. Admittedly, certain hydroids are well adapted for long-range dispersal, and their rate of speciation seems to be rather slow (Cornelius, 1981). Yet the question arises whether some species are as widely distributed as records indicate, or whether their reported range is partly an artifact of the hydrozoan taxonomist's inability to discriminate distinct but closely related species.

Hydrozoan classification is complicated by many factors, including the following: (1) the existence of separate hydroid and medusa generations in many species; (2) the legacy of separate classifications for hydroids and medusae; (3) the production of free medusae and fixed gonophores in closely related species; (4) the differential reduction of male and female gonophores in certain species: (5) the production in some taxa of morphologically dissimilar medusae by virtually indistinguishable hydroids, and vice versa; (6) the morphological variation sometimes displayed within a given taxon; (7) the scarcity of reliable taxonomic characters in various taxa; (8) the general lack of knowledge concerning the biology of these animals, including life cycles of many species. Classification of the order Athecatae Hincks, 1868, in particular is currently in a state of flux. Most authors over the past 30 years have regarded the Capitata Kühn, 1913, as the most primitive suborder of the Hydrozoa, largely following Rees (1957). Athecate classification has been extensively modified recently by Petersen (1979), Werner (1984), and Bouillon (1985). Following the last two authors, families of the suborder Filifera Kühn, 1913, are discussed first here. Yet it is unlikely that a stable classification, accurately reflecting relationships within the Athecatae, has been achieved by the traditional approaches used in studies to date. A re-examination of relationships within athecate hydroids and their medusae, especially using methods of phylogenetic systematics (Wiley, 1981), is greatly needed. The only such study within the Hydrozoa up to now is that by Cairns (1984) for stylasterids. The arrangement of families adopted here, somewhat modified from Werner (1984), is recognized as unsatisfactory. Unfortunately, no demonstrably superior classification exists at present.

The known range given here is based on reported occurrences at Bermuda, and elsewhere in the Atlantic, Pacific, and Indian oceans. In most cases, only one significant record has been cited to document occurrences outside Bermuda.

\section{Materials and Methods}

Hydroids were collected during six field trips to the Bermuda Islands, on the following dates: 1-22 September 1977. 26 February-10 March 1982, 17 July-6 August 1982, 15 June-13 July 1983, 20 September-11 October 1984, and 24 September-8 October 1986. Specimens were also obtained on 23-24 May 1979 during a two-day vitcation cruise to the islands. Most collections were made by snorkelling, although scuba gear was used on occasional dives. Collecting efforts were concentrated in shallowwater areas of the northeastern half of Bermuda, especially in Flatts Inlet, Castle Harbour, Harrington Sound, and Whalebone Bay (Fig. 1), and only those hydroids taken in depths of $0-100 \mathrm{~m}$ are included in this report. Intensive sampling was undertaken around ledges, bridges, pilings. floats, and moorings; in grass beds; and in ponds and caves. Considerable time was spent searching beaches for stranded specimens of the neustonic hydroids Porpita and Velella. Large quantities of pelagic Sargassum were collected and examined for attached hydroids during each field trip.

Collections at depths of $60-100 \mathrm{~m}$ in offshore waters south of Castle Harbour were made by dredging from the M/V Northstar (3 September 1977), R/V Culver (1 July 1983), and R/V Weatherbird (27 September 1984). Dredg- 


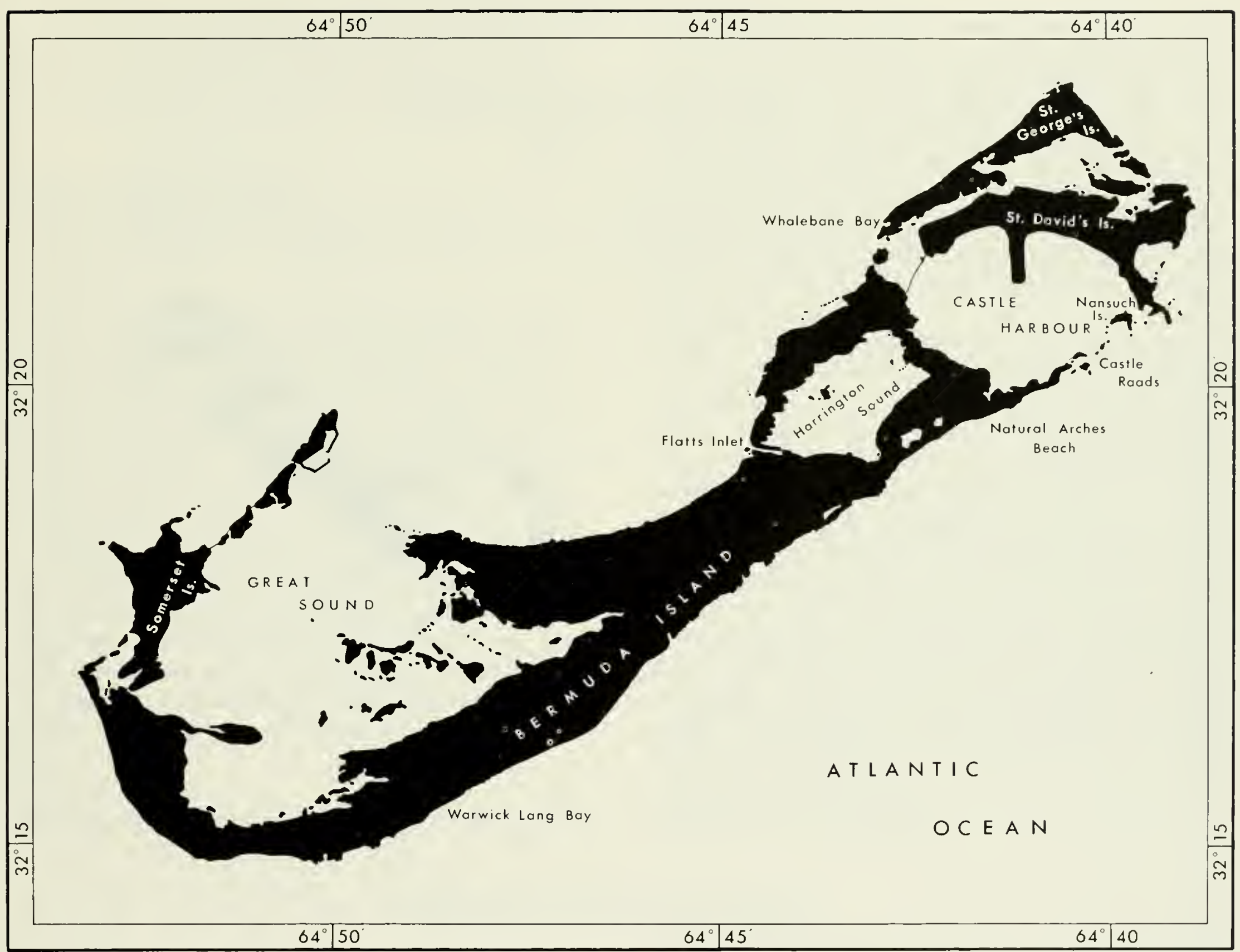

FIG. 1. The Bermuda Islands.

ing in $75 \mathrm{~m}$ of water on Challenger Bank. southwest of Bermuda (Fig. 2), was undertaken on 3 October 1984 aboard R/V BBS II; on the return cruise from Challenger Bank, a $10-$ minute plankton tow was made $6 \mathrm{~km}$ offshore from Gibbs Hill lighthouse with a plankton net $1 \mathrm{~m}$ in diameter.

Hydroids in reference collections at the Bermuda Biological Station were examined. Among these were specimens from (1) buoy chains, collected by Dr John Markham and colleagues between 5 Oetober and 23 December 1976; (2) waters south of Castle Harbour in 60-100 m, collected by Dr Markham using a dredge aboard M/V Northstar on 6 August and 27 August 1977; (3) the Castle Harbour area. collected by Prof. H. Mergner on 22 and 24 June 1967; (4) the Castle Harbour area, collected by Dr H. Thiel on 3-4 August 1974; (5) Argus Tower on Plantagenet Bank (Fig. 2), collected by Dr W. Sterrer on 23 April 1976; (6) the wreck Pelinaion off St David's Island, collected by
Dr W. Sterrer on 18 August 1974; (7) Castle Harbour. collected by H. E. Lehman in June 1966; (8) surveys of Bermudian caves, collected by Dr T. Iliffe during the summer of 1982.

Specimens collected during this investigation have been deposited in the Department of Invertebrate Zoology, Royal Ontario Museum (ROMIZ). All descriptions and illustrations herein are from Bermuda material, as indicated. except for a paratype of Coryne sargassicola from the Gulf Stream off New York City.

As complete a synonymy as possible has been given for each taxon, although many of the lists may be less than exhaustive. Virtually all of the listed synonyms have been verified by examination of cited references.

Nematocysts were examined in preserved material by compressing pieces of tissuc, or entire individuals of minute specimens, between a slide and coverslip. Occasion- 
ally, materials were treated with a 5 per cent solution of sodium hypochlorite for 15 to 45 seconds and rinsed in fresh water prior to slide preparation. All observations were made by brightfield microscopy. Nematocyst categories were identified based on Weill's (1934) classifica- tion. Length and width measurements were made on undischarged and horizontally oriented nematocysts using an ocular micrometer. At least 10 nematocysts of each type in each species were measured in determining size ranges.

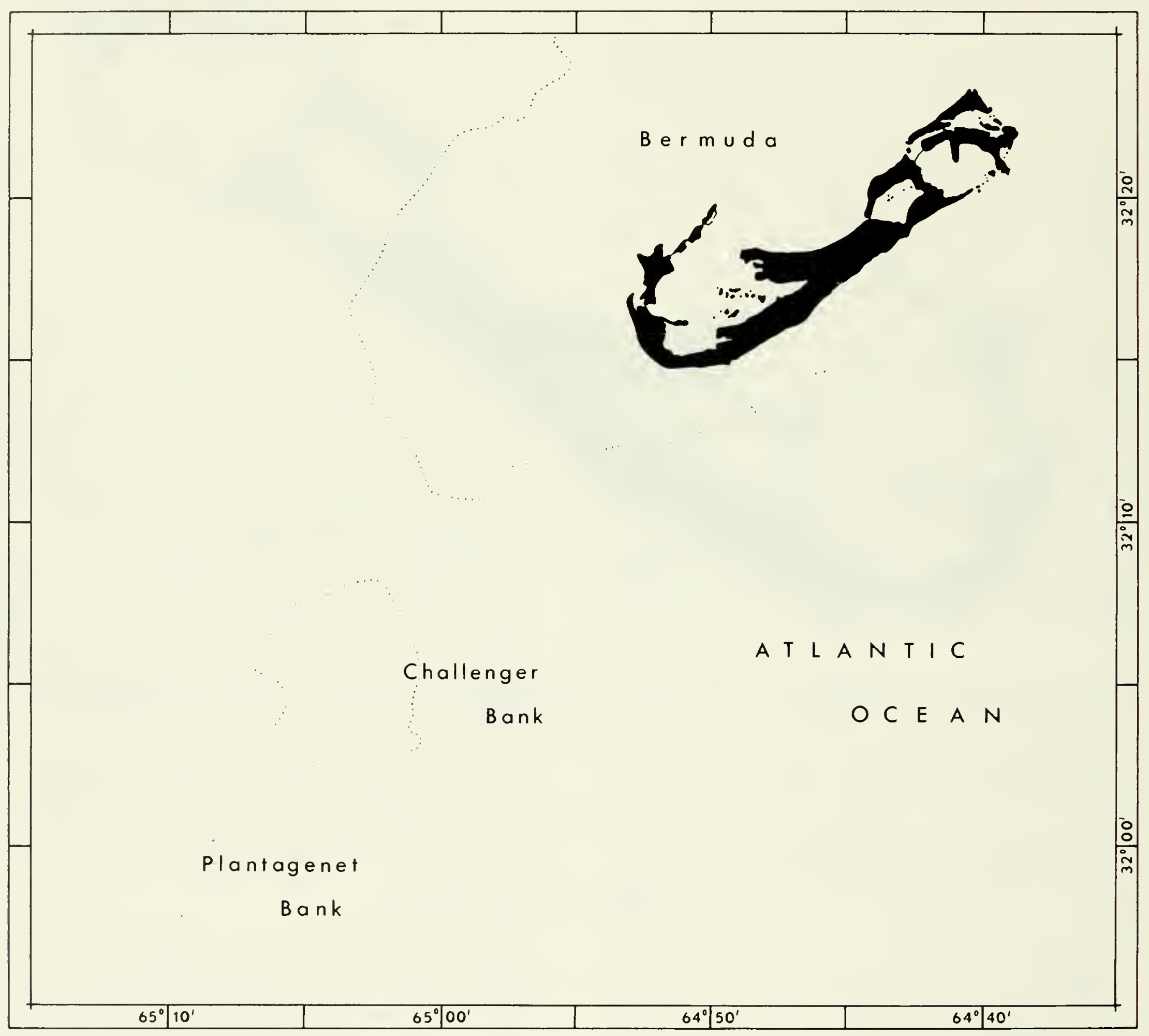

Fig. 2. Bermuda, Challenger Bank, and Plantagenet Bank. 


\title{
Systematic Account
}

\author{
Family Clavidae McCrady, 1859a
}

Clavidae McCrady, 1859a:123.

Turridae Allman, 1872:259.

Cordylophorinae von Lendenfeld, 1885a:221.

\section{DIAGNOSIS}

Hydroids solitary or colonial. Colonies stolonal or erect, arising from a creeping hydrorhiza; growth in erect colonies monopodial with terminal hydranths. Perisarc soft or firm, investing hydrorhiza only or covering both hydrorhiza and hydrocaulus, usually terminating at base of hydranth. Hydranths elongate, clavate to fusiform, with scattered filiform tentacles. Hypostome conical. Nematophores present or absent.

Gonophores fixed sporosacs or free medusae, arising from hydrorhiza, hydrocaulus, branches, pedicels, or entire or reduced hydranths. Medusa bell-shaped with short manubrium; mouth of medusa surrounded by four lips, margins of lips with clusters of nematocysts. Radial canals four. Marginal tentacles solitary, numerous in adult. Ocelli present. Gonads on interradial walls of manubrium.

\section{REMARKS}

The family name Turridae was constituted by Allman (1872) for clavid-like hydroids having medusiform gonophores. Taxa referred by Allman to the nominal family are now generally included in the Clavidae McCrady, 1859a. The identity of Turris Lesson, 1843, type genus of the Turridae, is discussed below under Turritopsis nutricula McCrady, 1859b.

The family Clavidae has been used as a catch-all group for a seemingly rather disparate assemblage of hydroids having scattered filiform tentacles on the hydranth. Differences among taxa within the Clavidae are sufficiently large to warrant recognition of several subfamilies at least. In addition to the nominotypical subfamily Clavinae McCrady, 1859a, the Corydendriinae, subf. nov., is recognized below. Earlier, von Lendenfeld (1885a) founded the subfamily Cordylophorinae, including in it the genera Cordylophora Allman, 1844, and Merona Norman, 1865. Of these two, only Cordylophora should be retained in the Cordylophorinae, in my opinion. One or more additional new subfamilies should be established for clavid genera not represented in Bermuda, but doing so is beyond the scope of this report.

Bouillon (1985) included 11 genera of hydroids and hydromedusae in this family.

\section{Subfamily Corydendriinae, subf. nov.}

\section{DIAGNOSIS}

Clavid hydroids with stolonal or erect colonies; branches of erect colonies adnate to hydrocaulus for a varying distance basally. Hydranths elongate, more or less cylindrical, not polymorphic; tentacles filiform, scattered over much of hydranth. Nematophores absent.

Gonophores fixed sporosacs or free medusae, arising from hydrorhiza, hydrocaulus, branches, or pedicels, but not from hydranths.

\section{REMARKS}

Hydroids of the Corydendriinae, subf. nov., differ from the Clavinae McCrady, 1859a, in having cylindrical instead of club-shaped hydranths, tentacles scattered over much of the hydranth rather than restricted to a bulbous region distally, and gonophores borne on hydrorhiza, stem, or branches instead of on the hydranth. Unlike on the Cordylophorinae von Lendenfeld, 1885a, the branches are adnate for some distance at their origin rather than becoming immediately free, and the hydranths are elongate and tubular rather than spindle-shaped to vasiform. The subfamily Corydendriinac, as defined here, encompasses the genera Corydendrium van Beneden, 1844a, Turritopsis McCrady, 1859b, and Rhizodendrium, gen. nov. It is possible that the poorly known genus Tubiclava Allınan, 1863 , if it is valid, belongs in this group. Merona Norman, 1865. having polymorphic hydranths and nematophores, is excluded; without doubt it should be referred to another new subfamily within the Clavidae.

\section{Genus Corydendrium van Beneden, 1844a}

Corydendrium van Beneden, 1844a:313.

Soleniopsis Ritchie, 1908:494.

\section{DIAGNOSIS}

Clavid hydroids with erect, irregularly branched colonies; hydrocaulus polysiphonic. Branches adnate to hydrocaulus, or to other branches, over part or all of their lengths. Perisarc firm, terminating near hydranth base. Hydranths elongate, tubular; tentacles filiform. scattered over much of hyciranth.

Gonophores fixed sporosacs, arising as blind, clongate 
sacs of coenosarc below hydranths and within perisarcal tubes of branchlets.

\section{TYPE SPECIES}

Sermlaria parasitica Linnaeus, 1767, by monotypy.

\section{REMARKS}

L. Agassiz (1862) believed that Corydendrium van Beneden, 1844a, and Cordylophora Allman, 1844, were congeneric, and he referred both to the nominal genus Syncoryna Ehrenberg, 1834. Allman (1872) showed why neither should be referred to Syncoryna, identical with Coryne Gaertner, 1774, and argued that they represented two distinct genera. Colony form, hydranth shape, and characteristics of the gonophores are sufficiently distinctive in Corydendrium to warrant its separation from Cordylophora.

Ritchie (1908) recognized the similarities between Coryendrinm and his nominal genus Soleniopsis, but he mistakenly believed that the former produced free medusae. Stechow (1911) recognized this error and referred Soleniopsis to Corydendrium.

Kramp (1935) regarded Turritopsis McCrady, 1859b, as congeneric with Corydendrium, suggesting that hydroids of the two differed only in the type of gonophore produced. Petersen (1979) seems to have adopted this view, but both genera are recognized as valid here and in most other recent publications. Kramp himself, in later reports (e.g., Kramp, 1959, 1961, 1965, 1968), employed the name Turritopsis for the medusa.

\section{Corydendrium parasiticum (Linnaeus, 1767)}

Figs. 3, 4

Sertularia parasitica Linnaeus, 1767:1315.

Sertolara parassita-Cavolini, 1785:181; pl. 6, figs. 8-13 [incorrect subsequent spelling].

Pennaria parasitica-Goldfuss, 1820:89.

Sertulariam parasiticam-Ehrenberg, 1834:71 [incorrect subsequent spelling].

Syncoryna parasitica-Ehrenberg, 1834:71.

Corydendrium parasiticum — van Beneden, 1844b:313.

Sertularia (Syncoryne) parasitica-Frey and Leuckart, 1847:30.

Syncoryne parasitica-Allman, 1864a:352.

Clava parasiticum-Bonnevie, 1899a:9.

Clava (Corydendrium) parasiticum-Bonnevie, 1899a:39.

Soleniopsis dendriformis Ritchie, 1908:495; figs. 142, 143;

pl. 26, fig. 1.

Corydendrium sessile Ritchie, 1910a:802; pl. 76, figs. 1,2 .

Corydendrium dendriformis-Ritchie, 1910a:803.

Corydendrium dendriforme-Gravely, 1927:7; pl. 2,

fig. 2 .

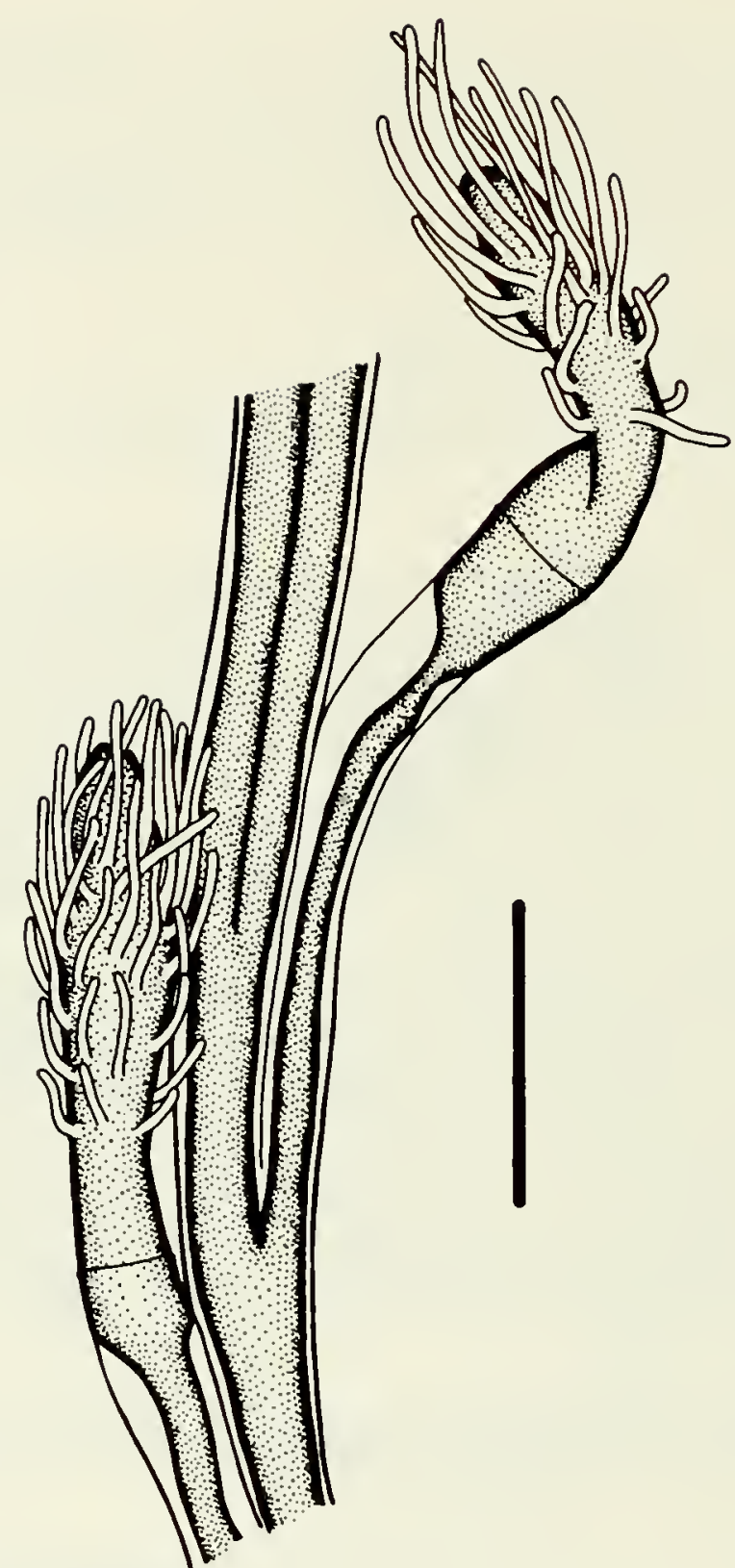

Fig. 3. Corydendrium parasiticum, part of hydrocaulus with hydranths, Romiz B 136. Scale equals $1 \mathrm{~mm}$.

Corydendrium flabellatum Fraser, 1938:11; pl. 1, figs. a,b.

Corydendrium parasticum-Wedler and Larson, 1986:71 [incorrect subsequent spelling].

\section{TYPE LOCALITY}

"Habitat in Oceano, saepe in Corallina rubente" (Linnaeus, 1767).

\section{MATERIAL EXAMINED}

Flatts Inlet, on underside of large, flat rock, $-3 \mathrm{~m}, 2$ August 1982, one colony, $2.2 \mathrm{~cm}$ high, without gonophores, ROMIZ B136. Atlantic Ocean, $2 \mathrm{~km}$ southeast of Castle Roads, on calcareous rubble, -60 to $-90 \mathrm{~m}, 3$ September 1977, one colony, $4.5 \mathrm{~cm}$ high, without hydranths and gonophores, ROMIZ B158. Harrington Sound, near Flatts Inlet bridge, on ledge near shore, $-1.5 \mathrm{~m}, 5$ March 1982, two colonies, $4 \mathrm{~cm}$ high, without gonophores, ROMIZ B 173. 


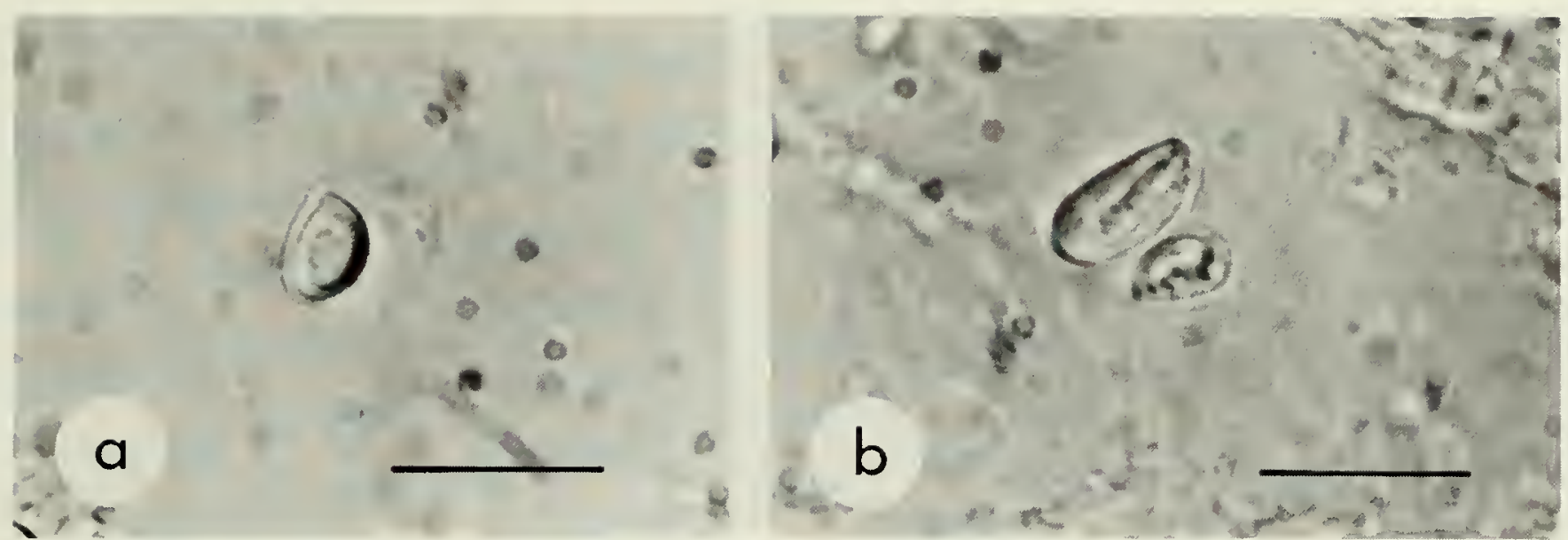

FlG. 4. Corydendrium parasiticum, nematocysts of hydranth, Romiz B158. Scales equal $10 \mu \mathrm{m}$. $a$, Desmoneme. $b$, Heterotrichous microbasic eurytele.

\section{DESCRIPTION}

Colonies erect, straggly, up to $4.5 \mathrm{~cm}$ high, arising from a creeping hydrorhiza. Hydrocaulus polysiphonic in all but very young colonies, individual tubes relatively stout, $0.45 \mathrm{~mm}$ in diameter. Branching irregular, in one or more planes, branches adnate to hydrocaulus basally, gradually curving outwards and becoming free distally; secondary branches arising in like manner from primary branches; ultimate branchlets typically alternate. Perisarc moderately thick over most of colony, becoming thin at hydranth base and terminating below tentacles, smooth or with occasional wrinkles but not annulated, clear to straw-coloured, often encrusted with detritus and silt. Hydranths cylindrical through clavate to fusiform, constricted basally below orifice of perisarc tube, up to $2.8 \mathrm{~mm}$ long from basal constriction to tip of hypostome, about $0.3-0.5 \mathrm{~mm}$ wide. Tentacles filiform, often as many as 40 or more, scattered over distal three-quarters of hydranth, proximal tentacles shorter and more slender than distal ones. Hypostome elongate, conical.

Gonophores not seen.

Nematocysts-

Hydroids: desmonemes 5.3-5.7 $\mu \mathrm{m} \times 3.7-3.8 \mu \mathrm{m}$; heterotrichous microbasic euryteles $8.2-8.4 \mu \mathrm{m} \times 3.8-$ $4.3 \mu \mathrm{m}$.

\section{REMARKS}

Ritchie (1910a) believed that Corydendrium dendriforme (Ritchie, 1908) was distinct from C. parasiticum (Linnaeus, 1767) in having (1) thicker, more definite stems; (2) branchlets arranged in a pseudopinnate fashion; and (3) the free portion of the pedicels much less elongate. Rees and Thursfield (1965) also considered $C$. dendriforme to be valid. However, the characters used to distinguish them seem variable, and Vervoort (1941) and Millard (1959a, 1975) have been followed in regarding the name $C$. dendriforme as a junior synonym of $C$. parasiticum.

Leloup (1937) regarded Corydendrium sessile Ritchie,
$1910 \mathrm{a}$, as conspecific with $C$. dendriforme, suggesting that the former was based on a young, immature colony of the latter. Its name, too, is referred to $C$. parasiticum here.

Fraser's (1938) account of Corydendrium flabellatum from the Pacific coasts of Mexico and Panama corresponds with $C$. parasiticum, and the former is regarded here as conspecific with the latter. The status of $C$. friuticosum Fraser, 1914, from the Vancouver Island region is unclear. The colony form of this hydroid appears to have resembled that of $C$. parasiticum and other nominal species of the genus, but the species was referred to Corydendrium van Beneden, 1844a, with some doubt by Fraser (1914, 1937. 1946) because its gonophores had not been observed. According to Fraser (1914), hydranths of $C$. fruticosum have 12 to 15 tentacles, far fewer than the number usually present in $C$. parasiticum. Corydendrium fruticosum merits further study to determine its affinities.

\section{KNOWN RANGE}

Bermuda: first record.

Elsewhere: western Atlantic (Wedler. 1975); eastern Atlantic (Ritchie, 1908); Indian Ocean (Millard, 1975); western Pacific (Leloup, 1937): eastern Pacific (Fraser, 1938).

\section{Genus Turritopsis McCrady, 1859b}

Clavula Wright, 1859:106.

Turritopsis McCrady, 1859b:58.

Dendroclava Weismann, 1883:26.

Turrutopsis Wedler and Larson, 1986:71 [incorrect subsequent spelling].

\section{DIAGNOSIS}

Clavid hydroids with stolonal or erect and irregularly branched colonies; hydrocaulus monosiphonic or polysiphonic. Branches adnate to hydrocaulus, or to other branches, over part of their length. Perisare firm, termi- 
nating near hydranth base. Hydranths elongate, tubular; tentacles filiform, scattered over much of hydranth calyx.

Gonophores free medusae, developing on pedicels or branches below hydranths. Medusa with eight or more simple, solitary marginal tentacles. Radial canals surrounded by mass of vacuolated cells at apex of stomach. Ocelli present.

\section{TYPE SPECIES}

Tutritopsis nutricula McCrady, 1859b, by monotypy.

\section{REMARKS}

The familiar and widely used name Turritopsis McCrady, $1859 \mathrm{~b}$, is predated by the nearly forgotten Clavula Wright, 1859. and the two are considered synonyms here, as discussed below. Although McCrady's (1859b) paper proposing the generic name Turritopsis was presented orally before a meeting of the Elliott Society of Natural History of Charleston, South Carolina, on I December 1856, the proceedings of the meeting were not published until 1859 . Only the year of publication is indicated on the cover of these proceedings. In the absence of other information, the ditte must be taken as the last day of the year [Art. 2 Ic (ii)]. Wright's (1859) account of Clavula, in the July 1859 issue of the Edinburgh New Philosophical Journal. must be interpreted as having been published first. Application will be made to the ICZN to use its plenary powers [Art. 79] to suppress the virtually unused name Clavila Wright, 1859, in favour of the well-known Turritopsis.

Russell (1953) included Turris neglecta Lesson, 1843, as questionably conspecific with Turritopsis mutricula, the type species of Turritopsis. However, he noted that Lesson's medusa was inadequately described and its identity uncertain. The genus name Turris Lesson, 1843, is regarded here as a nomen dubium. Mueller (1766) had earlier applied the name Turris to a genus of the Mollusca, but Mueller's publication has been placed on the Official Index of Rejected and Invalid Works in Zoological Nomenclature by the ICZN (Opinion 701).

\section{Turritopsis nutricula McCrady, 1859b}

Figs. 5, 6

?Turris neglecta-Forbes, 1848:23; pl. 3, figs. $2 \mathrm{a}-\mathrm{i} \mid$ medusa] [Turris neglecta Lesson, 1843, a nomen dubium].

Clavula gossii Wright, 1859:106; pl. 8, fig. 1.

Oceania (Turritopsis) mutricula McCrady, 1859b:56; pl. 4. figs. 1-10,12-15,28a; pl. 5, figs. 11,16-18,28b [medusa].

Turritopsis nutricula McCrady, 1859b:58 [medusa].

Turritopsis nutricola-L. Agassiz, 1862:347 [medusa] [incorrect subsequent spelling].

Oceania polycirrha Keferstein, 1863:26; pl. 2, figs. 1113 [medusa].

Turritopsis polynema Haeckel, 1879:66 [medusa].

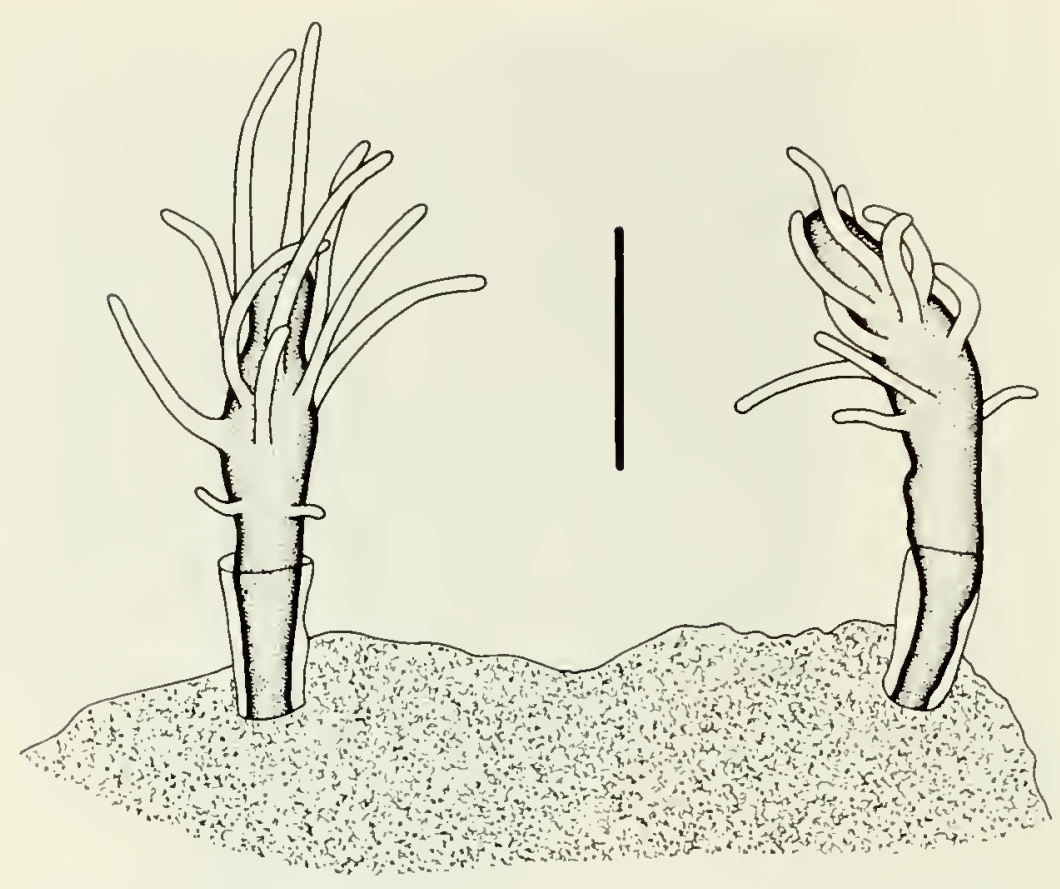

FIG. 5. Turritopsis mutricula, two hydranths arising from sponge substrate, ROMız B 172. Scale equals $0.5 \mathrm{~mm}$.

Modeeria multitentacula Fewkes, 1881:149; pl. 3, figs. 7-10 [medusa].

Modeeria nutricula-Fewkes, 1882:294; pl. 10, fig. 8 [medusa].

Modeeria (Turritopsis) nutricula-Fewkes, I883:80 [medusa].

Modeeria multitentaculata-Brooks, 1883a:144 [medusa] [incorrect subsequent spelling].

Oceania nutricula-Brooks, 1883b:465 [medusa].

Modeeria mutricola-Brooks, 1886:388 [medusa] [incorrect subsequent spelling].

Turritopsis polycirrha-Hartlaub, 1897:480; pl. 16c, fig. 2 [medusa].

Turritopsis mutricola var. pacifica Maas, 1911:14; pl. 1, figs. 6-8; pl. 2, fig. 9 [medusa] [incorrect subsequent spelling].

Corydendrium mutricula-Kramp, 1935:11.

Turrutopsis nutricula-Wedler and Larson, 1986:71 |incorrect subsequent spelling].

\section{TYPE LOCALITY}

Charleston Harbour, South Carolina, United States.

\section{MATERIAL EXAMINED}

Whalebone Bay, on sponge, - 1 m, 7 September 1977 , two colonies, $5 \mathrm{~mm}$ high, without gonophores, ROMIZ B 162. Flatts Inlet, on sponge, $-2 \mathrm{~m}, 5$ March 1982, one colony, with hydranths extending $1.5 \mathrm{~mm}$ above sponge substrate, without gonophores, ROMIZ B172.

\section{DESCRIPTION}

Colonies erect, with hydrorhiza and much of hydrocaulus embedded in sponge, sparingly and irregularly branched, reaching $5 \mathrm{~mm}$ high. Hydrocaulus monosiphonic, branches 

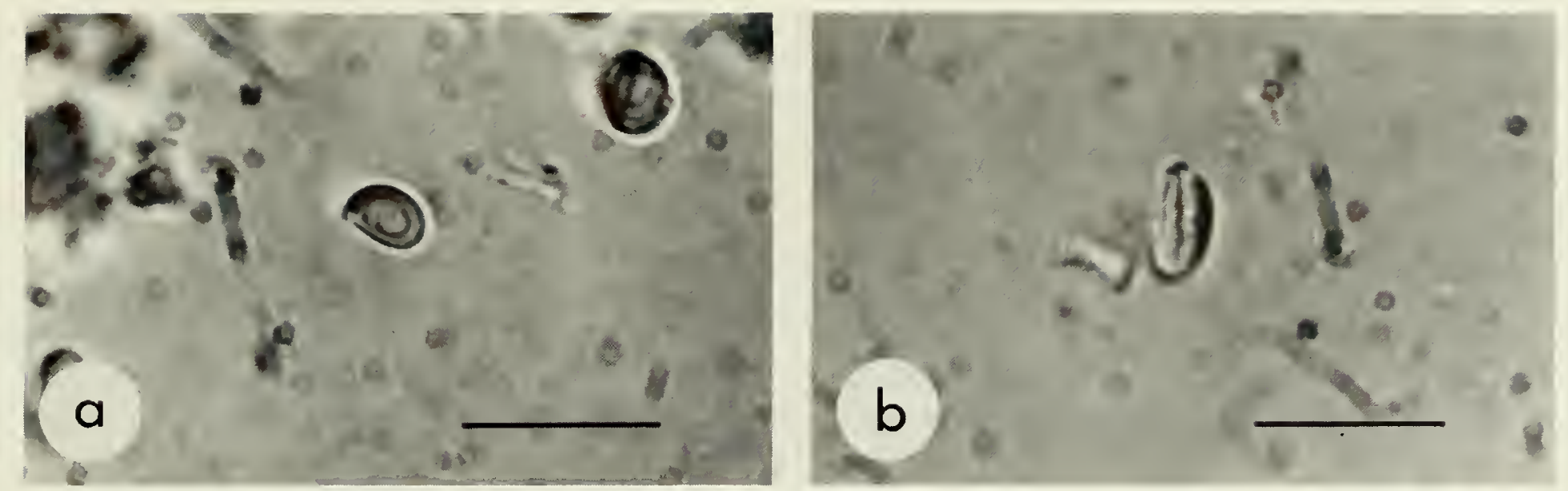

FlG. 6. Turritopsis nutricula, nematocysts of hydranth, Romiz B 172. Scales equal $10 \mu \mathrm{m} . a$, Desmoneme.

$b$, Heterotrichous microbasic eurytele.

adnate to hydrocaulus at their origin, curved outwards and becoming free distally; hydrocaulus and branches slender basally, $0.12 \mathrm{~mm}$ wide, gradually expanding in diameter distally, reaching $0.23 \mathrm{~mm}$ wide at base of hydranth. Perisare moderately thick, clear to straw-coloured, with fine longitudinal creases and occasional wrinkles but no annulations, terminating below tentacles on hydranth base. Hydranths fusiform, reaching $0.9 \mathrm{~mm}$ long from base to tip, $0.2 \mathrm{~mm}$ wide. Tentacles filiform, 12 to 20 in number; about 4 in an irregular whorl distally, remainder scattered over distal two-thirds to three-quarters of hydranth, those at proximal end shorter and more slender than those at distal end. Hypostome elongate, conical.

Gonophores not seen.

Nematocysts-

Hydroids: desmonemes $4.6-4.8 \mu \mathrm{m} \times 2.8-3.1 \mu \mathrm{m}$; heterotrichous microbasic euryteles (small) $6.5-6.8 \mu \mathrm{m}$ $\times 3.1-3.3 \mu \mathrm{m}$.

\section{REMARKS}

Both hydroid and medusa stages of this species have long been known as Turritopsis nutricula McCrady, 1859b, but this binomen is actually predated by the virtually forgotten name Clavula gossii Wright, 1859. This nomenclatural problem arises in part from Wright's application of a separate name to the hydroid of a medusa he believed was conspecific with Turris neglecta Lesson, 1843. His contemporaries (e.g., Allman, 1864a, 1872; Hincks, 1868) realized that this contravened nomenclatural principles, and the name $C$. gossii was included in the synonymy of $T$. neglecta in their monographs. However, $T$. neglecta is now generally considered to be a nomen dubium. According to Russell (1953), Lesson's (1843) description of the medusa was inadequate for positive identification. Russell (1953) believed that the medusa described by Wright (1859) was identical with $T$. mutricula, and he included the name $C$. gossii as its junior synonym. This interpretation of relative priority was based on the widespread but mistaken belief (e.g., see A. Agassiz, 1865; Mayer, 1910;
Fraser, 1944; Russell, 1953; Kramp, 1961; Vervoort, 1968; Millard, 1975) that McCrady's (1859b) original description of T. mutricula was published in 1856, as discussed earlier (see p. 8). Clavula gossii has not been used as a senior synonym since it was instituted by Wright (1859), to my knowledge. Upon completion of this study, application will be made to the ICZN to use its plenary powers [Art. 79] to suppress the name Clavula gossii Wright, 1859, in favour of Turritopsis mutricula McCrady, $1859 \mathrm{~b}$.

1 have followed Mayer (1910) and Russell (1953) in regarding Oceania polycirrha Keferstein, 1863, Turritopsis polynema Haeckel, 1879, and Modeeria multitentacula Fewkes, 1881, as conspecific with this species.

Most authors have adopted the view of Stechow (1923a) that Turritopsis dolirnii (Weismann, 1883) is conspecific with $T$. mutricula. Hydroids of the two appear to differ in both colony form and habitat. Unlike colonies of $T$. nutricula, which are small with a monosiphonic hydrocaulus and usually found in shallow water, hydroids of $T$. dohtrnii are larger with a polysiphonic hydrocaulus and known from deeper waters. Numerous specimens of $T$. mutricula have been observed from shallow-water habitats of Virginia (Calder, 1971) and South Carolina, including the type locality of Charleston Harbour (Calder and Hester, 1978). None of these hydroids were more than a few millimetres in height, and none had polysiphonic stems like $T$. dohrnii. Specimens of $T$. mutricula from nearshore waters of Bermuda resembled those examined from the American east coast in colony form. Both species are recognized as valid here because conclusive evidence that differences in colony form in the two may be environmentally induced is lacking. Young medusae have been described from both species, but a critical comparison of the two has not been made. The adult medusa of $T$. dohrnii is apparently unknown. Specimens identified as T. dohmii (RoMIz BI39) were found on a brachyuran crab collected at a depth of $256 \mathrm{~m}$ off Castle Roads, Bermuda, during this study. However, the species has been excluded from this report. which includes hydroids from the upper $100 \mathrm{~m}$ only. 
Turritopsis fascicularis Fraser, 1943b, collected from a depth of 118 fathoms $(216 \mathrm{~m}$ ) off Florida, appears to be identical in most respects with descriptions of $T$. dohrnii, and is regarded here as conspecific with the latter rather than with $T$. mutricula.

McCrady (1859b) mistook the parasitic actinula larva of the narcomedusa Cunina octonaria McCrady, 1859a, a frequent parasite on the medusa stage of Turritopsis nutricula, for the hydroid of this species. Excellent descriptions and illustrations of the hydroids and young medusae of T. nutricula were given by Brooks (1886).

\section{KNOWN RANGE}

Bermuda: Castle Harbour, medusa stage (Fewkes, 1883); in shallow inshore waters and on buoy chains (Calder, 1986).

Elsewhere: western Atlantic (Fraser, 1944); eastern Atlantic (Russell, 1953); Indian Ocean (Millard, 1975); western Pacific (Ralph. 1953); eastern Pacific (Fraser, 1948).

\section{Genus Rhizodendrium, gen. nov.}

\section{DIAGNOSIS}

Clavid hydroids with creeping hydrorhiza and sessile, elongate hydranths. Hydranths invested with thin perisarc proximally, occasionally forming a basal collar; tentacles filiform, as many as 20 or more, arranged in a more or less regular whorl around mouth, scattered or in several irregular whorls proximally, those of distal end longer and stouter than those proximally. Hypostome short, domeshaped.

Gonophores fixed sporosacs, borne on hydrorhiza, spherical where known.

\section{TYPE SPECIES}

Rhizodendrium sterreri, sp. nov., designated herein.

\section{ETYMOLOGY}

The name is a combination of parts of the names Rhizogeton and Corydendrium, and is derived from the Greek words rhiza (root) and dendron (tree). The gender of the name is neuter.

\section{REMARKS}

Rhizodendrium, gen. nov., resembles Rhizogeton L. Agassiz, 1862, a genus established to accommodate the hydroid R. fusiformis L. Agassiz, 1862, from tide pools on the Massachusetts coast. L. Agassiz ( 1862) observed that Rhizogeton was similar to Clava Gmelin, 1790, but differed in having a thin covering of perisarc over the proximal part of the hydranth, a different hydranth shape, and gonophores on the hydrorhiza instead of the hydranth. Examination of type material of the type species, $R$. $f u$ - siformis (MCZ 52), confirmed Agassiz's original description of Rhizogeton in most respects, although the specimens were in rather poor condition. Nevertheless, it was apparent from this examination that Rhizodendrium can be held distinct from Rhizogeton, on the following characters. The hypostome is short and dome-shaped, instead of very elongate and conical. Tentacles number as many as 20 or more, instead of a maximum of 10 . The tentacles are arranged in an oral whorl distally, and sometimes occur in more or less regular whorls elsewhere on the hydranth, instead of being decidedly scattered.

The shape of the hydranth in Rhizodendrium is much like that of Turritopsis McCrady, 1859b, and somewhat less like Corydendrium van Beneden, 1844a. The colony form is strictly stolonal, unlike that of Turritopsis and Corydendrium, and the gonophores arise from the stolon rather than from branchlets or pedicels. In Tubiclava Allman, 1863, gonophores were believed to arise in dense clusters from the hydranth, as in Clava (Allman, 1863, 1872), and not from the hydrorhiza, as in Rhizodendrium.

Two nominal species referred to Rhizogeton- $R$. nudus Broch, 1909, from Spitzbergen and $R$. ezoense Yamada, 1964, from Japan-are transferred here to Rhizodendrium. The only species thus remaining in Rhizogeton is $R$. fllsiformis. Rhizogeton nematophorus Antsulevich and Polteva, 1986, from the USSR is a polymorphic species with nematophores, and seems sufficiently distinct to be recognized as a new genus.

Gonophores have not been observed in the type species of Rhizodendrium. However, those of $R$. nudum and $R$. ezoense are spherical rather than fusiform, as in Rhizogeton.

\section{Rhizodendrium sterreri, sp. nov.}

Figs. 7, 8

\section{MATERIAL EXAMINED}

Holotype: Whalebone Bay, on pelagic Sargassum, 2 September 1977, one colony, $2 \mathrm{~mm}$ high, without gonophores, RomIz B150. Paratype: Whalebone Bay, on pelagic Sargassum, 2 September 1977, one colony, $2 \mathrm{~mm}$ high, without gonophores, ROMIZ B305.

\section{DESCRIPTION}

Colonies stolonal, with a creeping reticular hydrorhiza bearing sessile hydranths. Perisarc smooth or wrinkled, moderately thin on hydrorhiza, extending up $1 \mathrm{~mm}$ or more over base of hydranth or restricted to little more than a short collar between hydranth and hydrorhiza. Hydranths elongate, cylindrical, up to $2.0 \mathrm{~mm}$ long, $0.3 \mathrm{~mm}$ wide, with as many as 20 or more tentacles. Tentacles filiform, 4 to 6 in an irregular whorl distally, remainder scattered over distal two-thirds to three-quarters of hydranth, those at distal end longer and stouter than those proximally. 


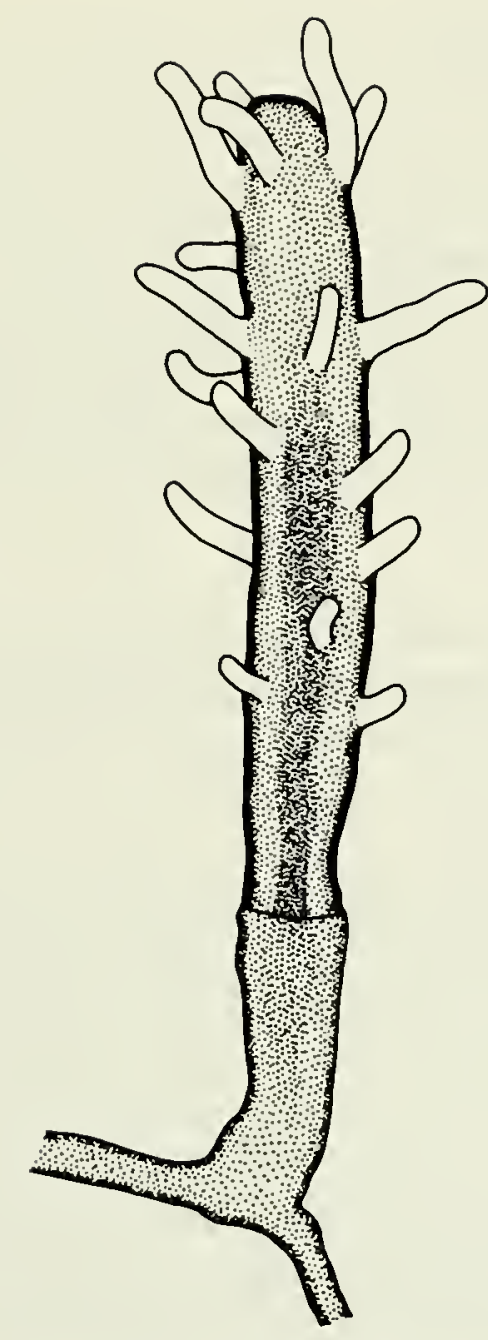

FiG. 7. Rhizodendrium sterreri, sp. nov., hydranth from holotype colony, ROMiz B 150 . Scale equals $0.5 \mathrm{~mm}$.
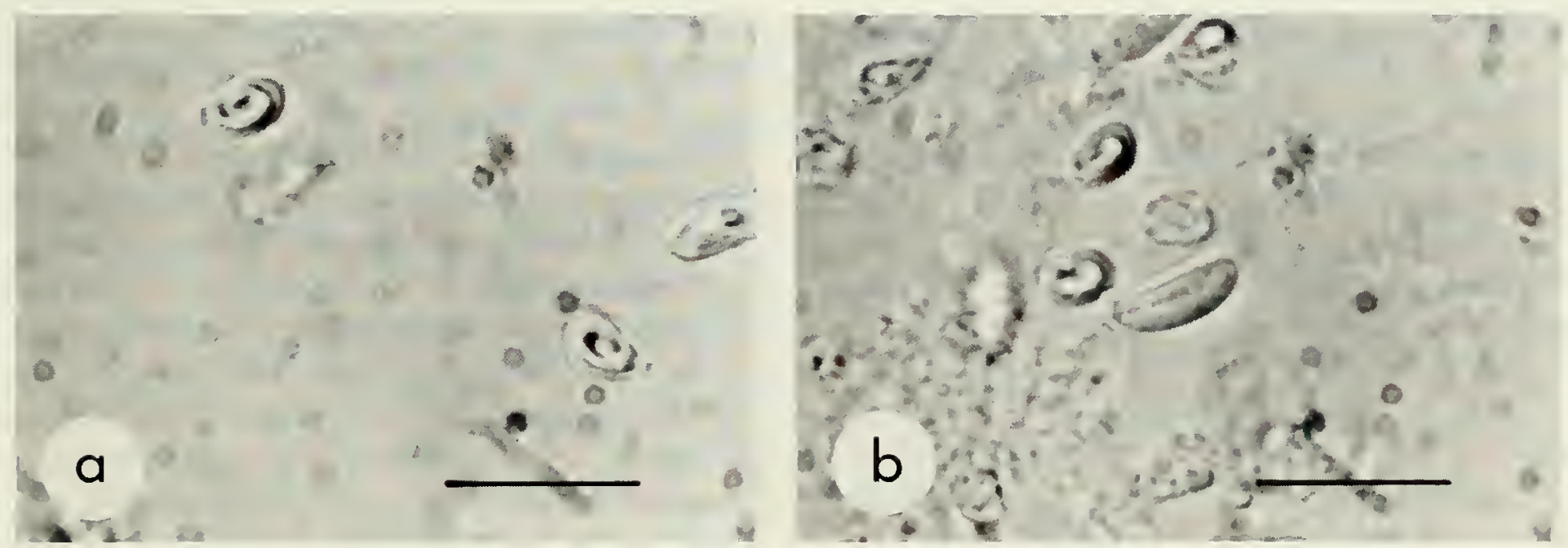

FiG. 8. Rhizodendrium sterreri, sp. nov., nematocysts of hydranth of holotype colony, Romiz B150. Scales equal $10 \mu \mathrm{m}$. $a$, Desmonemes. $b$, Heterotrichous microbasic curytele.

Hypostome dome-shaped.

Gonophores lacking.

Nematocysts-

Hydroids: desmonemes 4.6-5.2 $\mu \mathrm{m} \times 2.8-3.1 \mu \mathrm{m}$; heterotrichous microbasic euryteles $6.6-7.6 \mu \mathrm{m} \times 2.6-$ $2.9 \mu \mathrm{m}$.

\section{REMARKS}

Hydranths of Rhizodendrium sterreri, sp. nov., are distinct from L. Agassiz's (1862) description and illustrations of Rhizogeton fusiformis in having an irregular oral whorl of four to six tentacles instead of widely scattered distal ten- tacles. They also differ from those of $R$. fusiformis in being much smaller, in possessing more tentacles, and in having longer and stouter tentacles at the distal than at the proximal end.

Rhizodendrium sterreri is very similar to descriptions of its two congeners, $R$. mudum (Broch, 1909) and $R$. ezoense (Yamada, 1964), in hydranth shape and size, as well as in tentacle number, size, and arrangement. However, in $R$. sterreri the base of the hydranth is sheathed in perisare, as is obvious when the soft tissues are dissolved in sodium hypochlorite, whereas perisare is reportedly athsent from the base in $R$. nudum (Broch, 1909: Dons, 1913). 
Hydranths of $R$. stereri appear to be smaller than those of $R$. ezoense. Nematocyst data exist only from $R$. sterreri, but cnidome and nematocyst size are unlikely to differ much in these hydroids.

Rhizodendrium nudum has been reported several times from warn-water localities, but the records seem questionable on zoogeographic grounds. Ritchie (1910b) identilied a hydroid from the Christmas Islinds in the Indian Ocean as "Rhizogeton mudum Broch (?)," and indicated that his specimens lacked perisare at the base of the hydranth. Rees and Thursfield (1965) expressed some doubt that Ritchie's specimens were identical with $R$. mudum, and suggested that they might represent a juvenile colony of another species. Mammen (1963) relerred specimens from south India to $R$. mudum, but noted that they possibly belonged to another species. Millard and Bouillon (1974) reported $R$. nudum from Mozambique, and stated that their record confirmed the existence of the species in the Indian Ocean. Their hydroids, unlike those of $R$. nudum described by Broch (1909), had a collar of perisarc at the base of the hydranth. Some, if not all, of these records may be based on specimens of $R$. sterreri.

In a study of the hydroids on pelagic Sargassum in the western Atlantic, Burkenroad (in Parr, 1939) mentioned finding a hydroid resembling the genus Clav'a Gmelin. 1790. It seems highly probable that it was $R$. sterreri.

\section{ETYMOLOGY}

The species is named after Dr Wolfgang Sterrer, former director of the Bermuda Biological Station, who provided the initial stimulus for this study.

\section{KNOWN RANGE}

Known only from the type locality.

\section{Family Bougainvilliidae Lütken, 1850}

Bougainvilleae Lütken, 1850:29 (emended to Bougainvilliidae by Allman, 1876).

Hippocrenidae McCrady, 1859a:158.

Nemopsidae L. Agassiz, 1862:345.

Dicorynidae Allman, 1864a:366.

Atractylidae Hincks, 1868:87.

Bimeridae Allman, 1872:294 (emended to Bimeriidae by Torrey, 1902).

Margelidae Haeckel, 1879:68.

Lizusidae Haeckel, 1879:80.

Thamnostomidae Haeckel, 1879:84.

Pachycordylini Cockerell, 1911:77.

Lizziinae Russell, 1953:144.

Clavopsellidae Thiel, 1962:249.

\section{DIAGNOSIS}

Hydroid colonies stolonal or erect, arising from a creeping hydrorhiza; growth monopodial with terminal hydranths. Perisare on hydrorhiza and hydrocaulus of varied thickness, terminating at base of hydranth or extending over hydranth as a thin, lilmy pseudohydrotheca. Hydranths cylindrical through fusiform to vasiform, with one or more whorls of filiform tentacles beneath conical to nipple-shaped hypostome.

Gonophores fixed sporosacs or free medusae, borne on hydrorhiza, hydrocaulus, branches, and pedicels, or on entire or reduced hydranths. Medusac bell-shaped with short manubrium; mouth circular; oral tentacles simple or dichotomously branched, inserted above mouth. Radial canals four. Marginal tentacles either solitary or in clusters, borne on 4,8 , or 16 tentacle bulbs. Ocelli present or absent. Gonads on manubrium, either forming a continuous ring or on interradial, adradial, or perradial axes.

\section{REMARKS}

Characters of hydroids belonging to the Bougainvilliidae Lütken. 1850, have recently been reviewed by Millard (1975). She noted (1975:7J) that difficulties may be encountered when drawing dividing lines between hydroids of the Clavidae McCrady, 1859a, Hydractiniidae L. Agassiz, 1862, Eudendriidae L. Agassiz, 1862, and Bougainvilliidae. Medusae of the Bougainvilliidae have a number of characteristics, including the presence of oral tentacles. in common with those of the Cytaeididae L. Agassiz, 1862, and Russelliidae Kramp, 1957. Because of these similarities, Petersen (1979) placed the three families together in the superfamily Bougainvillioidea Lütken, 1850.

The family Bougainvilliidae, as currently classified, includes a seemingly disparate assemblage of hydroids and medusae. Russell (1953) recognized three subfamilies, the Bougainvilliinae Lütken, 1850, Lizziinae Russell, 1953. and Thamnostominae Haeckel, 1879, within the group. Four subfamilies are distinguished here among the bougainvilliids of Bermuda. In addition to the Bougainvilliinae, Bimeriinae Allman, 1872, and Pachycordylinae Cockerell, 1911, a new subfamily is recognized and defined, the Rhizorhagiinae. The subfamily Bimeriinae, as used here, is roughly equivalent in scope to the Thamnostominae as defined by Russell (1953). Neither hydroids nor medusae of the Lizziinae have been reported from Bermuda.

According to Haeckel (1879), the family-group names Margelidae, Lizusidae, and Thamnostomidae were first used in his 1877 manuscript "Prodromus Syst. Medusen." However, this was an unpublished document (Kramp. 1961:400), and the three names were not published (Art 81 until the appearance of the later work (Haeckel, 1879). 


\section{Subfamily Pachycordylinae Cockerell, 1911}

\section{DIAGNOSIS}

Bougainvilliid hydroids with perisare terminating at base of hydranth. Hydranths club-shaped through spindle-shaped to amphora-shaped; hypostome dome-shaped; tentacles in two or more close whorls.

Gonophores, where known, fixed sporosacs or free but sometimes degenerate medusae.

\section{REMARKS}

Whereas hydroids of the subfamily Bougainvilliinae Lütken, 1850, have tentacles arranged more or less in a single whorl on the hydranth, representatives of the tribe Pachycordylini Cockerell, 1911, herein elevated to the rank of subfamily, have tentacles in two or more whorls. Often these whorls are rather indistinct, and the tentacles may be essentially scattered. Nevertheless, the tentacles are restricted to a relatively narrow band on the hydranth and are thereby distinguishable from hydroids of the family Clavidae McCrady, 1859a.

Thiel (1962) established the nominal family Clavopsellidae for Clavopsella Stechow, 1919, and Balella Stechow, 1919, but Stechow (1922) had earlier constituted the family name Balellidae for the latter genus. Nutting (1905) applied the name Tubidendridae to the Balellidae, but this name is not available because it was not based on a name then valid for a contained genus [Art. I If (i)(1)]. Little is known about the medusa stages of either of these two genera. All of the species heretofore included in Clavopsella possess fixed gonophores or degenerate medusae. Jäderholm (1919) observed medusa buds in Balella mirabilis (Nutting, 1905), but was unable to provide information beyond size and presence of short marginal tentacles. Balella is regarded here as closer to the Clavidae than to the Bougainvilliidae because tentacles are present on the proximal as well as on the distal part of the hydranth. Accordingly, the family Balellidae is recognized here as a valid taxon. The nominal genus Clavopsella is regarded as a junior synonym of Pachycordyle Weismann, 1883. in this report, and the name Pachycordylinae has priority over Clavopsellinae.

The affinities of the genus Silhowetta Millard and Bouillon, 1973, are uncertain, but it has been included here in the Pachycordylinae because of the scattered arrangement of the tentacles and the peculiar domelike shape of the hypostome.

Representatives of the Pachycordylinae appear intermediate between bougainvilliids and clavids, but they are retained in the Bougainvilliidae here based on characteristics of the medusa of Silhouetta. Medusa buds of Silholuetta uvacarpa Millard and Bouillon, 1973, were described as being "without doubt" bougainvilliid in character by Millard and Bouillon (1973, 1975).
Genus Millardiana Wedler and Larson, 1986

Millardiana Wedler and Larson, 1986:90.

\section{DIAGNOSIS}

Hydroid colonies mostly stolonal, with perisarc terminating at hydranth base. Hydranth thick, clavate; tentacles filiform, scattered around distal end of hydranth.

Gonophores sporosacs, borne on gonozooids beneath whorl of four to five tentacles.

\section{TYPE SPECIES}

Millardiana longitentaculata Wedler and Larson, 1986. by monotypy.

\section{REMARKS}

Millardiana was established by Wedler and Larson (1986) for a hydroid resembling Pachycordyle Weismann, I883. but differing from that genus in having gonophores on gonozooids with four to five tentacles instead of zooids with the normal complement of tentacles. They referred the genus to the family Bougainvilliidae Lütken, 1850. It is tentatively referred here to the Pachycordylinae Cockerell, 1911, although the presence of gonozooids is anomalous. Millardiana is a monotypic genus.

\section{Millardiana longitentaculata Wedler and Larson, 1986}

Figs. 9, 10

Millardiana longitentaculata Wedler and Larson, 1986:90; figs. 7Ba,b; pl. 1, fig. 8 .

\section{TYPE LOCALITY}

La Parguera, Puerto Rico.

\section{MATERIAL EXAMINED}

Green Bay, Harrington Sound, on shells of Cerithium litterailum from Cladophora bed, $-2.5 \mathrm{~m}, 21$ September 1984, colonies without gonophores on four shells, ROMIZ B371.

\section{DESCRIPTION}

Colonies stolonal, with hydrorhiza adhering to gastropod shells. Pedicels very short, each bearing a terminal hydranth. Perisarc thin, smooth or slightly wrinkled, terminating at base of hydranth; pseudohydrotheca absent. Hydranths clavate to ovate to nearly fusiform, reaching $1.2 \mathrm{~mm}$ long, $0.34 \mathrm{~mm}$ wide at widest point, distal end with about 10 to $25 \mathrm{long}$, filiform tentacles in two to three close whorls, those of one whorl more or less alternating with those of adjacent whorls, proximal tentacles often 


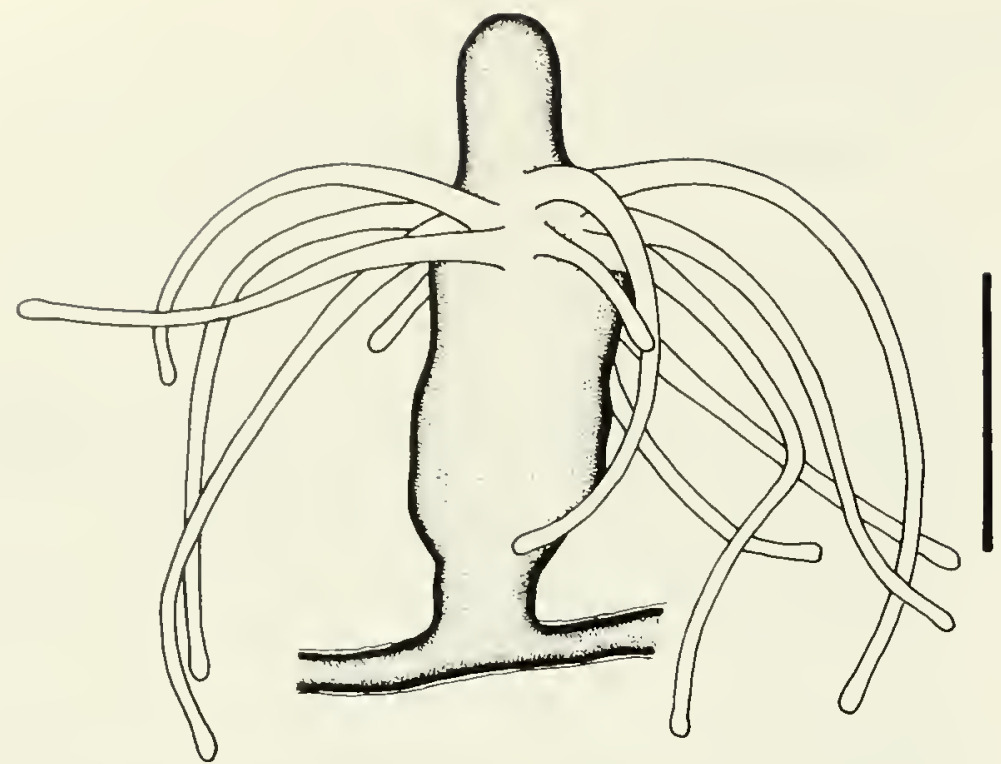

Fig. 9. Millardiana longitentaculata, hydranth, ROMIZ B371. Scale equals $0.5 \mathrm{~mm}$.
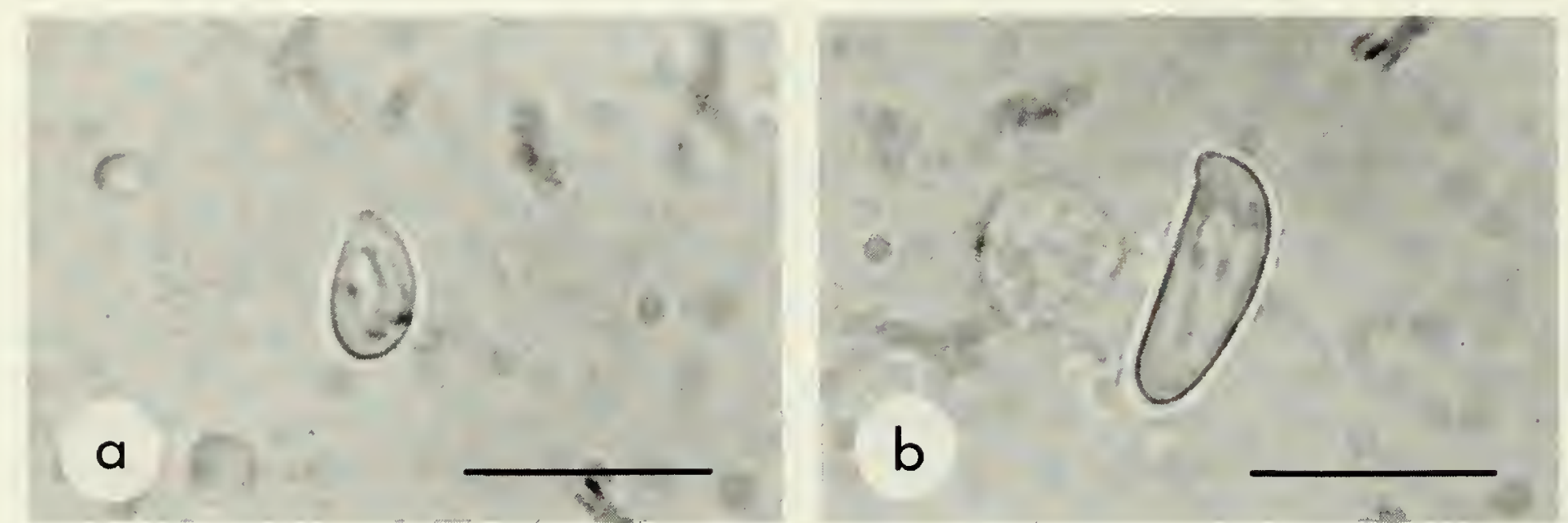

FIG. 10. Millardiana longitentaculata, nematocysts of hydranth, Romiz B371. Scales equal $10 \mu \mathrm{m} . a$, Desmoneme. $b$, Heterotrichous microbasic eurytele.

smaller than distal ones. Hypostome prominent, extensible, and proboscis-like. Colour of hydranth deep red in live material.

Gonophores not seen.

Nematocysts-

Hydroids: desmonemes $5.6-6.4 \mu \mathrm{m} \times 3.4-3.8 \mu \mathrm{m}$; heterotrichous microbasic euryteles 7.6-10.4 $\mu \mathrm{m} \times 2.8$ $3.8 \mu \mathrm{m}$.

\section{REMARKS}

Although superficially similar in colony form to Pachycordyle napolitana Weismann, 1883, Millardiana longitentaculata Wedler and Larson, 1986, is clearly a distinct species. Characteristics of the latter distinguishing it from the former include the intense red pigmentation of the hydranths and the extremely long tentacles and hypostome. According to Wedler and Larson (1986), gonophores are sporosacs borne on polyps having only four to five tentacles. From their description and illustration, these remarkable polyps somewhat resemble the gonozooids of the family Hydractiniidae L. Agassiz, 1862, and are atypical of hydroids of the Bougainvilliidae Lütken, 1850.

\section{KNOWN RANGE}

Bermuda: first record.

Elsewhere: western Atlantic (Wedler and Larson, 1986).

\section{Genus Pachycordyle Weismann, 1883}

Pachycordyle Weismann, 1883:87.

?Parvanemus Mayer, 1904:6.

Pachycordile Lo Bianco, 1909:544 lincorrect subsequent spellingl.

Clavopsella Stechow, 1919:21.

\section{DIAGNOSIS}

Bougainvilliid hydroids with the characters of the subfamily.

Gonophores fixed sporosacs or free but degenerate medusae. Medusa ephemeral, pyriform, without mouth, radial canals, marginal tentacles, oral tentacles, or ocelli.

\section{TYPE SPECIES}

Pachycordyle napolitana Weismann, 1883, by monotypy. 


\section{REMARKS}

Pachycordyle napolitana Weismann, 1883, and $P$. weismanni Hargitt, 1904a, type species of the nominal genera Pachycordyle Weismann, 1883, and Clavopsella Stechow, 1919, respectively, are regarded here as conspecific following Picard (1958) and Morri (1981). The name Clavopsella can therefore be regarded as a junior subjective synonym of the name Pachycordyle, resurrected here.

Picard (1958) and Morri (1981) included P. napolitana in the genus Cordylophora Allman, 1844. Pachycordyle differs from Cordylophora in having tentacles arranged in two or more close whorls rather than scattered over much of the hydranth.

Stechow (1919) proposed the generic names Clavopsella and Balella for species of Filifera having more than one whorl of tentacles on the hydranth. Unlike hydroids of Balella, which have two widely separated whorls of tentacles, hydroids of Clavopsella (= Pachycordyle) have from two to four close whorls of tentacles. This characteristic is shared with Silhouetta Millard and Bouillon, 1973, a genus with well-developed medusa buds instead of fixed sporosacs or free but degenerate medusae.

The nominal genus Clavopsella was initially referred to the family Bougainvilliidae Lütken, 1850, by Stechow (1919), but was later transferred to the Clavidae McCrady, 1859a, by Stechow (1923a). Thiel (1962) placed Clavopsella with Balella in a new family, the Clavopsellidae, a family he considered intermediate between the Clavidae and the Bougainvilliidae. As noted above, Balella is regarded as closer to the Clavidae than the Bougainvilliidae and is returned here to the family Balellidae. Clavopsella (i.e., Pachycordyle) is classified among the Bougainvilliidae in this report, following Millard (1975) and Bouillon (1985).

The definition of Pachycordyle adopted above differs from that used by Thiel (1962) and Millard (1975) for Clavopsella. They included Clavopsella quadranularia Thiel, 1962, and Rhizorhagitum navis Millard, 1959b, nominal species likely referable to Aselomaris Berrill, 1948, in Clavopsella. Aselomaris, in my opinion, belongs in the subfamily Bougainvilliinae rather than in the Pachycordylinae.

Parvanemus Mayer, 1904, established for a species $(P$. degeneratıs Mayer, 1904) whose medusa lacked tentacles, radial canals, marginal sense organs, and presumably a ring canal, was included by Mayer (1910) in the synonymy of Pachycordyle.

Pachycordyle napolitana Weismann, 1883

Figs. 11, 12

Pachycordyle napolitana Weismann, 1883:87; pl. 6, fig. 6 .
Pachycordyle weismanni Hargitt, 1904a:553; pl. 21, figs. $1-8$.

Cordylophora annulata Motz-Kossowska, 1905:66; fig. 5.

Pachycordyle neapolitana-Motz-Kossowska, 1905:70 [incorrect subsequent spelling].

Perigonimus neapolitamus-Motz-Kossowska, 1905:75: fig. 8 [incorrect subsequent spelling] [not Perigonimus napolitanus Hargitt, 1904a].

Pachycordile weismanni-Lo Bianco, 1909:544 [incorrect subsequent spelling].

Tubiclava amnulata-Stechow, 1912:343; pl. 13, fig. 8. Clavopsella weismanni-Stechow, 1919:22.

Clavopsella annulata-Stechow, 1921a:250.

Rhizorhagium (Pachycordyle) napolitanum-Stechow, 1923a:56

Cordylophora neapolitana - Picard, 1958:189 [incorrect subsequent spelling].

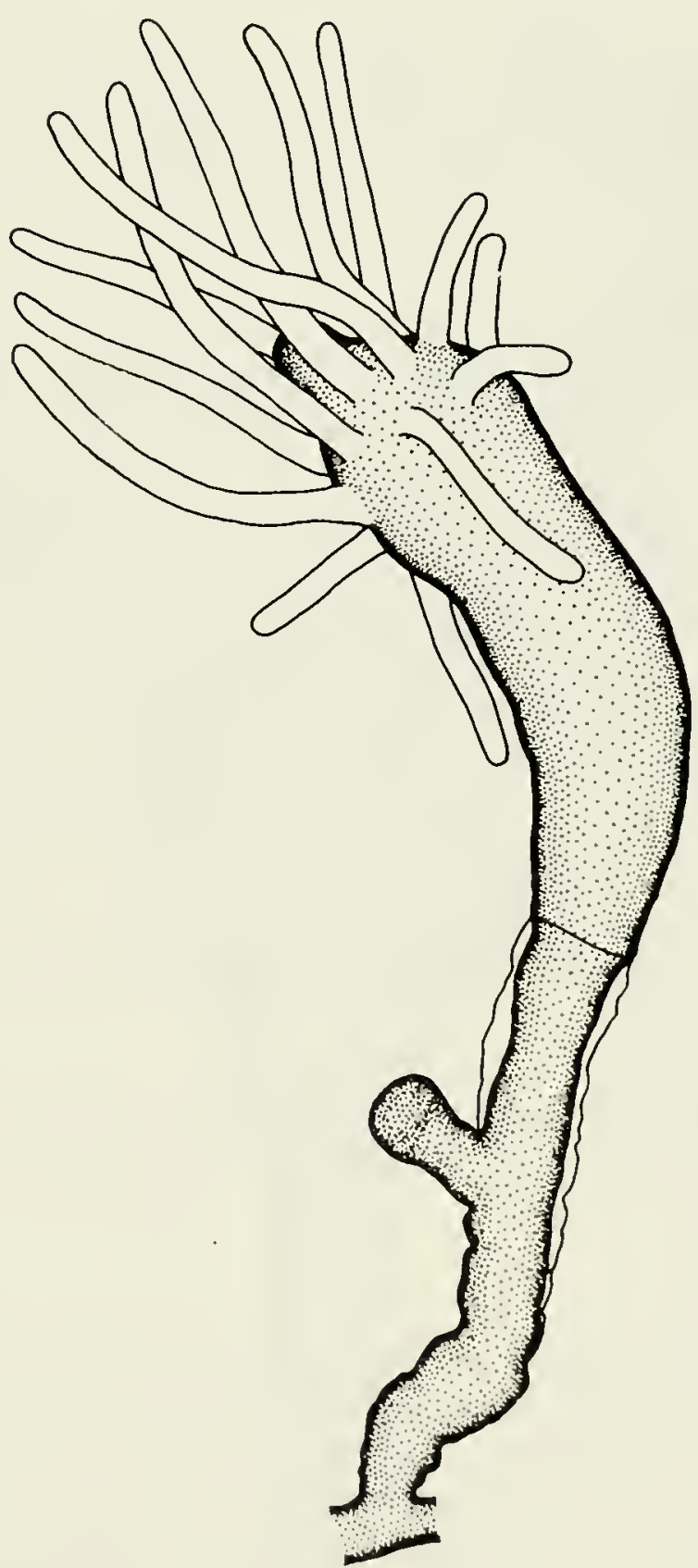

FiG. 11. Pachycordyle napolitana, hydranth, RoMIz B154 Scale equals $0.5 \mathrm{~mm}$. 

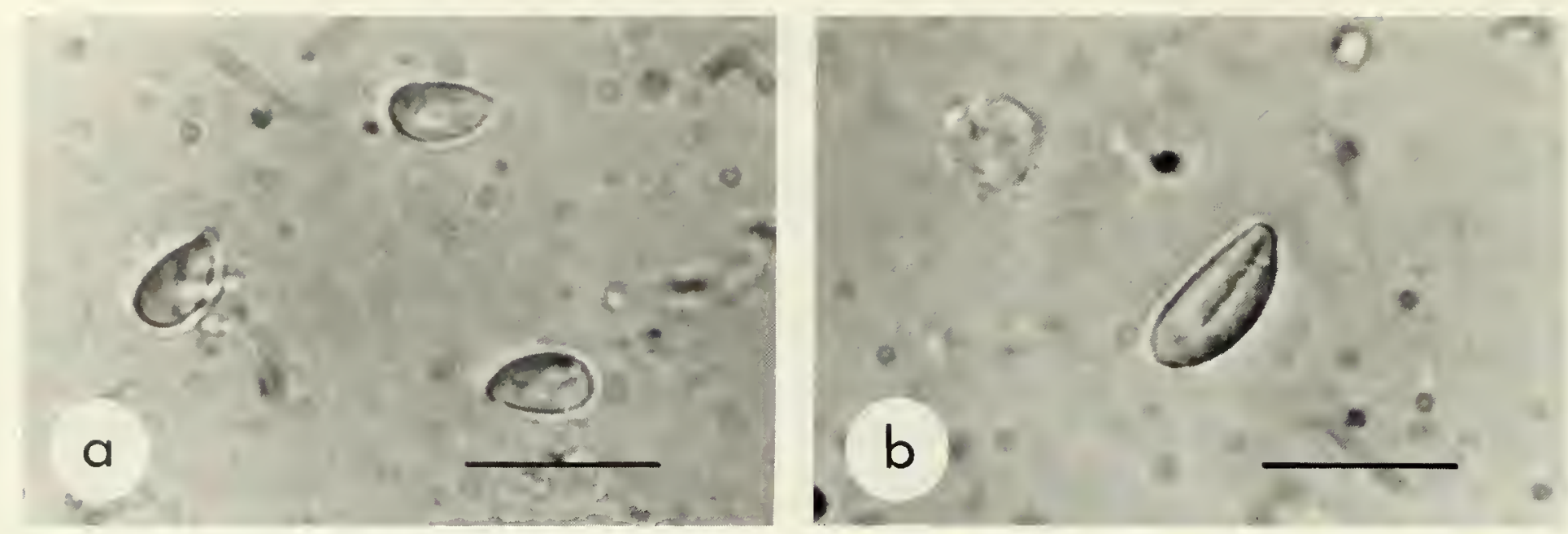

FiG. 12. Pachycordyle napolitana, nematocysts of hydranth, Romiz BI54. Scales equal $10 \mu \mathrm{m}$. $a$, Desmonemes. $b$, Heterotrichous microbasic eurytcle.

TYPE LOCALITY

Naples, ltaly.

\section{MATERIAL, EXAMINED}

Green Bay, Harrington Sound, on gastropod from Thalassia bed, - 2 m, 8 March 1982, one colony, $2 \mathrm{~mm}$ high, with an incipient gonophore, ROMIZ B154.

\section{DESCRIPTION}

Colony stolonal, with reticular hydrorhiza growing over a gastropod shell. Pedicels of varied length but usually less than $1 \mathrm{~mm}$ long, slender basally, widening distally, bearing a terminal hydranth. Perisarc moderately thin, wrinkled throughout, terminating at base of hydranth; pseudohydrotheca absent. Hydranths club-shaped to spindle-shaped, reaching $1.0 \mathrm{~mm}$ long, $0.45 \mathrm{~mm}$ wide at widest point, distal end of fully developed hydranth with about 16 to 20 filiform tentacles in three or four close whorls, tentacles of one whorl alternating with those of adjacent whorls, proximal tentacles often smaller than distal ones. Hypostome dome-shaped.

Incipient gonophore(?) arising singly from hydranth pedicel on short, wrinkled stalk, completely invested with perisarc. Sex indeterminable.

Nematocysts-

Hydroids: desmonemes 5.6-6.0 $\mu \mathrm{m} \times 3.0-3.6 \mu \mathrm{m}$; heterotrichous microbasic euryteles $9.1-9.6 \mu \mathrm{m} \times 3.8-$ $4.5 \mu \mathrm{m}$.

\section{REMARKS}

Thiel (1962) distinguished Clavopsella weismanni (Hargitt, 1904a) and $C$. annulata (Motz-Kossowska, 1905) on the basis of hydroid colony shape and presence or absence of radial canals in the medusa. According to his key, the hydrocaulus of $C$. weismanni is slightly branched and its medusa has radial canals, whereas in $C$. ammulata the hydrocaulus is unbranched and radial canals are lacking.
Branching of the hydrocaulus is not regarded here as particularly reliable in separation of the two. Radial canals were not reported in the degenerate and ephemeral medusae of either nominal species in earlier descriptions (Hargitt, 1904a; Motz-Kossowska, 1905; Stechow, 1919, 1923a). A vestigial ring canal, observed in the medusa of Pachycordyle weismanni by Hargitt (1904a), was not reported in $P$. annulata by Motz-Kossowska (1905). Hydroids and degenerate medusae of both nominal species appear similar based on existing descriptions, and the two have been regarded conspecific by Picard (1958), Morri (1981), and others. I have followed Picard and Morri in regarding both of these as conspecific with $P$. napolitana Weismann, 1883. Picard (1958) included Mediterranean records of Tubiclava fruticosa Allman, 1871, under this species as well.

Material from Bermuda discussed here closely resembles specimens (ROMIZ B695) and published descriptions of Pachycordyle napolitana from the Mediterranean, and has been identified as such. However, specimens with well-developed gonophores are needed for more definitive identification.

\section{KNOWN RANGE}

Bermuda: first record.

Elsewhere: western Atlantic (Wedler and Larson, 1986); Mediterranean Sea (Morri, 1981).

\section{Genus Silhouetta Millard and Bouillon, 1973}

Silhouetta Millard and Bouillon, 1973:25

\section{DIAGNOSIS}

Hydroid colonies stolonal or erect, with firm perisarc terminating at hydranth base. Hydranths large, amphorashaped; tentacles filiform, in two or more close whorls, those of one whorl alternating with those of adjacent whorls. 
Gonophores free medusae, arising in clusters from stem or branches. Medusae at liberation with four simple or dichotomously branched oral tentacles arising above mouth. Tentacle bulbs four; marginal tentacles four, solitary. Ocelli present.

\section{TYPE SPECIES}

Silhouetta uvacarpa Millard and Bouillon, 1973, by monotypy.

\section{REMARKS}

The genus Silhouetta was founded by Millard and Bouillon (1973) to accommodate the hydroid S. uvacarpa Millard and Bouillon, 1973, from the Seychelles. Although they recognized the similarity of their hydroid to specimens previously referred to Clavopsella Stechow, 1919, a new genus was established because well-developed medusa buds were present instead of fixed sporosacs or degenerate medusae.

Sillouetta appears to be distinct from Clavopsella, and its senior synonym Pachycordyle Weismann, 1883, even if gonophore type is not regarded as a valid generic character. Although hydranth shape is typically variable in bougainvilliid hydroids, all the hydranths of $S$. uvacarpa from Bermuda, like those illustrated by Millard and Bouillon (1973) from the Seychelles, had a characteristic amphora shape.

\section{Silhouetta uvacarpa Millard and Bouillon, 1973}

Figs. 13, 14

Silhouetta uvacarpa Millard and Bouillon, 1973:25; figs. 3A-D; pls. 2, 3.

Silhouetta puertoricensis Wedler and Larson, 1986:91; figs. 9Aa,b.

\section{TYPE LOCALITY}

Silhouette, Seychelles.

\section{MATERIAL EXAMINED}

Sailor's Choice Cave, near Walsingham Pond, Hamilton Parish, $-1.0 \mathrm{~m}, 6$ July 1982,16 colonies, $1.0-2.3 \mathrm{~cm}$ high, without gonophores, coll. T. Iliffe, ROMIz BI38.

\section{DESCRIPTION}

Colonies initially stolonal, later erect, reaching $2.3 \mathrm{~cm}$ high, arising from a creeping hydrorhiza. Hydrocaulus monosiphonic in young colonies, polysiphonic in older ones, irregularly branched; primary branches unbranched or irregularly branched; hydrocaulus and branches curved and twisted, imparting a straggly appearance to colony. Perisarc irregularly wrinkled and creased but with annulations absent, moderately thick and golden in colour basally, becoming progressively thinner and more colourless distally, terminating at hydranth base. Hydranth amphorashaped, with conical hypostome, wrinkled basally, reaching $1.5 \mathrm{~mm}$ long from base to tip of hypostome, up to $0.9 \mathrm{~mm}$ wide at widest point, bearing filiform tentacles distally. Young hydranths with about 8 tentacles in two whorls; older hydranths with up to 24 tentacles in four rather close whorls, tentacles of one whorl alternating with those of adjacent whorls, proximal tentacles often shorter and more slender than distal ones.

Gonophores lacking.

Nematocysts-

Hydroids: desmonemes $6.7-7.6 \mu \mathrm{m} \times 3.7-3.9 \mu \mathrm{m}$; heterotrichous microbasic euryteles $9.6-12.7 \mu \mathrm{m} \times 4.4-$ $5.6 \mu \mathrm{m}$.

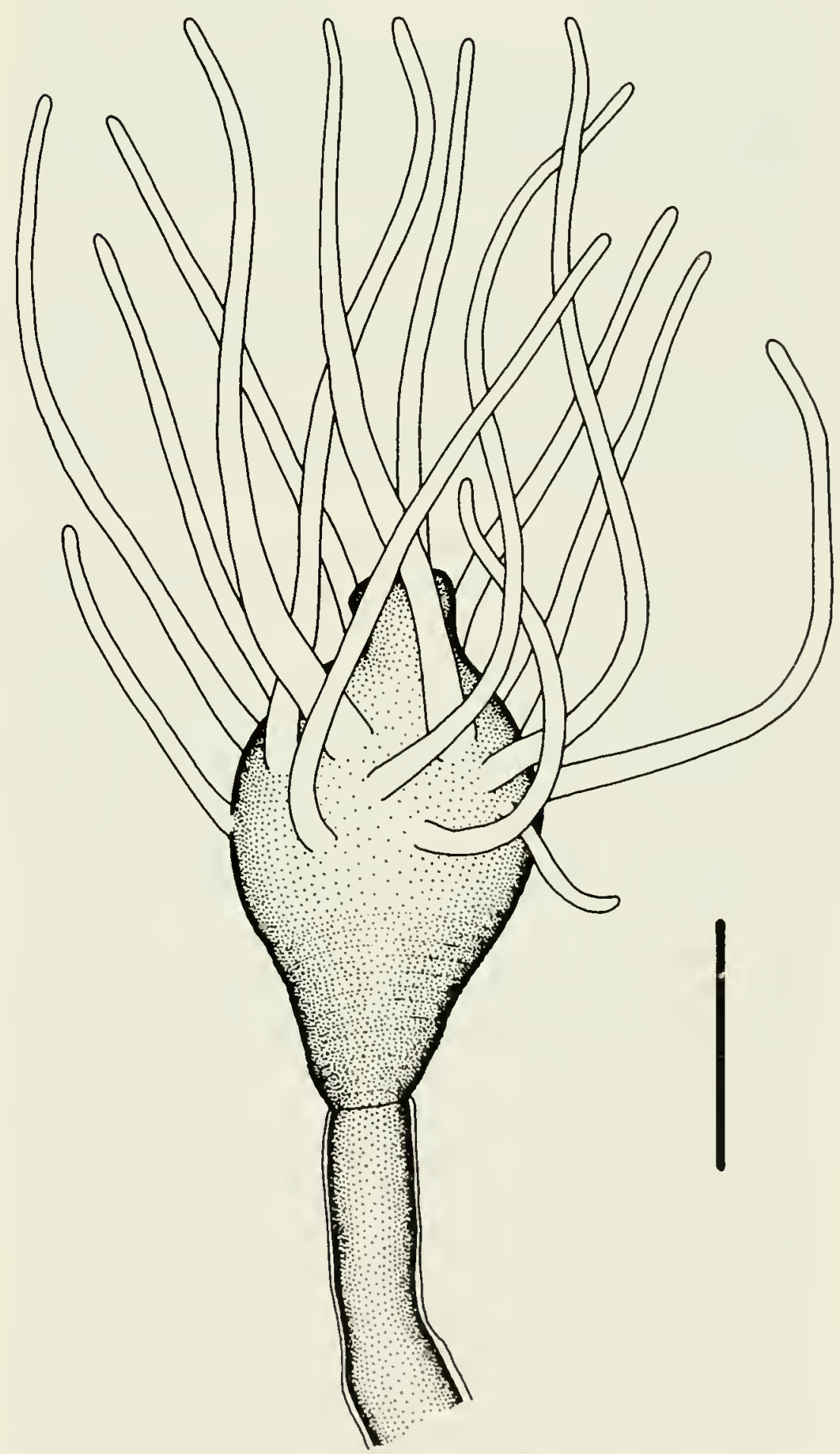

Fig. 13. Silhowetra wracarpa, hydranth, Rome B138. Scale equals $0.5 \mathrm{~mm}$. 


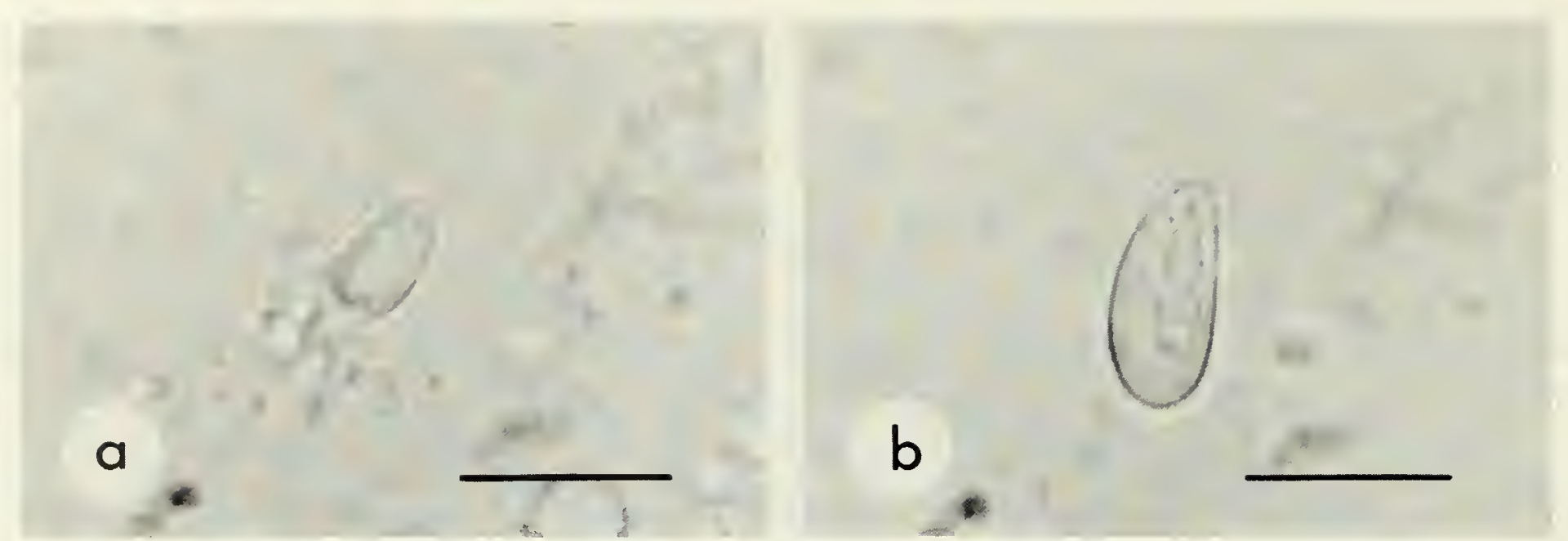

FiG. 14. Silhouetta uvacarpa, nematocysts of hydranth, Romiz B138. Scales equal $10 \mu \mathrm{m} . a$, Desmoneme. $b$, Heterotrichous microbasic eurytele.

\section{REMARKS}

These hydroids lacked gonophores, but resembled the original description of Silhouetta uvacarpa Millard and Bouillon, 1973, in all other major respects, including nematocyst complement and size.

Fully developed medusa buds and newly liberated medusae of Silhouetta uvacarpa were described by Millard and Bouillon (1973, 1975). Large medusa buds bore four marginal tentacle bulbs, each with a single tentacle and black ocellus, and simple oral tentacles inserted above the mouth. Newly liberated medusae were $0.9 \mathrm{~mm}$ high and
$1.0 \mathrm{~mm}$ wide, with four dichotomously branched oral tentacles.

Silhouetta puertoricensis, described by Wedler and Larson (1986) from Puerto Rico, is regarded here as conspecific with $S$. uvacarpa. Wedler and Larson established a new species for their material because oral tentacles could not be seen in the medusa buds.

\section{KNOWN RANGE}

Bermuda: first record.

Elsewhere: western Atlantic (Wedler and Larson, 1986); Indian Ocean (Millard and Bouillon, 1973).

\section{Subfamily Rhizorhagiinae, subf. nov.}

\section{DIAGNOSIS}

Bougainvilliid hydroids with perisarc extending as a pseudohydrotheca around hydranth. Hydranths vasiform; hypostome nipple-shaped; tentacles in two or more close whorls.

Gonophores, where known, fixed sporosacs.

\section{REMARKS}

The hypostome of the Rhizorhagiinae, subf. nov., is elongate and nipple-shaped instead of dome-shaped as in the Bougainvilliinae Lütken, 1850, Pachycordylinae Cockerell, 1911, and Bimeriinae Allman, 1872. Moreover, the hydranths are decidedly vasiform, resembling those of the Eudendriidae L. Agassiz, 1862, as much or more than those of other subfamilies of the Bougainvilliidae. This is not to imply that the subfamily is especially close to the Eudendriidae. Unlike in eudendriids, in the Rhizorhagiinae the hypostome is not flared or knob-shaped and gonophores do not arise from the hydranths. Like the Pachycordylinae, this subfamily has hydroids with tentacles arranged in two or more close whorls on the hydranth. A pseudohydrotheca is present, but it is not as extensively developed as in the
Bimeriinae, in which perisarc extends as a sheath over the bases of the tentacles and the hypostome.

Included in the subfamily are the genera Rhizorhagium M. Sars, 1874, and Parawrightia Warren, 1907. Although only Parawrightia is represented in Bermuda, Rhizorhagitum was chosen as the type genus of the taxon because it is better known [Recommendation 64A].

\section{Genus Parawrightia Warren, 1907}

Parawrightia Warren, 1907:187.

\section{DIAGNOSIS}

Bougainvilliidae with branched or unbranched hydrocaulus; perisarc extending as a distinct pseudohydrotheca over base of hydranth nearly to tentacles. Hydranth vasiform; manubrium nipple-shaped; tentacles in several close, alternating whorls.

Gonophores fixed sporosacs, enveloped in perisarc, bome on hydrocaulus and branches. 
TYPE SPECIES

Parawrightia robusta Warren, 1907, by monotypy.

\section{REMARKS}

Parawrightia Warren, 1907, is recognized as a valid name here, although it has not been widely adopted even for its type species. It bears some resemblance to Wrightia Allman, 1872, but the name of the latter is an invalid junior homonym of Wrightia L. Agassiz, 1862, a name given to a genus of thecate hydrozoans. Berrill (1948) instituted the new genus Aselomaris to accommodate Atractylis arenosa Alder, 1862, type species of Wrightia Allman, 1872 , by monotypy, and for a new species, A. michaeli. Neither of the two species originally included was designated by Berrill (1948) as type of his new nominal genus. Atractylis arenosa is herein designated as type species of Aselomaris. Wrightia Allman, 1872 (not Wrightia L. Agassiz, 1862) thus becomes an objective synonym of Aselomaris, having the same type species. Aselomaris differs from Parawrightia in having fusiform to clavate hydranths with a dome-shaped hypostome, like hydranths of Bougainvillia Lesson, 1830, instead of vasiform hydranths with a nipple-shaped hypostome. Hydranths of many bougainvilliid hydroids are admittedly variable in shape, depending upon degree of expansion, but those of Parawrightia are quite consistent in form and clearly distinct from those of Aselomaris.

Stechow (1923a), Millard (1975), and Bouillon (1985) included Parawrightia as a synonym of Rhizorhagium M. Sars, 1874 . It is improbable that $R$. roseum M. Sars, 1874 , and P. robusta Warren, 1907, type species of Rhizorhagitum and Parawrightia respectively, are congeneric. Rhizorhagium differs in having simple unbranched stems, tentacles arranged in a single whorl on the hydranth, and gonophores on the hydrorhiza or rhizocaulome rather than on the hydrocaulus (Rees, 1938). Therefore, both genera are recognized as valid here. The name Rhizorhagium has on occasion (e.g., Rees, 1938; Millard, 1975) been attributed to M. Sars (1877), but it was actually made available earlier by M. Sars in G. O. Sars (1874). Millard (1975) and Bouillon (1985) mistakenly included Wrightia Allman, 1872, as a synonym of Rhizorhagium; instead, it is an objective synonym of Aselomaris, as noted above.

Stechow (1923a) regarded Parawrightia and Pachycordyle Weismann, 1883, as synonyms. The genus Pachycordyle is poorly understood at present, but it seems highly unlikely that it is congeneric with Parawrightia. Pachycordyle weismanni Hargitt, 1904a, type species of the nominal genus Clavopsella Stechow, 1919, liberates free but degenerate medusac (Hargitt, 1904a; Brinckmann-Voss, pers. comm., 1986); its hydranths are claviform to fusiform, and its hypostome is subconical. Based on such differences, I conclude that Parawrightia and Clavopsella are distinct. In this report, Clavopsella is regarded as identical with Pachycordyle.

Parawrightia shows some remarkable similarities to Cordylophora Allman, 1844, a genus usually included in the family Clavidae McCrady, 1859a. In both genera, colonies are typically branched, gonophores are fixed sporosacs occurring on hydrocaulus and branches, and hydranths are similar in shape. Nevertheless, tentacles are somewhat less scattered and a pseudohydrotheca is present in Parawrightia, and this genus is considered distinct from Cordylophora here.

Finally, Parawrightia differs from Sithouetta Millard and Bouillon, 1973. Unlike in Silhouetta, gonophores of Parawrightia are solitary, fixed sporosacs instead of grapelike clusters of medusa buds that become free medusae. In addition, hydranths are vasiform in Parawrightia instead of spindle-shaped.

Parawrightia was founded by Warren (1907) for a single new nominal species, Parawrightia robusta, and is still monotypic. It seems debatable whether the genus should be referred to the Bougainvilliidae Lütken, 1850, although it is discussed under that family here.

\section{Parawrightia robusta Warren, 1907}

Figs. 15, 16

Parawrightia robusta Warren, 1907:187; figs. 1, 2B, 3 , 4: pls. 33, 34.

Rhizorhagium robustum-Millard, 1966:452.

Garveia robusta-Wedler and Larson, 1986:90; figs. 8Ba-d; pl. 1 , fig. 7.

TYPE LOCALITY

Natal, South Africa.

\section{MATERIAL EXAMINED}

Flatts Inlet, on rocks and stems of Eudendrium carneum, $-1 \mathrm{~m}$, 9 July 1983, several colonies, up to $1.5 \mathrm{~cm}$ high, with male gonophores, ROMIz B357. Flatts Inlet, on Thyroscyphus marginatus, $-2 \mathrm{~m}, 4$ July 1983, one colony, up to $1 \mathrm{~cm}$ high, with male gonophores, Romiz B358.

\section{DESCRIPTION}

Colonies stolonal or erect, reaching $1.5 \mathrm{~cm}$ high, arising from a creeping hydrorhiza. Hydrocaulus monosiphonic, slender, unbranched or irregularly branched; hydrocaulus and branches usually somewhat crooked; colonies tangled and straggly. Perisare fairly thick, smooth or wrinkled, extending as a thin pseudohydrothecal over hydranth base nearly to tentacles. Hydranths vasiform, about $1.1 \mathrm{~mm}$ long from base to tip of hypostone, $0.5 \mathrm{~mm}$ wide at widest point; hypostome conical, elongate. Tentacles filiform, tipering gradually from base to tip, up to about 26 in num- 
ber. arranged in two or three close whorls, those of one whorl more or less alternating with those of adjacent whorls, proximal tentacles smaller than distal ones.

Gonophores fixed sporosacs, completely enveloped in thin perisarc, arising singly on short, smooth pedicels from hydrocaulus. or from hydrocaulus and branches.

Nematocysts-

Hydroids: desmonemes 4.8-5.3 $\mu \mathrm{m} \times 2.7-2.9 \mu \mathrm{m}$; heterotrichous microbasic euryteles 7.3-7.5 $\mu \mathrm{m} \times 3.7$ $3.8 \mu \mathrm{m}$.

\section{REMARKS}

Warren (1907) described this hydroid as a new genus and species, naming it Parawrightia robusta. Millard (1966. 1975), without comment, placed it in the genus $R h i$ zorhagium M. Sars, 1877. According to Rees (1938), Rhizorhagium has simple, unbranched stems and tentacles arranged in a single whorl. Warren's hydroid, with typically branched hydrocauli and tentacles in several whorls, is recombined here with Parawrightia.

In Bermuda, the hydroid was found on ceilings of cavities in the rocky shoreline near the bridge at Flatts Inlet.

\section{KNOWN RANGE}

Bermuda: first record.

Elsewhere: western Atlantic (Florez Gonzalez, 1983); Indian Ocean (Millard. 1975).
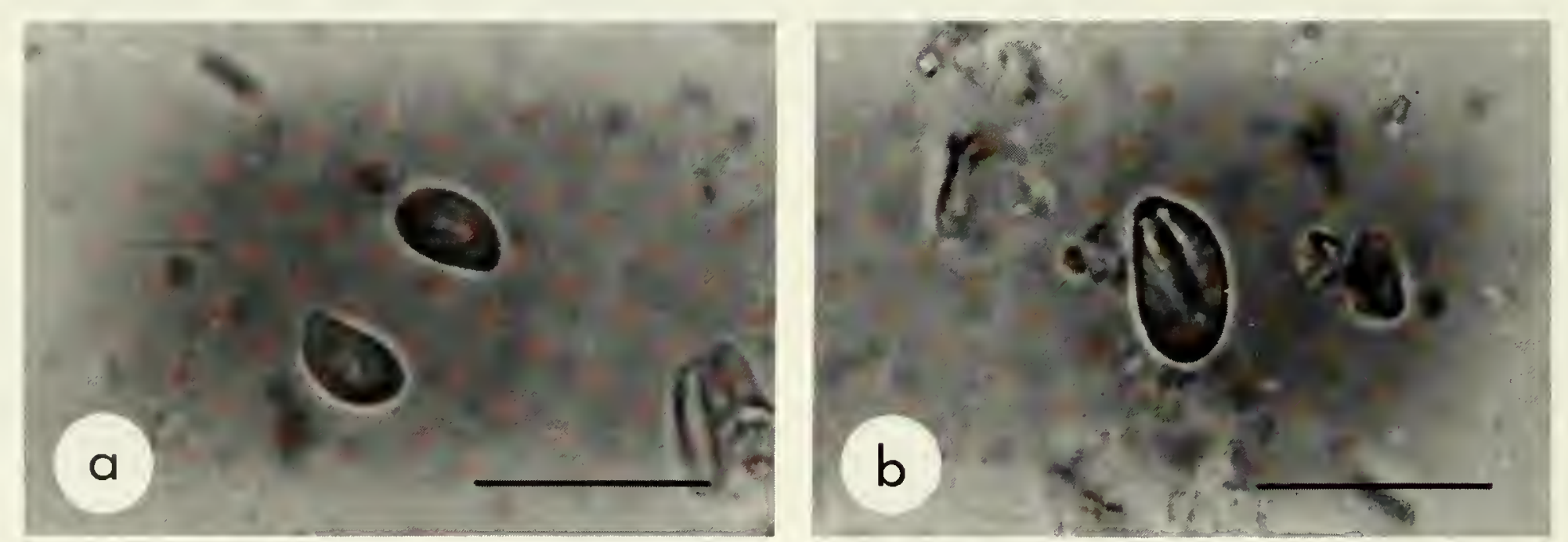

FIG. 16. Parawrightia robusta, nematocysts of hydranth, Romiz B357. Scales equal $10 \mu \mathrm{m}$. $a$, Desmonemes. $b$, Heterotrichous microbasic curytele.

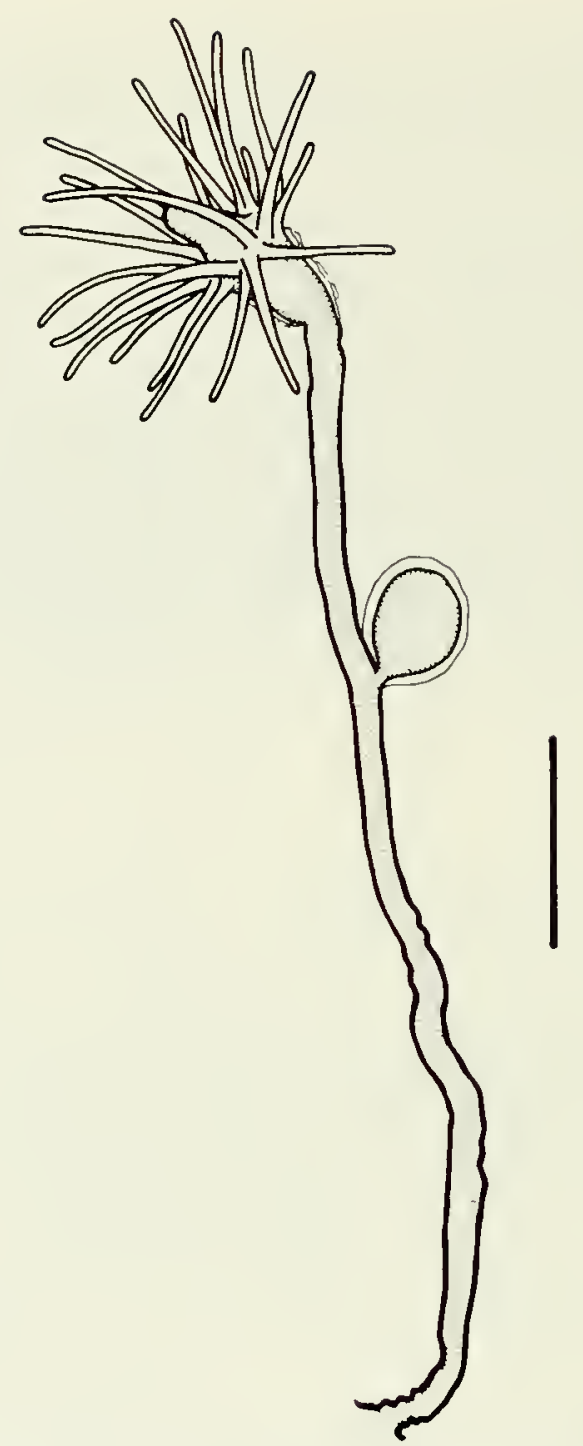

FIG. 15. Parawrightia robusta, hydranth and gonophore, ROMtz B357. Scale equals $1 \mathrm{~mm}$. 


\section{Subfamily Bimeriinae Allman, 1872}

\section{DIAGNOSIS}

Bougainvilliid hydroids with perisarc enveloping hydranth and extending as a sheath over proximal ends of tentacles. Hydranths ovoid to vasiform; hypostome dome-shaped; tentacles in a single whorl or in two close whorls.

Gonophores fixed sporosacs or free medusae; medusae with characteristics of the family. Marginal tentacles solitary or in eight groups. Oral tentacles dichotomously branched.

\section{REMARKS}

Allman (1872) originally included in the family Bimeriidae those genera of bougainvilliids whose hydroids produced fixed sporosacs. This unnatural grouping of taxa was recombined with the Atractylidae Hincks, 1868, by Torrey (1902).

Russell (1953) tentatively referred a hydrozoan to the genus Thamnostoma Haeckel, 1879, under the subfamily Thamnostominae Haeckel, 1879. The hydrozoan that Russell studied has since been referred to Koellikerina Kramp, 1939, by Petersen and Vannucci (1960). This genus is included in a subfamily with Bimeria Wright, 1859, here, under the name Bimeriinae Allman, 1872.

\section{Genus Bimeria Wright, 1859}

Bimeria Wright, 1859:109.

Manicella Allman, 1859a:51.

\section{DIAGNOSIS}

Hydroids with the characters of the subfamily.

Gonophores fixed sporosacs.

\section{TYPE SPECIES}

Bimeria vestita Wright, 1859, by monotypy.

\section{REMARKS}

The generic names Bimeria Wright, 1859, and Manicella Allman, 1859a, are simultaneous synonyms, having both been published in July 1859 for the same species. Allman (1864a) seemed uncertain that Manicella and Bimeria were congeneric. Later, he conceded (Allman, 1872) that the type species of the two genera, Bimeria vestita Wright, 1859, and Manicella fusca Allman, 1859a, were "almost certainly the same species" and recognized Bimeria as the valid name. Hincks (1868), acting as first reviser /Art. 24], had earlier chosen Bimeria as the name having precedence.

Life-cycle studies by Brückner (1914) and Rees (1938) showed that hydroids of the medusae of Perigonimus cidaritis Weismann, 1883, and Thamnostoma russelli Rees,
1938, are similar to those of Bimeria vestita, type species of Bimeria, although $B$. vestita produces fixed gonophores instead of free medusae. Petersen and Vannucci (1960) referred $P$. cidaritis and $T$. russelli, as well as material identified as Thamnostoma sp. by Browne (1905), to Koellikerina fasciculata (Péron and Lesueur, 1807). Petersen and Vannucci noted that hydroids of Thamnostoma Haeckel, 1879, are unknown.

Rees (1938), Vervoort (1964), and others have pointed to the relationship between hydroids of Garveia Wright. 1859, and Bimeria. The two have been regarded as congeneric by some authors (e.g., Torrey, 1902: Browne, 1907; Stechow, 1919, 1923a; Bouillon, 1985). Bimeria differs from Garveia in having a perisarcal sheath over the base of the tentacles, and 1 agree with authors such as Rees (1938), Vervoort (1964), and Millard (1975) that the two should be regarded as distinct. In fact, as reported by Mammen (1963), Garveia appears to resemble Bougainvillia Lesson, 1830, more than it does Bimeria.

Identical accounts of the genus Bimeria and its type species, $B$. vestita, were published in two different journals by Wright $(1859,1863 \mathrm{a})$. Also duplicated in these two papers were accounts of the nominal species Coryne implexa (Alder, 1856b), Coryne margarica Wright. 1859. and Garveia mutans Wright, 1859.

\section{Bimeria vestita Wright, 1859 \\ Figs. 17, 18}

Bimeria vestita Wright, 1859:109; pl. 8, fig. 4.

Manicella fusca Allman, 1859a:51.

Bimeria humilis Allman, 1877:8; pl. 5, figs. 3,4.

Perigonimus vestitus-Motz-Kossowska, 1905:74.

not Bimeria vestita-Annandale, 1907:141; fig. 3 I= Garveia franciscana (Torrey, 1902)].

Bimeria vestita f. nana Leloup, 1932:142; fig. 14.

Leuckartiara vestita f. nana-Vervoort, 1946a:294.

Leuckartiara vestita-Vervoort, 1946a:295.

Perigonimus vestita-Mammen, 1963:42 [incorrect subsequent spellingl.

Garveia humilis-Vervoort, 1968:7

Bimeria (Garveia) umilis-Wedler and Larson, 1986:71 [incorrect subsequent spelling].

\section{TYPE LOCALITY}

Firth of Forth, Scotland.

\section{MATERIAL, FXAMINED}

Flatts lnlet, on undersides of 11 at rocks, $-3 \mathrm{~m}, 2$ August 1982, two colonics, 4 and $5 \mathrm{~mm}$ high. without gonophores, Romiz B 137. Green Bay Cave, Harrington Sound. 


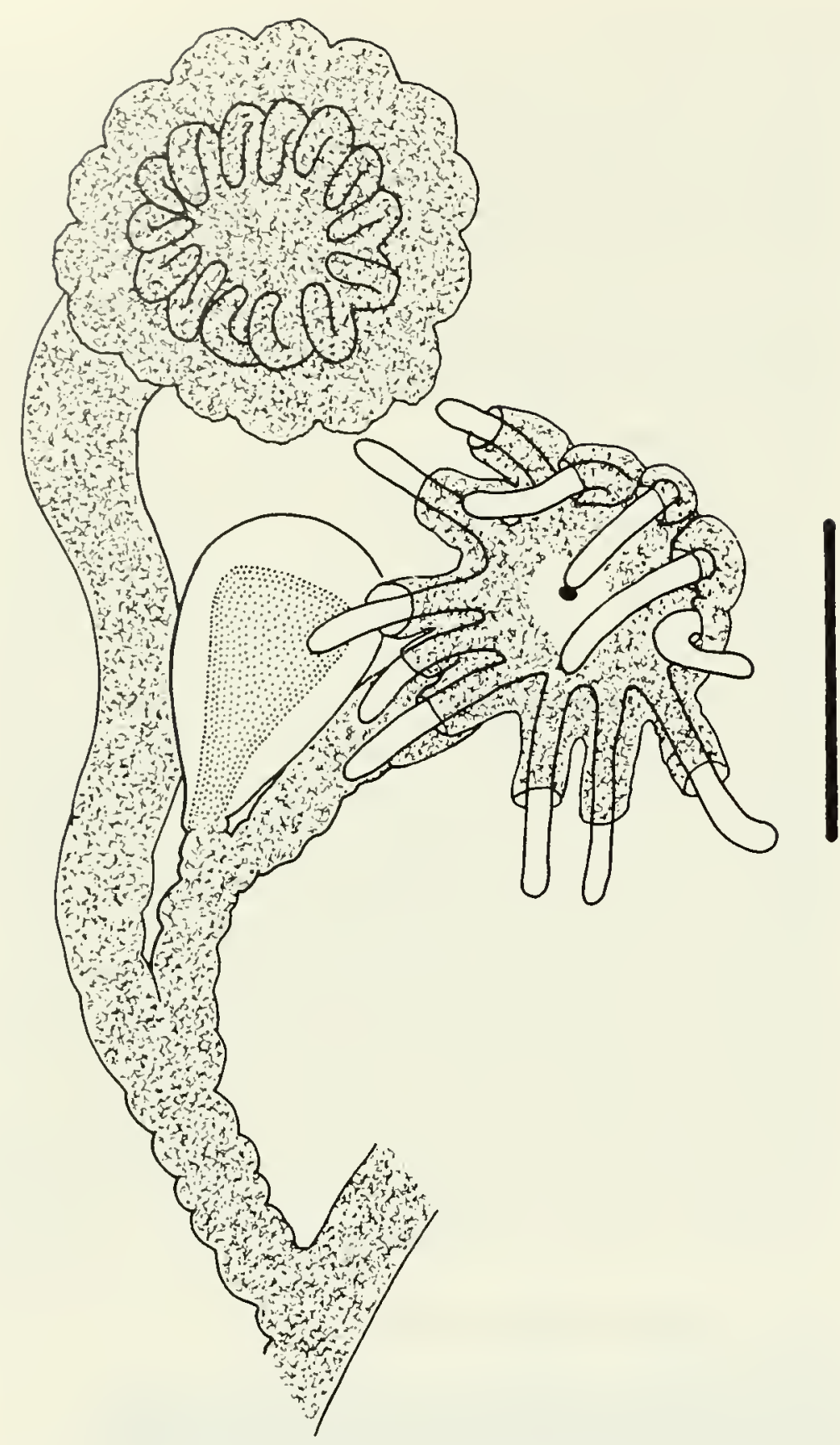

FiG. 17. Bimeria vestita, part of hydrocaulus with two hydranths and gonophore, ROM1z B160. Scale equals $0.25 \mathrm{~mm}$. on Eudendrium carneum, 8 July 1982, one colony, $7 \mathrm{~mm}$ high, with male gonophores, ROMIZ B146. Harrington Sound, at Flatts Bridge, on algae, 21 September 1977. one colony, $1.5 \mathrm{~mm}$ high, with female gonophores, ROMIz B 160 .

\section{DESCRIPTION}

Colonies minute, stolonal or erect, arising from a creeping hydrorhiza. Hydrocaulus monosiphonic, slender basally, gradually expanding distally, either unbranched or sparingly and more or less alternately branched. Perisarc of moderate thickness, annulated or wrinkled at base of hydrocaulus and branches, becoming encrusted with silt and detritus in older colonies, extending as a filmy covering over hydranth and around base of hypostome, forming tubular sheaths around bases of tentacles. Hydranth vasiform, merging almost imperceptibly with pedicel; hypostome conical, tentacles 9 to 16 in number, filiform, in two close whorls.

Nematocysts-

Hydroids: desmonemes $3.8-4.7 \mu \mathrm{m} \times 2.6-2.9 \mu \mathrm{m}$; heterotrichous microbasic euryteles $6.6-7.3 \mu \mathrm{m} \times 3.7-$ $4.5 \mu \mathrm{m}$.

Gonophores fixed sporosacs lacking radial canals and tentacular rudiments, completely enveloped in perisarc, arising singly on short, annulated or wrinkled pedicels from hydrocaulus and branches, less frequently from hydrorhiza. Female gonophores pear-shaped, each bearing a single egg or embryo. Male gonophores pear-shaped to elongate-oval.

\section{REMARKS}

Bimeria vestita Wright, 1859, and Manicella fusca Allman, 1859a, are simultaneous synonyms, as noted above

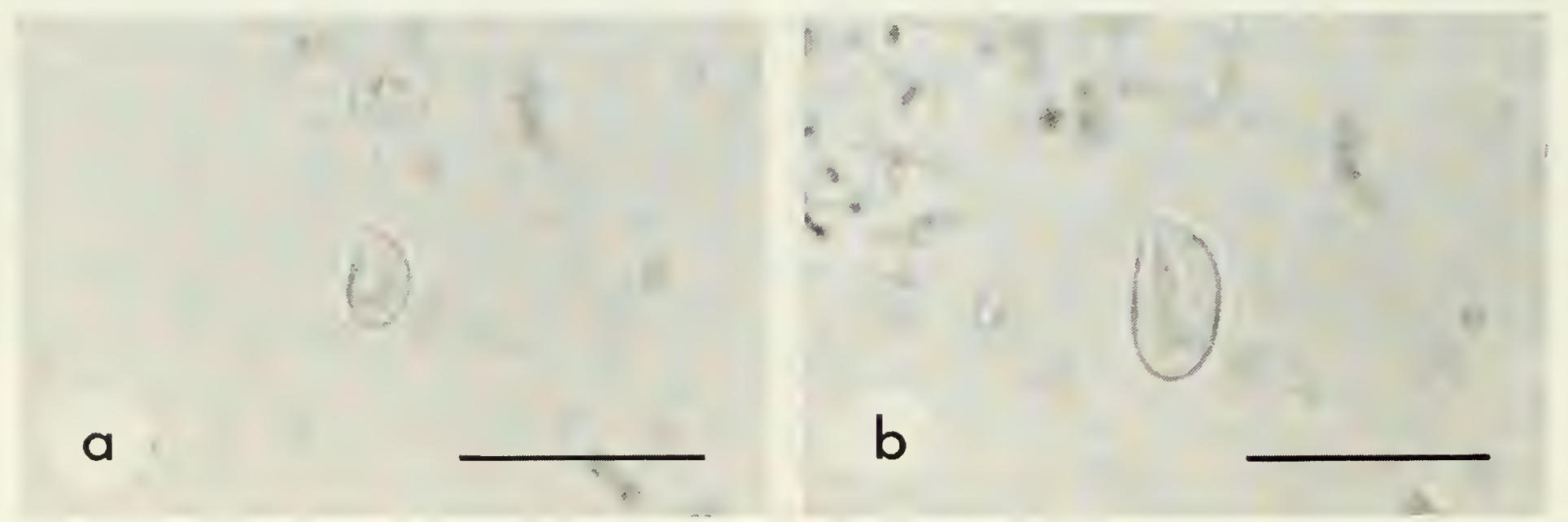

Fig. 18. Bimeria vestita, nematocysts of hydranth. Scales equal $10 \mu \mathrm{m}$. $a$, Desmoneme, Romiz B160. $b$, Heterotrichous microbasic eurytele, ROMiz B137. 
under discussion of the genus Bimeria Wright, 1859. Hincks (1868), the first reviser [Art. 24], chose B. vestita as having precedence over $M$. fusc $a$.

Allman (1877) introduced the name Bimeria humilis for certain hydroids dredged in shallow water off the Tortugas, Florida. He indicated that these specimens differed from $B$. vestita in having "massive hydranths" and a somewhat less branched hydrocaulus. The two nominal species are nevertheless regarded as conspecific here.

Bimeria vestita has been reported from Bermuda before by Congdon (1907), Bennitt (1922), and Calder (1986), as B. humilis. Congdon observed dense growths of this hydroid on species of Eudendrium Ehrenberg, 1834, and Halocordyle Allman, 1872, as well as on sponges.

\section{KNOWN RANGE}

Bermuda: on hydroids and sponges. (Congdon, 1907); listed, with no comment (Bennitt, 1922); in shallow inshore waters, and on wrecks and buoy chains (Calder, 1986).

Elsewhere: western Atlantic (Vervoort, 1968); eastern Atlantic (Picard, 1958); Indian Ocean (Millard, 1975); western Pacific (Leloup, 1937); eastern Pacific (Fraser, 1948).

\section{Subfamily Bougainvilliinae Lütken, 1850}

\section{DIAGNOSIS}

Bougainvilliid hydroids with perisarc terminating at base of hydranth, or extending upwards as a pseudohydrotheca. Hydranth fusiform to clavate; hypostome dome-shaped; tentacles more or less in a single whorl.

Gonophores fixed or motile sporosacs, or free medusae; medusae with characteristics of the family. Marginal tentacles in four perradial groups. Oral tentacles almost always dichotomously branched.

\section{REMARKS}

The subfamily Bougainvilliinae Lütken, 1850, as defined here, encompasses hydroids and medusae of the genera Bougainvillia Lesson, 1830, and Nemopsis L. Agassiz, 1849, as well as hydroids of the genera Dicoryne Allman, 1859b, Garveia Wright, 1859, and Aselomaris Berrill, 1948. Of these, only Bougainvillia is known at present from Bermuda.

\section{Genus Bougainvillia Lesson, 1830}

Bougainvillia Lesson, 1830:118.

Hippocrene Brandt, 1835:29 [invalid junior homonym of Hippocrene Oken, 1817 (Mollusca)].

Perigonimus M. Sars, 1846:8.

Bougainvillea Forbes, 1848:61 [incorrect subsequent spelling].

Perigonymus Forbes, 1848:81 [incorrect subsequent spelling].

Margelis Steenstrup, 1850:35.

Atractylis Wright, 1858a:447.

Bourgainvillea Wright, 1858a:449 [incorrect subsequent spelling].

Perigommus Allman, 1871:24 [incorrect subsequent spelling].

Parigonimus Allman, 1872:325 |incorrect subsequent spellingl.
Bourgainvillia Allman, 1872:433 [incorrect subsequent spelling].

Atractilis Allman, 1872:433 [incorrect subsequent spelling]. Lizusa Haeckel, 1879:80.

Bouganvilleia Brooks, 1883b:468 [incorrect subsequent spelling].

Perigonemus Fewkes, 1891:29 [incorrect subsequent spelling].

Perigonismus Möbius, 1893:89 [incorrect subsequent spelling].

Lizuza Delage and Hérouard, 1901:56 [incorrect subsequent spelling].

Bougainvilla Hargitt, 1902:13 [incorrect subsequent spelling].

Perigominus Hartlaub, 1905:533 [incorrect subsequent spelling].

Hyppocrene Bedot, 1912:259 |incorrect subsequent spelling].

\section{DIAGNOSIS}

Bougainvilliidae with colonies stolonal or erect, with monosiphonic or polysiphonic hydrocaulus. Perisarc soft or firm, terminating at hydranth base or forming a pseudohydrotheca. Hydranth with a single distal whorl of filiform tentacles; hypostome conical.

Gonophores free medusae, arising singly or in clusters from hydrocaulus, branches, or hydrorhiza. Medusae with short manubrium; oral tentacles perradial, usually branched dichotomously. Radial canals four; ring canal present. Marginal tentacles all alike in structure, arising in clusters from four tentacle bulbs. Ocelli usually present. Gonads on manubrium; medusa buds occasionally produced.

\section{TYPE SPECIES}

Bougainvillia macloviana Lesson, 1830, by monotypy.

\section{REMARKS}

The name Bougainvillia has been attributed by many au- 
thors to Lesson (1836), although it was actually founded in an earlier paper by the same author (Lesson, 1830). Likewise, there has been confusion over the name of the type species of the genus because Lesson (1830) first referred to it as Cyanaea bougainvillii. Below this name, but on the same page, Lesson commented that his medusa was not at all a "cyanée" but the type of a new genus named Bougainvillia. He then applied the name $B$. macloviana to the species, making $C$. bougaimvillii and $B$. macloviana simultaneous synonyms. Lesson (1836), acting as first reviser [Art. 24], chose the name B. macloviana for the species. Bongainvillia macloviana is the type species of the genus, not B. ramosa (van Beneden, 1844b) as designated by Allman (1872).

Rees (1938) demonstrated that Perigonimus M. Sars, 1846 , is a junior subjective synonym of Bougainvillia because the hydroid of its type species, P. muscoides $\mathrm{M}$. Sars, 1846, gives rise to medusae referable to Bougainvillia. In a revision of the genus Perigonimus, Rees (1956a) noted that nearly 40 other nominal species had been referred to Perigonitulus at one time or another. These were shown to belong not only to a number of genera, but to at least six families.

Totton (1930) designated Eudendrium ramosum sensu van Beneden, 1844b (not Sertularia ramosa Linnaeus, 1758), referred to Bougainvillia, as type species of Atractylis Wright, 1858a. As noted by Totton (1930) and Rees (1938), Atractylis is, therefore, a subjective synonym of Bougainvillia.

Margelis principis Steenstrup, 1850, which is type species of Margelis Steenstrup, 1850, and the two originally included nominal species of Lizusa Haeckel, 1879, are now all included in Borgainvillia. The names Margelis and Lizusa are, therefore, synonyms of Bougainvillia.

Vannucci and Rees (1961) noted that hydroids of the various species of Bougainvillia are difficult to separate; they differ little from each other, yet are greatly influenced by environmental factors. Vannucci and Rees concluded from their review of the genus that many of the nominal species are of questionable validity. The same opinion was expressed many years earlier by Mayer (1910).

Of the numerous incorrect subsequent spellings [Art. $33 c$ ] of the name Bougainvillia and its synonyms, the most commonly encountered is Bougainvillea, first used by Forbes (1848). The list given here should not be considered complete; 1 was unable to trace and verify several others listed by Neave (1939, 1940a, 1940b).

\section{Bougainvillia muscus (Allman, 1863)}

Figs. 19, 20

Eudendrium ramosum-van Beneden, 1844b:56; pl. 4, figs. 1-13 [hydroid and medusa] [not Eudendrium ramosum (Linnaeus, 1758)]. not Tubularia (Sertularia) ramosa-Dalyell, 1847:64; pl. 11, figs. $1-8[=$ ?Bougainvillia pyramidata (Forbes and Goodsir, 1851)].

Atractylis ramosa-Wright, 1858a:449 [not Eudendrium ramosum (Linnaeus, 1758)].

Bourgainvillea britannica-Wright, 1858a:449 [medusa] [incorrect subsequent spelling] [not Bougainvillia britannica (Forbes, 1841)].

Podocoryne alderi Hodge, 1861:82; pl. 2, figs. 11-15 [medusa, not hydroid].

Margelis ramosa-L. Agassiz, 1862:344 [hydroid and medusa] [not Eudendrium ramosum (Linnaeus, 1758)].

Perigonymus muscus Allman, 1863:12 [incorrect subsequent spelling].

Perigonymus ramosus-Allman, 1863:12 [incorrect subsequent spelling] [not Eudendrium ramosum (Linnaeus, 1758)].

Atractylis (Eudendrium) ramosa-Wright, 1863b:35 [not Eudendrium ramosum (Linnaeus, 1758)].

Corynopsis alderi-Allman, 1864a:354 [medusa, not hydroid].

Bougainvillia ramosa-Allman, 1864a:366 [not Eudendrium ramosum (Linnaeus, 1758)].

Bougainvillia muscus-Allman, 1864a:366.

Bougainvillia fruticosa Allman, 1864a:366 [nomen nudum]. Bougainvillia fruticosa Allman, 1864b:58.

Lizusa octocilia-Haeckel, 1879:80 [part] [not Medusa octocilia Dalyell, $1847=$ ?Bougainvillia pyramidata (Forbes and Goodsir, 1851)].

Bougainvillea ramosa-Pictet, 1893:11 [incorrect subsequent spelling] [not Eudendrium ramosum (Linnaeus, 1758)].

Bougainvillea muscus-Pictet, 1893:11 [incorrect subsequent spelling].

Bougainvillea (Margelis) ramosa-Garstang, 1894:214 [medusa] [not Eudendrium ramosum (Linnaeus, 1758)].

Bougainvillia flavida Hartlaub, 1897:456; pl. 14, fig. 5 [female medusa only].

Bougainvillia autumnalis Hartlaub, 1897:465; pl. 15, figs. 11-13 [medusa].

Lizusa octociliata-Aurivillius, 1898:114 [medusa] [incorrect subsequent spelling].

Lizusa 8-ciliata-Aurivillius, 1898:424 [medusa] [incorrect subsequent spelling].

?Bougainvillia v. benedenii Bonnevie, 1898:468.

?Bougainvillia benedenii Bonnevie, 1898:484; pl. 26, figs. 34,35 [hydroid and medusa].

?Bougainvillia vanbenedeni-Bonnevie, 1899a:43 [incorrect subsequent spelling].

Bougainvillia gibbsi Mayer, 1900a:5; pl. 4, figs. 14,15 [medusa].

Margelis autumnalis-Browne, 1900:708 [medusa].

?Bougainvillia van benedeni-Jäderholm, 1909:46; pl. 3, fig. 5 [incorrect subsequent spelling]. 
?Bougainvillia van benedenii-Broch. 1909:198.

Bongainvillia ramosa var. nana Hartlaub, 1911:189 [medusa].

Bougainvillia triestina Hartlaub, 1911:154; fig. 138 [medusa].

Bougainvillia ramosa var. minima Kramp and Damas, 1925:254 [medusa].

Bongainvillia antumnalis var. magna Babnik, 1948:290; fig. 2 [medusa).

Bougainvillia ramosa f. musca-Millard, 1975:99.

Bougainvillia ramosa f. fruticosa-Millard, 1975:99.

Bougainvillia ramosa f. ramosa-Millard, 1975:99.

Bongainvillia ramosa f. vanbenedenii-Millard, 1975:99.

\section{TYPE LOCALITY}

Torquay (Torbay), Devon, Great Britain.

\section{MATERIAL EXAMINED}

Green Bay Cave, Harrington Sound, on survey line $40 \mathrm{~m}$ from entrance, $-6 \mathrm{~m}, 3$ March 1982, three colonies, 6 $14 \mathrm{~mm}$ high, with medusa buds, coll. T. 1liffe, ROMIZ B152. Flatts Inlet, on Cliona sp., $-0.5 \mathrm{~m}, 27$ February 1982, one colony, $4 \mathrm{~mm}$ high, without medusa buds, ROMIZ B 153. St George's Island, north shore, on oyster on mooring chain, $-2 \mathrm{~m}, 5$ October 1976, one colony, $10 \mathrm{~mm}$ high, without medusa buds, coll. J. Markham, L. Coen, ROMIz B 163. Flatts Inlet, on sponge, $-1.5 \mathrm{~m}, 5$ March 1982, one colony, $7 \mathrm{~mm}$ high, without medusa buds, ROMIZ B 169. Flatts Inlet, on rocks and Eudendrium carneum, $-2 \mathrm{~m}, 4$ July 1983, three colonies, up to $13 \mathrm{~mm}$ high, with medusa buds, newly liberated medusae, and laboratoryreared adult medusae, ROMIz B328.
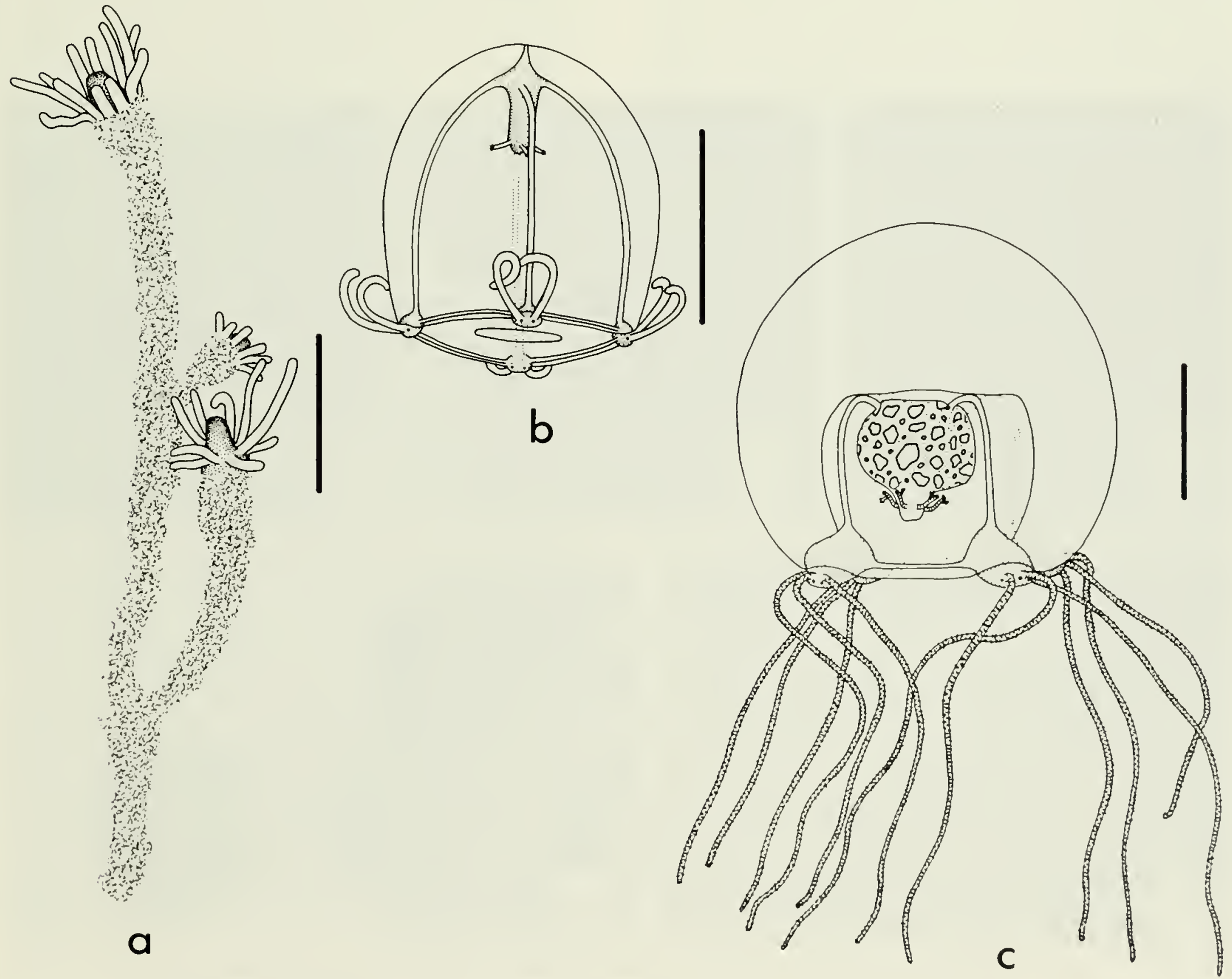

FIG. 19. Bougainvillia muscus. Scales for $a$ and $b$ equal $0.5 \mathrm{~mm}$; scale for $c$ equals $1 \mathrm{~mm}$. $a$, Hydroid colony, ROMIZ B 152. b. Newly liberated medusa, ROMIZ B328. c, Three-day-old adult female medusa, RoMIz B328. 


\section{DESCRIPTION}

Hydroid colony initially stolonal, later erect, reaching $14 \mathrm{~mm}$ high, growing from a creeping hydrorhiza. Hydrocaulus slender, monosiphonic, profusely and more or less alternately branched; primary branches unbranched or somewhat regularly branched; terminal branchlets slender basally, gradually increasing in diameter distally; hydrocaulus and branches curved and twisted, occasionally exhibiting stolonal growth. Perisarc of moderate thickness, smooth or irregularly wrinkled (especially at bases of branches) but not annulated, heavily encrusted with particles of silt and detritus, and extending over base of hydranth as a pseudohydrotheca; pseudohydrotheca cup-shaped in retracted hydranths; perisarc not investing tentacles or hypostome. Hydranth cylindrical when extended, fusiform when contracted, with conical hypostome, bearing tentacles distally. Tentacles slender, filiform, in two close whorls, 10 to 16 in number.
Nematocysts-

Hydroids: desmonemes 3.9-4.6 $\mu \mathrm{m} \times 2.7-3.0 \mu \mathrm{m}$; heterotrichous microbasic euryteles $5.7-6.5 \mu \mathrm{m} \times 2.8-$ $3.4 \mu \mathrm{m}$.

Medusa buds globular, arising singly on stalks of moderate length from pedicels below hydranths, completely invested with perisarc. Newly liberated medusae thimbleshaped, $0.8 \mathrm{~mm}$ high, $0.7 \mathrm{~mm}$ wide; mesoglea of moderate thickness; umbilical canal present; peduncle lacking. Exumbrella with four distinct interradial longitudinal furrows and four somewhat less distinct perradial longitudinal furrows; exumbrellar nematocysts lacking. Manubrium small, tubular, with simple quadrate mouth; oral tentacles four, unbranched, inserting just above mouth, each oral tentacle terminating with small cluster of nematocysts. Radial canals four, joining a narrow ring canal. Marginal bulbs conical, rounded basally, each with two tentacles and two conspicuous black ocelli, each ocellus occurring at base
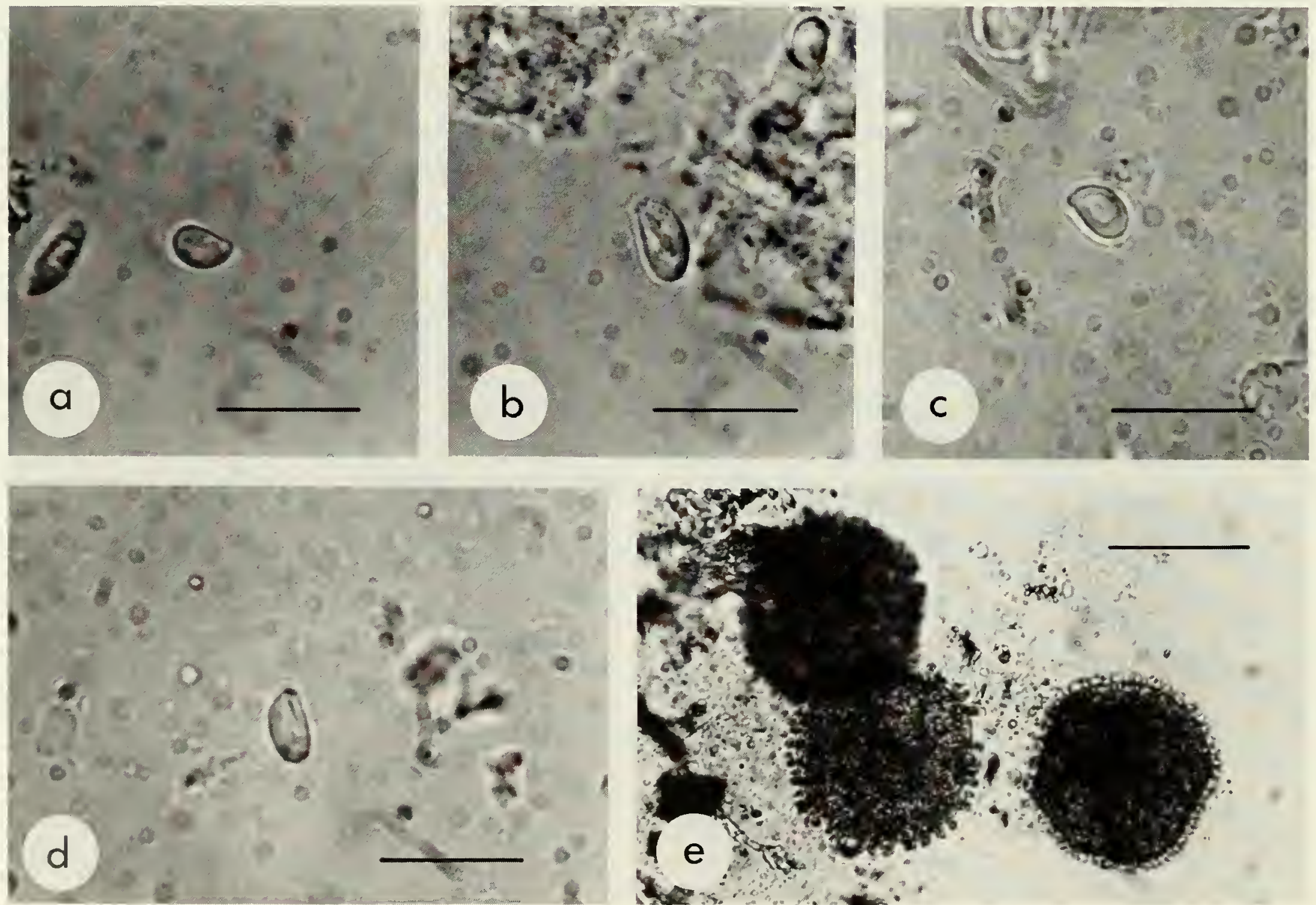

Fig. 20. Bougainvillia muscus, nematocysts, ROMIz B328. Scales for $a-d$ equal $10 \mu \mathrm{m}$; scale for $e$ equals $100 \mu \mathrm{m} . a$, Desmoneme of hydroid. $b$, Heterotrichous microbasic eurytele of hydroid. $c$, Desmoneme of medusa. $d$, Heterotrichous microbasic eurytele of medusa. $e$, Eggs, each with outer envelope of heterotrichous microbasic euryteles. 
of a tentacle. Velum broad. Endoderm of manubrium and tentacle bulbs cream-coloured.

Nematocysts-

Medusae: desmonemes 4.5-5.1 $\mu \mathrm{m} \times 3.0-3.5 \mu \mathrm{m}$; heterotrichous microbasic euryteles $5.3-6.5 \mu \mathrm{m} \times 2.9-$ $3.4 \mu \mathrm{m}$.

One day after liberation, medusae $1.2 \mathrm{~mm}$ high, $1.1 \mathrm{~mm}$ wide; mesoglea thicker, especially at apex. One medusa with an incipient third tentacle on one of four marginal bulbs, incipient tentacle lacking an ocellus basally. Two days after liberation, medusae about $1.5 \mathrm{~mm}$ high and wide, oral tentacles distally bifurcated, and gonads present interradially on manubrium. Each tentacle bulb with a developing third tentacle, varying in length from about half that of original pair to a mere stub. Developing tentacles without ocelli initially, later with ocelli. Three days after liberation, medusae about $2.0 \mathrm{~mm}$ high and wide, oral tentacles divided once, marginal tentacles 12 in number, 3 on each tentacle bulb, and ocelli 10 to 12 in number. Gonads large, mature eggs present, ova with an outer envelope bearing numerous heterotrichous microbasic euryteles $(6.5 \times 3.6 \mu \mathrm{m})$.

\section{REMARKS}

The invalid name Bougainvillia ramosa (van Beneden, 1844b) has been extensively applied to this species in the literature of both hydroids and hydromedusae (e.g., see Hincks, 1868; Allman, 1872; Stechow, 1919; Vervoort, 1946b; Russell, 1953; Kramp, 1961; Vannucci and Rees, 1961; Millard, 1975; and numerous others). Van Beneden (1844b) applied the name Eudendrium ramosum to a bougainvilliid hydrozoan in the mistaken belief that it was conspecific with Tubularia ramosa Linnaeus, 1758, a species now referred to the genus Eudendrium Ehrenberg, 1834. Even though the hydrozoan studied by van Beneden has since been referred to a different genus from the true Eudendrium ramosum (Linnaeus, 1758), the name B. ramosa cannot be retained for the species [Art. 49]. The name $B$. ramosa is replaced here with its oldest available synonym, Bougainvillia muscus (Allman, 1863).

Russell (1953) noted that the synonymy of this species is in doubt because several different hydroid growth forms apparently produce similar medusae. It is still unresolved whether these different hydroid growth forms belong to a single, variable species, or to more than one species. The list of synonyms given here, taken largely and selectively from Bedot (1905, 1910, 1912, 1916, 1918), Russell (1953), Kramp (1961), and Vannucci and Rees (1961), is provisional and not intended to be exhaustive. A thorough taxonomic reassessment of the species is needed.

Records of the hydroid Tubularia (Sertularia) ramosa and the hydromedusa Medusa ocilia (M. octocilia, $M$. sexdecilia, $M$. duodecilia) by Dalyell (1847) have been excluded from the synonymy of this species based on the conclusions of Edwards (1966a), who suggested that they were likely referable to Bougainvillia pramidata (Forbes and Goodsir, 1851). Edwards noted that Dalyell's illustration of the hydroid, found on a sea pen, closely resenbled specimens of $B$. pyramidata from the same substrate examined by Edwards (1964a). Wright (1858a) thought that the medusa of this hydroid was identical with $B$. britannica (Forbes, 1841), and Mayer (1910) among others regarded the two as conspecific. However, these are now considered to be different species (e.g., see Russell, 1953; Kramp, 1961; Vannucci and Rees, 1961; Edwards, 1964b, 1966a).

The nominal species Podocoryne alderi Hodge, 186I, was almost certainly based on a hydroid belonging to $\mathrm{Po}$ docoryna M. Sars, 1846, and a medusa belonging to Bongainvillia muscus (Vannucci and Rees, 1961; Edwards, 1966a, 1972). Allman (1864a) proposed the generic name Corynopsis for the conglomerate P. alderi. Hodge (1861) reported sending "two or three depauperated specimens," along with some sketches, to J. Alder for identification. This material, labelled "Podocoryne alderi Seaham H" (Seaham Harbour, northeast England), and relabelled "Corynopsis alderi Hodge," is represented in the Alder Collection at the Hancock Museum, Newcastle upon Tyne. The hydroid colony consists of a branching and anastomosing stolon network, with occasional short spines and a few hydractiniid hydranths, growing over serpulid polychaete tubes. Since the more widely used name $B$. muscus is predated by Hodge's (1861) nominal species, the name $P$. alderi is restricted here to the hydroid only; the above-cited material from the Hancock Museum is designated as the lectotype [Art. 74]. The name $P$. alderi thus is restricted to Podocoryna, and no longer threatens the name $B$. muscus. Moreover, the generic name Corynopsis Allman, 1864a, becomes a junior subjective synonym of Podocoryna, instead of Podocoryna in part and Bougainvillia in part. Edwards (1972) included $P$. alderi as a questionable synonym of $P$. borealis (Mayer, 1900a), which in turn was viewed as a questionable synonym of $P$. $(u b$ ulariae M. Sars, 1857.

Bongainvillia flavida Hartlaub, 1897, has been regarded as a synonym, or a synonym in part of this species (e.g. see Hartlaub, 1911; Kramp, 1937; Vannucci and Rees, 1961). Edwards (1964a, 1964b) concluded that Hartlaub's (1897) hydroid of $B$. flavida was referable to $B$. britannica. his male medusae to $B$. pyramidata, and his female medusa to "B. ramosa." Bougainvillia antumnalis Hartlaub, 1897. is also a synonym, at least in part, of this species (e.g. see Russell, 1953; Kramp, 1961; Vannucci and Rees, 1961). Bougainvillia vanbenedenii Bonnevie, 1898, has been included as a questionable synonym here following $V$ annueci and Rees (1961), although these authors left open the possibility that Bonnevie's species might be identical with B. superciliaris (L. Agassiz, 1849). However. the 
hydroid of $B$. superciliaris is now known to be stolonal (Werner, 1961: Edwards, 1966a).

Hydroids examined here from Bermuda bear considerable resemblance to the description of Bougainvillia longicirra Stechow, 1914, from the Caribbean. Like B. muscus, Stechow's (1914) colonies were small but often extensively branched, the hydrocaulus was monosiphonic, the perisarc was wrinkled and encrusted with particles of silt and detritus, a pseudohydrotheca was present, and the tentacles numbered about 16. Medusa buds were present on Stechow's hydroids, but the newly liberated medusa was not observed. Fraser (1944) was almost certain that $B$. longicirra was conspecific with $B$. superciliaris, but Vannucci and Rees (1961) correctly disputed this, noting that the latter is a boreal species occurring well to the north of the locality where B. longicirra was found. As noted above, the hydroid of $B$. superciliaris is now known to be stolonal. Stechow (1914) indicated that B. longicirra might represent the hydroid of the medusa $B$. niobe Mayer, 1894. Vannucci and Rees (1961) stated that this was based on surmise, and noted that the type locality of Charlotte Amalie in the West Indies is within range of $B$. frondosa Mayer, $1900 \mathrm{~b}$, as well as that of $B$. niobe. I have not regarded $B$. longicirra as conspecific with $B$. muscus because of a lack of knowledge about its medusa stage.

Medusae described here were isolated and reared in the laboratory following liberation from the hydroid. Specimens were maintained at $28-29^{\circ} \mathrm{C}$ in covered fingerbowls containing natural seawater, and fed pieces of newly hatched nauplii of Artemia several times daily. Observations were made on both living and preserved material. Sexual maturity was attained about three days after liberation, when eggs were observed being shed from the gonads of female medusae; none of the medusae reared to maturity were male. The eggs were surrounded by an envelope containing nematocysts, as reported previously for this species (Russell, 1953). Of several dozen medusae isolated initially, none survived longer than 3.5 days in the laboratory. A short life span in medusae of this species might partly explain Russell's (1953) observation that they are scarce in the plankton around the British Isles, considering the abundance of the hydroid there.

Neither hydroid nor medusa of Bongainvillia muscus has been reported previously from Bermuda, but two other species of medusae belonging to this genus have been reported from the area. Bigelow $(1918,1938)$ identified $B$. niobe in collections of hydromedusae from Bermuda, and Moore (1949) noted that the species was an abundant winter form there. Bougaimillia platygaster (Haeckel, 1879) has been recorded from a number of areas in the western North Atlantic, including the Sargasso Sea near Bermuda (Kramp, 1959).

\section{KNOWN RANGE}

Bermuda: first record.

Elsewhere: western Atlantic (Mayer, 1910, as B. autumnalis); eastern Atlantic (Russell, 1953); Indian Ocean (Millard, 1975); western Pacific (Yamada, 1959).

\section{Family Cytaeididae L. Agassiz, 1862}

Cytaeidae L. Agassiz, 1862:341 lemended to Cytaeididae by Kramp, 19611.

\section{DIAGNOSIS}

Hydroid colonies stolonal; hydranths arising from a creeping hydrorhiza. Perisarc covering hydrorhiza, terminating at base of hydranths, often in form of a collar. Hydranths columnar; tentacles filiform, in one more or less regular oral whorl; hypostome conical.

Gonophores free medusae or fixed sporosacs, arising from hydrocaulus on stalks. Medusa bell-shaped; manubrium bulbous, with simple, circular mouth and four or more unbranched oral tentacles inserting above mouth. Radial canals four. Marginal tentacles solid, four or exceptionally eight, each arising from a tentacle bulb. Ocelli absent. Gonads on manubrium.

\section{REMARKS}

Rees (1962) recognized three genera of hydroids in the family Cytaeididae L. Agassiz, 1862. All species having free medusae were included in Cytaeis Eschscholtz, 1829. Species with fixed gonophores were placed in Perarella Stechow, 1922, except for the poorly known Stylactis vermicola Allman. 1888, which was retained in Stylactella Haeckel, 1889.

The diagnosis of the family Cytaeididae given here encompasses the recently described Paracytaeis Bouillon, 1978a, but excludes Cnidostoma Vanhöffen, 1911, following Picard (in Kramp, 1961:444) and Rees (1962).

Haeckel (1889) believed that Stylactella, Stylactis Allman, 1864a, and Hydranthea Hincks, 1868, were related genera, and stated, "Perhaps Stylactella and the allied genera may represent together a distinct family, the Stylactidae." Although the poorly known genus Stylactella is apparently a cytaeid, the nominal family Stylactidae is not a synonym of the Cytaeididae, as implied by Rees (1962). The name Stylactidae is derived from the nominal genus Stylactis rather than Stylactella, and the former is therefore type genus of the family [Art. 63]. The nominal genus Stylactis, and Haeckel's Stylactidae, are included 
here in the Hydractiniidae L. Agassiz, 1862. Hydranthea is now included in the family Haleciidae Hincks, 1868 (e.g., see Cornelius, 1975; Bouillon, 1985).

\section{Genus Cytaeis Eschscholtz, 1829}

Cytaeis Eschscholtz, 1829:104.

Cytacis de Blainville, 1834:284 [incorrect subsequent spelling].

Cyteis van Beneden, 1867:18 [incorrect subsequent spelling]. Cytheis van Beneden, 1867:18 [incorrect subsequent spelling].

Nigritina Haeckel, 1879:73.

Cytacidium Haeckel, 1879:75.

Cytaesis Bouillon, 1978a:129 [incorrect subsequent spelling].

\section{DIAGNOSIS}

Hydroids with characters of the family.

Gonophores free medusae, arising on stalks from hydrorhiza. Medusa with characters of the family, with only four marginal tentacles.

\section{TYPE SPECIES}

Cytaeis tetrastyla Eschscholtz, 1829, by monotypy.

\section{REMARKS}

Haeckel (1879) established two subgenera within the genus Cytaeis Eschscholtz, 1829, Nigritina for those species lacking a gastric peduncle and Cytaeidium for those having a peduncle. He attributed Nigritina to J. Steenstrup, but apparently the name was derived from an unpublished manuscript by that author. Neither nominal subgenus is recognized in the recent literature on Cytaeis (e.g., Kramp, 1959, 1961, 1965; Rees, 1962; Uchida, 1964; Vervoort, 1967; Millard, 1975; Hirohito, 1977; Bouillon, 1978a, 1980, 1985). Kramp (1961) regarded Cytaeis pusilla $\mathrm{Ge}-$ genbaur, 1857, type species of Cytaeidium, as doubtfully conspecific with Cytaeis tetrastyla Eschscholtz, 1829.

Mayer (1910) included the nominal genus Cubogaster Haeckel, 1879 (original spelling Cybogaster Haeckel, 1864), in the synonymy of Cytaeis. However, Cybogaster gemmascens Haeckel, 1864, type species of Cybogaster by monotypy, was regarded by Russell (1953) as conspecific with Lizzia blondina Forbes, 1848, type species of the bougainvilliid genus Lizzia Forbes, 1846. Thus, neither Cybogaster nor its junior objective synonym Cubogaster [Art. 33a (ii)] can be regarded as synonymous with Cytaeis.

Stylactella Haeckel, 1889, and Perarella Stechow, 1922, are distinguished from $C y$ taeis largely by the type of gonophore produced (Rees, 1962), a practice criticized by Petersen (1979). However, the relationships of these nominal genera are unclear and they have not been combined here.
Komai (1931) was the first to link hydroid and medusa stages of Cytaeis, working with what he thought was $C$. japonica Uchida, 1927. Rees (1962) regarded Komai's hydrozoan as a distinct species and named it $C$. whidae.

Worldwide, three nominal species of $C y t a e i s$ medusae were listed by Kramp (1961). Six species, including the hydroids of five of these, were included in the genus by Rees (1962). Rees suggested that more than one species may have been combined under $C$. tetrastyla by Kramp (1961).

\section{Cytaeis sp.}

Figs. 21, 22

\section{MATERIAL EXAMINED}

Green Bay, Harrington Sound, on shell of Cerithium litteratum from Cladophora bed, $-2.5 \mathrm{~m}, 21$ September 1984. one colony, with medusa buds, two medusae liberated in laboratory from hydroid, Romiz B353.

\section{DESCRIPTION}

Colony stolonal, with hydrorhizal network adhering to gastropod shell. Perisarc smooth, thin, terminating at base of hydranth, not dilated in form of cup-shaped collar. Spines absent. Hydranths all gastrozooids, clavate to nearly columnar, up to $0.6 \mathrm{~mm}$ long, $0.2 \mathrm{~mm}$ wide, with four to five tentacles in each of two closely placed oral whorls, those of one whorl alternating with those of adjacent whorl. Tentacles filiform, but with nematocyst batteries arranged in more or less distinct rings medially and distally. Hypostome dome-shaped.

Nematocysts-

Hydroids: desmonemes $5.0-5.8 \mu \mathrm{m} \times 3.3-3.8 \mu \mathrm{m}$; heterotrichous microbasic euryteles $7.4-8.3 \mu m \times 3.5-$ $3.8 \mu \mathrm{m}$.

Medusa buds pear-shaped to globular, arising singly on relatively long stalks from hydrorhiza, completely invested in perisarc. Newly liberated medusae bell-shaped, about $0.4 \mathrm{~mm}$ high and wide; mesoglea thin. Exumbrella with four distinct perradial longitudinal furrows and four less distinct interradial furrows in preserved and contracted material; scattered exumbrellar nematocysts present. Manubrium tubular to somewhat fusiform, extending about halfway to velar opening; mouth simple; oral tentacles four, unbranched, inserted just above mouth. each with a small terminal cluster of nematocysts. Radial canals four: narrow ring canal present. Tentacle bulbs four, perradial. subspherical, each with a single contracted filiform tentacle. Ocelli absent. Gonads undeveloped.

\section{REMARKS}

Th:s hydrozoan cannot be assigned at present, with any degree of confidence, to any of the nominal species cur- 

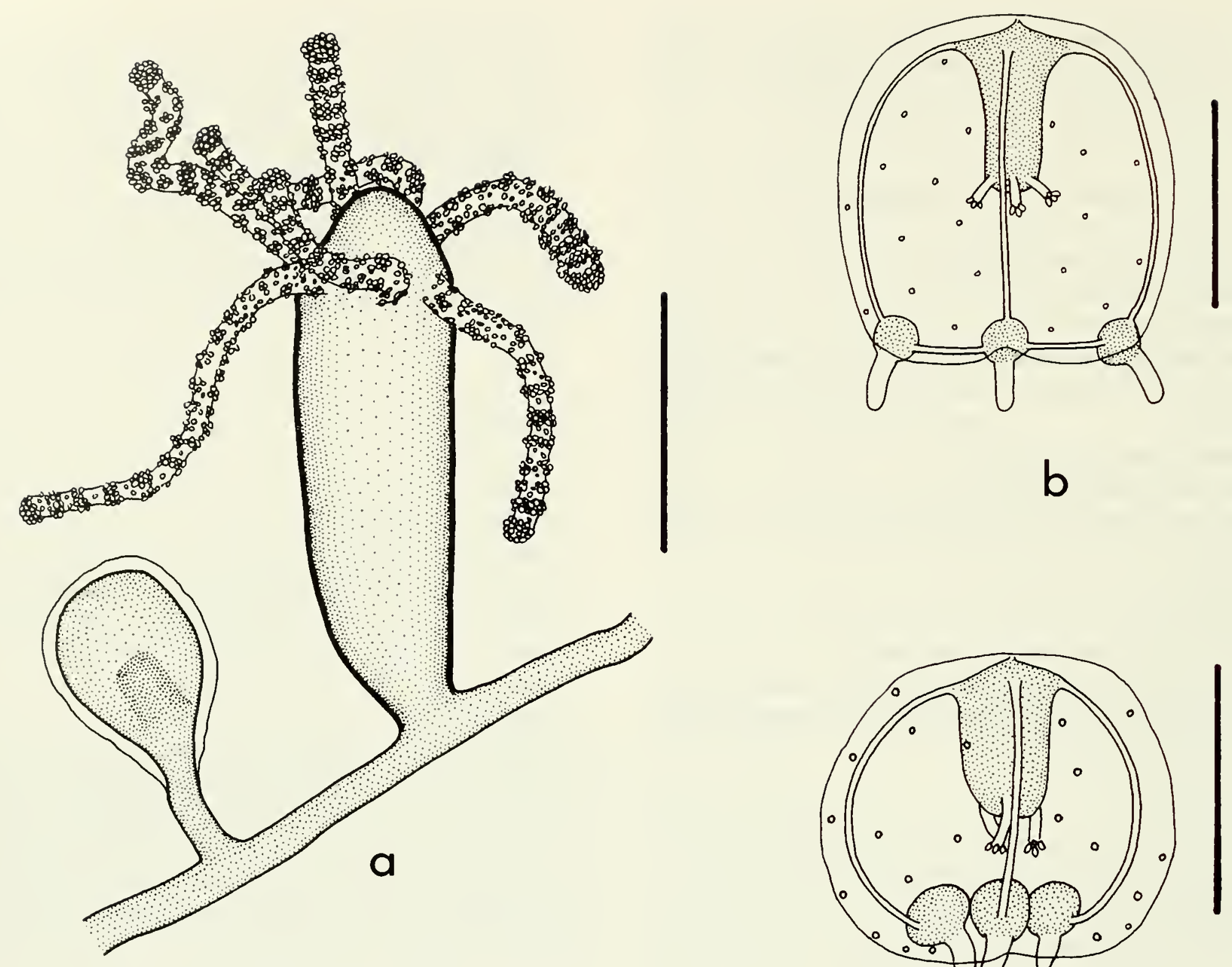

b

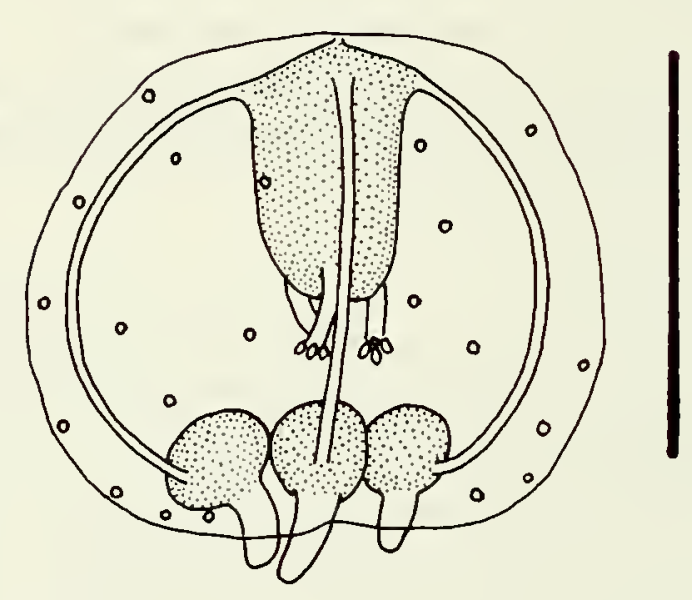

C

FIG. 21. Cytaeis sp., ROMIz B353. Scales equal $0.25 \mathrm{~mm}$. $a$, Hydranth and gonophore. $b$, Newly liberated, living medusa. c, Newly liberated, preserved medusa.

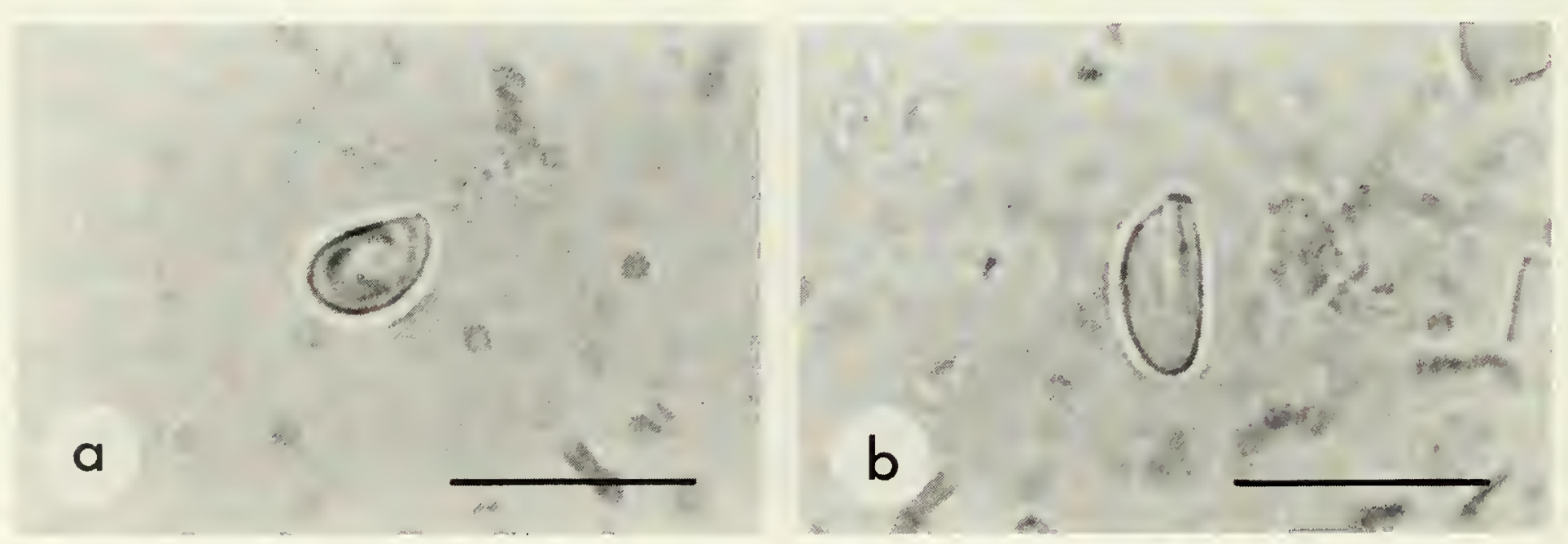

FIG. 22. Cytaeis sp., nematocysts of hydranth, Romiz B353. Scales equal $10 \mu \mathrm{m}$. $a$, Desmoneme. $b$. Heterotrichous microbasic eurytele. 
rently referred to Cytacis Eschscholtz, 1829. While bearing considerable resemblance to C. nassa (Millard, 1959a), Bermuda specimens have not been referred to that species for several reasons. First, hydranths were smaller than those of C. nassa described by Vervoort (1967) and Millard and Bouillon (1973), and much smaller than those measured by Millard (1959a) and Rees (1962). Admittedly, hydranth measurements in the literature on C. nassa are quite varied, and differences noted here may be taxonomically insignilicant. Secondly, Millard (1959a) reported that young hydranths of $C$. nassa had 8 tentacles in a single verticil, while older ones had 16 tentacles in two alternating verticils. The smaller hydranths of $C$ vtaeis sp. studied here had 4 to 5 tentacles in each of two closely placed whorls. This seeming difference may also be taxonomically unimportant, because Vervoort's (1967) material of $C$. nassa had 4 tentacles per whorl on the majority of hydranths. Finally, the manubrium of the young medusa in present collections was proportionately smaller than that described or illustrated in C. nassa by Millard (1959a, 1975), Rees (1962), and Millard and Bouillon (1973). As in $C$. niotha (Pennycuik, 1959), an inadequately known nominal species from Australia, hydranths of $C$. nassa appear to have been substantially larger than those of Bermudian specimens. Gonophores of $C$. niotha, although arising from the hydrorhiza, were unlike my material in being clustered around the bases of the hydranths. Stylactis indica Stechow, 1920, referred to Cytaeis by Rees (1962), is likewise poorly known; questions remain as to the nature of its gonophores and to its generic identity. Bermuda specimens differ from $C$. uchidae Rees, 1962, and C. muda Rees, 1962, in having undeveloped instead of developed gonads in the newly liberated medusa. My material is similar to descriptions of $C$. imperialis Uchida, 1964, from Japan, but has not been identified as that species largely on zoogeographic grounds. ROM specimens may well belong to Cytaeis tetrastyla Eschscholtz, 1829, an epipelagic medusa known to occur near Bermuda (Bigelow, 1918). However, such an identification cannot be established at present because of lack of information on the life cycle of C. tetrastyla. Rearing of the medusa of Bermudian material will likely be necessary to ascertain whether it belongs to any of the previously named species of Cytaeis, or to an undescribed species.

The status of the various nominal species of Cytaeis is in need of clarification. Confusion exists in particular over $C$. japonica Uchida, 1927. 1t seems uncertain whether $C$. japonica is identical with $C$. uchidae (alternative spelling C. uchidai, as emended by Kramp, 1965). Rees (1962) believed that the two were distinct, while Uchida (1964) regarded them as conspecific. If they are conspecific, the specific name japonica has priority [Art. 23] and cannot be abandoned in favour of the name uchidae, as proposed by Uchida (1964). The name $C$. japonica originally encompassed at least two and possibly three different species of medusae. Uchida (1930) realized that what he originally thought (Uchida, 1927) was the young medusa with medusa buds of $C$. japonica was identical with Podocoryna simplex Kramp, 1928, instead. In addition, he later indicated (Uchida, 1964) that the name $C$. japonica encompassed $C$. imperialis as well. Kramp $(1961,1965)$ regarded $C$. japonica as a synonym of $C$. tetrasty/a. Further research is needed to clarify the relationships of the Japanese species of Crtaeis.

Hydroids of the genus Cytaeis have not been reported before from Bermuda.

\section{Family Hydractiniidae L. Agassiz, 1862}

Hydractinidae L. Agassiz, 1862:339 [emended to $\mathrm{Hy}$ dractiniidae by Hincks, 1868:18].

Podocorynidae Allman, 1864a:353.

Stylactidae Haeckel, 1889:79.

Janariidae Stechow, 192lb:29.

\section{DIAGNOSIS}

Hydroid colonics stolonal. Hydrorhiza consisting of tubes covered with chitinous perisarc, or an encrustation of naked coenosarc with or without a calcareous skeleton, frequently with spines, less frequently with calcareous branches. Hydranths sessile, naked, polymorphic, as gastrozooids, gonozooids, and occasionally dactylozooids. Gastrozooids of one or more types, usually with one or more close whorls of filiform tentacles encircling a conical to clubshaped hypostome; gonozooids with or without filiform tentacles; dactylozooids elongate, lacking tentacles.

Gonophores fixed sporosacs or free medusae, usually borne on gonozooids. Medusa well developed to degenerate, more or less bell-shaped. Manubrium tubular to sacshaped, with or without a peduncle: rim of manubrium tubular or with four branched or unbranched lips, having terminal batteries of nematocysts; mouth present or absent. Radial canals four. Marginal tentacles solid, four, eight, or more. Ocelli present or absent. Gonads on manubrium, sometimes extending along proximal portions of radial canals.

\section{REMARKS}

Rees (1962) provided the first clear distinction between hydroids of the closely related families Hydractiniidac L. Agassiz, 1862, and Cytacididac L. Agassiz, 1862. Ac- 
cording to his diagnosis, followed here, cytaeid hydroids differ from hydractiniids in completely lacking spines on the hydrorhiza, and in having gonophores on the hydrorhiza instead of on gonozooids. The status of the nominal fanily Stylactidae Hacckel, 1889, referred to the Hydractiniidae here, is discussed under the family Cytaeididae elsewhere in this report (see pp. 28-29).

Bouillon (1978b) briefly discussed the Hydractiniidae, including it together with the families Stylasteridae Gray. 1847. Ptilocodiidae Coward, 1909, and Rhysiidae Brinckmann, 1965, in a newly recognized superfamily Hydractinioidea L. Agassiz. 1862 [Art. 36].

Generic limits within the Hydractiniidae are problematic (Motz-Kossowska, 1905; Goette, 1916; Stechow, 1923a; Kramp. 1932; Iwasa, 1934: Rees, 1962: Bouillon, 197I, 1985; Millard, 1975). Stechow (1923a), for example, recognized 14 recent (nonfossil) genera in his classification of the subfamily Hydractiniinae. In a re-examination of Stechow's classification, Kramp (1932) included no more than five of these in the group: he combined seven within Hydractinia (Halerella Stechow, 1922, Stvlactis Allman, 1864a, Cionistes Wright, 1861, Podocoryna M. Sars, 1846 , Hydronema Stechow. 1921a, Hydractinia van Beneden, 1841, and Hydrissa Stechow, 1921a), excluded four from discussion (Clavactinia Thornely, 1904, Rhizohydra Cope, 1884. Hydrocorella Stechow, 1921b, and Hydractomma Stechow, 1921a), and dismissed the remaining three as pandeids (Perigonella Stechow, 1921c, Podocorella Stechow, 192lc, and apparently Clavopsis Gracffe, 1883). Kramp recognized two subgenera, Hydractinia and Stylactis, within the genus Hydractinia. More recently, Bouillon (1985) included the nominal genera Clavactinia, Hansiella Bouillon, 1980, Hydractinia, Hydrocorella, Janaria Stechow, 1921 b, Kinetocodium Kramp, 1921, Podocoryna (as Podocoryne; but Podocoryne is an incorrect subsequent spelling of Podocoryna, lirst used by Lütken, 1850). Stylactis, and Tregoubovia Picard, 1958, in the Hydractiniidae. Kinetocodium possesses characters of both the Hydractiniidae and the Cytaeididae, and its systematic position is unclear at present. Stylactis is a synonym of Hydractinia, as noted by Stechow (1923a) and others, and Stylactis auct., to which Bermuda material belongs, is replaced here by Stylactaria Stechow, 1921a. Much confusion remains at the generic level within this family, and taxonomic revision is badly needed.

\section{Genus Stylactaria Stechow, 1921a}

Stylactaria Stechow, 1921a:250.

DIACNOSIS

Hydractiniidae with reticular hydrorhiza; hydrorhizal stolons covered with perisarc; hydrorhiza not encrusting, nor covered with naked coenosarc, nor forming a calcareous skeleton. Hydrorhizal spines present or absent. Hydranths typical of the family.

Gonophores fixed sporosacs or free but degenerate medusae, borne on gonozooids beneath whorl of oral tentacles; newly liberated medusa sac-shaped. Manubrium simple, tubular, without mouth, oral lips, or oral tentacles. Tentacles 8 to 10 in number, rudimentary. Radial canals four. Ocelli absent. Gonad surrounding manubrium.

\section{TYPE SPECIES}

Stylactis inermis Allman, 1872, by monotypy.

\section{REMARKS}

The nominal genus Stylactis Allman, 1864a, was constituted to accommodate two species, Podocornne sarsii Steenstrup, 1850, and Podocoryna fucicola M. Sars, 1857. A retiform hydrorhiza, consisting of anastomosing tubes covered with perisarc, was regarded as diagnostic of the genus (Allman, 1864a). Bonnevie (1898) discovered that the hydrorhiza in type material of $P$. sarsii was encrusting and covered with naked coenosarc. She did not, as suggested by Iwasa (1934) and others, mention examining material of $P$. fucicola as well. However, the hydrorhiza of $P$. fucicola also appears to be encrusting with naked coenosarc (see Castric-Fey, 1970). I concur with Goette (1916), Stechow (1923a), Iwasa (1934), and others that these two species, with their encrusting hydrorhizae, are best referred to the genus Hydractinia van Beneden, 1841 . The type species of Stylactis must be one of these two originally included species [Art. 69], not one subsequently referred to the genus such as Stylactis inermis Allman, 1872 (see Millard, 1975). Mayer (1910) designated $P$. fucicola (misspelled as Stylactis fuciola) type species of Stylactis. Podocoryna fucicola is referred to Hydractinia (e.g., see Stechow, 1923a; Iwasa, 1934; Castric-Fey, 1970), and the name Stylactis is a junior subjective synonym of Hydractinia, as noted earlier by Stechow (1923a).

Stechow (1923a) suggested, incorrectly, that the name Stylactella Haeckel, 1889, be used for species of Stylactis auct. Three nominal species were originally included in Stylactella by Haeckel (1889), S. abyssicola Haeckel, 1889 , S. spongicola Haeckel, 1889, and S. vermicola Allman, 1888. Gonophores in all three reportedly arise from the hydrorhiza and not from gonozooids (Allman, 1888; Haeckel, 1889; Iwasa, 1934; Rees, 1962); they should be included in the family Cytaeididae rather than in the Hydractiniidae (Rees, 1962). Thus, the name Stylactella cannot replace Stylactis auct., species of which have gonophores on gonozooids. Rees (1962) regarded Stylactella as an insufficiently described genus of cytaeid, and included $S$. vermicola as its type and only known species. He transferred both $S$. spongicola and S. abyssicola to Perarella Stechow, 1922, also included in the family Cytaeididae. 
Stechow (1921a) proposed that the new name Stylactaria be applied to those species of Stylactis auct. with gonophores on gonozooids, if such hydroids were to be recognized as a distinct genus, and designated Stylactis inermis Allman, 1872, as type species of the genus. Stylactaria is recognized here as the valid name of the genus. Stylactaria inermis reportedly produces fixed sporosacs (Bouillon, 1971), while some species of Stylactis sensu Mayer (1910) may liberate degenerate medusae. Given the variation of gonophore development among species of the group, a separate genus for those liberating a degenerate medusa seems unjustified.

Stechow (1923a) included the nominal genus Clavopsis Graeffe, 1883, characterized by the presence of free but degenerate medusae, in the Hydractiniidae L. Agassiz, 1862. He believed that Stylactis sensu Mayer (1910) corresponded with that nominal genus. However, Graeffe's account of the type species of Clavopsis, C. adriatica Graeffe, 1883, was of a hydroid that was more likely a pandeoid or possibly a bougainvillioid than a hydractiniid. The hydranth pedicel of $C$. adriatica was enveloped in thin perisarc, and there was no clear evidence given of polymorphism in the species. Clavopsis is certainly not a synonym of Stylactis sensu Mayer (1910), and hence not of Stylactaria either.

Stylactaria differs from Hydractinia, Podocoryna M. Sars, 1846, Clavactinia Thornely, 1904, Hydractomma Stechow, 1921a, and Hydrissa Stechow, 1921a, in having a reticular, nonencrusting hydrorhiza devoid of naked coenosarc. The hydrorhiza does not form a calcareous skeleton, as in Hydrocorella Stechow, $192 \mathrm{lb}$, and Janaria Stechow, 1921b. Unlike Podocoryna, which liberates a well-developed medusa, Stylactaria has fixed gonophores or a degenerate, short-lived medusa. Stylactaria differs from Kinetocodium Kramp, 1921, in having well-developed instead of reduced oval tentacles, and gonophores arising from gonozooids rather than from the hydrorhiza.

Species assigned to Stylactaria here, in addition to $S$. inermis, are $S$. arge (Clarke, 1882), S. arctica (Jäderholm, 1902), S. ingolfi (Kramp, 1932), S. pisicola (Komai, 1932), S. yerii (Iwasa, 1934), S. carcinicola (Hiro, 1939), and S. claviformis (Bouillon, 1971). I have not included $\mathrm{Hy}$ dractinia pruvoti Motz-Kossowska, 1905, in the genus because of its hydrorhiza, which is encrusting rather than reticular. Moreover, its medusa is campanulate instead of sac-shaped, and four tentacles are present instead of eight. It was included by Stechow (1921a) as the only species in his new genus Hydractomma.

\section{Stylactaria arge (Clarke, 1882), comb. nov.}

Figs. 23, 24

Stylactis arge Clarke, 1882:135; pl. 8, figs. 18-20.

Sytlactis arge Clarke, 1882:138 [lapsus].
Stylactis hooperii Sigerfoos, 1899:802; figs. 1-5.

Stylactis hooperi-Hargitt, 1901a:311 [incorrect subsequent spelling].

Stylactis hoopei-Komai, 1932:451 [incorrect subsequent spelling].

Stylactis sp. Crowell, 1947:206

Hydractinia arge - Calder, 1971:31; pl. 2, fig. B; pl. 7, fig. A.

Styllactis hooperi var. minor Wedler and Larson, 1986:94; fig. 10c [incorrect subsequent spelling].

\section{TYPE LOCALITY}

Crisfield, Maryland, on Chesapeake Bay, United States.

\section{MATERIAL EXAMINED}

Green Bay, Harrington Sound, on shell of Cerithium litteratum from Cladophora bed, $-2 \mathrm{~m}, 11$ July 1983, I colony, with gonozooids and male gonophores, two medusae liberated in laboratory from hydroid, ROMIZ B354. Green Bay, Harrington Sound, on shells of C. litteratum from Cladophora bed, -3 m, 11 July 1983, 2 colonies. one male and one female, with gonozooids and gonophores, ROMIz B355. Green Bay, Harrington Sound, on shells of $C$. litteratum from Cladophora bed, $-1.5 \mathrm{~m}$, 27 June 1983, 13 colonies, with gonozooids and gonophores, ROMIZ B356. Green Bay, Harrington Sound, on shells of $C$. litteratum from Cladophora bed, $-3 \mathrm{~m}, 4$ October 1986, 2 colonies, with gonozooids and gonophores, ROMIZ B367.

\section{DESCRIPTION}

Colony stolonal, with branching and anastomosing hydrorhizal stolons adhering to gastropod shell. Perisarc thin, smooth or with irregular wrinkles, terminating at base of hydranth, not dilated as cup-shaped collar. Spines chitinous, simple, inconspicuous in unstained material, up to $0.3 \mathrm{~mm}$ high, arising from hydrorhizal stolons. Polyps of two types, gastrozooids and gonozooids. Gastrozooids contractile, variable in shape but generally clavate, up to $2 \mathrm{~mm}$ high, $0.3 \mathrm{~mm}$ wide, somewhat bulbous and rugose beneath tentacular whorl, slightly to distinctly constricted at insertion with hydrorhiza. Tentacles filiform, 8 to 16 in number on fully developed gastrozooids, in two closely placed whorls, those of upper whorl held somewhat more erect than those of lower whorl in life. Hypostome domeshaped to clavate to knob-shaped. Gonozooids columnar, contractile, up to $1.7 \mathrm{~mm}$ high, $0.2 \mathrm{~mm}$ wide; region beneath tentacular whorl smooth and slender. Tentacles filiform, 5 to 10 in number, in one whorl. Medusa buds arising proximal to tentacular whorl, usually with two buds on opposite sides of gonozooid. Hypostome bulbous to dome-shaped. Sexes separate.

Nematocysts-

Gastrozooids: desnonemes 5.0-5.7 $\mu \mathrm{m} \times 2.8-3.3 \mu \mathrm{m}$; 


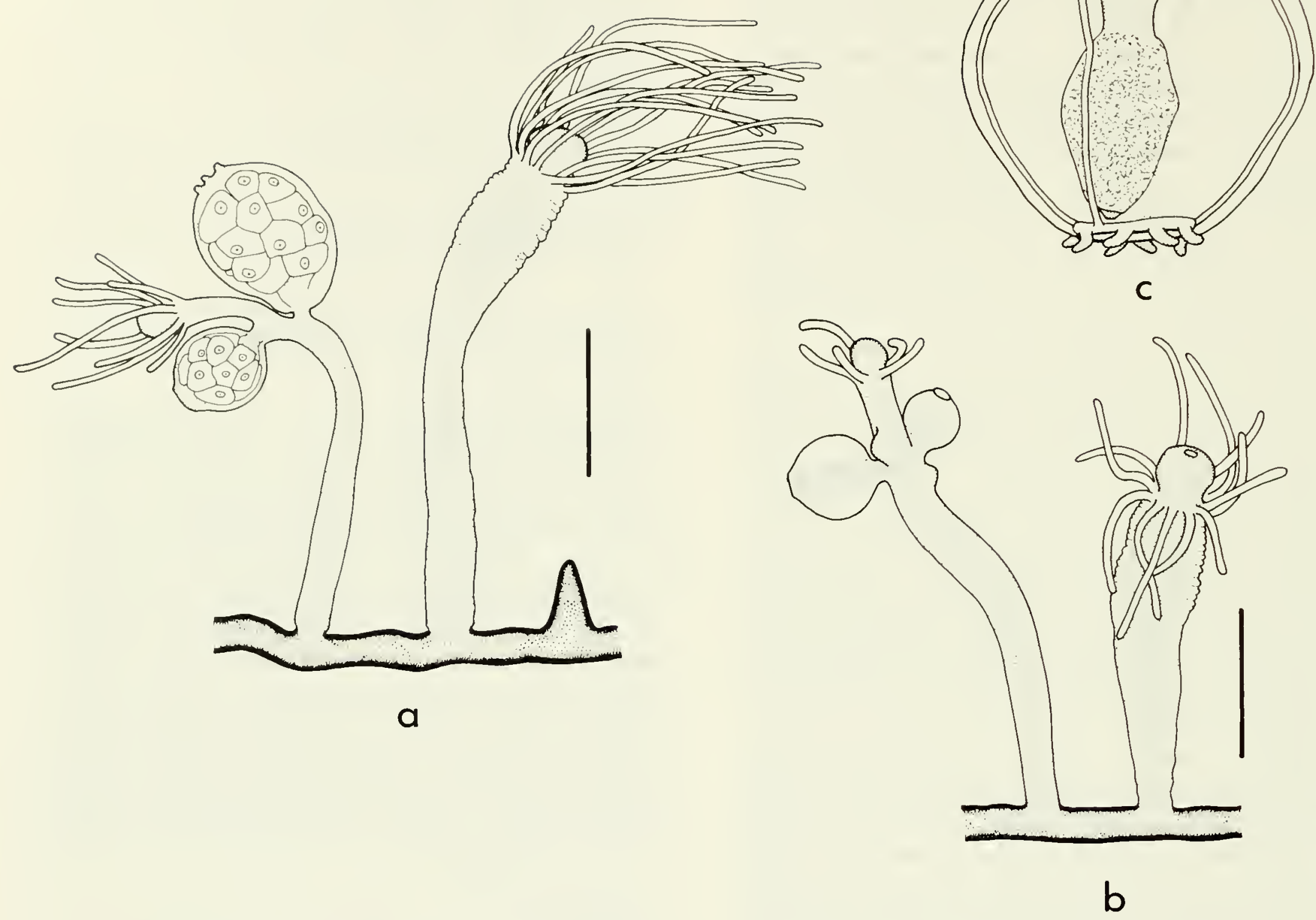

FIG. 23. Stylactaria arge. Scales equal $0.5 \mathrm{~mm}$. a, Gastrozooid, and gonozooid with female medusa buds. Romiz B355. b, Gastrozooid, and gonozooid with male medusa buds, Romiz B354. $c$, Male medusa, one to two hours old, ROMIZ B354.
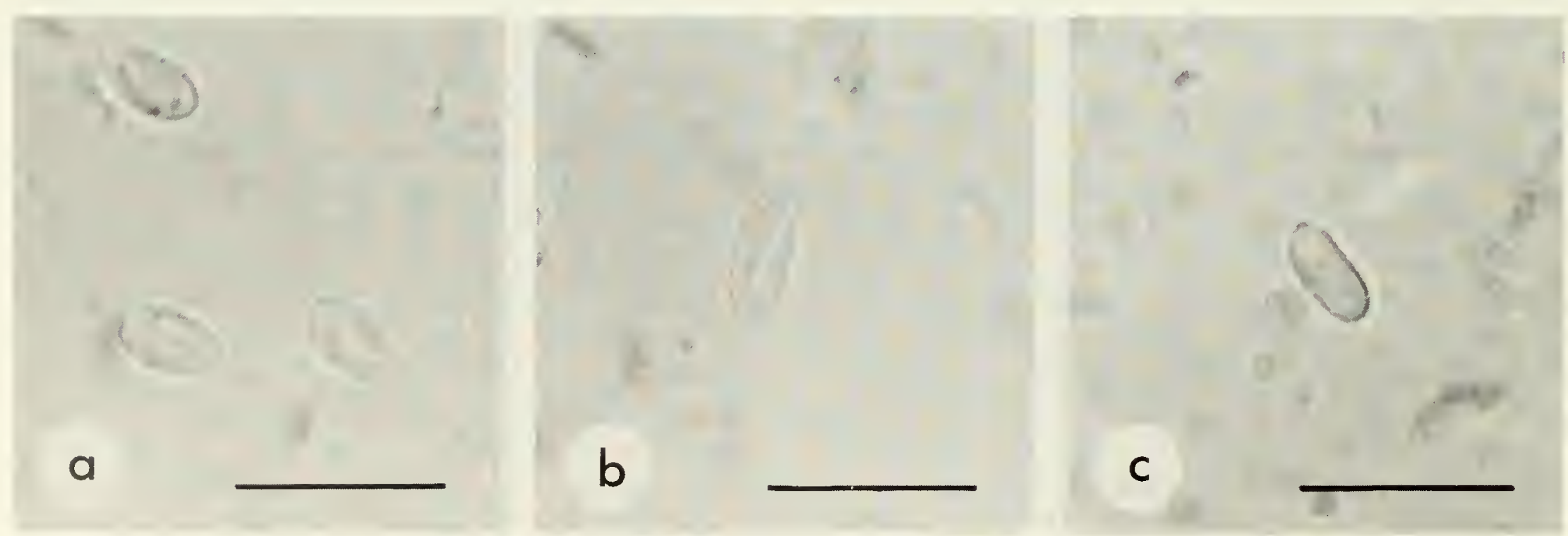

FIG. 24. Stylactaria arge, nematocysts of gastrozooid and gonozooid. Scales equal $10 \mu \mathrm{m}$. $a$, Desmonemes of gastrozooid, ROMIz B354. b. Heterotrichous microbasic curytelc of gastrozooid, RoMIz B354. $c$, Haploneme of gonozooid, ROMIZ B367. 
heterotrichous microbasic euryteles $7.3-7.8 \mu \mathrm{m} \times 2.6-$ $2.8 \mu \mathrm{m}$.

Gonozooids: desmonemes 5.5-6.5 $\mu \mathrm{m} \times 3.0-3.8 \mu \mathrm{m}$; haplonemes 4.9-6.6 $\mathrm{m} \times 2.4-2.7 \mu \mathrm{m}$; heterotrichous microbasic euryteles $8.3-10.2 \mu \mathrm{m} \times 2.9-3.7 \mu \mathrm{m}$.

Medusa sac-shaped, degenerate, about $1.1 \mathrm{~mm}$ high and $1.2 \mathrm{~mm}$ wide in formalin-preserved specimens; mesoglea thin. Manubrium tubular, extending nearly to velar opening; mouth, oral arms, and oral tentacles lacking. Radial canals four; narrow ring canal present. Tentacles eight in number, rudimentary. Ocelli absent. Gonads encircling manubrium, fully developed prior to liberation of medusa.

Nematocysts-

Medusae: desmonemes 4.8-5.6 $\mu \mathrm{m} \times 2.6-3.0 \mu \mathrm{m}$; heterotrichous microbasic euryteles $5.9-6.9 \mu \mathrm{m} \times 2.4-$ $2.9 \mu \mathrm{m}$.

\section{REMARKS}

Medusae of Stylactaria arge (Clarke, 1882) and S. hooperii (Sigerfoos, 1899) are inseparable from existing descriptions (Clarke, 1882; Sigerfoos, 1899). Accounts of their hydroids differ only in minor respects (Fraser, 1944; Crowell, 1947; Calder, 1971, 1975). From the original descriptions (Clarke, 1882; Sigerfoos, 1899), S. hooperii seems to differ from $S$. arge in having (1) somewhat smaller gastrozooids, (2) gastrozooids that do not reproduce asexually by autotomy, (3) gastrozooid tentacles in a single row rather than in two closely placed whorls, and (4) spines on the hydrorhiza. I have been unable to locate type material of either nominal species for comparison. Apparent differences such as those noted above are interpreted here as nothing more than variation that might be expected within a single species, and $S$. hooperii is regarded here as conspecific with $S$. arge. Both nominal species were originally described from eelgrass beds on the middle Atlantic coast of the United States. Calder (1971, 1975) earlier referred Crowell's (1947) report of Stylactis sp. to this species.

Specimens referred here to Stylactaria arge were less robust than the hydroids described by Clarke (1882) and Sigerfoos (1899), as also were colonies described earlier (ROMIz B666) from Chesapeake Bay (Calder, 1971). There seems little likelihood, from their overall similarity to $S$. arge, that the specimens from Bermuda represent a distinct species. As in material from the United States, medusae were degenerate, short-lived, sexually mature at release, and liberated from the hydroids only at dusk.

\section{KNOWN RANGE}

Bermuda: first record.

Elsewhere: western Atlantic (Calder, 1975).

\section{Superfamily Pandeoidea Haeckel, 1879}

?Trichydridae Hincks, 1868:215.

Tiaridae Haeckel, 1879:40 [invalid name, type genus a junior homonym].

Pandaeidae Haeckel, 1879:46 [emended to Pandeidae by Bigelow, 1913].

Amphinemidae Haeckel, 1879:46.

Protiaridae Haeckel, 1879:46.

Bythotiaridae Maas, 1905:434.

Calycopsidi Mayer, 1910:104.

Stomotocini Cockerell, 1911:79.

Hydrichthyinae Stechow, 1922:142.

?Timoididae Kramp, 1961:138.

Niobiidae Petersen, 1979:133.

Halimedusidae Arai and Brinckmann-Voss, 1980:62.

\section{DIAGNOSIS}

Hydroid colonies stolonal or erect, with a creeping hydrorhiza; some taxa ectoparasitic on fishes and ichthyoparasitic copepods, arising from a basal plate embedded in tissues of host. Perisarc variably developed; pseudohydrothecá present or absent. Hydranths of frec-living forms with a single, oral whorl of filiform tentacles surrounding a conical hypostome; those of parasitic forms elongate. degenerate, lacking tentacles.

Gonophores free medusae, arising from hydrorhiza, hydrocaulus, branches, pedicels, or hydranths. Medusae bellshaped, with or without an apical projection; manubrium quadrate, with or without a peduncle; oral tentacles absent: mouth surrounded by four, or infrequently eight, lips with or without marginal nematocyst batteries. Radial canals four, or infrequently eight; centripetal canals usually absent. Marginal tentacles hollow, two, four, or more, with or without conical basal bulbs. Ocelli present or absent. Gonads on manubrium, extending outwards along radial canals in some species.

\section{REMARKS}

Pelagiana trichodesmiae Borstad and Brinckmann-Voss, 1979, is evidently referable to the superfamily Pandeoidea Hacckel, 1879, but the family to which it should be referred is uncertain at present. Accordingly, only the superfamily for this species is given here.

Classification of the Pandeoidea is based larely on the medusa stage because hydroids of most genera within the 
superfamily are unknown. A thorough revision of the Pandeidae by Hartlaub (1914) improved taxonomic understanding of the family, though he retained the name Tiaridae Haeckel, 1879, for the group. The name Tiaridae Haeckel, 1879, is invalid (Bigelow, 1913) because Tiara Lesson, 1843 , its nominal type genus, is a junior homonym of Tiara Swainson, 1832, a mollusc [Art. 39]. Bigelow's (1913) use of the name Pandeidae for the family has been widely followed in the subsequent literature (e.g., Bigelow, 1918; Russell, 1953; Rees, 1956a; Yamada, 1959; Kramp, 1961; Goy, 1972; Millard, 1975; Petersen, 1979; Arai and Brinckmann-Voss, 1980; Bouillon, 1980, 1985).

Medusa taxonomists have recently recognized that the family Pandeidae, as envisaged earlier this century, encompassed a mixed assemblage of genera. Some authors (e.g., Russell, 1953; Arai and Brinckmann-Voss, 1980) have divided the Pandeidae into a number of subfamilies. Petersen (1979) recognized a group of families, including the Calycopsidae Mayer, 1910, Protiaridae Haeckel, 1879. Pandeidae, and Niobiidae Petersen, 1979, within a superfamily, the Pandeoidea. The Trichydridae Hincks, 1868, and Halimedusidae Arai and Brinckmann-Voss, 1980, were also included in this superfamily by Bouillon (1985). However, if the Trichydridae is included in this taxon, the superfamily name Trichydroidea Hincks, 1868 , would predate the name Pandeoidea Haeckel, 1879 [Arts. 23a, 36]. It seems likely that further refinements to the classification of the group will become necessary as knowledge of these hydrozoans advances.

Stechow (1922) established the subfamily Hydrichthyinae based on the parasitic hydroid genus Hydrichthys Fewkes, 1887. Fraser (1944) recognized the group as a distinct family, the Hydrichthyidae. Millard (1975) included Hydrichthys in the Pandeidae based on the morphology of its medusa stage. Through life-cycle studies, Larson (1982) identified the medusa of a Hydrichthys hydroid as Stomotoca pterophylla Haeckel, 1879, a pandeid. The family-group name Hydrichthyinae is, therefore, included here within the synonymy of the Pandeoidea. Larson (1982) concluded that the genus name Hydrichthys was a synonym of Stomotoca L. Agassiz, 1862, but Arai (in press) disagreed. She noted that medusae of the genus Stomotoca possess two tentacles, whereas immature medusae of Hydrichthys mirus Fewkes, 1887, type species of Hydrichthys, have four tentacles (Fewkes, 1887).

Bouillon (1980) observed that the gonads of Timoides agassizii Bigelow, 1904, arose from the manubrium of the medusa rather than from the radial canals as believed earlier, and placed the family name Timoididae Kramp, 1961 , in synonymy with the Pandeidae.

Hydroids of several pandeoid medusa genera have been placed in the nominal genus Perigonimus M. Sars, 1846. However, Perigonimus is a junior subjective synonym of Bougainvillia Lesson, 1830 (see p. 24).
Genus Pelagiana Borstad and Brinckmann-Voss, 1979

Pelagiana Borstad and Brinckmann-Voss, 1979:1233.

\section{DIAGNOSIS}

Hydroids on planktonic blue-green "algae" (Trichodesmium thiebautii); body globular with conical hypostome. Tentacles filiform, in an oral whorl; tentacular nematocysts arranged in two spiral bands.

Gonophores free medusae, arising from hydranth proximal to tentacular whorl. Young medusa thimble-shaped, with four radial canals. Mouth quadrate, without(?) clusters of nematocysts or oral tentacles. Tentacle bulbs four, triangular, with one opposite pair larger than the other; marginal tentacles two, solitary, filiform, arising from the larger pair of tentacle bulbs. Ocelli absent. Adult medusa unknown.

\section{TYPE SPECIES}

Pelagiana trichodesmiae Borstad and Brinckmann-Voss, 1979, by original designation.

\section{REMARKS}

Borstad and Brinckmann-Voss (1979) tentatively referred their nominal genus Pelagiana to the family Pandeidae Haeckel, 1879. They noted that the young medusa of $P$. trichodesmiae Borstad and Brinckmann-Voss, 1979, type species of the genus, resembles the Pandeidae in having large, triangular tentacle bulbs, filiform tentacles, four radial canals, and a four-cornered mouth. The hydroid also has a number of characters found in pandeids: it is monomorphic, and it has a single whorl of filiform tentacles and a conical hypostome. Nevertheless, the systematic position of this species is uncertain because its medusa has yet to be reared to maturity, and in the absence of more detailed information it is referred here only to the superfamily Pandeoidea.

Borstad and Brinckmann-Voss (1979) observed that pandeid medusae undergo considerable morphological change during development, and suggested that life-cycle studies may demonstrate that this hydrozoan belongs to a species that is already known.

\section{Pelagiana trichodesmiae Borstad and Brinckmann-Voss, 1979}

Figs. 25, 26

Pelagiana trichodesmiae Borstad and Brinckmann-Voss, 1979: 1233; figs. 1-3 [hydroid and young medusa].

\section{TYPE LOCALITY}

Barbados, West Indies. 


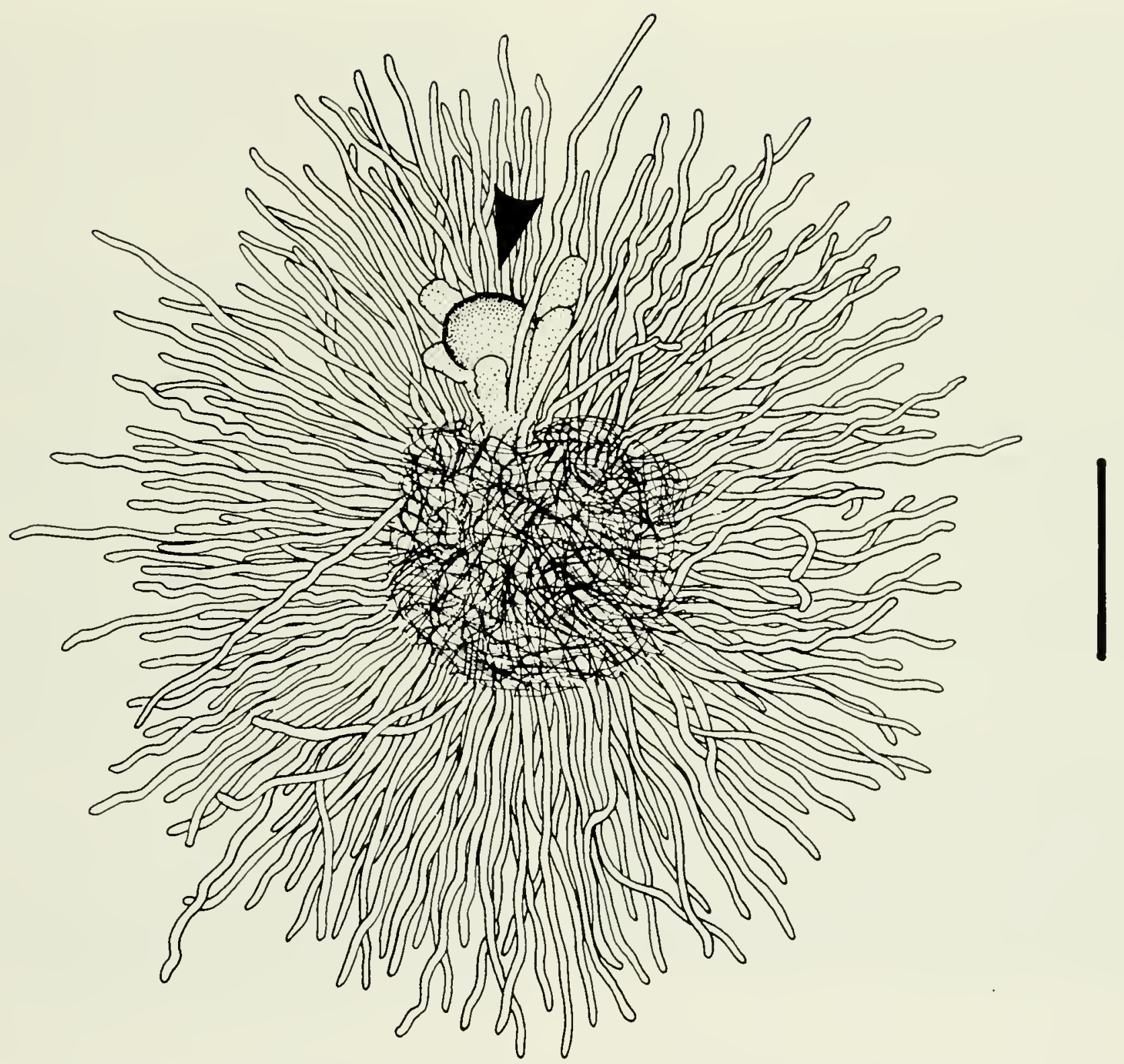

FIG. 25. Pelagiana trichodesmiae, hydroid on clump of Trichodesmium thiebautii, ROMIz B352. Scale equals $0.25 \mathrm{~mm}$.
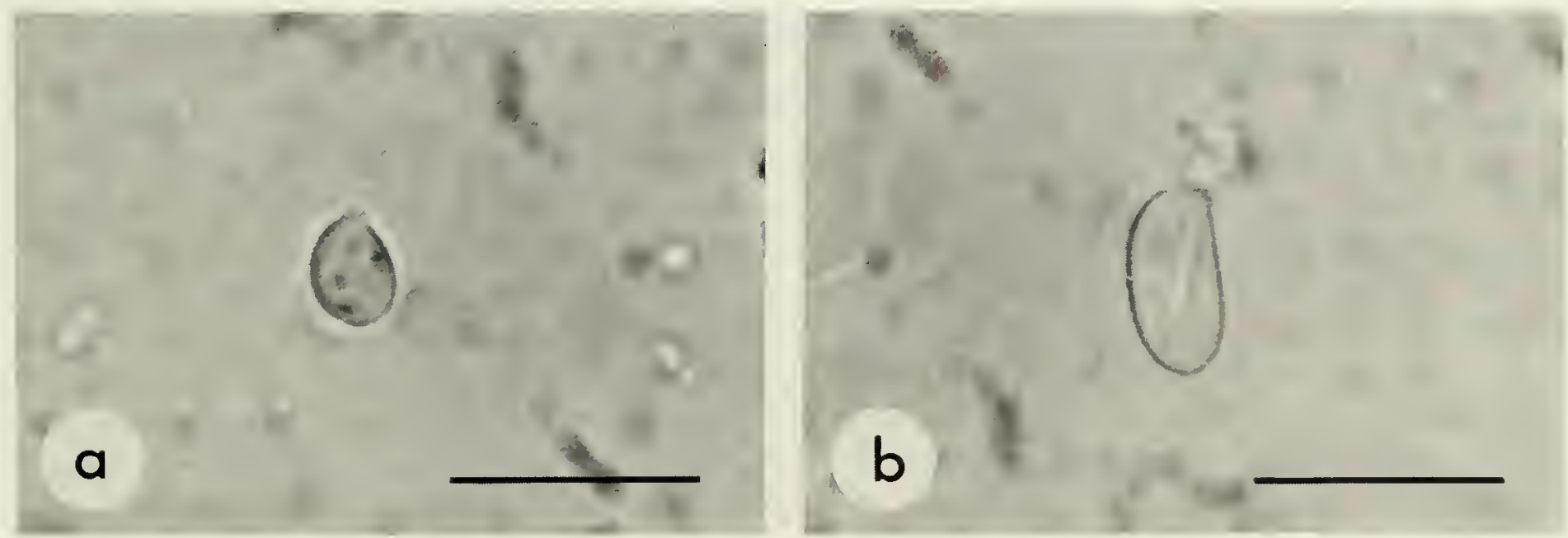

FIG. 26. Pelagiana trichodesmiae, nematocysts of hydranth, Romiz B352. Scales equal $10 \mu \mathrm{m} . a$, Desmoneme. $b$, Heterotrichous microbasic eurytele. 


\section{MATERIAL, EXAMINED}

Atlantic Ocean, $6 \mathrm{~km}$ southwest of Gibbs Hill lighthouse, on Trichodesmium thicbantii, $-1 \mathrm{~m}, 3$ October 1984, two colonies. $0.3 \mathrm{~mm}$ high, without gonophores, ROMIZ B352.

\section{DESCRIPTION}

Hydroids minuscule, inconspicuous, solitary or forming stolonal colonies of a few hydranths; hydrorhiza with thin perisarc, embedded in filamentous tufts of planktonic Trichodesminm thicbantii. Hydranths sac-shaped to pearshaped, up to $345 \mu \mathrm{m}$ high, $195 \mu \mathrm{m}$ wide, constricted at juncture with hydrorhiza. Tentacles four to five in number, filiform, in an oral whorl. Hypostome relatively large, dome-shaped, with terminal mouth.

Gonophores not seen.

Nematocysts-

Hydroids: desmonemes 4.6-5.2 $\mu \mathrm{m} \times 3.4-3.8 \mu \mathrm{m}$ : heterotrichous microbasic euryteles $6.8-7.9 \mu \mathrm{m} \times 3.0_{-}$ $4.0 \mu \mathrm{m}$.

\section{REMARKS}

Geiselman (1977) collected hydroids of this species in plankton samples from the subtropical Atlantic, but did not name them. Borstad and Brinckmann-Voss (1979) described and named Pelagiana trichodesmiae from material collected at Barbados. Its hydroid has been reported only on Trichodesmium thiebantii, an oceanic blue-green "alga."
Borstad and Brinckmann-Voss (1979) described the medusa of Pelagiana trichodesmiae from a single specimen newly liberated from its hydroid, and did not find this stage in the plankton. Clarification of the possible synonymy of this species awaits the rearing of its medusa to a more advanced stage.

Although the hydroid of Pelagiana trichodesmiae is inconspicuous and poorly known, it appears to be relatively common. Geiselman (1977) found it in about 40 per cent of her near-surface collections of Trichodesminm thiebautii from the subtropical North Atlantic. Borstad and Brinckmann-Voss (1979) found it every month of the year at Barbados between August 1974 and June 1976. It was immediately located in a plankton sample taken off Bernuda during this study. Given the occurrence of $T$. thiebantii in all tropical oceans, Borstad and Brinckmann-Voss hypothesized that the species may have a wide distribution.

Hydroids of this species were collected by Geiselman (1977) during a cruise "from Spain to Bermuda," but the closest of her records to Bermuda was in mid-North Atlantic near $30^{\circ} \mathrm{N}, 44^{\circ} \mathrm{W}$.

\section{KNOWN RANGE}

Bermuda: first record.

Elsewhere: western Atlantic (Borstad and BrinckmannVoss, 1979); eastern Atlantic (Geiselman, 1977).

\section{Family Eudendriidae L. Agassiz, 1862}

Eudendroidae L. Agassiz, 1862:342 [emended to Eudendriidae by Hincks, 1868].

Myrionemidae Pictet, 1893:18.

\section{DIAGNOSIS}

Hydroid colonies usually erect with branched hydrocauli, arising from a creeping hydrorhiza; growth monopodial with terminal hydranths. Perisarc firm, reaching to groove at base of hydranth. Hydranth often large, urn-shaped to elongate; hypostome typically llared, flexible. Tentacles filiform, in a single whorl or in two or more close whorls.

Gonophores fixed sporosacs, originating on hydranth beneath tentacles, often arranged in a whorl, reproductive hydranth often reduced to a blastostyle. Male gonophore with one or more bulbous chambers, successive chambers in a linear series. Female gonophore initially with curved spadix, each spadix supporting a single egg.

\section{REMARKS}

Species of the family Eudendriidae L. Agassiz, 1862, are immediately distinguishable from other athecate hydroids by the shape of the hypostome, which is large. Hexible, and usually flaring distally. The classification of the Eudendriidae has been spared the dual nomenclature found in many other families of athecate hydroids because all known species reproduce sexually by fixed sporosacs. The sexes are usually on separate colonies, although Eudendrinm motzkossowskae Picard, 1951, is reportedly hermaphroditic (Picard, 1951).

The family comprises two genera. Eudendrium Ehrenberg, 1834, a well-known genus with a worldwide distribution, includes many nominal species. Myrionema Pictet. 1893, has been reported infrequently, is apparently restricted to shallow-water habitats in the tropics and subtropics, and includes only three nominal species. Both genera are found in Bermuda.

\section{Genus Eudendrium Ehrenberg, 1834}

Calamella Oken, 1815:55 [invalid name, published in work rejected for nomenclatural purposes by the ICZN, Opinion $417]$.

Eudendrium Ehrenberg, 1834:72. 
Conymbogonium Allman, 1861:171.

Edendrium Allman, 1872:295 [incorrect subsequent spelling].

Erudendium Thompson, 1899:583 |incorrect subsequent spelling].

\section{DIAGNOSIS}

Eudendriidae with calyx of hydranth moderately short, urn-shaped. Tentacles in one whorl, of varied number but usually fewer than 35 .

\section{TYPE SPECIES}

Tubularia ramosa Linnaeus, 1758, by subsequent designation by Allman (1872).

\section{REMARKS}

Cornelius (1976) noted that the widely used generic name Eudendrium Ehrenberg. 1834, was threatened by the infrequently used name Thoa Lamouroux, 1816. Two species had originally been included in Thoa by Lamouroux (1816), T. savignii Lamouroux, 1816, and Sertularia halecina Linnaeus, 1758. The former is a junior objective synonym of Tubularia ramea Pallas, 1766, a species now referred to Eudendrium. Sertularia halecina had commonly been referred to Halecium Oken, 1815, a generic name invalidated (Opinion 417) because it was originally published in a work that was not consistently binominal. As a solution to these nomenclatural problems, Lemche (1976) recommended that the ICZN (I) validate, under the plenary powers, the generic name Halecium Oken, 1815. as requested by Cornelius (1976), and (2) designate Sertularia halecina Linnaeus, 1758, as the type species of Thoa. This proposal was adopted (Opinion 1220), with Thoa becoming a junior objective synonym of the valid name Halecium.

Another threat to Eudendrium has been removed elsewhere in this report (p. 64) by designating Tubularia muscoides Linnaeus, 1761, as the type species of Fistulana O. F. Müller, 1776a. In so doing. Fistulana becomes a junior subjective synonym of Coryne Gaertner, 1774.

The genus Eudendrium comprises a common and distinctive group of hydroids. However, there are many nominal species in the genus that are by no means easily distinguished, and a large number of these are of questionable validity. Fraser (1944) noted that descriptions of many of the 22 nominal species of Eudendrium reported from the western North Atlantic are meagre and based on incomplete specimens. The taxonomy of the genus has been further complicated because species have often been described on the basis of taxonomically unreliable characters. In addition, there has been little evidence, particularly in the older literature, of an appreciation of the considerable range of colony form that can occur within a species.
Watson (1985) emphasized the value of the cnidome in identification of species of Eudendrium from Australia. Interspecific differences that were noted by Watson in the complement of nematocyst categories present, and in the length-width ratios of nematocyst capsules of a given category, could be used as a taxonomic character.

\section{Eudendrium bermudense, sp. nov.}

Figs. 27-29

\section{MATERIAL, EXAMINED}

Holotype: Sailor's Choice Cave. Hamilton Parish, on ledge at entrance, $-1.5 \mathrm{~m}, 30$ June 1983 , one colony, $2.0 \mathrm{~cm}$ high, with female gonophores, ROMIZ B333. Paratypes: Sailor's Choice Cave, Hamilton Parish, on ledges and survey line at entrance, -1 to $-2 \mathrm{~m}, 30$ June 1983. two colonies, 3.2 and $3.8 \mathrm{~cm}$ high, with male gonophores; one colony, $2.0 \mathrm{~cm}$ high, with female gonophores; ROMIZ B334. Sailor's Choice Cave, Hamilton Parish, on ledges at entrance, $-1 \mathrm{~m}, 27$ June 1983, three colonies, $2.0-3.5 \mathrm{~cm}$ high, with female gonophores, RomIz B335. Castle Harbour, under causeway near halfway point, on rocks and shells, $-1 \mathrm{~m}, 1$ October 1986, five colonies, up to $6.6 \mathrm{~cm}$ high, with female gonophores: four colonies, up to $4.6 \mathrm{~cm}$ high, with male gonophores; one sterile colony, $3.5 \mathrm{~cm}$ high; ROMIZ B360.

\section{DESCRIPTION}

Colonies slender, straggly, up to $3.8 \mathrm{~cm}$ high, arising from a creeping hydrorhiza. Hydrocaulus upright, monosiphonic or slightly polysiphonic basally. more or less alternately branched in one plane, branches similarly rebranched or with alternate pedicels. Perisarc of moderate thickness, horn-coloured to dark brown basally, beconing progressively thinner and more colourless towards extremities, terminating at groove around base of hydranth, annulated at bases of hydrocaulus, branches, and pedicels. with occasional irregularly placed annulations elsewhere
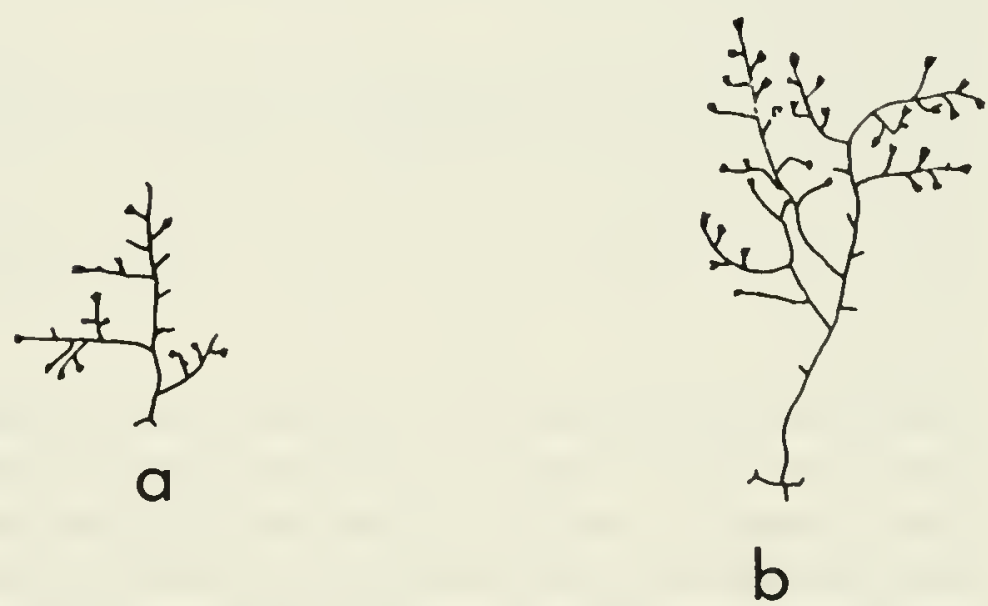

FIG. 27. Eudendrium bermudersese, sp. nov., colony form. Natural size. a, Holotype, Ronil, B333. b. Paralype, RoNIl\% B334. 

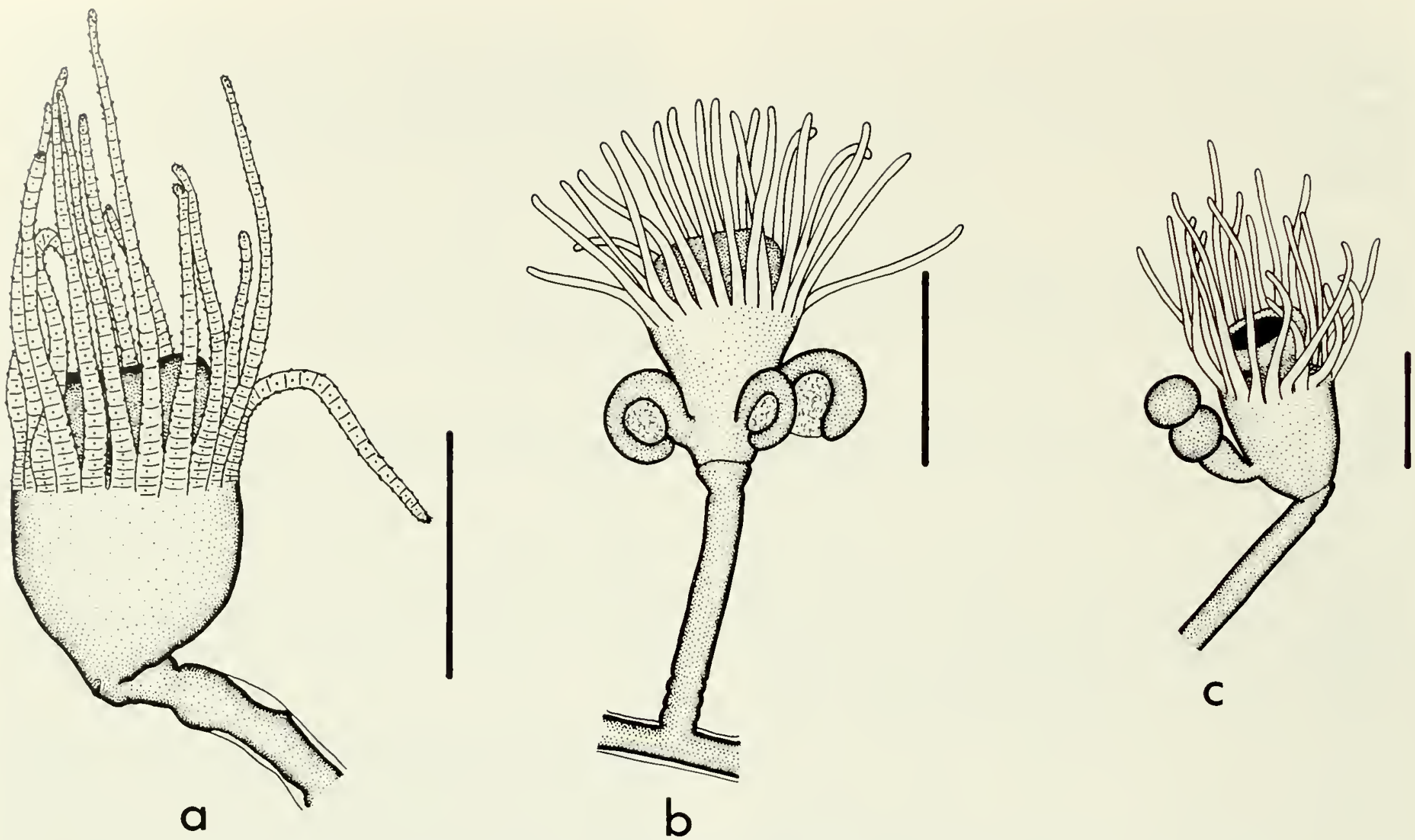

FIG. 28. Eudendrium bermudense, sp. nov., hydranths and gonophores. Scales equal $0.5 \mathrm{~mm} . a$, Hydranth, holotype colony, ROMIz B333. b, Hydranth with female gonophores, holotype colony, ROMIz B333. $c$, Hydranth with male gonophores, paratype colony, ROM1z B334.

but mostly smooth. Hydranths urn-shaped, 447-638 $\mu \mathrm{m}$ long from proximal end to base of hypostome when fully developed, 298-532 $\mu \mathrm{m}$ wide, with a shallow but distinct perisarc groove basally; hypostome large, knob-shaped to flared. Tentacles 21 to 26 in number, solid, filiform, in one whorl.

Gonophores fixed sporosacs, originating distal to perisarc groove on hydranth. Female gonophores borne in a whorl on entire hydranths, spadix unbranched, curving over egg. Male gonophores with one or two chambers, borne on entire hydranths.

Nematocysts-

Hydroids: macrobasic euryteles (on hypostome, hydranth base, coenosarc) 29.4-34.5 $\mu \mathrm{m} \times 12.3-14.0 \mu \mathrm{m}$; heterotrichous microbasic euryteles (on tentacles, hypostome, hydranth, coenosarc) $8.0-8.4 \mu \mathrm{m} \times 3.4-3.7 \mu \mathrm{m}$.

\section{REMARKS}

Eudendrium bermudense, sp. nov., differs from its Bermudian congeners in having macrobasic euryteles in addition to microbasic euryteles. In possessing nematocysts of the former category, $E$. bermudense resembles $E$. infundibuliforme Kirkpatrick, 1890, E. glomeratum Picard, 1951, and E. motzkossowskae Picard, 1951, as well as
Myrionema amboinense Pictet, 1893. Unlike E. infundibuliforme, hydranth pedicels of $E$. bermudense are not expanded distally. In contrast with $E$. glomeratum, macrobasic euryteles of $E$. bermudense are scattered rather than being aggregated in dome-shaped batteries on the hydranth column. There is no evidence that the gonophores of $E$. bermudense are hermaphroditic, as has been reported in E. motzkossowskae (e.g., see Motz-Kossowska, 1905; Picard, 1951; Millard, 1975; Boero, 1981). Eudendrium bermudense is immediately distinguishable from $M$. amboinense in having more regularly branched colonies, smaller hydranths, and fewer tentacles, and in lacking algal symbionts. The hydroids resemble descriptions of $E$. angustum Warren, 1908, which has large nematocysts of uncertain identity (Millard, 1975), but the hypostome of the latter is reportedly "blocked" by a solid plug of endodermal cells (Warren, 1908; Millard, 1975). No such plug was apparent in specimens of E. bermudense. Finally, large nematocysts, believed by Watson (1985) to be macrobasic euryteles, occur in E. aylingae Watson, 1985, and $E$. currumbense Watson, 1985. However, E. aylingae is apparently a much smaller species than $E$. bermudense, and the macrobasic euryteles(?) of E. currumbense are considerably smaller than those of $E$. bermudense. 

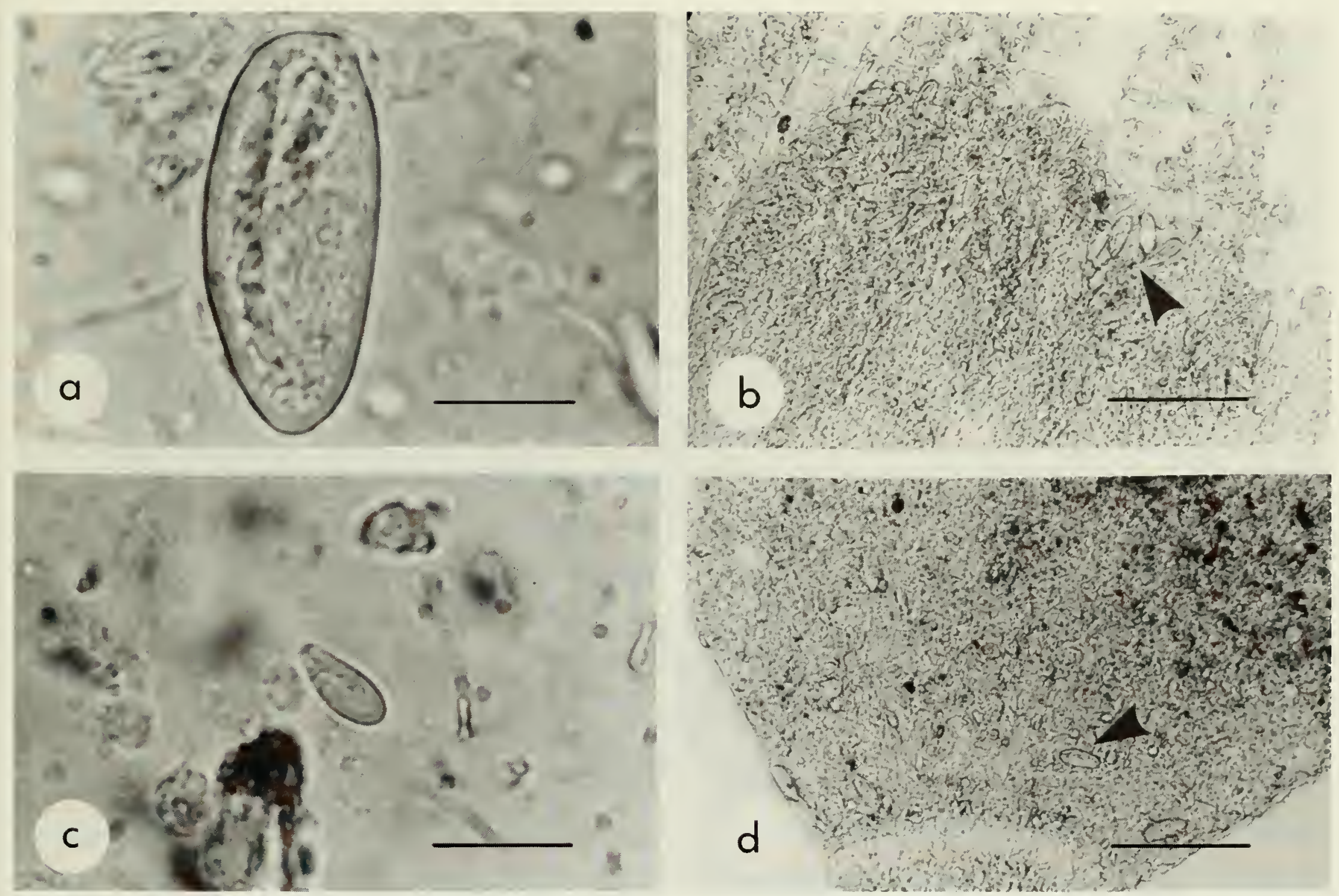

FlG. 29. Eudendrium bermudense, sp. nov., nematocysts of hydranth, RomIz B333. Scales for $a$ and $c$ equal $10 \mu \mathrm{m}$; scales for $b$ and $d$ equal $100 \mu \mathrm{m}$. $a$, Macrobasic eurytele. $b$, Hypostome with macrobasic euryteles. $c$, Heterotrichous microbasic eurytele. $d$, Hydranth base with macrobasic euryteles.

\section{ETYMOLOGY}

The specific name refers to the occurrence of the species in Bermuda.

\section{KNOWN RANGE}

Known only from the type locality.

\section{Eudendrium capillare Alder, 1856a}

Figs. $30-32$

Eudendrium capillare Alder, 1856a:355; pl. 12, figs. 9-12 Corymbogonium capillare-Allman, 1861:171.

Dicoryne capillare -Alder, 1862:230.

Eudendrium tenue A. Agassiz, 1865:160; fig. 250.

Eudendrium capillare var. mediterranea Neppi, 1917:30.

Eudendrium parvum Warren, 1908:272; fig. 1; pl. 45, figs. $\mathrm{I}-4$.

not Eudendrium ?capillare-Millard, 1966:454 | = Eudendrium ramosum (Linnacus, 1758)].

\section{TYPE LOCALITY}

Embleton Bay, Northumberland, Great Britain.

\section{MATERIAL EXAMINED}

Castle Island, Castle Harbour, on underside of flat rocks, $-2 \mathrm{~m}, 30$ July 1982, one colony, $13 \mathrm{~mm}$ high, with male gonophores; two colonies, 6-13 $\mathrm{mm}$ high, without gonophores; RomIZ BI42. Hungry Bay, on underside of flat rocks, $-1.5 \mathrm{~m}, 6$ September 1977. two colonies, I1$17 \mathrm{~mm}$ high, with female gonophores, ROMIz B 61.

\section{DESCRIPTION}

Colonies small, slender, straggly, up to $17 \mathrm{~mm}$ high, arising from a creeping hydrorhiza. Hydrocaulus upright. monosiphonic, 100-125 $\mu \mathrm{m}$ wide, irregularly to more or less alternately branched: branches in turn alternately to irregularly branched; pedicels often long and bent. Perisarc relatively thick and golden-coloured at base of colony. becoming progressively thinner and colourless towards extremities, terminating at groove around base of hydranth. 

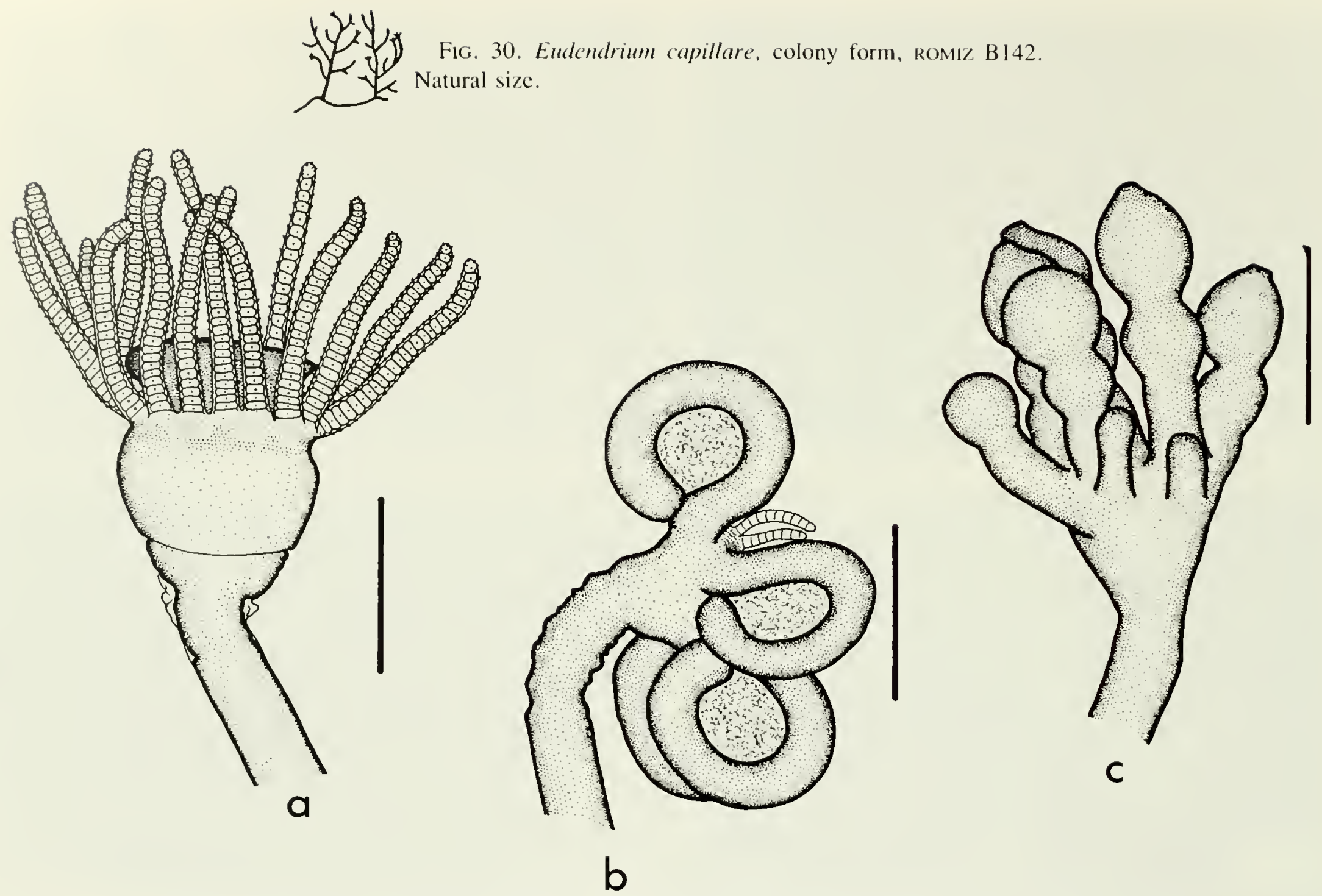

F1G. 31. Eudendrium capillare, hydranths and gonophores. Scales equal $0.25 \mathrm{~mm}$. $a$, Hydranth, ROMLZ B 142. $b$, Reduced hydranth with female gonophores, ROMIz B161. $c$, Reduced hydranth with male gonophores, ROMIZ B142.

annulated at bases of hydrocaulus, branches, and pedicels, and with irregularly placed annulations frequent elsewhere. Hydranths urn-shaped, 295-385 $\mu \mathrm{m}$ long from proximal end to base of hypostome, $250-340 \mu \mathrm{m}$ wide, with a shallow but distinct perisarc groove basally. Hypostome large, flared. Tentacles 15 to 20 in number, solid, filiform, in one whorl.

Gonophores fixed sporosacs, originating distal to perisarc groove on hydranth. Female gonophores borne in a whorl on hydranths with partially atrophied tentacles; spadix unbranched, curving over egg. Male gonophores with up to three chambers each, borne on atrophied hydranths; terminal chamber with an apical tubercle.

Nematocysts-

Hydroids: heterotrichous microbasic euryteles (on tentacles, hydranth, and elsewhere) 7.1-8.0 $\mu \mathrm{m} \times 3.0$ $3.2 \mu \mathrm{m}$

\section{REMARKS}

Records suggest that Eudendrium capillare Alder, 1856a, is widely distributed (Vervoort, 1959), but Millard (1975) cautioned that most records provide insufficient information to verify identification. Although the species has been frequently recorded from warm waters (e.g. Fraser, 1912, 1948; Mammen, 1963; Millard and Bouillon. 1974; Cooke. 1975; Millard, 1975), hydroids from Bermuda were nevertheless referred to $E$. capillare with some reservation given the northerly type locality of this species. Unfortunately, type material of E. capillare could not be located (Cornelius and Garfath, 1980), but specimens from Bermuda corresponded with Alder's (1856a) figures and brief description of the species. Bermuda specimens are also identical in all major respects, including the complement and arrangement of nematocysts, with more detailed accounts of the species given by Millard and Bouillon (1974) from East Africa and by Millard (1975) from South Africa.

A small hydroid somewhat resembling Eudendrium capillare in colony form was described and named $E$. tenellum by Allman (1877) from material collected at a depth of 471 fathoms $(861 \mathrm{~m})$ off Florida. Hydranths and gonophores, both of which are now generally regarded as essential for diagnosis of any species of the genus Eudendrium 


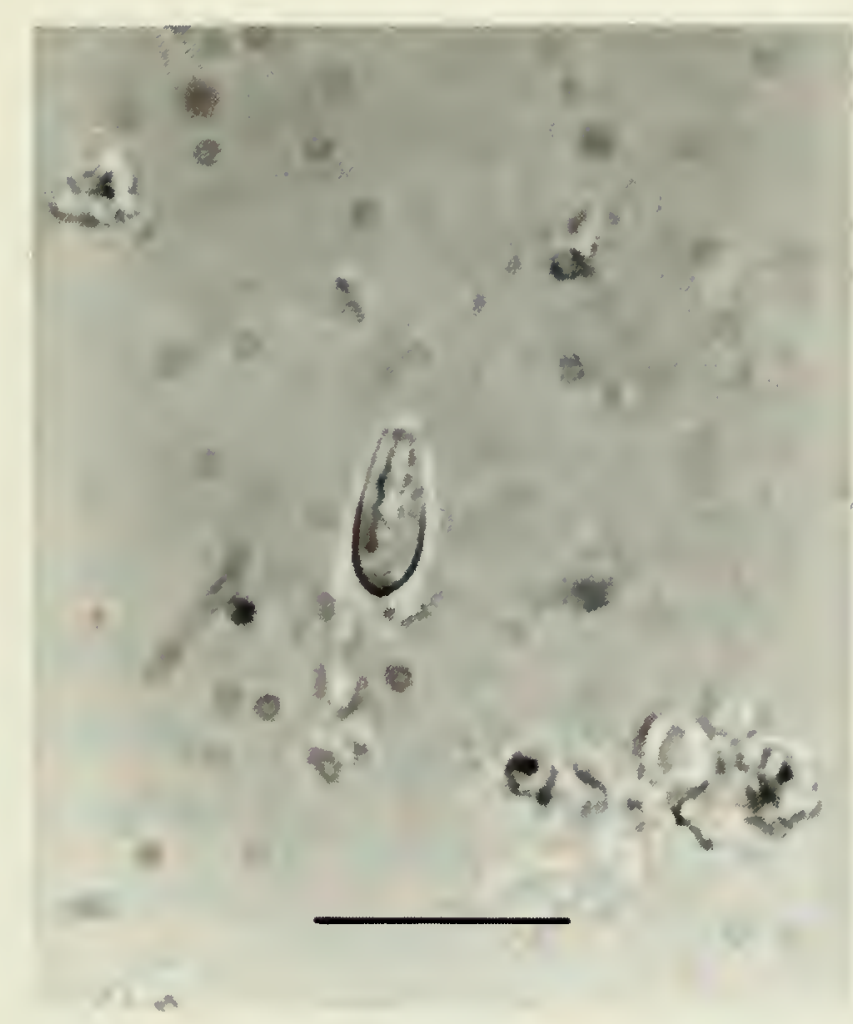

FlG. 32. Eudendrium capillare, heterotrichous microbasic eurytele from hydranth, Romiz B161. Scale equals $10 \mu \mathrm{m}$.

Ehrenberg, 1834, were lacking in Allman's material. In fact, Allman was not certain that his specimen belonged to Eudendrium. He stated (1877:8): "lts reference to this genus is probably correct, but as neither hydranths nor gonophores were present in the specimen, it may possibly have its true place in some other." Nonetheless, many authors have identified small hydroids of this genus as $E$. tenellum, and the species has been reported from Atlantic, Pacific, Arctic, and Indian oceans (e.g., Stechow, 1923a; Fraser, 1937, 1944, 1948; Kramp, 1943; Yamada, 1959; Calder, 1972; Hirohito, 1977). It is unfortunate that the name E. tenellum, based on unrecognizable material and regarded here as a nomen dubium, should subsequently have been applied to what is seemingly a recognizable species. It is not possible to ascertain whether any of the later records of E. tenellum are actually conspecific with the hydroid upon which the name is based. These records are founded on one or more species of Eudendrium, apparently differing from $E$. capillare in having gonophores on entire rather than on atrophied hydranths. Naumov (1960) regarded E. tenellum auct. as a synonym of E. capillare, and Christiansen (1972) concurred with this view. Calder (1972), Hirohito (1977), and others have regarded the two as distinct based on differences in colony form and degree of reduction of hydranths bearing gonophores. Naumov (1960) also regarded E. hyalimum Bonnevie, 1899b, as conspecific with $E$. capillare. Bonnevie's (1899b) material was sterile and her description was so general that the identity of her hydroid is uncertain, although it could be identical with the E. tenellum of some authors. 1 have, therefore, not regarded it as conspecific with E. capillare.

Hincks (1868) regarded Eudendrium tenue A. Agassiz, 1865 , as possibly conspecific with $E$. capillare. Vervoort (1946b) thought likewise, and I concur. Eudendrium parvium Warren, 1908, also seems conspecific with E. capillare, for reasons given by Millard (1966).

\section{KNOWN RANGE}

Bermuda: first record.

Elsewhere: western Atlantic (Fraser, 1944): eastern Atlantic (Hincks, 1868); Indian Ocean (Millard, 1975); western Pacific (Yamada, 1959); eastern Pacific (Fraser, 1937).

\section{Eudendrium carneum Clarke, 1882}

Figs. 33-35

Eudendrium ramosum-McCrady, 1859a:166. -A. Agassiz, 1865:160. -Congdon, 1906:27; figs. 1-4; 1907:464. -Fraser, 1912:349; figs. 8A-C; 1943:87. Bennitt, 1922:245 [not Eudendrium ramosum (Linnaeus, 1758)].

Eudendrium carneum Clarke, 1882:137; pl. 7, figs. 10-17. Eudendrium cumninghami Kirkpatrick, 1910:127; pl. 7 . figs. 1-3.

\section{TYPE LOCALITY}

Fort Wool, Hampton Roads, Virginia, United States.

\section{MATERIAL EXAMINED}

Hamilton Harbour, on mooring chain, $-2.5 \mathrm{~m}, 12$ November 1976, two colonies, $6.4 \mathrm{~cm}$ high, with female gonophores, coll. J. Markham, L. Coen, G. Rupp, ROMIZ B134. Flatts Inlet, on concrete pier, - 2 m, 24 May 1979. five sterile colonies, up to $6 \mathrm{~cm}$ high; seven colonies, up to $6 \mathrm{~cm}$ high, with male gonophores; five colonies, up to $10 \mathrm{~cm}$ high, with female gonophores; RomIz B 135. Castle Grotto, Castle Harbour, on cave wall 25-50 m from entrance, $-1 \mathrm{~m}, 20$ July 1982 , one sterile colony. $5.8 \mathrm{~cm}$ high, ROMIZ B148. Flatts Inlet, on rocks, $-0.5 \mathrm{~m}, 27$ February 1982, one colony, $9.3 \mathrm{~cm}$ high, with male gonophores, Rоміz B166. Ferry Reach, St George's Island, on rope, -0.5 to $-2 \mathrm{~m}, 2$ September 1977 , one male colony, $3.6 \mathrm{~cm}$ high; one sterile colony, $10.5 \mathrm{~cm}$ high: ROMIz B176. Somerset Bridge, on concrete wall, $-2 \mathrm{~m}, 15 \mathrm{Sep}-$ tember 1977, one male colony, $10 \mathrm{~cm}$ high, romiz B 178 .

\section{DESCRIPTION}

Colony extensively branched and bushy, up to $10.5 \mathrm{~cm}$ high, arising from a crecping mass of hydrorhizal stolons. Hydrocaulus upright, polysiphonic, more or less alternately branched; primary branches also polysiphonic and 
alternately or somewhat irregularly branched; secondary branches often polysiphonic basally and branched in like manner. Perisarc thick and brownish-coloured in older parts of colony, thinner and paler towards extremities, annulated or wrinkled at bases of branches and hydranth pedicels, with occasional annulations elsewhere but mostly smooth, terminating almost imperceptibly at groove around hydranth base. Hydranths urn-shaped, about $0.8 \mathrm{~mm}$ long from proximal end to base of hypostome, $0.65 \mathrm{~mm}$ wide, with a shallow perisarc groove and a ring of anisorhiza nematocysts basally; hypostome very large, flared to knobshaped. Tentacles about 27 to 32 in number, solid. filiform, in one whorl.

Gonophores fixed sporosacs, developing on hydranth distal to perisarc groove. Female gonophores on reduced hydranths with partially atrophied tentacles; spadix bifid, curving over egg. During development, spadices shed, embryos borne in perisarc-covered capsules arranged irregularly along pedicel, perisarc of gonophore pedicel extensively wrinkled, terminal hydranth eventually lost. Male gonophores with up to five chambers each, borne on atrophied hydranths: distal end of gonophore with scattered anisorhiza nematocysts.

Nematocysts-

Hydroids: heterotrichous anisorhizas (on hydranth base, hypostome, and tips of male gonophores) 20.3-23.0 $\mu \mathrm{m}$ $\times 9.4-11.3 \mu \mathrm{m}$; heterotrichous microbasic euryteles (on tentacles, hydranth, and elsewhere) $8.3-9.4 \mu \mathrm{m} \times 3.6-$ $4.0 \mu \mathrm{m}$.

\section{REMARKS}

Allman (1877) described and named eight new nominal species of Eudendrium Ehrenberg. 1834, from the southeastern United States, where E. carneum Clarke, 1882, is now known to be frequent (Fraser, 1944: Calder and Hester, 1978). One of these, E. tenellum, was discussed earlier. Of the remaining seven, all differ from $E$. carnetum in one or more respects. The hydrocaulus was described as monosiphonic, rather than polysiphonic, in E. attenitatum, E. laxum, and E. cochleatum. The number of tentacles borne by the hydranth was reported to be only about 20 , instead of 25 or more, in E. eximium, E. exiguum, and E. fruticosum. Annulations at the bases of branches and pedicels, well marked in $E$. carneum, were faint or even absent in E. eximium, E. fruticosum, and E. gracile. Reproductive hydranths, reduced or aborted in $E$. carneum, were little if at all aborted in E. eximium, E. fruticosum, and E. laxum. Unfortunately, gonophores were lacking in Allman's material of E. exiguum and E. gracile, and both gonophores and hydranths were lacking in his specimens of $E$. attenuatum. Characters such as tentacle number, degree of atrophy of reproductive hydranths, extent of perisarc annulation, and number of tubes comprising the hydrocaulus are known to vary intraspecifically in

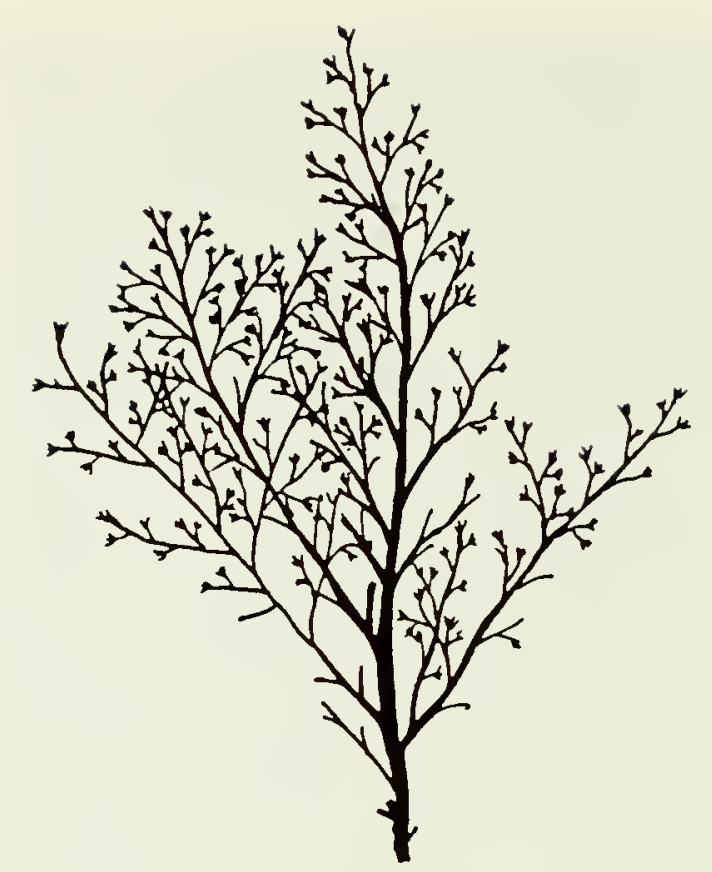

FIG. 33. Eudendrium carneum, colony form, ROMIz BI35. Natural size.

Eudendrinm, but all Allman's species appear to have been different from E. carneum. So does E. distichum, described by Clarke (1879) from material obtained southwest of Key West, Florida, in 339 fathoms $(620 \mathrm{~m})$ of water. Although $E$. distichlim appears to have resembled $E$. carneum in colony size and general shape, it seems to have had only 16 to 20 tentacles on the hydranth. Some of Allman's (1877) species were evidently distinguished on the basis of relatively minor differences, and their status needs to be re-evaluated.

In Bermuda, Eudendrium carneum was abundant during warm months in areas swept by strong tidal currents, such as Flatts Inlet and the Somerset Bridge area. Specimens with active hydranths and gonophores were also collected in Flatts Inlet at $18^{\circ} \mathrm{C}$ during the winter of 1982 (ROMIZ B 166).

Eudendrium carneum has been reported previously from Bermuda as E. ramosum (Linnaeus, 1758) by Congdon $(1906,1907)$ and Bennitt $(1922)$. Records of E. ramosum from the southeastern United States by McCrady (1859a), A. Agassiz (1865), and Fraser (1912, 1943b) were also likely based on material of $E$. carneum. Ultrastructural studies on spermatozoa of $E$. carnetum were conducted in Bermuda by Summers (1972a), again on hydroids misidentified as E. ramosum.

\section{KNOWN RANGE}

Bermuda: no specific locality given (Congdon, 1906, 1907); Hamilton Harbour (Bennitt, 1922); Flatts Inlet (Summers, 1972a); shallow inshore waters (Calder, 1986).

Elsewhere: western Atlantic (Fraser, 1944); eastern Atlantic (Kirkpatrick, 1910); Indian Ocean (Millard, 1975); eastern Pacific (Fraser, 1948). 

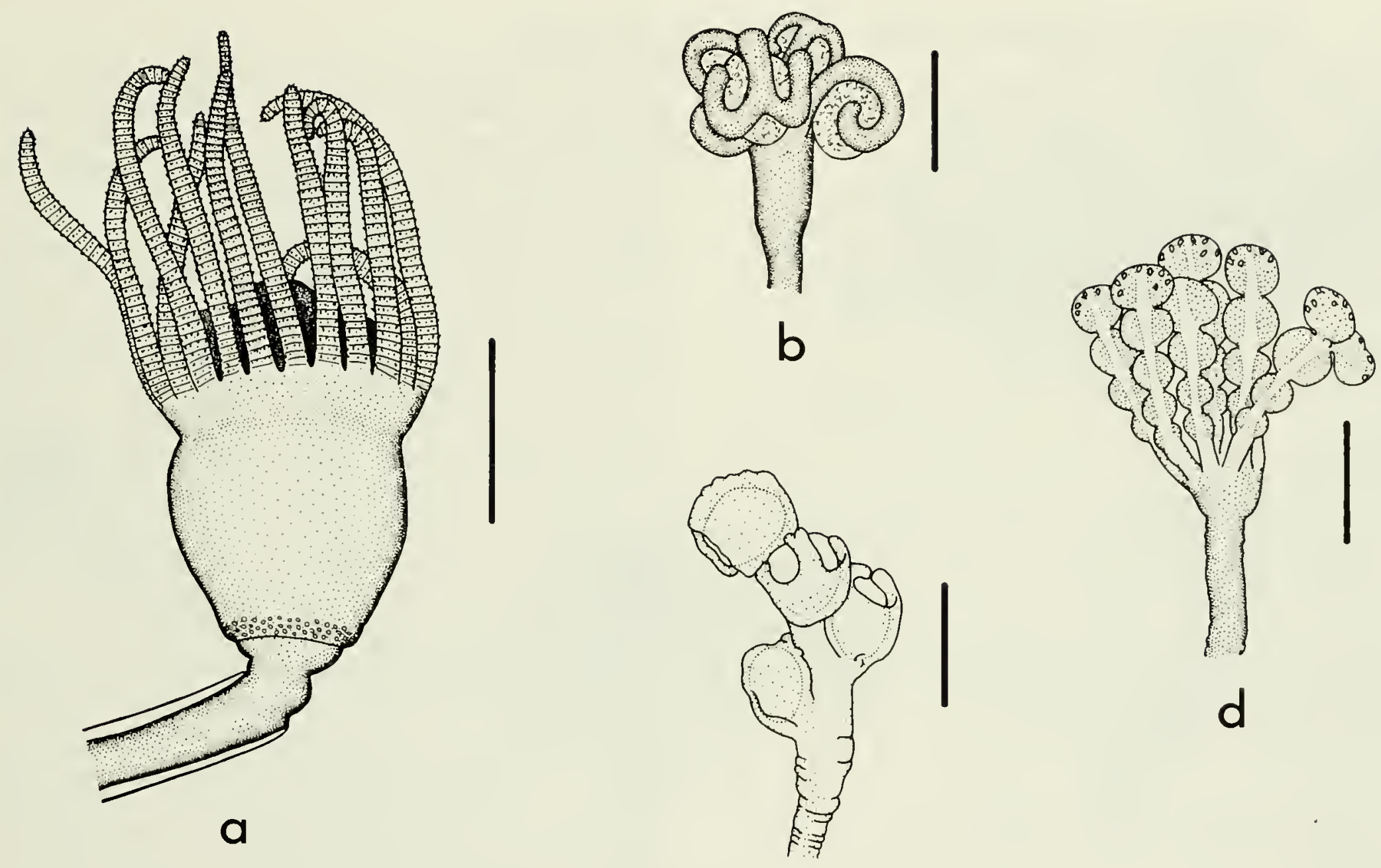

\section{C}

FIG. 34. Eudendrium carneum, hydranths and gonophores, ROMiz B135. Scales equal $0.5 \mathrm{~mm}$. a, Hydranth. $b$, Reduced hydranth with female gonophores. $c$, Pedicel with capsules containing embryos. $d$, Reduced hydranth with male gonophores.
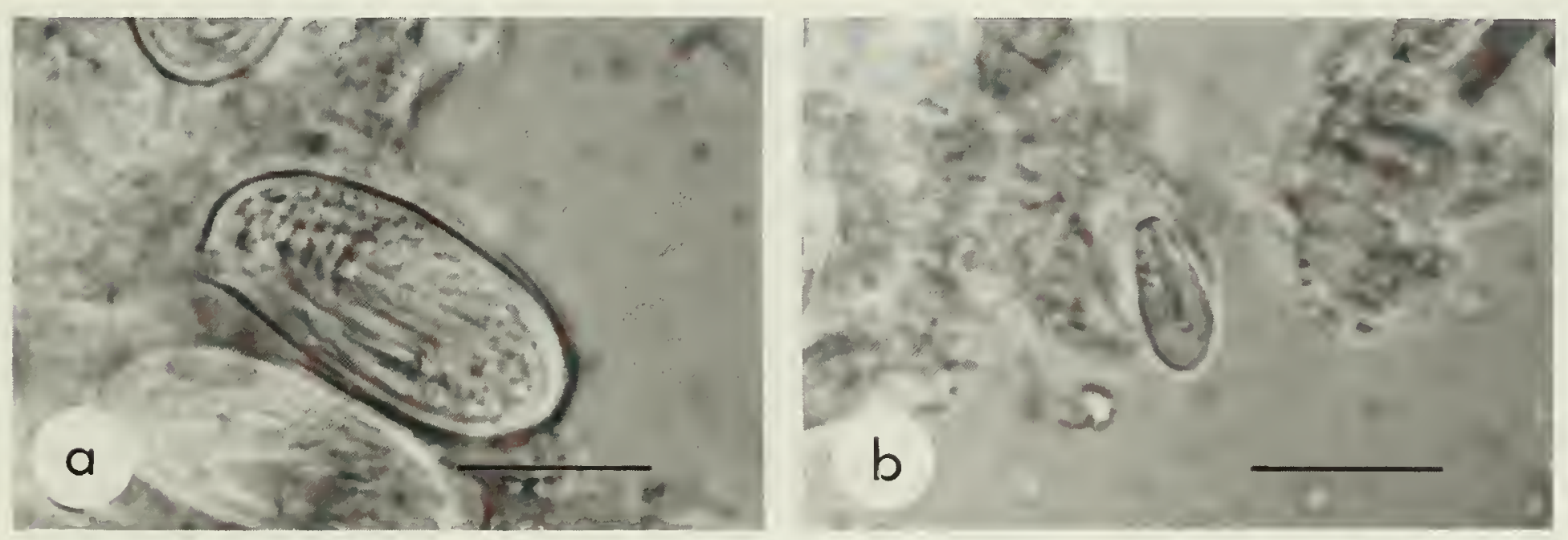

FIG. 35. Eudendrium carneum, nematocysts of hydranth, ROMIz B135. Scales equal $10 \mu \mathrm{m}$. $a$, Heterotrichous anisorhiza. $b$, Heterotrichous microbasic eurytele. 
Genus Myrionema Pictet, 1893

Mrrionema Pictet, 1893:18.

\section{DIAGNOSIS}

Eudendriidae with calyx of hydranth elongate, often columnar below tentacles. Tentacles in two or more close whorls, number varied but commonly 40 or more.

\section{TYPE SPECIES}

Myrionema amboinense Pictet, 1893, by monotypy.

\section{REMARKS}

This genus was instituted by Pictet (1893) for a new species, Myrionema amboinense, from the western Pacific. The greater number of tentacles, which occur in several close whorls, and the elongate calyx of the hydranth distinguish hydroids of this genus from the more familiar Eudendrium Ehrenberg, 1834. Hydroids of this genus contain symbiotic zooxanthellae in their tissues and are apparently restricted to shallow water.

\section{Myrionema amboinense Pictet, 1893}

Figs. 36, 37

Myrionema amboinensis Pictet, 1893:19, 62; pl. 1, figs. 12,13; pl. 3 , figs. 55,56 .

Eudendrium hargitti Congdon, 1906:27; figs. 5-11.

"Eudendrium" hargettii-Wallace, 1909:137 lincorrect subsequent spelling].

Eudendrinm griffini Light, 1913:333; figs. 1-5; pls. 1, 2. Eudendrium amboinensis-Leloup, 1932:143; fig. 15; pl. 16, fig. 1.

Myrionema amboinense-Briggs and Gardner, 1931:184; pl. 1, figs. 1-3.

Myrionema hargitti-Spracklin, 1982:240; fig. 114b.

Myrionema griffini-Watson, 1985:180.

\section{TYPE LOCALITY}

Baton-Mera, Ambon, Moluccas, Indonesia.

\section{MATERIAL EXAMINED}

Tucker's Town Bay, Castle Harbour, on pontoon anchor chain, $-1 \mathrm{~m}, 23$ July 1982, one colony, $3.5 \mathrm{~cm}$ high, with male gonophores, Romiz B 141. Tucker's Town Bay, Castle Harbour, on pontoon anchor chain, $-0.5 \mathrm{~m}, 5$ March 1982, three colonies, 3.5-5.6 cm high, without gonophores, ROMIZ B171. Walsingham Pond, on rocky cliff, $-2 \mathrm{~m}, 5$ September 1977, one colony, $3.4 \mathrm{~cm}$ high, without gonophores, ROMIz B179. Whalebone Bay, on rocks in Thalassia bed, $-0.5 \mathrm{~m}, 24$ June 1983, seven colonies, $1.3-4.0 \mathrm{~cm}$ high, with female gonophores, ROMIZ B329.

\section{DESCRIPTION}

Colonies straggly, growing in clumps up to $5.6 \mathrm{~cm}$ high; hydrorhiza creeping. Hydrocaulus monosiphonic, 0.16$0.25 \mathrm{~mm}$ in diameter, sparingly and irregularly branched; primary branches unbranched or irregularly branched, often directed upwards and resembling hydrocaulus in appearance and size. Perisarc thin, flexible, straw-coloured to virtually colourless, usually annulated or faintly wrinkled at bases of branches, mostly smooth elsewhere, terminating at groove around hydranth base. Hydranth reaching about $1.7 \mathrm{~mm}$ long from proximal end to base of hypostome, urn-shaped to club-shaped with a long, cylindrical calyx, widest at tentacle-bearing region, with a shallow perisarc groove and a ring of macrobasic eurytele nematocysts basally. Hypostome large, flared to knobbed. Tentacles up to $2 \mathrm{~mm}$ long, about 35 to 60 in number, solid, filiform, in two or more close whorls. Hydranth and tentacles bearing large numbers of zooxanthellae.

Gonophores fixed sporosacs, originating on hydranth proximal to tentacles. Male gonophores with one to four chambers, borne on entire hydranths. Female gonophores borne in a whorl of as many as eight or more on entire hydranths; spadix unbranched, curving over egg. During development, spadices shed, embryos borne in perisarccovered capsules arranged irregularly along pedicel.

Nematocysts-

Hydroids: macrobasic euryteles (on hydranth base, hypostome) $21.8-23.4 \mu \mathrm{m} \times 9.7-11.3 \mu \mathrm{m}$; heterotrichous microbasic euryteles (on tentacles, hydranth, and elsewhere) $8.5-9.4 \mu \mathrm{m} \times 3.5-3.8 \mu \mathrm{m}$.

\section{REMARKS}

Morphological differences between Myrionema hargitti (Congdon, 1906) from the tropical western Atlantic and M. amboinense Pictet, 1893, from the Indo-west Pacific appear to be negligible. Hydroids of both are shallowwater inhabitants harbouring large numbers of algal symbionts, and are brownish in colour when alive. Specimens of $M$. amboinense illustrated by Millard and Bouillon (1973) have longer calyces than hydroids referred to $M$. hargitti, but calyx length is highly variable in this genus. So too is tentacle number, although counts have usually been higher in $M$. amboinense. In $M$. hargitti, tentacle number has been reported as 35 to 45 (Congdon, 1907) and 35 to 60 (Bennitt, 1922). Tentacle number in M. amboinense, with which $M$. griffini (Light, 1913) is conspecific, has been reported as 80 to 120 (Pictet, 1893), 50 to 70 (Light, 1913), 40 to 50 (Hargitt, 1924), and 70 to 90 (Millard and Bouillon, 1973). Nematocyst types and sizes appear to be similar in the two. In proposing M. griffini, Light (1913) noted that the tentacles were heavily armed with nematocysts. Congdon $(1906,1907)$ reported that nematocysts were few in number on the tentacles of $M$. hargitti. An 


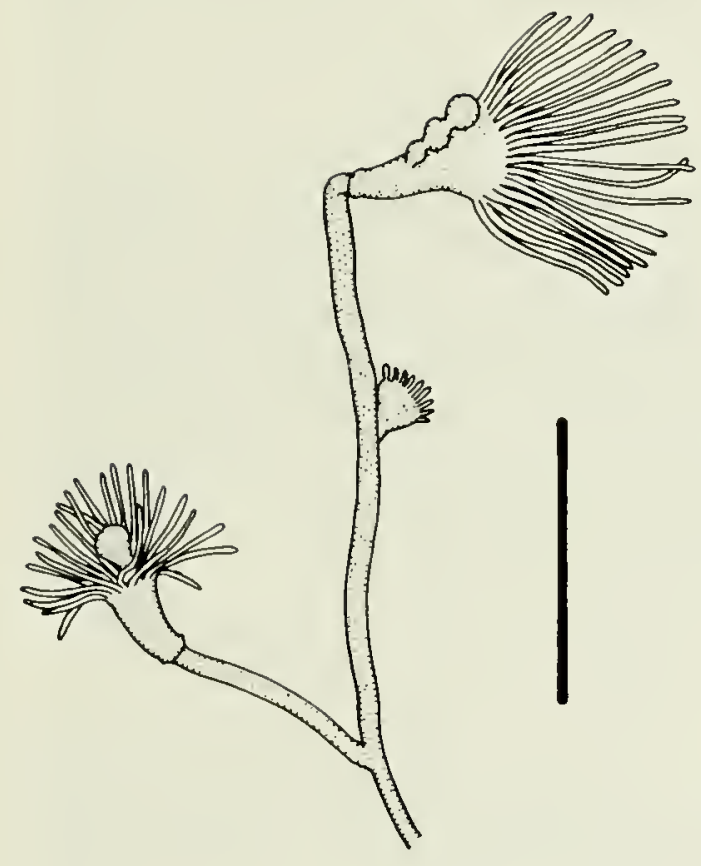

Q

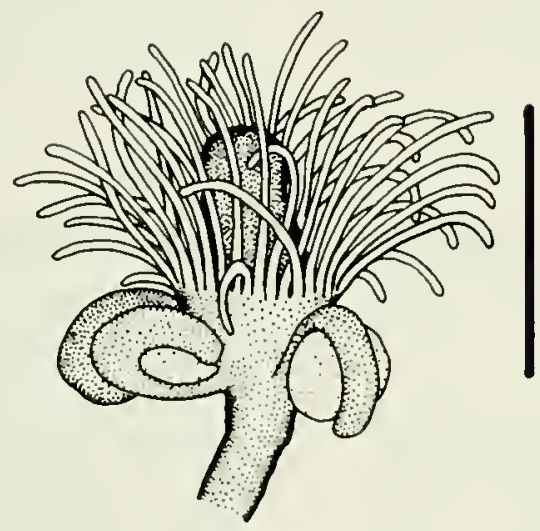

b

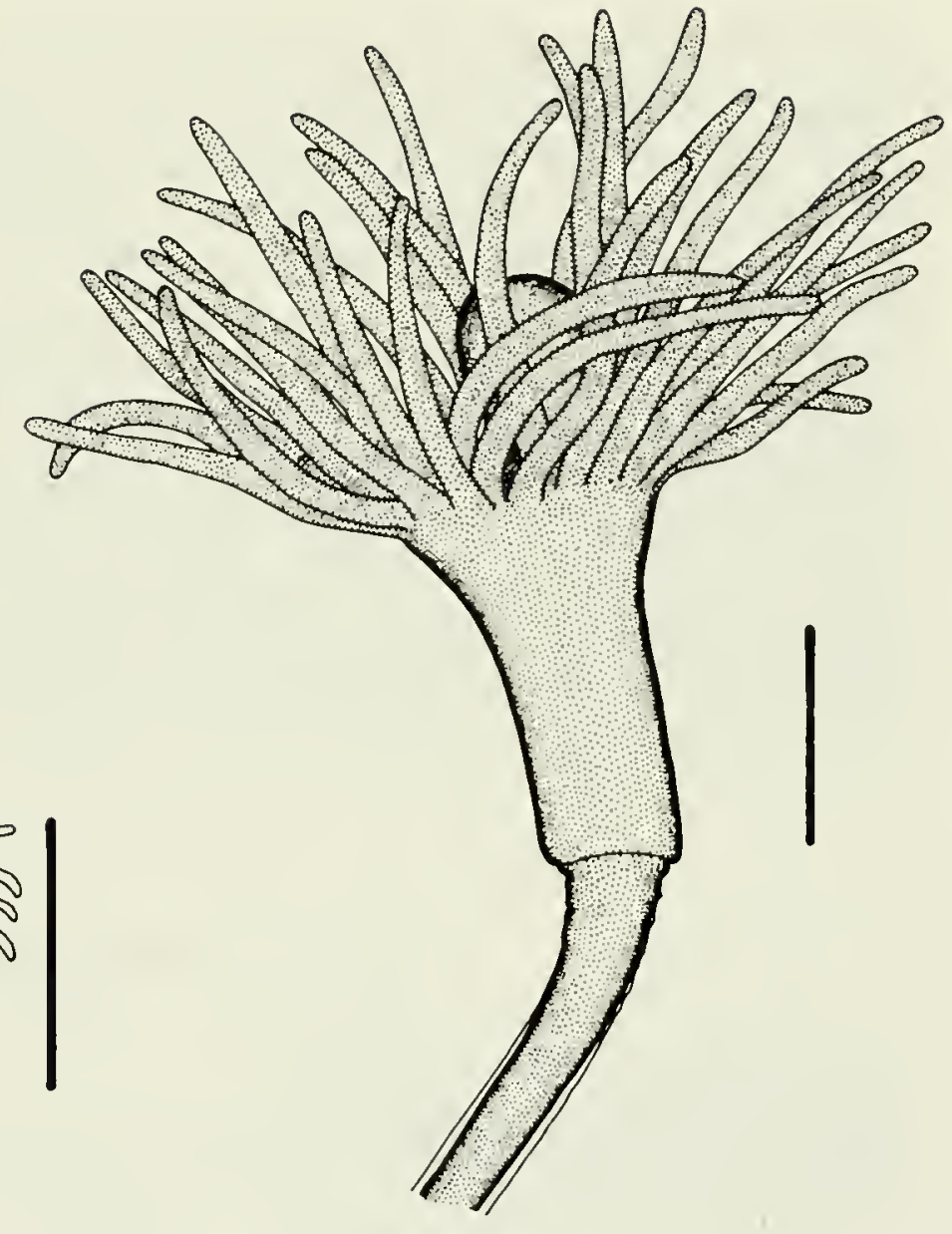

C

FIG. 36. Myrionema amboinense. Scale for $a$ equals $3 \mathrm{~mm}$; scale for $b$ equals $1 \mathrm{~mm}$; scale for $c$ equals $0.5 \mathrm{~mm}$. $a$, Hydrocaulus and hydranths, with a male gonophore, Romiz B 141. $b$, Hydranth, with female gonophores, ROMIZ B329. c, Hydranth, ROMIZ B141.
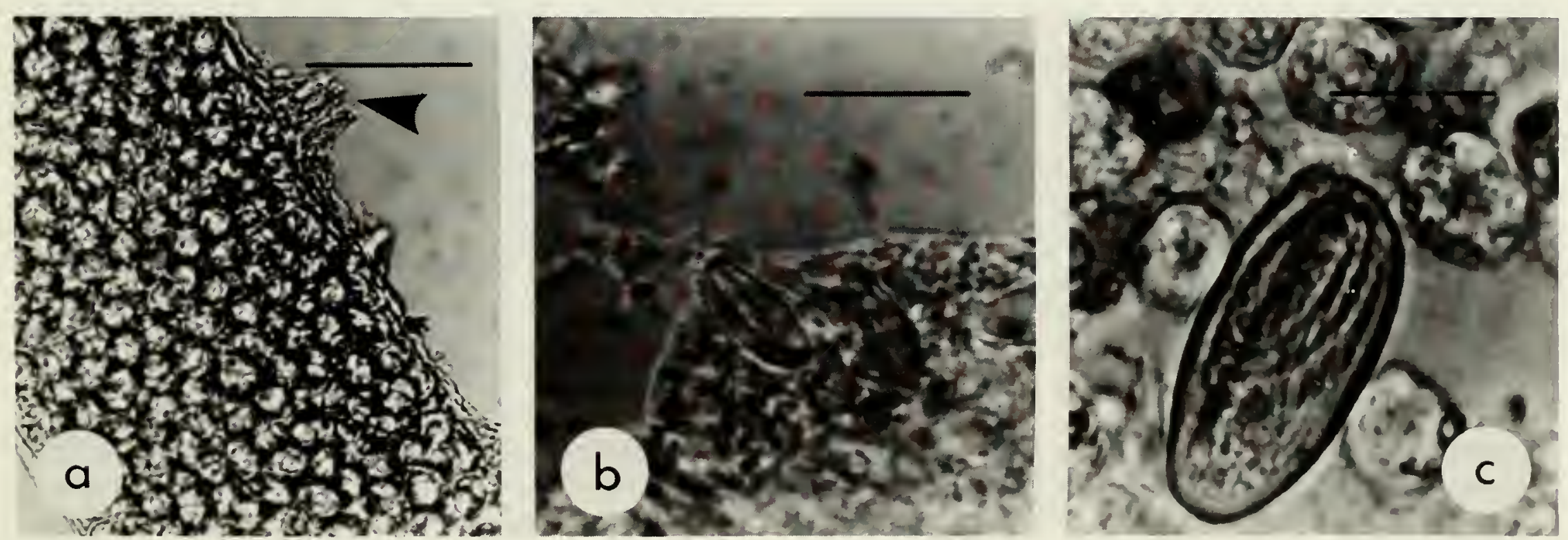

FIG. 37. Myrionema amboinense, Romiz B I7I. Scalc for $a$ equals $40 \mu \mathrm{m}$; scales for $b$ and c equal $10 \mu \mathrm{m}$ $a$, Part of a tentacle, with nematocyst battery (arrow) and algal symbionts. b. Heterotrichous microbasic eurytele. c, Macrobasic curytele. 
examination of the tentacles of Bermuda specimens of $M$. amboinense during this study revealed that nematocysts were present in moderate numbers (Fig. 37a). Although hydroids of the two nominal species are isolated geographically. I regard $M$. hargitti as conspecific with $M$. amboinense.

Myrionema amboinense was observed in Bermuda during this study only in shallow waters of relatively sheltered areas such as Tucker's Town Bay. It was also one of the few hydroid species collected in the quiet waters of Walsingham Pond. Bennitt (1922) reported this hydroid to be extremely abundant in Hungry Bay on the south shore of Bermuda, where it was first observed by Congdon (1906,
1907) and later seen by Smallwood (1910). Bennitt also located it just below low tide on buoys, timbers, ledges. and turtle grass throughout Hamilton Harbour and Great Sound.

\section{KNOWN RANGE}

Bermuda: no specific locality given (Congdon, 1906); inlet on south shore (Congdon, 1907); Hungry Bay (Smallwood. 1910); Hungry Bay. Hamilton Harbour, Great Sound (Bennitt, 1922); quiet inshore waters (Calder, 1986).

Elsewhere: western Atlantic (Fraser, 1944); eastern Atlantic (Picard, 1958); Indian Ocean (Millard and Bouillon. 1973); western Pacific (Pennycuik, 1959).

\section{Family Corymorphidae Allman, 1872}

Corymorphidae Allman, 1872:386.

Monocaulidae Allman, 1872:395.

Amalthaeidae Haeckel, 1879:37.

Steenstrupiini Cockerell, 1911:78.

Branchiocerianthidae Broch, 1916:21.

Paragotoeidae Ralph, 1959:176.

\section{DIAGNOSIS}

Hydroids solitary. Hydrocaulus upright, more or less cylindrical, invested with thin, flexible perisarc; usually with papillae and anchoring filaments basally. Hydranths terminal, flask-shaped, with oral and aboral bands of tentacles; oral tentacles capitate or filiform, in one or more close whorls; aboral tentacles filiform, in one whorl.

Gonophores fixed sporosacs or free medusae, generally borne on blastostyles arising from hydranth just distal to aboral tentacles. Medusa, when present, bell-shaped; exumbrella without tracks of nematocysts; manubrium short. with simple, circular mouth. Radial canals four. Marginal tentacles one to four. Ocelli absent. Gonads surrounding manubrium.

\section{REMARKS}

Allman (1872) established the family Corymorphidae to accommodate Corymorpha M. Sars, 1835, and several other nominal genera now considered identical with it. In the same publication, he founded the Monocaulidae to include Monocaulus Allman, 1864a. For much of the present century, the genera Monocaulus and Corymorpha, and the two families based on them, have been regarded as identical. The name Monocaulidae has fallen into disuse in favour of the name Corymorphidae, but to my knowledge criteria of the First Reviser Principle in nomenclature [Art. 24] have never been met in this case. The two are considered synonyms here, and the name Corymorphidae is assigned precedence over Monocaulidae in the interests of nomenclatural stability.

Rees (1957) recognized four subfamilies within the Corymorphidae. "Lower corymorphines," such as Euphysa Forbes, 1848, Hypolytus Murbach, 1899, and possibly Gymnogonos Bonnevie, 1898, were grouped in the Euphysinae Haeckel, 1879. "Higher corymorphines," including Corymorpha, were placed in the Corymorphinae. Boreohydra Westblad, 1937, considered an aberrant corymorphine by Rees, was retained in the Boreohydrinae Westblad, 1947. Branchiocerianthus Mark, 1898, viewed as a corymorphine with secondarily acquired bilateral symmetry, was placed in the Branchiocerianthinae Broch, 1916. Although there has been little outright criticism of this classification, Millard (1975) cautioned that subdivision of the family is still not settled. For example, Calder (1974) suggested that Boreohydra may be better referred to the family Myriothelidae Hincks, 1868 ( = Candelabridae Stechow, 1921a) rather than to the Corymorphidae, and Petersen (1979) elevated the Euphysinae to the rank of family. Bouillon (1985) recognized the Euphysidae and Boreohydridae as distinct families.

The family-group names Amalthaeidae Haeckel, 1879. and Steenstrupiini Cockerell, 1911, are synonyms of the Corymorphidae because their type genera, Amalthaea Schmidt, 1852, and Steenstrupia Forbes, 1846, are now generally considered congeneric with Corymorpha (e.g. . see Broch, 1916; Brinckmann-Voss, 1970; Millard, 1975; but also see Rees and Thursfield, 1965; Bouillon, 1985). Brinckmann-Voss (1970) has been followed in regarding the Paragotoeidae Ralph, 1959, as identical with the Corymorphidae. The family Euphysidae, including the Trichorhizini Cockerell, 1911, and Hypolytidae Fraser, 1943a, was considered valid by Petersen (1979) and Bouillon (1985). 
Hydroids of the families Corymorphidae and Tubulariidae Goldfuss, 1818, are obviously related, and several authors (e.g., Broch, 1916; Stechow, 1923a; Russell, 1953; Naumov, 1960; Kramp, 1961) have united the two. Differences between them are usually more pronounced in the hydroid stage than in the medusa. The family Corymorphidae is recognized as a distinct taxon in this report, a position held previously by authors such as Kramp (1949), Rees (1957), Brinckmann-Voss (1970), Vervoort (1972), Calder (1975), Millard (1975), Petersen (1979), and Bouillon (1985).

\section{Genus Zyzzyzus Stechow, 1921a}

Zyzzyzus Stechow, 1921a:249.

Zyzzvgus Neave, 1940a:712 [incorrect subsequent spelling]. Zyzzyzuz Bouillon, 1985:243 [incorrect subsequent spelling].

\section{DIAGNOSIS}

Corymorphid hydroids epizoic on sponges. Hydrocaulus parenchymatous, with endodernal canals, with rooting processes present basally, covered with thin perisarc. Hydranths radially symmetrical, with two whorls of tentacles; aboral tentacles long. filiform, in one whorl; oral tentacles relatively short, capitate in young hydroids, otherwise filiform, forming a band around hypostome.

Gonophores fixed sporosacs, arising from blastostyles distal to aboral tentacles, forming actinulae; hydroids monoecious.

\section{TYPE SPECIES}

Tubularia solitaria Warren, $1906 \mathrm{~b}$ (not Tubularia solitaria Rapp, 1829), by monotypy.

\section{REMARKS}

Stechow (1921a) founded Zyzzyzus to accommodate Tubularia solitaria Warren, 1906b (not Tubularia solitaria Rapp, 1829), a hydroid having characteristics of both the Corymorphidae Allman, 1872, and Tubulariidae Goldfuss, 1818. The genus was referred to the subfamily Corymorphinae, within the family Tubulariidae, by Stechow (1923a). Kramp (1933) initially regarded Zyzzyzus as congeneric with Corymorpha Allman, 1872, but concluded later (Kramp, 1949) that the genus was based on a species of Tubularia Linnaeus, 1758, which was adapted for life as an epizoite on sponges. Millard (1975), Watson (1978), Petersen (1979), and Bouillon (1985) recognized Zyzzyzus as valid, but referred it to the Tubulariidae rather than the Corymorphidae.

Zyzzyzus resembles Tubularia and the Tubulariidae mainly in having an actinula larva in its life cycle (Warren, 1906 b), but in most other respects it resembles Corymorpha and the Corymorphidae in my opinion. For example, the hydroid is strictly solitary; the hydrocaulus is thick and parenchymatous, with well-developed endodermal canals; the perisare is thin, soft, and flexible; and the internal anatomy of the hydranth is more like that of Corvmorpha M. Sars, 1835 (Allman, 1872; Rees, 1957) than that of Tubularia or the "lower corymorphines" (Grönberg. 1897; Rees, 1957). The gastrovascular cavity of the hydranth in Zyzzyzus is separated into oral and aboral chambers by a welldeveloped diaphragm (Fig. 38). For these reasons, the genus is included here in the Corymorphidae.

The absence of papillae on the hydrocaulus, the presence of one or more anchoring stolons basally, and the existence of an actinula larva in its life cycle distinguish Zyzzyzus from Corvmorpha.

Zyzzyzus warreni, nom. nov.

Figs. 38-40

Tubularia solitaria Warren, 1906b:83; pls. 10, 11 [invalid junior primary homonym of Tubularia solitaria Rapp, 1829 (not a hydroid)].

Zyzzyzus solitarius-Stechow, 1921 a:249.

Corymorpha solitaria-Kramp, 1933:12.

\section{TYPE LOCALITY}

Natal, South Africa.

\section{MATERIAL EXAMINED}

Flatts Inlet, on sponge, -1 to $-2 \mathrm{~m}, 13$ September 1977. several small hydroids, up to $5 \mathrm{~mm}$ high. some with developing blastostyles, ROMiz B133. Flatts Inlet, on sponges and Eudendrium carneum on underside of flat rock, $-3 \mathrm{~m}$, 2 August 1982, several hydroids, up to $10 \mathrm{~mm}$ high. with developing blastostyles, Romiz B 147. Castle Grotto, Castle Harbour, about $25 \mathrm{~m}$ inside cave entrance, on sponge, - $1 \mathrm{~m}$, 20 July 1982, several hydroids, up to $11 \mathrm{~nm}$ high. with gonophores, Romiz B 165. Stream Passage Cave, Harrington Sound, $3 \mathrm{~m}$ inside cave entrance, on sponge, $-1 \mathrm{~m}$, 20 June 1983, several hydroids, up to $17 \mathrm{~mm}$ high. with gonophores, ROMIz B370.

\section{DESCRIPTION}

Hydroids solitary, up to $17 \mathrm{~mm}$ high, usually embedded in sponge tissue basally. Base bulbous, lacking papillae but with one or more stout anchoring stolons of varying length. Hydrocaulus parenchymatous, with branching and anastomosing endodermal canals, reaching $1.5 \mathrm{~mm}$ wide basally, tapering distally. Perisarc thin, llexible, teminating just below hydranth in a distinct circular perisare groove. Hydranths up to $1.7 \mathrm{~mm}$ high. $1.5 \mathrm{~mm}$ wide, distinctly demareated from hydrocaulus, vasiform with two whorls of tentacles. Aboral tentacles filiform, reaching 
$3 \mathrm{~mm}$ long; oral tentacles much shorter, capitate in young polyps, otherwise filiform; tentacle number varying with hydranth size, larger hydranths with 22 to 25 aboral and 15 to 20 oral tentacles.

Blastostyles short, arising just distal to aboral tentacles, bearing clusters of fixed, cryptomedusoid gonophores. In examined specimens, gonophores incompletely developed, lacking actinulae.

Nematocysts-

Hydroids: desmonemes 3.7-4.2 $\mu \mathrm{m} \times 2.8-2.9 \mu \mathrm{m}$; isorhizas (ovate) $6.6-7.5 \mu \mathrm{m} \times 2.8-3.7 \mu \mathrm{m}$; ?isorhizas (reniform) 6.4-7.3 $\mu \mathrm{m} \times 1.9-2.1 \mu \mathrm{m}$; ?mastigophores 6.8$8.2 \mu \mathrm{m} \times 4.3-5.4 \mu \mathrm{m}$; microbasic euryteles 9.5-10.8 $\mu \mathrm{m}$ $\times 4.9-6.1 \mu \mathrm{m}$; stenoteles (small) 5.5-5.7 $\mu \mathrm{m} \times 4.5-$ $4.7 \mu \mathrm{m}$; stenoteles (medium) 6.7-7.3 $\mu \mathrm{m} \times 5.7-6.4 \mu \mathrm{m}$; stenoteles (large) $9.6-12.2 \mu \mathrm{m} \times 8.7-11.2 \mu \mathrm{m}$.

\section{REMARKS}

The name Tubularia solitaria Warren, I906b, is an invalid junior primary homonym of Tubularia solitaria Rapp, 1829 , and must be replaced [Art. 52]. Zyzzyzus warreni is proposed here as a new replacement name for Warren's taxon.

Zyzzyzus warreni resembles descriptions and illustrations of Tubularia spongicola von Lendenfeld, 1885b, by von Lendenfeld (1885b) and Watson (1978). According to Watson, Z. warreni differs from Z. spongicolus in having male and female gonophores on separate blastostyles instead of on the same ones. From existing descriptions, the two seem otherwise remarkably similar and may prove conspecific. According to Watson (1978), von Lendenfeld's ( $1885 \mathrm{~b}$ ) description and figure of $Z$. spongicolus do not correspond well with the type material, which she reexamined.

In Bermuda, this hydroid is usually, but not exclusively, epizoic on sponges. A few specimens were found attached to the hydrocaulus of the hydroid Eudendrium carneum Clarke, 1882, during this study (ROMIZ B 147).

Zyzzyzus warreni is evidently dormant during winter in Bermuda. No specimens were observed on a collecting trip in February and March 1982, although it was specifically looked for in areas where it was known to occur earlier and where it was collected on subsequent summer trips.

\section{ETYMOLOGY}

The replacement name for this species honours Ernest Warren, who first discovered and named this species, and who contributed significantly to knowledge of the hydroids of Natal.

\section{KNOWN RANGE}

Bermuda: first record.

Elsewhere: western Atlantic (Millard, 1975); eastern Atlantic (Ritchie, 1908); Indian Ocean (Millard, 1975).

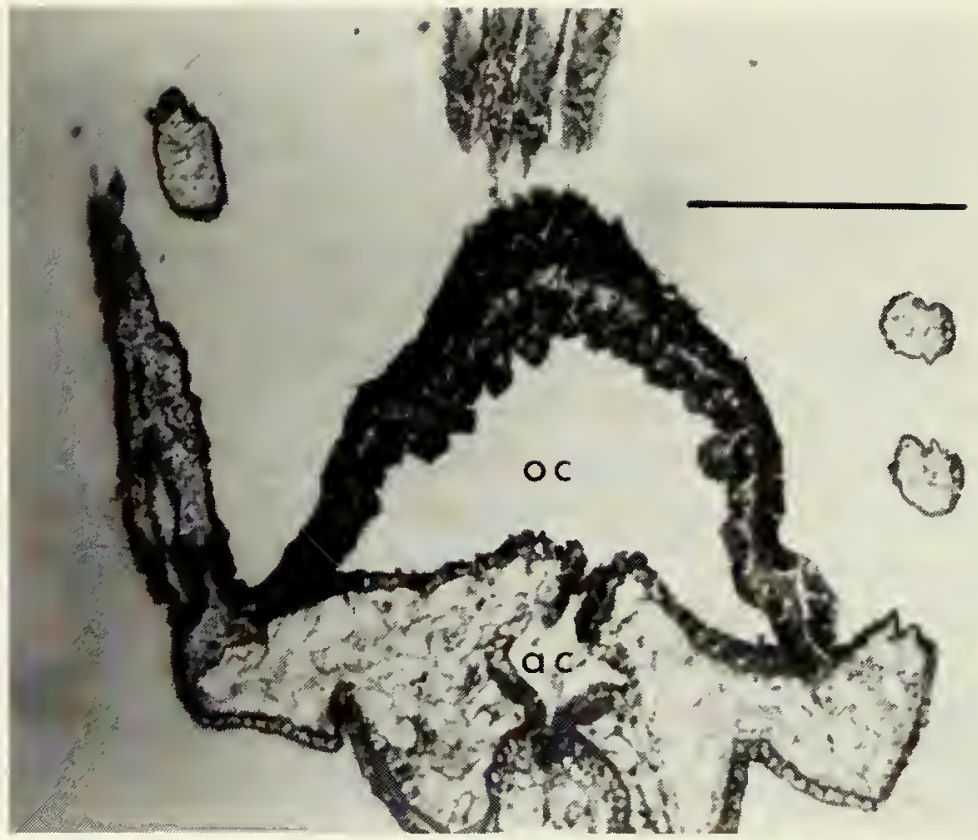

FlG. 38. Zyzzyzus warreni, photomicrograph of cross-section of hydranth, showing oral (oc) and aboral (ac) chambers separated by a well-developed diaphragm, ROMIz B 147. Scale equals $250 \mu \mathrm{m}$.

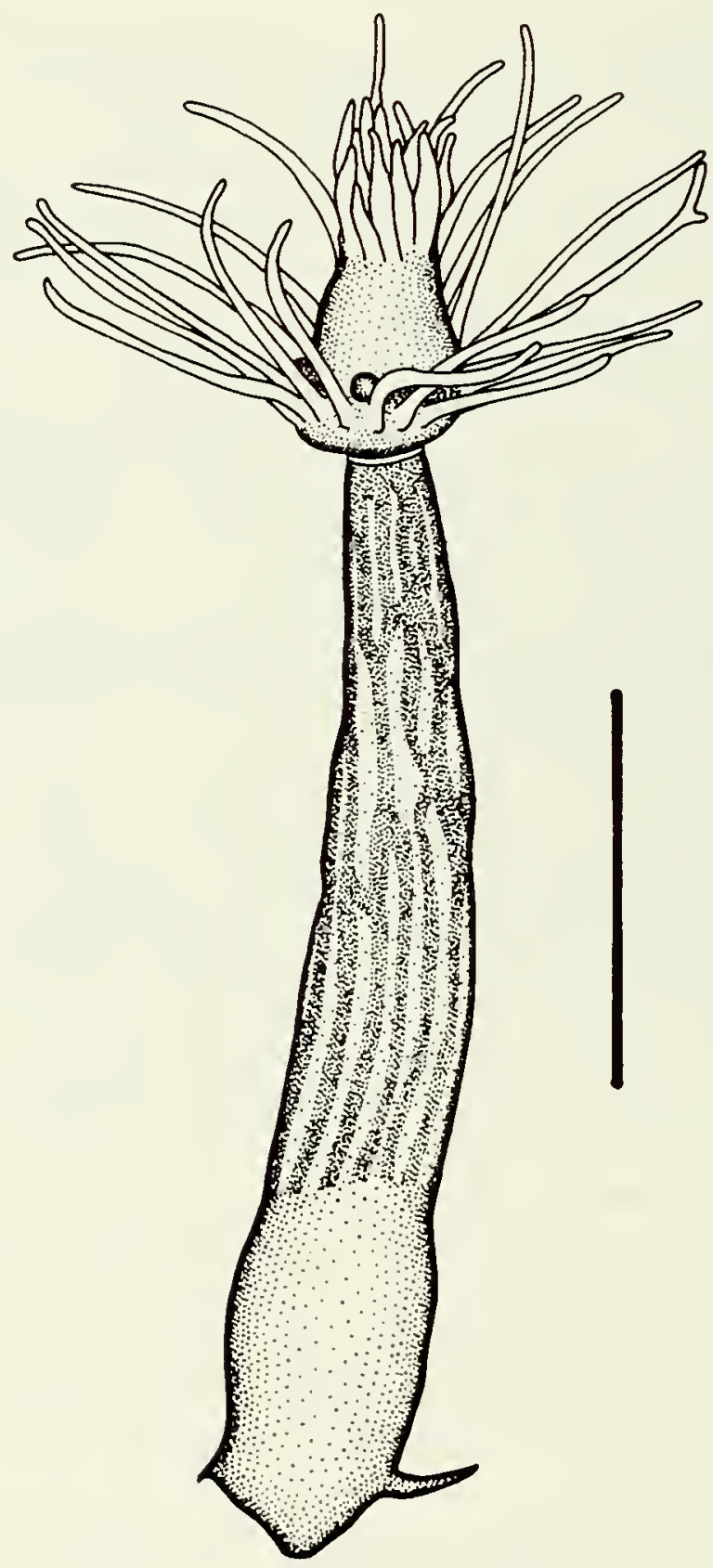

FiG. 39. Zyzzyzus warreni, hydroid, ROML B 147. Scale equals $2 \mathrm{~mm}$. 


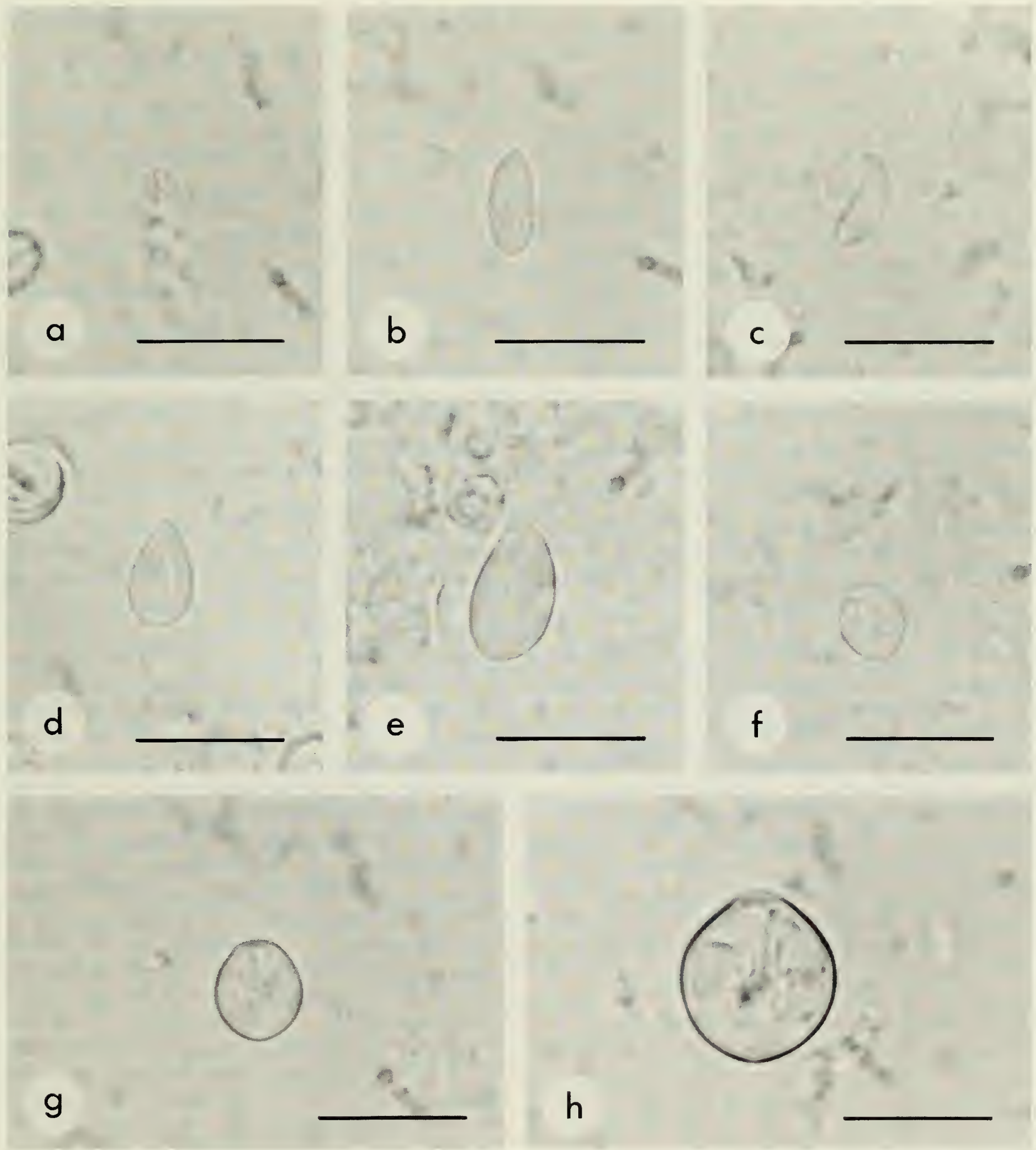

FIG. 40. Zyzzyzus warreni, nematocysts of hydranth, RomIz B 165. Scales equal $10 \mu \mathrm{m}$. a. Desmoneme. $b$, Ovate isorhiza. $c$, Reniform isorhiza. $d$, ?Mastigophore. $e$, Microbasic curytele. $f$, Small stenotele. $g$, Medium stenotele. $h$, Large stenotele. 


\section{Family Tubulariidae Fleming, 1828}

Tubulariadae Fleming. 1828:552 [corrected to Tubulariidae by Hincks, 1868].

Hybocodonidae Allman, 1872:421.

Hybdocoridae Pennington, 1885:71 [incorrect subsequent spelling of Hybocodonidae Allman. 1872].

\section{DIAGNOSIS}

Hydroids solitary or colonial. Hydrocaulus upright. cylindrical, invested with thick, rigid perisarc. Hydranths terminal, tlask-shaped, with oral and aboral whorls of tentacles. Oral tentacles relatively small, usually filiform in mature hydranths, capitate in immature ones; aboral tentacles large, filiform, in one whorl.

Gonophores fixed sporosacs or free medusae, borne on blastostyles arising from hydranth just distal to aboral tentacles: developmental stages including an actinula larva. Medusa, when present, bell-shaped; exumbrella with or without tracks of nematocysts; manubrium short, with simple, circular mouth. Radial canals four. Marginal tentacles one to four. Ocelli absent. Gonads surrounding manubrium.

\section{REMARKS}

Goldfuss (1818) appears to have been the first to establish a family-group taxon under the name "Tubulariae." Four genera were included in the group, Clava Gmelin, 1790, Coryne Gaertner, 1774, Calamella Oken, 1815, and Sertularia Linnaeus. 1758. The name, based on a genus excluded from the group, does not meet the criteria of availability [Art. IIf (i)(1)]. Goldfuss recognized the genus Tubularia Linnaeus, 1758, as valid, but it was included with a heterogeneous assemblage of invertebrate genera in another family, named the Polypi. Fischer von Waldheim (1823) also recognized a family "Tubulariae," but did not include Tubularia in the group. The family-group name Tubulariidae was first made available by Fleming (1828), as the Tubulariadae.

Allman (1872) founded the family Hybocodonidae to accommodate Hybocodon L. Agassiz, 1862, but the genus is now generally referred to the Tubulariidae (e.g., Millard, 1975; Petersen, 1979; Bouillon, 1985). Pennington (1885) incorrectly spelled this nominal family "Hybdocoridae."

There has been disagreement among hydrozoan systematists as to whether hydroids with fixed gonophores should be recognized as different genera from those producing free medusae, when other criteria supporting generic separation are lacking. The view that hydroids should not be referred to different genera if they differ only in gonophore type has heen advocated by authors such as Levinsen (1893), Broch (1916), Kramp (1949), and Petersen (1979). Conversely, Rees (1957:498) reviewed various points of view in the debate and concluded that "the use of separate genera is justifiable and the only suitable course for the vast majority of species in the present state of our knowledge."

The matter is of relevance in delimitation of several genera within the Tubulariidae. In most contemporary classifications, Ectopleura L. Agassiz, 1862, and Hybocodon L. Agassiz, 1862, are distinguished from Tubularia Linnaeus, 1758, chiefly in having free medusae instead of fixed gonophores. Ectopleura and Hybocodon in turn are distinguished on the basis of differences in the morphology of their medusae. These three genera were redefined by Petersen (1979) in a step towards a single classification system for the athecate hydroids and their medusae. Gonophores were considered in his scheme, but the presence or absence of a free medusa was not viewed as a diagnostic character at the generic level. He included in Tubularia those solitary species of tubularian hydroids producing either asymmetrical fixed gonophores or asymmetrical medusae. Under such a redefinition of the genus, Hybocodon becomes congeneric with Tubularia. Primitively colonial tubularian hydroids, having either symmetrical fixed gonophores or symmetrical medusae, were referred to the genus Ectopleura. Petersen's proposal eliminates vestiges of the illogical dual classification for hydroids and medusae in the Tubulariidae, and makes it possible to refer hydroids and medusae, independently of each other, to the appropriate genus. Further evaluation is needed to test whether it is tenable for all species of the family, and whether it constitutes a natural classification.

Significant advances have been made over the past three decades towards achieving a single classification of the Hydrozoa. Nevertheless, there is at present little alternative but to retain separate genera for many hydroids and hydromedusae until the identity and affinities of the two generations are resolved through life-cycle and systematic studies. Even when life cycles are known, serious difficulties may arise in formulating a single natural classification (Rees, 1957).

The definition adopted for Ectopleura, the only genus of the Tubulariidae known from Bermuda, is the conventional one followed by authors such as Brinckmann-Voss (1970), Millard (1975), and Bouillon (1985).

\section{Genus Ectopleura L. Agassiz, 1862}

Ectopleura L. Agassiz, 1862:342.

Acharadria Wright, 1863c:378.

Acharadrium Allman, 1872:376 [incorrect subsequent spelling].

Acharadia Brinckmann-Voss, 1970:25 lincorrect subsequent spelling].

Archaradia Bouillon, 1985:112 |incorrect subsequent spelling]. 


\section{DIAGNOSIS}

Primitively colonial hydroids, with the characters of the family.

Gonophores free medusae, with the characters of the family. Medusa radially symmetrical; exumbrella with eight longitudinal tracks of nematocysts; marginal tentacles two or four.

\section{TYPE SPECIES}

Tubularia dumortierii van Beneden, 1844b, by subsequent designation by Mayer (1910).

\section{REMARKS}

The genus Ectopleura was established by L. Agassiz (1862) to accommodate Tubularia dumortierii van Beneden, 1844b. and four other nominal species, including corynids as well as tubulariids. Agassiz did not designate a type species for the genus, but $E$. dumortierii was later so designated by Mayer (1910).

Brinckmann-Voss (1970) obtained medusae referable to Ectopleura from the hydroid of Acharadria larynx Wright, 1863c, type species of Acharadria. The name Acharadria Wright, 1863c, is, therefore, a junior synonym of Ectopleura.

\section{Ectopleura pacifica Thornely, 1900}

Figs. 41, 42

Ectopleura sp. Fewkes, 1883:85; pl. 1, fig. 11 [medusa] Ectopleura pacifica Thornely, 1900:452; pl. 44, figs. 1, la. Ectopleura minerva Mayer, 1900b:31; pl. 16, fig. 38; pl. 37, fig. 125 [medusa].

?Tubularia pacifica-Borradaile, 1905:838.

\section{TYPE LOCALITY}

Blanche Bay, New Britain, Papua New Guinea.

\section{MATERIAL EXAMINED}

Stream Passage Cave, Harrington Sound, on limestone wall, $-1.5 \mathrm{~m}, 27$ July 1982, one hydroid, $2.3 \mathrm{~cm}$ high, with blastostyles, ROMIz B 140. St George's Island, north shore, on mooring chain, $-9 \mathrm{~m}, 5$ October 1976, one colony, $2.5 \mathrm{~cm}$ high, with well-developed medusa buds, coll. J. Markham, L. Coen, Romiz B 164. Stream Passage Cave, Harrington Sound, on rock, - 1 m, 20 June 1983. one hydroid, $3.0 \mathrm{~cm}$ high, with medusa buds, ROM1z B369.

\section{DESCRIPTION}

Hydroids with creeping, branched hydrorhiza invested with thick, straw-coloured, smooth or occasionally wrinkled perisarc, giving rise to upright hydrocauli. Hydrocauli up to $2.5 \mathrm{~cm}$ high, $0.7 \mathrm{~mm}$ wide, invested with perisarc, widely separated or in small clumps, each with a single terminal hydranth. Perisarc straw-coloured, moderately thick basally, tapering to thin distally, terminating just below hydranth base. Hydranth vasiform, up to $1.8 \mathrm{~mm}$ high, $1.0 \mathrm{~mm}$ wide, bearing two whorls of tentacles. Aboral tentacles filiform, numbering 17 to 22 in mature hydranths, reaching $2 \mathrm{~mm}$ long; oral tentacles capitate, numbering 15 to 20 in mature hydranths, $0.3 \mathrm{~mm}$ long.

Gonophores free medusae, arising in clusters from short, slender blastostyles on hydranth just distal to aboral tentacles. Well-developed medusa buds dome-shaped, $2.8 \mathrm{~mm}$ high, $2.5 \mathrm{~mm}$ wide, with an apical projection; exumbrella with eight meridional tracks of nematocysts; mesoglea thin. Manubrium simple, tubular, reaching two-thirds distance to velar opening. Radial canals four. Tentacle bulbs four: two of these, opposite each other, bearing well-developed, capitate marginal tentacles.

Nematocysts-

Hydroids: desmonemes (on hydranths, medusa buds)
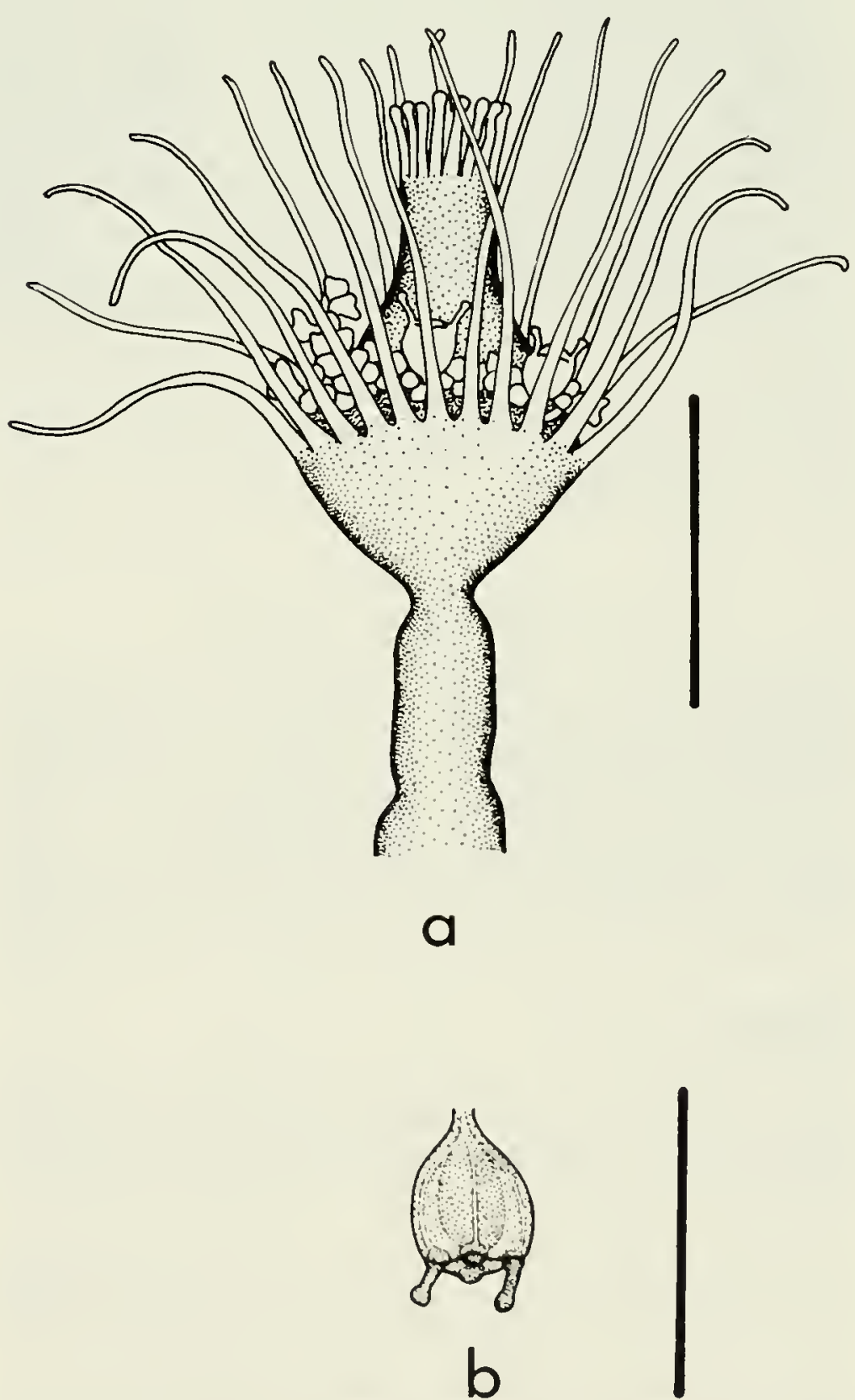

Fig. 41. Ectopleura parifica, Romiz. B 164. Scale for a equals $1 \mathrm{~mm}$; scale for b equals $0.5 \mathrm{~mm}$. (1. Hydranth with medusia buds. b. Medusa bud. 

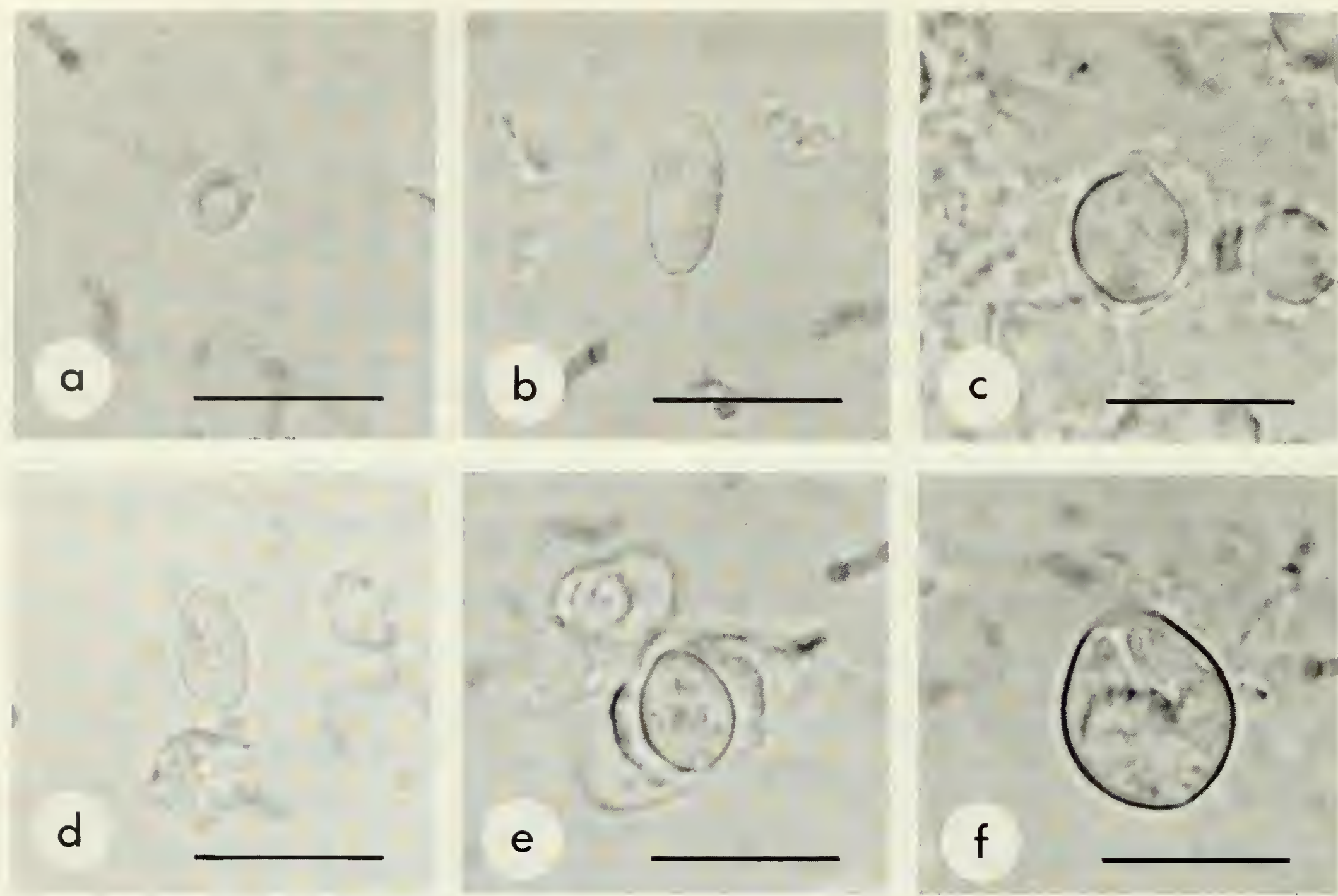

Fig. 42. Ectopleura pacifica, nematocysts of hydranth and medusa bud, Romiz B369. Scales equal $10 \mu \mathrm{m}$. $a$, Desmoneme of hydranth. $b$, ?Basitrichous isorhiza of hydranth. $c$, Heterotrichous anisorhiza of medusa bud. $d$, ?Microbasic mastigophore of medusa bud. $e$, Small stenotele of hydranth. $f$, Medium stenotele of hydranth.

4.6-4.9 $\mu \mathrm{m} \times 3.3-3.6 \mu \mathrm{m}$; ?basitrichous isorhizas (on hydranths) $8.3-9.1 \mu \mathrm{m} \times 3.7-4.0 \mu \mathrm{m}$; heterotrichous anisorhizas (on medusa buds) 7.3-7.8 $\mu \mathrm{m} \times 6.1-6.7 \mu \mathrm{m}$; ?microbasic mastigophores (on medusa buds) 6.8-7.5 $\mu \mathrm{m}$ $\times$ 3.4-3.8 $\mu \mathrm{m}$; stenoteles (small) (on hydranths, medusa buds) $6.5-7.3 \mu \mathrm{m} \times 4.9-6.6 \mu \mathrm{m}$; stenoteles (medium) (on hydranths, medusa buds) $9.3-11.9 \mu \mathrm{m} \times 8.0-9.8 \mu \mathrm{m}$

\section{REMARKS}

Thornely (1900) described Ectopleura pacifica from a hydroid collected off New Britain in the western Pacific. Hydroids from Bermuda correspond in all respects to Thornely's original description of this species. While recognizing that major zoogeographic barriers separate these Bermudian hydroids from the type locality of $E$. pacifica (see Ekman, 1953; Briggs, 1974), I nevertheless regard them as conspecific based on morphological evidence.

Mayer (1900b) applied the name Ectopleura minerva to medusae collected at the Tortugas, Florida. The same species had earlier been reported from Bermuda by Fewkes
(1883), as Ectopleura sp. Neither Mayer nor Fewkes observed the hydroid of E. minerva, but their descriptions of the medusa are applicable to medusa buds in present material (ROMIz B164) and to Thornely's (1900) description of $E$. pacifica, and the two are regarded here as conspecific. The name $E$. pacifica has priority over $E$. minerva because Thornely's (1900) account of the former appeared in May, while Mayer's (1900b) report of the latter appeared in July.

Free medusae ascribed to Ectopleura pacifica have been reported in the literature only by Mammen (1963) and Calder (1986), the latter based on Fewkes's (1883) record of Ectopleura sp. from Bermuda. Mammen's identification is believed to be wrong because his medusa bore four equally developed tentacles instead of two, and the oral tentacles of his hydroid were filiform instead of capitate. Notably, however, medusae identified as $E$. minerva have been reported from several locations in the Indian Ocean and the western Pacific (Nair, 1951; Kramp, 1965, 1968; Sugiura, 1977; Bouillon, 1978a, 1978c). 
Hydroids of Ectopleura pacifica resemble descriptions of E. larynx (Wright, 1863c). In both species, hydroids are small and "primitively" colonial with capitate oral tentacles, and the medusa buds have two tentacles instead of four. In spite of these similarities, the two are regarded as separate species here because of apparent differences in their morphology. In hydroids of E. larynx, only 2 to 8 oral tentacles and 4 to 16 aboral tentacles have been observed on the hydranth (Wright, 1863a, 1863c; Brinckmann-Voss, 1970), far fewer than in E. pacifica.
Brinckmann-Voss (1970) believed that E. larynx and E. minerva were different species based on the shape of the medusa.

\section{KNOWN RANGE}

Bermuda: Castle Harbour, medusa stage (Fewkes, 1883); inshore on floats and offshore on buoy chains (Calder, 1986).

Elsewhere: western Atlantic (Mayer, 1900b); Indian Ocean (Jarvis, 1922); western Pacific (Sugiura, 1977).

\section{Family Halocordylidae Stechow, 1921a}

Halocordylidae Stechow, 1921 a:249.

\section{DIAGNOSIS}

Colonial, capitate hydroids with creeping hydrorhiza and upright, pinnately branched hydrocaulus bearing branches on upper side only. Perisare tubular, thick, and firm. Hydranths terminal, clavate to pear-shaped, each with an aboral whorl of long, filiform or slightly capitate tentacles, an oral whorl of short capitate tentacles, and one or more distinct or indistinct whorls of short capitate tentacles between.

Gonophores borne just distal to aboral tentacles, either liberated as short-lived medusae or remaining attached to hydranth as eumedusoids. Medusa thimble-shaped with thin mesoglea; manubrium short; mouth lacking. Radial canals four. Tentacle bulbs four; tentacles rudimentary or absent. Ocelli present or absent. Gonads surrounding manubrium.

\section{REMARKS}

Stechow (1921a) proposed that the name Pennariidae McCrady, 1859a, as applied to this taxon, be replaced for reasons elaborated upon in subsequent publications (Stechow, 1922, 1923a). In these last two papers, he noted that the type genus Pennaria Oken, 1815, originally included eight species, five of which were thecates and the other three of which were of indeterminable identity. Stechow noted that the name Pernaria should not have been applied later by Goldfuss (1820) to two species of athecate hydroids, including the faniliar Pennaria disticha. He recognized Halocordyle Allman, 1872, as the valid name of the genus, and established the name Halocordylidae for the family. This family name has now gained widespread use (e.g., Rees, 1957; Pennycuik, 1959; Vervoort, 1959; Mammen, 1963; Calder, 1971; Cooke, 1975; Millard, 1975; Hirohito, 1977; Petersen, 1979; Bouillon, 1985; GarciaCorrales and Aguirre, 1985). The family names Pennariidae and Halocordylidae cannot be regarded as synonyms because the nominal genera Pennaria and Halocordyle are not even in the same order.
Pennaria Oken, 1815, is invalid on grounds in addition to those noted by Stechow (1922, 1923a). Oken's (1815) publication has been rejected for nomenclatural purposes by the ICZN (Opinion 417) because it did not consistently adhere to the Principle of Binominal Nomenclature [Art. 5a].

Halocordyle Allman, 1872, type genus of the family Halocordylidae, is regarded as congeneric with Eucoryne Leidy, 1855. For reasons noted below (see p. 56), usage of the junior synonym Halocordyle as the name of the genus is maintained in this report. The name Halocordylidae is retained as the valid name of the family.

Ten genera were included in the family Halocordylidae by Stechow (1923a). With the exception of the type genus, all have since been transferred to other families (Mammen, 1963). Hydroids of this family are unusual among the Athecatae in their regularly pinnate colony form (Brinckmann-Voss, 1970; Millard, 1975).

\section{Genus Halocordyle Allman, 1872}

Pennaria auct. Inot Pennaria Oken, 1815:93 (invalid name, published in a work rejected for nomenclatural purposes by the ICZN, Opinion 417)].

Globiceps Ayres, 1854:193 [invalid junior homonym of Globiceps Le Peletier de Saint-Fargeau and Serville, 1825 (Hemiptera)].

Eucoryne Leidy, 1855:136.

Eucoryna van Beneden, 1867:17 incorrect subsequent spelling].

Halocordyle Allman, 1872:368.

Halocordile Wedler and Larson, 1986:69 |incorrect subsequent spelling].

\section{DIAGNOSIS}

With the characters of the family.

TYPE SPECIES

Globiceps tiarella Ayres, 1854, by monotypy, a junior subjective synonym of Pennaria disticha Goldfuss, 1820. 


\section{REMAKKS}

The invalid name Pennaria Oken, 1815, came into widespread use for this genus after Goldfuss (1820) referred his familiar species $P$. disticha to it. As noted above, Pennaria originally included five thecate species and three other species of indeterminable identity (Stechow. 1922. 1923a).

The binomen "Sertolara pennara" had earlier been applied by Cavolini (1785) to the hydroid referred to by Goldfuss (1820) as Pennaria disticha. Cavolini obviously believed his material was conspecific with Sertularia pennaria Linnaeus, 1758, but the latter is now known to be a species of thecate hydroid (see p. 57). Sertolara as used by Cavolini is an incorrect subsequent spelling of Sertularia Linnaeus, 1758. As such, it is an unavailable name [Art. 33c] and cannot be used as the name of this genus.

Ayres (1854) founded the name Globiceps tiarella for an American hydroid now generally regarded as conspecific with Pennaria disticha. The name Globiceps Ayres, 1854, cannot replace Pennaria auct. because it is an invalid junior homonym of Globiceps Le Peletier de Saint-Fargeau and Serville, 1825, a name applied to a hemipteran ( $\mathrm{L}$. Agassiz, 1862; Allman, 1872).

One year after the publication of the name Globiceps tiarella, Leidy (1855) described the same species under the name Eucoryne elegans. L. Agassiz (1862) and Allman (1872) believed that the name Eucoryne Leidy, 1855, was preoccupied by Eucorynus Schoenherr, 1823, a coleopteran. Allman (1872) proposed Halocordyle as a substitute name for Globiceps Ayres, 1854, and Eucoryne Leidy, 1855. However, Eucoryne Leidy, 1855, and Eucorynus Schoenherr, 1823, are not homonyms [Art. 56b]. Euconne, seldom used as a valid name since it was published (e.g. see Bedot, 1910, 1912, 1916, 1918, 1925), is nonetheless available as a senior synonym of Halocordyle, now in widespread use (e.g., see the 11 works cited above to demonstrate widespread use of the family name Halocordylidae). In the interests of nomenclatural stability, a submission will be made to the ICZN requesting suppression of the genus name Eucoryne Leidy, 1855, and placement of the name Halocordyle Allman, 1872, on the Official List of Generic Names in Zoology.

\section{Halocordyle disticha (Goldfuss, 1820)}

Figs. 43-45

Sertolara pennara-Cavolini, 1785:134; pl. 5, figs. 1-6 [incorrect subsequent spelling] [not Sertularia pennaria Linnaeus, 1758].

Sertularia pennaria-Gmelin, 1790:3856 [not Sertularia pennaria Linnaeus, 1758].

Pennaria disticha Goldfuss, 1820:89.

Plumularia pennaria-de Blainville, 1830:442.

Pennaria cavolinii Ehrenberg, 1834:297.
Aglatophenia pinnaria-Costa, 1839:185 [incorrect subsequent spelling].

Pennaria canlini delle Chiaje, 1841:145.

Anisocalyx pinnarium-Costa, 1842:18.

Globiceps tiarella Ayres, 1854:193.

Eucoryne elegans Leidy, 1855:136; pl. 10, figs. 1-5.

?Euphysa globator Leuckart, 1856:28; pl. 2, fig. 4 [medusa].

Pennaria tiarella-McCrady, 1859a:153.

Pennaria gibbosa L. Agassiz, 1860, pl. 15, figs. 1,2.

Pennaria distycha-L. Agassiz, 1862:344 [incorrect subsequent spelling].

Eucoryna elegans - van Beneden, 1867:17 [incorrect subsequent spellingl.

Pennaria cavolini-van Beneden, 1867:50 [incorrect subsequent spelling].

Halocordyle tiarella-Allman, 1872:369.

Pennaria symmetrica Clarke, 1879:240; pl. 1, figs. 2,3. Globiceps globator-Haeckel, 1879:40 [medusa].

Pennaria inornata Brooks, 1883a: 144.

Pennaria australis Bale, 1884:45.

Pennaria rosea von Lendenfeld, 1885b:594; pl. 24, figs. 40-42.

Pennaria adamsia von Lendenfeld, 1885b:595; pl. 25. figs. 45-48; pl. 26, fig. 49.

Pennaria pennaria-Marktanner-Turneretscher, 1890:201. Halocordyle australis Bale, 1894:94.

Pennaria cavolina-Spencer, 1892:13 [incorrect subsequent spelling].

Halocordyle cooperi Warren, 1906a:73; pl. 9.

Pennaria pacifica Clarke, 1907:6; pl. 1, figs. 1-6.

Pennaria australis var. cooperi-Warren, 1908:282.

Pennaria anstralis-Warren, 1908:283.

Pennaria disticha var. australis-Ritchie, 1910a:806.

Pennaria wilsoni Bale, 1913:116.

Halocordyle disticha-Stechow, 1923a:48.

Halocordyle australis-Stechow, 1923a:48.

Halocordyle wilsoni-Stechow, 1923a:48.

Corydendrium splendidum Boone, 1938:33; pl. 4.

Halocordyle disticha var. australis-Vervoort, 1941:192.

Halocordyle fragilis Vannucci, 1951:76; pl. 1, figs. 2.3.

Halocordyle pennaria var. australis-Mammen, 1963:54; figs. 22-24.

Pennaria "americana" Garcia-Corrales and Aguirre, 1985:86 [nomen nudum].

Pennaria (Halocordyle) tiarella-Garcia-Corrales and Aguirre, 1985:86.

Pennaria "europea" Garcia-Corrales and Aguirre, 1985:86 [nomen nudum].

Pennaria (Halocordyle) disticha-Garcia-Corrales and Aguirre, 1985:86.

Pennaria symetrica-Garcia-Corrales and Aguirre, 1985:86 [incorrect subsequent spelling].

Halocordile disticha-Wedler and Larson, 1986:69 [incorrect subsequent spelling!. 


\section{TYPE LOCALITY}

Gulf of Naples, Italy.

\section{MATERIAL EXAMINED}

Castle Harbour near Tucker's Town, on patch reef, $-7 \mathrm{~m}$, 3 August 1982, two colonies, 6.7 and $10.2 \mathrm{~cm}$ high, with well-developed medusa buds, ROMIZ B131. Flatts Inlet, on underside of flat rocks, $-3 \mathrm{~m}, 2$ August 1982, one colony, $2.2 \mathrm{~cm}$ high, without gonophores, ROMIZ B 143 . Whalebone Bay, on ledges at entrance, $-1 \mathrm{~m}, 4$ March 1982, two colonies, 2.6 and $3.1 \mathrm{~cm}$ high, without gonophores, ROMIZ B 167.

\section{DESCRIPTION}

Colonies erect, arising from a creeping, branching hydrorhiza; growth monopodial with terminal hydranths. Hydrocaulus monosiphonic, reaching about $0.4 \mathrm{~mm}$ wide, zigzag to nearly straight, annulated basally, divided at more or less regular intervals by one or more well-developed annulations; internodes $0.6-4.0 \mathrm{~mm}$ long, each typically supporting a branch distally. Perisarc thick, black through brown to deep horn-coloured basally, becoming progressively thinner and lighter coloured distally, terminating abruptly below hydranths of hydrocaulus, branches, and ramuli. Branches up to $27 \mathrm{~mm}$ long, annulated basally, given off alternately from opposite sides of hydrocaulus, curved outwards, divided into internodes; these internodes 1.5-4.0 mm long, marked by distinct to rather faint annulations proximally and distally; each internode giving rise to a ramulus from both its upper surface and its distal end. Ramuli unbranched, annulated basally or throughout entire length, each terminating in a hydranth. Hydranths clavate to pear-shaped, up to $1.7 \mathrm{~mm}$ long, $0.3 \mathrm{~mm}$ wide; with a whorl of about 10 to 16 long, filiform or faintly knobbed tentacles aborally; a varied number of short, capitate tentacles in one or more regular or irregular verticils medially; and a whorl of about four to six short, capitate tentacles orally. Hypostome dome-shaped.

Nematocysts-

Hydroids: desmonemes $4.5-5.3 \mu \mathrm{m} \times 3.3-3.8 \mu \mathrm{m}$; basitrichous haplonemes 5.7-9.4 $\mu \mathrm{m} \times 2.5-3.6 \mu \mathrm{m}$; heterotrichous microbasic euryteles $10.8-13.6 \mu \mathrm{m} \times 6.1-$ $6.8 \mu \mathrm{m}$; stenoteles (very small) 5.7-6.6 $\mu \mathrm{m} \times 4.3-4.6 \mu \mathrm{m}$; stenoteles (small) 7.4-7.8 $\mu \mathrm{m} \times 5.5-5.7 \mu \mathrm{m}$; stenoteles (medium) $14.2-17.7 \mu \mathrm{m} \times 10.0-12.0 \mu \mathrm{m}$; stenoteles (large) $28.1-39.8 \mu \mathrm{m} \times 16.3-20.2 \mu \mathrm{m}$.

Gonophores free but degenerate medusae, those of a given colony either all male or all female, arising on short pedicels just distal to aboral tentacles. Well-developed medusa buds elongate-oval, about $0.9 \mathrm{~mm}$ high, $0.6 \mathrm{~mm}$ wide, covered with an ectodermal sheath; mesoglea thin; manubrium simple, tubular, reaching nearly to velar opening. Radial canals four. Tentacle bulbs four, reduced; tentacles reduced. Ocelli lacking. Gonads surrounding manubrium, filling subumbrellar cavity.

Nematocysts-

Medusa buds: heterotrichous microbasic euryteles 7.5$8.3 \mu \mathrm{m} \times 3.1-4.0 \mu \mathrm{m}$.

\section{REMARKS}

There has been some question as to whether Sertularia pennaria Linnaeus, 1758, may belong to the same species as this hydroid (e.g., see Cavolini, 1785; L. Agassiz, 1862; Marktanner-Turneretscher, 1890; Bedot, 1901; Mayer, 1910). Bedot (1912) reported that the Linnaean species is an Aglaophenia Lamouroux, 1812, rather than an athecate hydroid. Examination of the Linnaean type has confirmed Bedot's (1912) conclusion (P. F. S. Cornelius, pers. comm.) that it is an aglaopheniid.

The oldest available specific name for this well-known species is that of Goldfuss (1820), who applied the name Pennaria disticha to Cavolini's (1785) "Sertolara pennara." Cavolini's hydroid was identical with what is widely referred to today as Halocordyle disticha (Goldfuss, 1820) and Pennaria tiarella (Ayres, 1854), rather than Linnaeus's (1758) Sertularia pennaria.

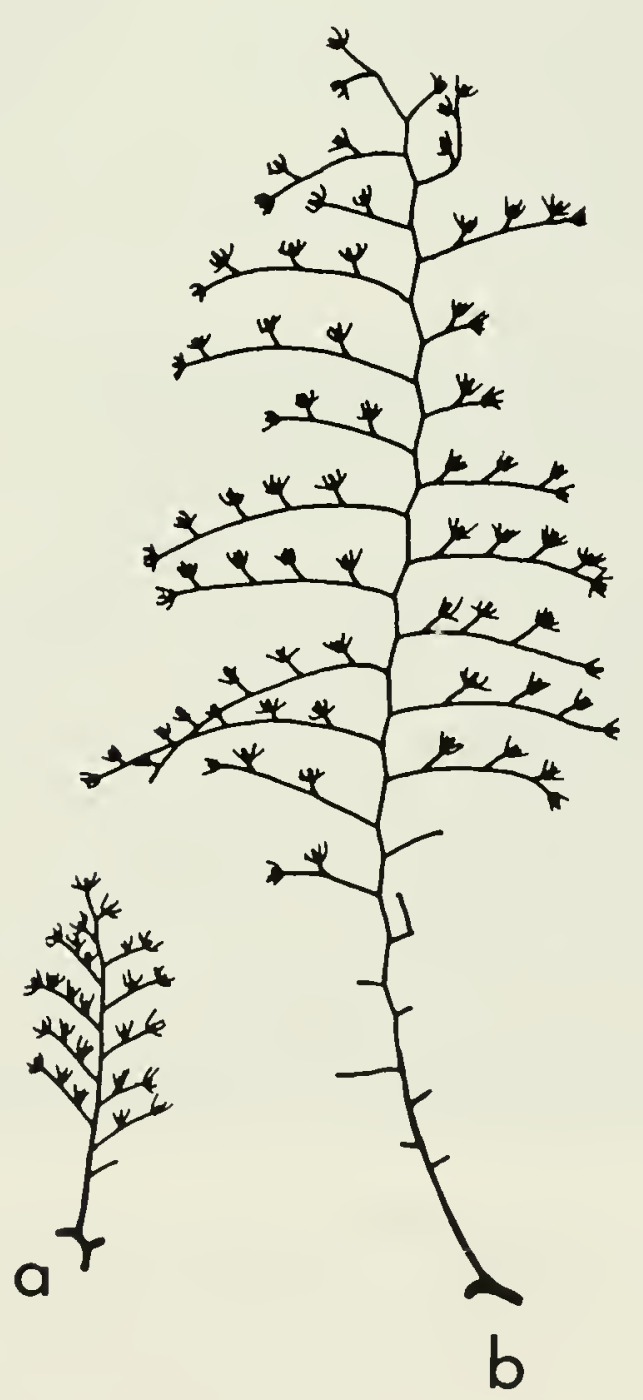

Fig. 43. Halocordyle disticha, colony form. Natural size. a. Colony from exposed area, Romiz BI67. b, Colony from sheltered area, Romiz B131. 

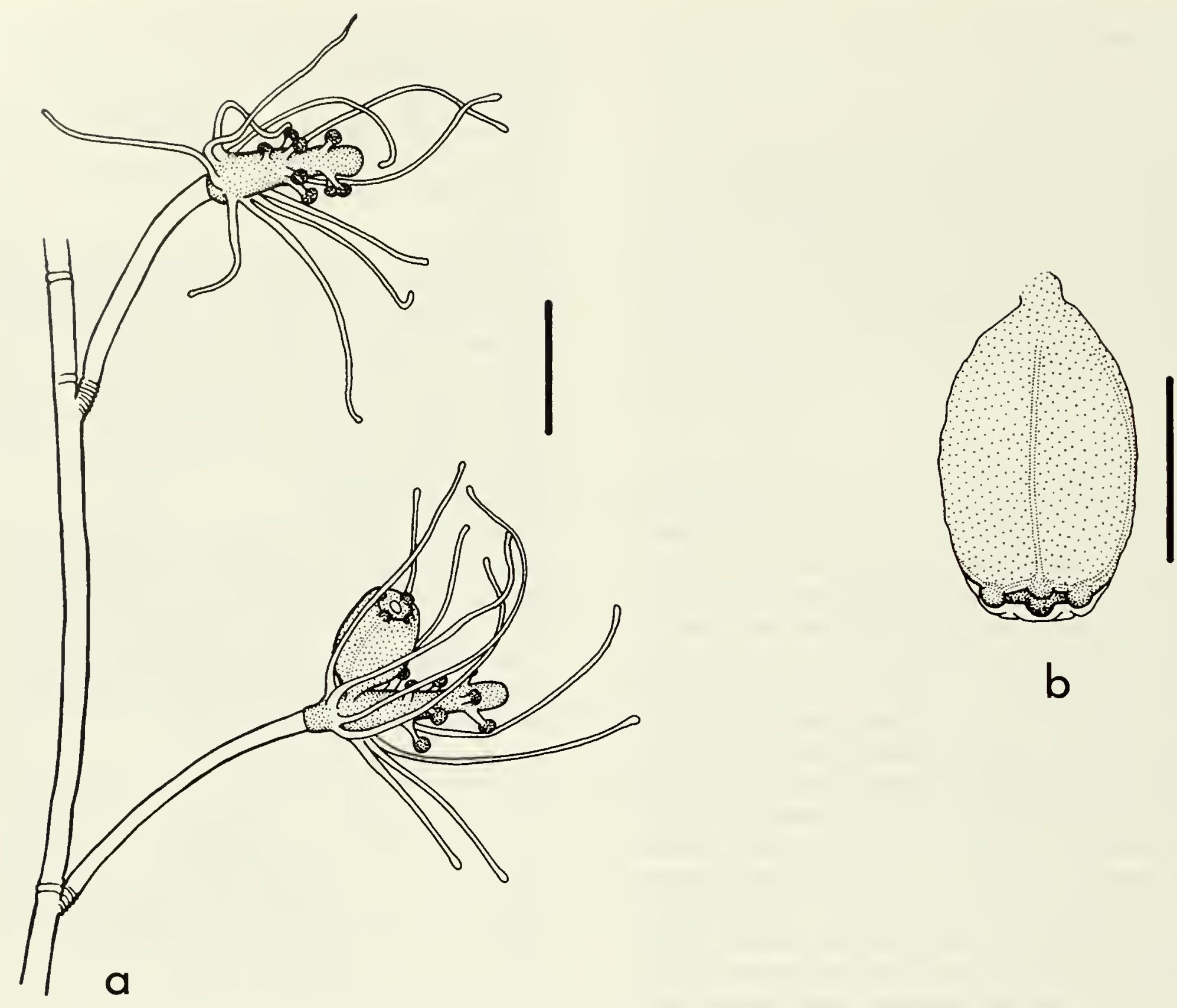

FIG. 44. Halocordyle disticha, ROMIz B131. Scale for $a$ equals $1 \mathrm{~mm}$; scale for $b$ equals $0.5 \mathrm{~mm}$. $a$, Hydrocaulus and hydranths. $b$, Medusa bud.

The synonymy list provided above has been taken largely from Bedot (1901, 1905, 1910, 1912, 1916, 1918, 1925), Mayer (1910), Millard (1975), Cooke (1977), Hirohito (1977), and Garcia-Corrales and Aguirre (1985). The last two papers included extensive discussion of the synonymy of Halocordyle disticha, and the matter will not be repeated here. In neither paper, however, was it noted that Bale (1894) had described Halocordyle australis as a different species from Pennaria australis Bale, 1884. Both nominal species are included here in the synonymy of Halocordyle disticha.

Colonies of Halocordyle disticha displayed considerable variation in form from one location to another in Bermudian waters (Fig. 35). Specimens from sheltered waters near the base of a patch reef in Castle Harbour (ROMIZ B 131) were large and gracile. Internodes of both hydrocaulus and branches were long and slender, and the branches and ramuli were elongate. Specimens from wave-swept ledges at the entrance of Whalebone Bay (ROMIZ B167), as well as those subjected to strong tidal currents near the bridge at Flatts Inlet (ROMIZ B143), were small and compact. Internodes of the hydrocaulus and hydrocladia in these colonies were thicker and much shorter, and the branches and ramuli were relatively stunted. The degree of annulation on stem and branches, a variable character in this species (Millard, 1975), did not appear to differ significantly from one colony form to another in Bermudian material.

Hydroids of Halocordyle disticha are inactive during colder months in temperate areas (Hargitt, 1900; McDougall, 1943; Brinckmann-Voss, 1970; Calder, 1971). In Bermuda, a few colonies with active hydranths were found in winter even at water temperatures as low as $17^{\circ} \mathrm{C}$, but the species was observed in far greater abundance during the warmer seasons.

Medusae of this species are short-lived and are liberated 

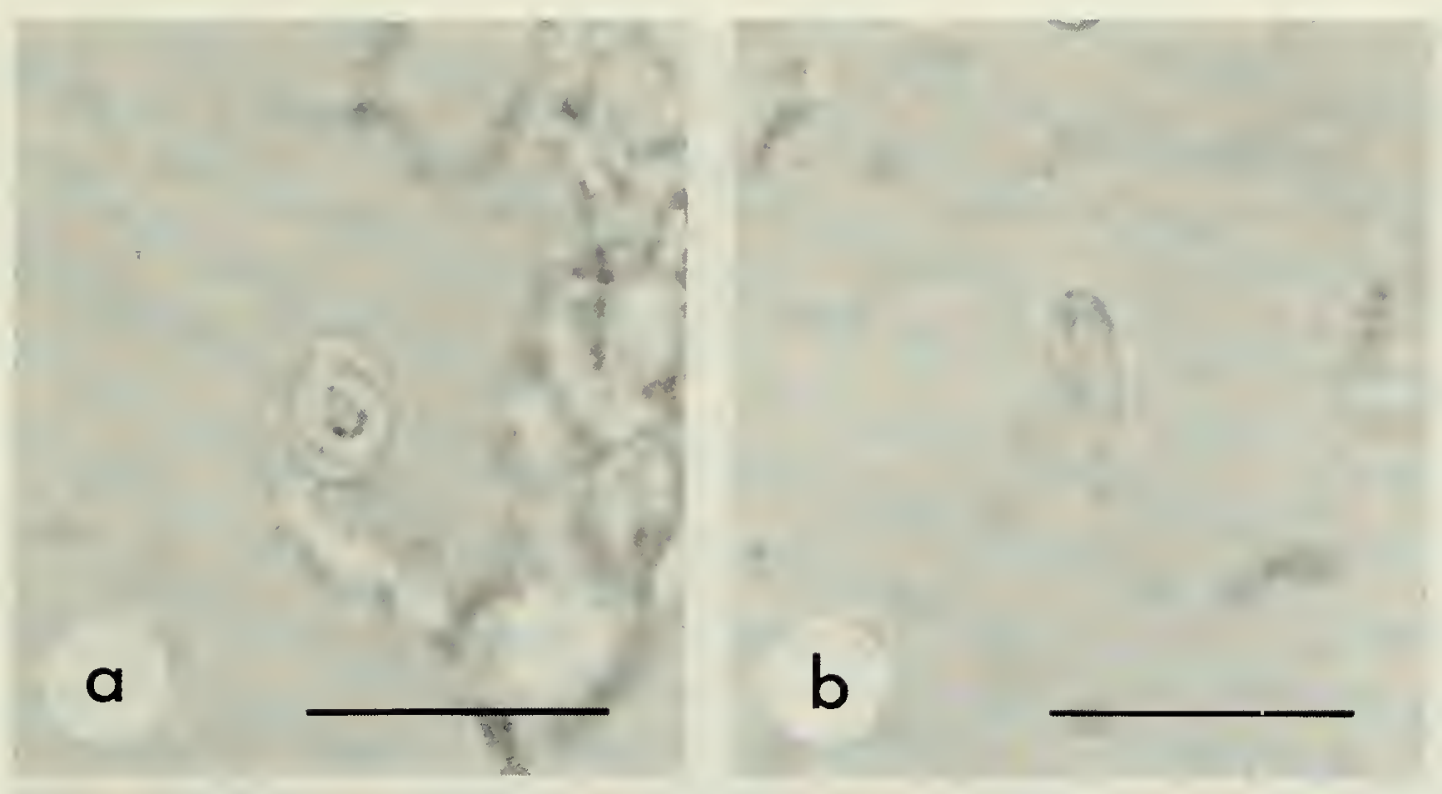

b

C
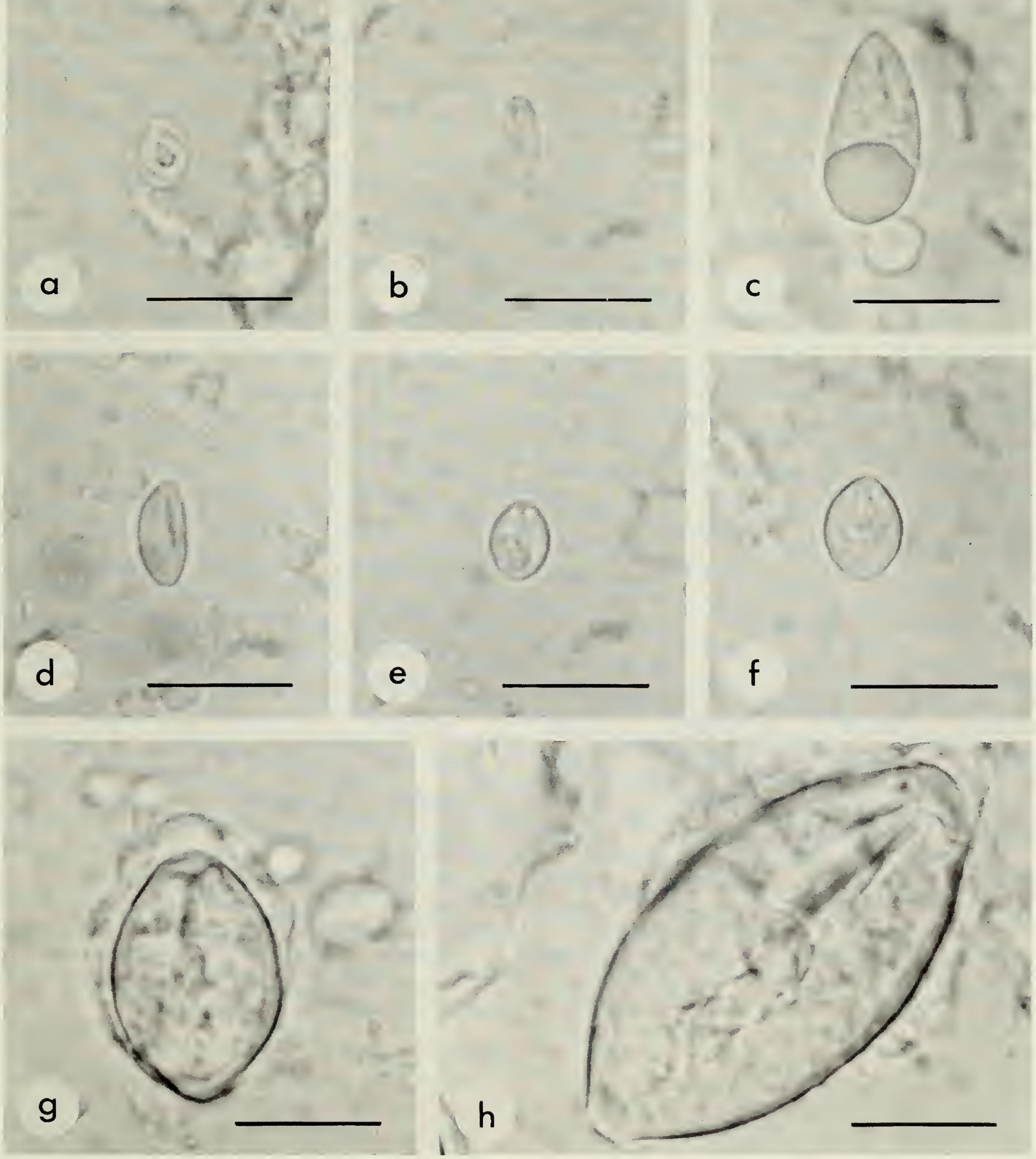

Fig. 45. Halocordyle disticha, nematocysts of hydranth and medusa bud. Scales equal $10 \mu m$. a, Desmoneme of hydranth, ROMIz B 143. b, Basitrichous haploneme of hydranth, ROMIz B143. c, Heterotrichous microbasic eurytele of hydranth, кOMIz B143. $d$. Heterotrichous microbasic curytele of medusa bud. kOMIz B131. e, Very small stenotele of hydranth, ROMIZ B143. $\int$. Small stenotele of hydranth, Roniz, B143. g. Medium stenotele of hydranth, ROMiz B 167. h, Large stenotele of hydranth. ROMiz B167. 
in the evening in Bermuda (Weill, 1937a), as noted in specimens from Chesapeake Bay (Calder, 1971). BrinckmannVoss (1970) and others noted that medusa buds of Halocordyle disticha often shed their gametes while attached to the hydroid and are sometimes not released. The phenomenon of egg release by attached medusa buds in this species was described by Cavolini (1785), as noted by Cornelius (1977).

According to Weill (1934), the cnidome of hydroids of this species included desmonemes, stenoteles, microbasic mastigophores, and heteronemes of an undetermined category. Bouillon (1985) has been followed here in regarding the last two of these as microbasic euryteles and basitrichous haplonemes. The nematocyst complement of medusa buds in Bermudian material typically consisted of microbasic euryteles, although a few stenoteles and haplonemes were observed in some specimens. Euryteles of medusa buds almost always lacked the spherical inclusions found in those of the hydroid.

This species has been reported from Bermuda several times previously (Verrill, 1900; Congdon, 1907; Bennitt, 1922; Calder, 1986). It has also been utilized in morphological and developmental studies conducted at the Bermuda Biological Station (Weill, 1937a; Cowden, 1964, 1965a, 1965b; Summers and Haynes, 1969; Summers, 1970, 1972b; Lesh-Laurie, 1976; Clark and Cook, 1986).

\section{KNOWN RANGE}

Bermuda: no specific locality given (Verrill, 1900: Congdon, 1907; Weill, 1937a); Hamilton Harbour and Great Sound (Bennitt, 1922); near the Bermuda Biological Station (Cowden, 1964, 1965a, 1965b); Flatts Inlet (Summers and Haynes, 1969; Summers, 1970, 1972b; Lesh-Laurie, 1976); inshore in shallow water and offshore on buoy chains (Calder, 1986).

Elsewhere: western Atlantic (Fraser, 1944); eastern Atlantic (Brinckmann-Voss, 1970); Indian Ocean (Millard, 1975); western Pacific (Yamada, 1959); eastern Pacific (Fraser, 1948).

\section{Family Sphaerocorynidae Prévot, 1959}

Sphaerocorynidae Prévot, 1959:108.

\section{DIAGNOSIS}

Hydroids colonial, with creeping stolons and upright, unbranched or sparingly branched hydrocauli with terminal hydranths. Perisarc moderately thin, reaching to hydranth base. Hydranths pyriform, with bulbous base and conical hypostome. Tentacles capitate, scattered in an irregular band about bulbous hydranth base.

Gonophores free medusae, arising from hydranth on short pedicels among or distal to tentacles. Medusae bellshaped, with or without exumbrellar nematocyst tracks; manubrium tubular in juveniles, cruciform in cross-section in adults, not extending beyond velar opening; mouth simple. Radial canals four. Marginal tentacles two or four, capitate. Ocelli present. Gonads on perradii of manubrium.

\section{REMARKS}

Sphaerocoryne Pictet, 1893, and Linvillea Mayer, 1910. the latter a genus formerly included in the family Corynidae Johnston, 1836, were grouped by Petersen (1979) in the Sphaerocorynidae Prévot, 1959. Petersen noted that these genera differ in several respects from typical corynid hydrozoans. Tentacles in the hydroid stage are restricted to the expanded basal region of the hydranth, and medusa buds arise among or distal to the tentacles. Gonads in the medusa do not surround the manubrium but are located perradially on it. Finally, the nematocyst complement of both hydroid and medusa includes stenoteles and desmo- nemes. Petersen believed that this family was more closely related to the Moerisiidae Poche, 1914, than to the Corynidae as suggested by Prévot (1959).

\section{Genus Sphaerocoryne Pictet, 1893}

Sphaerocoryne Pictet, 1893:9.

\section{DIAGNOSIS}

Hydroids with the characters of the family.

Medusa buds arising in clusters on hydranth just distal to tentacles. Medusae with scattered exumbrellar nematocysts; manubrium of adult somewhat cruciform in crosssection. Marginal tentacles four, capitate or moniliform, equally developed at liberation.

\section{TYPE SPECIES}

Sphaerocoryne bedoti Pictet, 1893, by monotypy.

\section{REMARKS}

The hydroids of Sphaerocoryne Pictet, 1893, and Linvillea Mayer, 1910, resemble one another morphologically. Yamada and Konno (1973) reported finding only minor differences in a comparison of Sphaerocoryne multitentaculata (Warren, 1908) $(=$ S. bedoti Pictet, 1893) from Japan and Linvillea agassizii (McCrady, 1859a) from Virginia, United States. Medusa buds in L. agassizii arise among the tentacles on the hydranth, while they occur distal to the ten- 
tacles in $S$. bedoti. Differences are more pronounced in medusae of the two species. In L. agassizii, medusae have eight exumbrellar nematocyst tracks, the manubrium is distinetly cruciform in cross-section in the adult, and two of the four marginal tentacles are undeveloped in young medusae. In $S$. bedoti, medusae have scattered exumbrellar nematocysts, the manubrium is less distinctly cruciform in cross-section than in L. agassizii, and the four marginal tentacles are equally developed at all stages of growth.

Adult medusae of Sphaerocoryne peterseni Bouillon, 1984a, have adaxial patteries of nematocysts along each of four marginal tentacles, and an abaxial ocellus is present on each tentacle bulb. The hydroid stage of this species is unknown.

\section{Sphaerocoryne bedoti Pictet, 1893}

Figs. 46,47

Sphaerocoryne bedoti Pictet, 1893:10; pl. 1, figs. 5,6. Clavatella multitentaculata Warren, 1908:278; pl. 45, figs. 7-9.

Sphaerocoryne multitentaculata-Stechow, 1921a:248.

Eleutheria multitentaculata-Bedot, 1925:179.

Sphaerocoryne sp.-Gravely, 1927:8; pl. 2, fig. 3.

Coryne (?) multitentaculata-Pennycuik, 1959:158.

\section{TYPE LOCALITY}

Ambon, Moluccas, Indonesia.

\section{MATERIAL EXAMINED}

Major's Bay, Harrington Sound, on sponge, $-2 \mathrm{~m}, 13$ September 1977, several hydranths with medusa buds, and several newly liberated medusae, ROMIz B132. Major's Bay, Harrington Sound, on sponge, $-2 \mathrm{~m}, 13$ September 1977, several hydranths with medusa buds, ROMIz B 177 . Walsingham Pond area, cave entrance, on underside of rock, $-1 \mathrm{~m}, 29$ June 1983, two hydranths, $1 \mathrm{~cm}$ high, without gonophores, ROMIZ B331.

\section{DESCRIPTION}

Hydrorhiza embedded in sponge. Hydrocaulus monosiphonic, unbranched, about $1 \mathrm{~cm}$ high, $120 \mu \mathrm{m}$ wide, supporting a terminal hydranth. Perisare rather thin, hyaline, smooth or with a few wrinkles; distinct annulations not apparent. Hydranths pyriform, $0.8 \mathrm{~mm}$ high, $0.5 \mathrm{~mm}$ wide, with an elongate hypostome. Tentacles eapitate, of varying length, about 30 in number, seattered in a narrow band around bulbous hydranth base.

Nematocysts-

Hydroids: desmonemes $12.4-13.2 \mu \mathrm{m} \times 5.6-5.9 \mu \mathrm{m}$; stenoteles (small) $11.2-12.2 \mu \mathrm{m} \times 7.7-9.2 \mu \mathrm{m}$; stenoteles (large) $24.4-26.3 \mu \mathrm{m} \times 16.8-18.0 \mu \mathrm{m}$.
Gonophores developing in small clusters, borne on hydranth just distal to tentacles. Well-developed medusa buds and newly liberated medusae thimble-shaped, $450 \mu \mathrm{m}$ high, $350 \mu \mathrm{m}$ wide in alcohol-preserved specimens: exumbrella with scattered nematocysts; mesoglea thin; manubrium simple, conical, reaching about halfway to velar opening. Radial canals four. Tentacle bulbs four, equally developed; marginal tentacles scarcely if at all developed. Ocelli and gonads undeveloped.

Nematocysts-

Medusae: desmonemes 8.3-9.5 $\mu \mathrm{m} \times 3.8-4.5 \mu \mathrm{m}$; basitrichous haplonemes $9.2-10.8 \mu \mathrm{m} \times 7.9-9.4 \mu \mathrm{m}$; stenoteles (small) 9.1-9.7 $\mu \mathrm{m} \times 6.5-7.5 \mu \mathrm{m}$; stenoteles (large) $12.4-13.6 \mu \mathrm{m} \times 8.8-10.5 \mu \mathrm{m}$.

\section{REMARKS}

Three nominal species of the genus Sphaerocoryne Pictet. 1893, S. bedoti Pictet. 1893, S. multitentaculata (Warren. 1908), and S. peterseni Bouillon, 1984a, have been described in the literature. Only the medusa stage of $S$. peterseni is known. Hydroids of the other two, found on sponges, are virtually inseparable based on currently available descriptions. Yamada and Konno (1973) preferred to
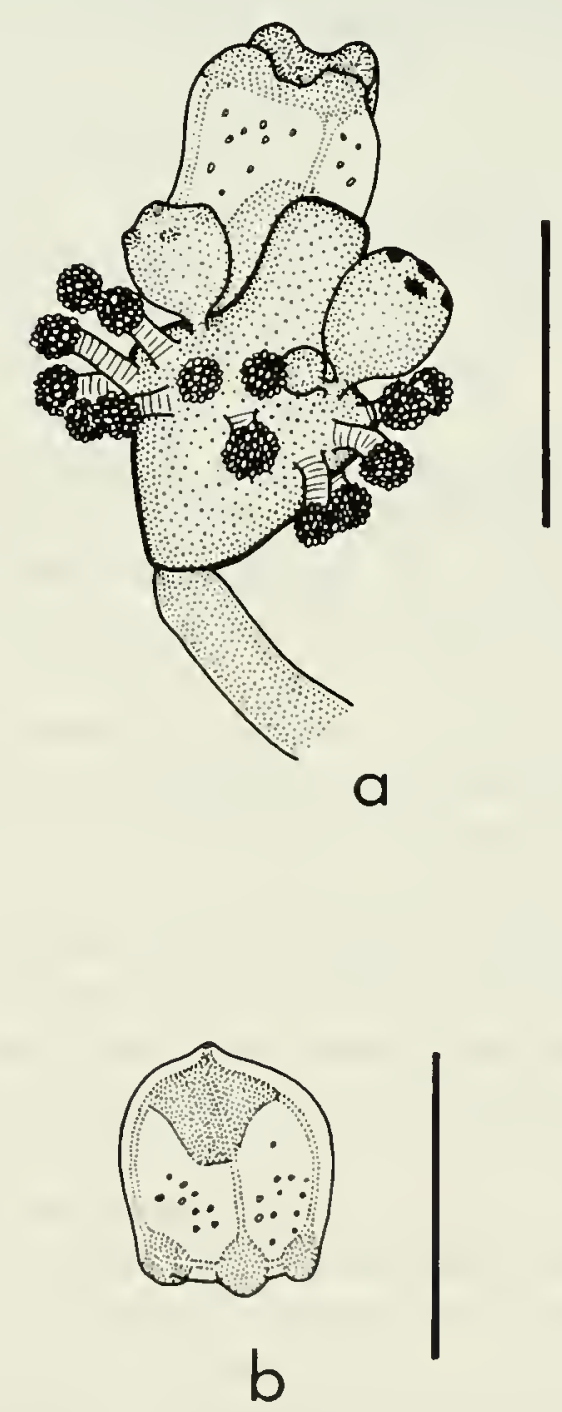

Fig. 46. Sphaeroconge bedoti. Scales equal $0.5 \mathrm{~mm}$. a, Part of hydrocaulus, and hydranth, ROMI\% B177. b. Newly liberated medusa, Roni\% 13132. 


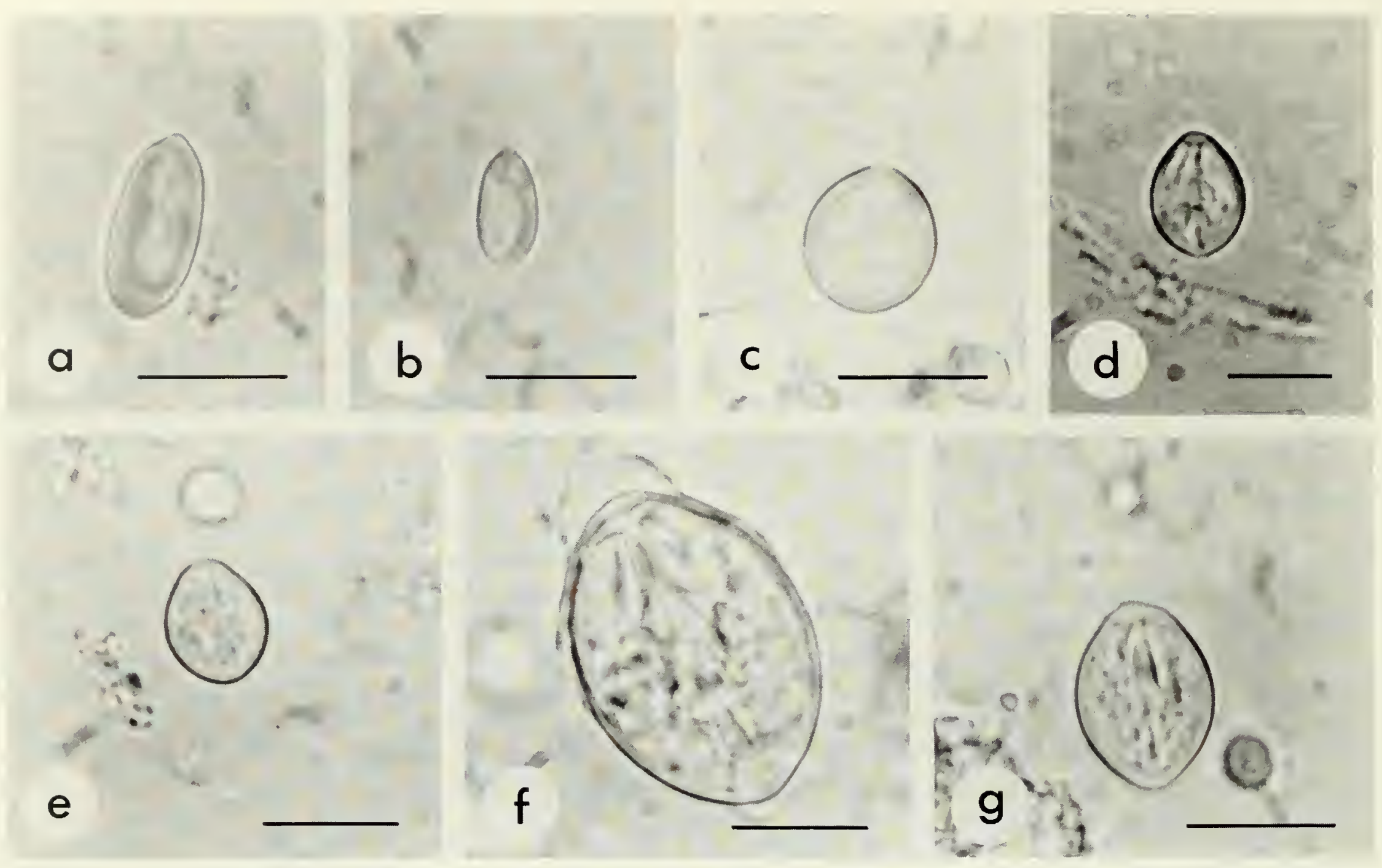

FIG. 47. Sphaerocoryne bedoti, nematocysts of hydranth and medusa bud. Scales equal $10 \mu \mathrm{m}$. $a$, Desmoneme of hydranth, ROMIz B331. b, Desmoneme of medusa bud, ROMlz B132. c, Basitrichous haploneme of medusa bud, ROMiz B132. $d$, Small stenotele of hydranth, romiz B331. e. Small stenotele of medusa bud, ROMIz B132. $f$, Large stenotele of hydranth, ROMIz B331. g, Large stenotele of medusa bud, ROMIz B 132 .

recognize $S$. multitentaculata as a valid species because of a general lack of information on living material from areas other than Japan, but Mammen (1963) and Millard (1975) have been followed here in regarding it as conspecific with $S$. bedoti.

Yamada and Konno (1973) described the hydroid of this species and outlined the development of the medusa from liberation to maturity. They found that the four marginal tentacles developed concurrently in the medusa, and that an abaxial ocellus appeared on each tentacle bulb about 8 to 10 days after liberation. Medusae raised on Artemia in the laboratory were mature two weeks after release from the hydroid. Male medusae were ovoid, 2.5-3.5 $\mathrm{mm}$ high, $2.0-3.0 \mathrm{~mm}$ wide, and possessed a manubrium two-thirds to four-fifths the length of the subumbrellar cavity. Female medusae were conical, $3.0-4.5 \mathrm{~mm}$ high, $2.0-3.0 \mathrm{~mm}$ wide, and bore a manubrium about two-thirds the length of the subumbrellar cavity. These laboratory-reared specimens have not been identified with any previously named species of medusa.

Bermudian hydroids of Sphaerocoryne bedoti tended to be slightly smaller than those described from Indonesia (Pictet, 1893), South Africa (Warren, 1908), India (Mammen, 1963), and Japan (Yamada and Konno, 1973). However, the range of hydranth size and shape in this species is reflected in both living and preserved material examined by Mammen (1963). Tentacle number is likely to vary somewhat with hydranth size, and tentacle arrangement appears to differ depending upon the degree of expansion or contraction of the hydranth. Newly liberated medusae of this species from Bermuda, measured after five years in preservative, were decidedly smaller than those described by Yamada and Konno (1973). Part of this difference may be attributable to contraction of my specimens on preservation, and their subsequent shrinkage in the alcohol preservative.

\section{KNOWN RANGE}

Bermuda: inshore, on sponges (Calder, 1986). Elsewhere: western Atlantic (Mergner and Wedler, 1977); Indian Ocean (Millard and Bouillon, 1974); western Pacific (Yamada and Konno, 1973). 
Corynidae Johnston, 1836:107.

Sarsiadae Forbes, 1848:54.

Syncorynidae Allman, 1872:274.

Codonidae Haeckel, 1879:9.

\section{DIAGNOSIS}

Hydroid colonies stolonal or erect, with creeping hydrorhiza and upright, unbranched or irregularly branched hydrocaulus. Perisarc firm. Hydranths variable in shape but often clavate, with an oral whorl of capitate tentacles, frequently with scattered or verticillate capitate tentacles extending proximally over hydranth, and with or without an aboral whorl of reduced filiform tentacles. Hypostome dome-shaped to conical.

Gonophores fixed sporosacs or free medusae, borne on hydranth proximal to or among capitate tentacles. Medusae, when present, bell-shaped, without exumbrellar nematocyst tracks; manubrium tubular, short and enclosed within subumbrellar cavity or long and extending beyond velar opening; mouth simple, circular. Radial canals four. Marginal tentacles four. Ocelli present. Gonads surrounding manubrium, arranged in one or more rings.

\section{REMARKS}

The scope of the family Corynidae Johnston, 1836, adopted here encompasses only the genera Coryne Gaertner, 1774, Sarsia Lesson, 1843, and Dipurena McCrady, 1859a. The poorly known genus Dicodonium Haeckel, 1879, has generally been regarded as a corynid, but apparently is not (Brinckmann-Voss, 1970). Accordingly, the name of the tribe Dicodoniini, established for this genus by Cockerell (1911), is excluded from the synonymy of the Corynidae given above. Petersen (1979) has been followed in referring Sphaerocoryne Pictet, 1893, and Linvillea Mayer, 1910, to the Sphaerocorynidae Prévot, 1959, as well as Dicyclocoryne Annandale, 1915, and Bicorona Millard, 1966, to the Dicyclocorynidae Petersen, 1979. Earlier, Rees (1957) removed Hydrocoryne Stechow, 1907, to a new family, the Hydrocorynidae. Among other nominal genera frequently encountered in discussions of corynids, Syncoryna Ehrenberg, 1834, and Staurocoryne Rotch, 1872 , are regarded as congeneric with Coryne (e.g., see Millard, 1975), and Stauridiosarsia Mayer, 1910, is considered to be congeneric with Sarsia (e.g., see Brinckmann-Voss, 1970; Millard, 1975; Arai and Brinckmann-Voss, 1980; Bouillon, 1985). The systematic affinities of Sarsiella Hartlaub, 1907, and Bibrachium Stechow, 1919, are unclear, although both were included in the Corynidae by Bouillon (1985). The family-group name Codonidae Haeckel, 1879 (correctly spelled Codoniidae) is included as a synonym of the name Corynidae because its type genus,
Codonilum Haeckel, 1879, is congeneric with Sarsia (Mayer, 1910).

The corynid genera Coryne, Sarsia, and Dipurena were recently redefined by Petersen (1979). In his classification, tentacle arrangement and gonophore location on the hydranth of the hydroid, as well as manubrium length, extent of the manubrium functioning as a "stomach," and position of the gonad on the manubrium in the medusa, were used to distinguish genera. It is possible, following Petersen's diagnoses, to refer corynid hydroids to genus in the absence of information on type of gonophore produced. It remains to be determined whether this classification is more "natural" than the one adopted by most other current authors.

The filiform tentacles of corynid hydroids, which may be present or absent even within a given species, were regarded as evolutionary vestiges by Rees (1957). Edwards and Harvey (1983) disputed this, suggesting instead that they are highly specialized sense organs used for detection of prey as indicated by Tardent and Stössel (1971), Stössel and Tardent (1971), and Tardent and Schmid (1972).

\section{Genus Coryne Gaertner, 1774}

Coryne Gaertner, 1774:40.

Fistularia O. F. Müller, 1776a:254 [invalid junior homonym of Fistularia Linnaeus, 1758 (Pisces)].

Fistulana O. F. Müller, 1776a:282.

Capsularia Modeer, 1793:256 [nomen nudum].

Capsularia Cuvier, 1798:665.

Corine Cuvier, 1798:656 [incorrect subsequent spelling]. Coryna Bosc, 1802:238 [incorrect subsequent spelling].

Corina Schweigger, 1820:409 [incorrect subsequent spelling].

Stipula M. Sars, 1829:4.

Syncoryna Ehrenberg, 1834:294.

Hermia Johnston, 1838:111.

Syncoryne Steenstrup, 1842:10 [incorrect subsequent spelling].

Halybotrys de Filippi, 1866:383.

?Actinogonium Allman, 1871:95 [invalid junior homonym of Actinogonium Schomburgk, 1847 (?Protozoa)].

Syncorine Spagnolini, 1871:211 |incorrect subsequent spelling].

Staurocoryne Rotch, 1872:126.

Halobotrys Carus, 1885:2 [incorrect subsequent spelling|.

Eucoryne Broch, 1909:138 [invalid junior homonym of

Eucoryne Leidy, 1855 (Hydrozoa)].

Halybothrys Bedot, 1910:310 [incorrect subsequent spellingl.

?Actigia Stechow, 1921a:248 
DIAGNOSIS

Corynid hydroids with stolonal or erect and branching colonies. Hydranths with several more or less distinct whorls of capitate tentacles distally, those of one whorl often alternating with those of adjacent whorls; hydranths occasionally with a whorl of reduced filiform tentacles proximally.

Gonophores fixed sporosacs, arising on hydranth either in axils of capitate tentacles or just proximal to capitate tentacles.

\section{TYPE SPECIES}

Corvne pusilla Gaertner, 1774, by monotypy.

\section{REMARKS}

The diagnosis of Coryne Gaertner, 1774, given above is similar to that adopted by Brinckmann-Voss (1970), Millard (1975), Bouillon (1985), and others. It diflers from the definition of the genus proposed by Petersen (1979), who included in Corvne those species of corynids having a stolonal or erect and branching colony form; capitate tentacles alternating in successive whorls; filiform tentacles either present or absent; gonophores arising either in the axils of the tentacles or in a whorl replacing the lowest verticil of capitate tentacles; and medusae, when present, with a short manubrium completely or almost completely surrounded by the gonad. Although not followed in this report, Petersen's ideas concerning the scope of the genus merit further evaluation.

The name of this genus was originally spelled Coryne by Gaertner (1774); Corine Cuvier, 1798, Coryna Bosc, 1802, and Corina Schweigger, 1820, are incorrect subsequent spellings. Broch (1909) founded the subgenus Eucoryne within the genus, but that name is an invalid junior homonym of Eucoryne Leidy, 1855.

Although the name Fistularia had been applied to a genus of fishes by Linnaeus (1758), O. F. Müller (1776a) applied the same name to a genus of hydroids. Later in the same publication, Müller employed the name Fistulana as a replacement name for Fistularia O. F. Müller, 1776a. One of the hydroids included in Fistulana by Müller was Tubularia ramosa Linnaeus, 1758, the type species of Eudendrium Ehrenberg, 1834. Had this species been designated type species of Müller's nominal genus, the virtually forgotten name Fistulana would be a senior objective synonym of the widely used name Eudendrium. To my knowledge, no type species has ever been designated for Fistulana. Accordingly, Tubularia muscoides Linnaeus, 1761, another species included by Müller (1776a) in his genus but now included in Coryne, is hereby designated as type species of Fistulana. The name Fistulana thus becomes a junior subjective synonym of Coryne, and its potential nomenclatural threat to Eudendrium is removed.

Van Beneden (1844b) identified as Syncoryna pusilla
Gaertner, 1774, a hydroid that was subsequently shown by Hincks (1868) and Allman (1872) to be a different species. Hincks (1868) proposed the name Coryne vanbenedenii for this hydroid. Allman (1871, 1872) removed it to a new nominal genus, Actinogonium, chiefly because an actinula larva was reported in its life cycle, and he renamed the species $A$. pusillum. Stechow (1921a) noted that Actinogonium Allman, 1871, is a junior homonym of Actinogonium Schomburgk, 1847, a protozoan, and proposed Actigia as a replacement name. Brinckmann-Voss (1970) listed the species from the Mediterranean, based on a questionable record by Schneider (1898a), under the genus Coryne.

Stechow (1923a) has been followed in regarding Stipula M. Sars, 1829, Syncoryna Ehrenberg, 1834, Hermia Johnston, 1838, and Halybotrys de Filippi, 1866, along with Fistularia O. F. Müller, 1776a, Fistulana, Capsularia Cuvier, 1798, and Eucoryne Broch, 1909, as congeneric with Coryne. Stechow also regarded Acrochordium Meyen, 1834, as a synonym of Corvne, but it belongs in the Zancleidae Russell, 1953 (see p. 69). Staurocoryne Rotch, 1872, has been regarded as congeneric with Coryne, following Millard (1975), Edwards and Harvey (1983), and Bouillon (1985). Under the definition of this genus proposed by Petersen (1979), Stauridia Wright, 1858b [not Stauridia Forbes, 1848], Stanidiosarsia Mayer, 1910, and Perinema Stechow, 1921c, would be congeneric with Coryne. They are regarded here as congeneric with Sarsia Lesson, 1843.

\section{Coryne sargassicola, sp. nov.}

Figs. 48, 49

Syncoryne mirabilis--Fraser, 1912:347; fig. 3 [not Sarsia mirabilis L. Agassiz, 1849 (= Sarsia tubulosa (M. Sars, 1835))].

Syncoryne sp. Burkenroad in Parr, 1939:23.

Syncoryne (Sarsia) mirabilis-Morris and Mogelberg, 1973: 10; fig. 2.

\section{MATERIAL EXAMINED}

Holotype: Natural Arches Beach, washed ashore on pelagic Sargassum. 8 March 1982, one colony, $2.7 \mathrm{~mm}$ high, without gonophores, Romiz B 159. Paratypes: Whalebone Bay, on pelagic Sargassum, 6 September 1977, one colony, $2.7 \mathrm{~mm}$ high, without gonophores, Romiz B156; Natural Arches Beach, washed ashore on pelagic Sargassum. 8 March 1982, one colony, $2.5 \mathrm{~mm}$ high, without gonophores, ROMIz B302; Gulf Stream, east-southeast New York City, $40^{\circ} 02^{\prime} \mathrm{N}, 70^{\circ} 50^{\prime} \mathrm{W}$, on pelagic Sargassum, I October 1969, one colony, $4.5 \mathrm{~mm}$ high, with gonophores, coll. M. Fine on R/V Eastward, Romiz B490. 
Fig. 48. Cornne sargassicola, sp. nov., part of colony with hydrorhiza, hydrocaulus, and hydranth, ROMl B302. Scalc equals $0.5 \mathrm{~mm}$.
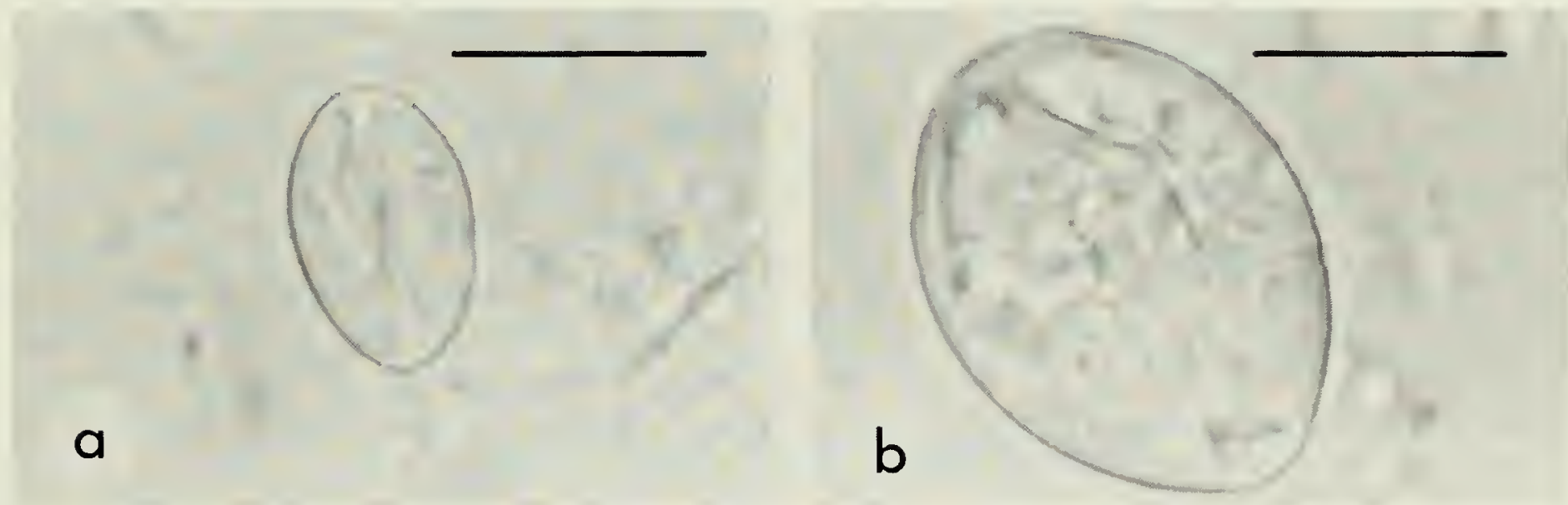

FIG. 49. Coryne sargassicola, sp. nov., nematocysts of hydranth, Romiz B302. Scale equals $10 \mu \mathrm{m} . a$, Small stenotele. $b$, Large stenotele.

\section{DESCRIPTION}

Hydroid colonies typically stolonal, occasionally with an irregular branch; pedicels arising from a creeping hydrorhiza. Pedicels up to $3 \mathrm{~mm}$ long, $0.12 \mathrm{~mm}$ wide, supporting terminal hydranth. Perisarc of moderate thickness basally, thinning out distally, smooth or with a few wrinkles but not annulated, terminating below tentacles on hydranth. Hydranth elongate-oval, reaching $1 \mathrm{~mm}$ long, $0.3 \mathrm{~mm}$ wide; tentacles arranged in whorls of four to six each, with those of one whorl alternating with those of adjacent whorls; oral tentacles capitate, with terminal knobs 65-85 $\mu \mathrm{m}$ in diameter; aboral tentacles capitate, in one to four whorls, with terminal knobs of lowest whorl 55$60 \mu \mathrm{m}$ in diameter; basal whorl of reduced filiform tentacles present or absent. Hypostome conical, moderately clongate.

Nematocysts-

Hydroids: stenoteles (small) 11.7-12.2 $\mathrm{m} \times 6.7-$ $7.3 \mu \mathrm{m}$; stenoteles (large) 19.9-20.8 $\mathrm{m} \times 14.1-15.1 \mu \mathrm{m}$.

Gonophores presumably fixed sporosacs, arising from hydranth in axils of proximal tentacles.

\section{REMARKS}

This species has been referred to Coryne Gaertner, 1774, rather than to Sarsia Lesson, 1843, or Dipurena McCrady, 1859a, because gonophores in paratype material (ROMIZ B490) appear to be fixed sporosacs arising from the axils of the tentacles. It also corresponds with the genus Coryne as defined by Petersen (1979).

Coryne sargassicola, sp. nov., is regarded as conspecific with the corynids reported earlier from Sargassum by Fraser (1912) and Morris and Mogelberg (1973) as Syncoryne mirabilis (L. Agassiz, 1849), and by Burkenroad in Parr (1939) as Syncoryne sp. Following Kramp (1928), $S$. mirabilis is now generally regarded as a synonym of Sarsia tubulosa (M. Sars, 1835). It is improbable that the boreal $S$. tubulosa ranges into the warm waters where pelagic Sargassum is normally found, and where the present species occurs.

Hydroids of Sarsia tubulosa and Coryne sargassicola are similar in colony form and in having smooth perisarc. However, filiform tentacles, observed on some hydranths of C. sargassicola (ROMIZ B 156, ROMIZ B302), are lacking in $S$. tubulosa (e.g., see Edwards, 1978, 1983; BrinckmannVoss, 1985). Moreover, the hydroid of $S$. mbulosa produces free medusae instead of fixed sporosacs. It is unclear whether Fraser (1912) actually observed liberation of gonophores in the hydroid he identified as Sincorve mirabilis, or whether he simply assumed they would be released. 
He noted that the "medusae" of his specimens were sexually mature before liberation.

L. Agassiz (1849), Mayer (1910), and Berrill (1953) reported that free medusae were produced by hydroids of Sarsia tubulosa at certain times of year, and fixed eumedusoids at other times. Edwards (1978) found no such variation in gonophore type in cultures of $S$. tubulosa maintained in the laboratory. Hydroids of that species cultured at various temperatures by Edwards all released their medusae, and none of the medusae bore gonads at liberation. Likewise, Edwards demonstrated that temperature variation had no influence on the type of gonophore produced by either Sarsia occulta Edwards, 1978, or Sarsia lovenii (M. Sars, 1846). In the former species, gonads were partially developed in the medusa prior to its liberation. In $S$. lovenii, gonophores ripened on the hydranth and were not released as free medusae. Edwards concluded that $L$. Agassiz, Mayer, and Berrill had confused more than one valid taxon for a single species.

Hydroids of Coryne sargassicola resemble those of $C$. pinmeri Schneider, 1898a, and of C. filiformis (Rees, 1936), but are smaller and lack annulations on the perisarc. They also resemble the cold-water $C$. hincksii Bonnevie, 1898 , but dimensions of the latter given by Rees (1956b) and Calder (1972) indicate that it is a more robust species than C. sargassicola.

Observations on live material are needed to clarify the life cycle of this hydrozoan, and to confirm its generic identity.

\section{ETYMOLOGY}

The specific name is derived from a combination of the generic name Sargassum plus the Latin suffix cola, a dweller, in reference to the algal substrate of this species.

\section{KNOWN RANGE}

Bermuda: on pelagic Sargassum (Burkenroad in Parr, 1939. as Syncoryne sp.).

Elsewhere: western Atlantic (Fraser, 1912, as Syncoryne mirabilis).

\section{Family Cladonematidae Gegenbaur, 1857}

Cladonemiden Gegenbaur, 1857:220 lemended to Cladonematidae by Poche, 1914:70].

Stauridiidae Hincks, 1868:61.

Dendronemidae Haeckel, 1879: 107.

\section{DIAGNOSIS}

Hydroid colonies with creeping stolons and short, unbranched or sparingly branched hydrocauli with terminal hydranths. Perisarc of moderate thickness, terminating at hydranth base. Hydranths clavate, with an oral whorl of capitate tentacles, usually with an aboral whorl of reduced filiform tentacles.

Gonophores free medusae, arising from hydranth just distal to filiform tentacles: medusae creeping or swimming. Manubrium with radial pouches; these pouches short and enclosed within subumbrellar cavity or moderately long and extending beyond velar opening; mouth with oral tentacles bearing nematocyst clusters. Radial canals bifurcated or simple, number variable. Marginal tentacles hollow, equal in number to radial canals, branching, bearing organs of adhesion. Ocelli present. Gonads surrounding manubrium.

\section{REMARKS}

Prévot (1959), Naumov (1960), and Millard (1975) believed that differences between the Cladonematidae Gegenbaur, 1857, and the Eleutheriidae Stechow, 1923a, were insufficient to warrant recognition of both families. Although the two families are acknowledged here to be closely related, the Eleutheriidae are regarded as distinct from the Cladonematidae largely on the basis of differences in the medusa. These differences include the presence of a nematocyst ring around the umbrella margin, the lack of oral tentacles, the location of the gonads, and the reduced umbrella in the Eleutheriidae.

Hydroids of this family resemble those of the Corynidae Johnston, 1836. Their medusae share with those of the Corynidae characters such as the presence of ocelli and the location of the gonad in a ring around the manubrium, but are otherwise rather highly specialized.

\section{Genus Cladonema Dujardin, 1843a}

stauridie Dujardin, 1843a:1133.

Cladonema Dujardin, 1843a:1134.

Stauridia Forbes, 1848:81 [emendation of stauridie Dujardin, 1843a].

Stauridium Krohn, 1853a:137 [emendation of stauridie Dujardin, 1843a].

Stauridia Wright, 1858b:284 [invalid junior homonym of Stauridia Forbes, 1848 (Hydrozoa)].

\section{DIAGNOSIS}

With the characters of the family.

\section{TYPE SPECIES}

Cladonema radiatum Dujardin, 1843a, by monotypy. 


\section{REMARKS}

The genus Cladonema and its type species, C. radiatum, were described in two separate but essentially identical papers by Dujardin (1843a, 1843b). One of these papers (Dujardin, 1843a) appeared in the January-June issue of the Comptes Rendus Hebdomadaires des Séances de l'Académie des Sciences. The other (Dujardin, 1843b) was published in the December issue of the Annales des Sciences Naturelles. Accordingly, the former is taken as the first publication of the generic name Cladonema and of its type species, $C$. radiatum.

The name "stauridie," applied by Dujardin (1843a, $1843 \mathrm{~b}$ ) to the hydroid of the medusa Cladonema radiatum, is not available [Art. 11]. The name of Dujardin's (1843a, 1843b) hydroid, stauridie, was emended to Stauridia by Forbes (1848). Wright (1858b), apparently unaware that Forbes had emended the name, also proposed the name Stauridia for this hydroid genus and included a new species, $S$. producta, in it. However, $S$. producta produces medusae referable to the family Corynidae Johnston, 1836 , as first shown by Hincks (1862), and is not congeneric with the hydroid described by Dujardin (1843a, 1843b). Mayer (1910) removed S. producta to a new genus, Stauridiosarsia, a name considered synonymous with Sarsia Lesson, 1843.

Dendronema Haeckel, 1879, is similar to Cladonema, but was recognized as a valid genus by Bouillon (1985).

\section{Cladonema radiatum Dujardin, 1843a}

Fig. 50

stauridie Dujardin, 1843a:1133.

Cladonema radiatum Dujardin, 1843a:1134 [medusa].

Coryne stauridia Gosse, 1853:260.

Coryne stauridiai Gosse, 1853, pl. 16, figs. 1-5 [lapsus].

Syncoryne stauridium Krohn, 1853a:420.

Cladonema radiatum gegenbauri Haeckel, 1879:109 [medusa].

Cladonema radiatum krohnii Haeckel, 1879:109 [medusa].

Cladonema radiatum dujardinii Haeckel, 1879:109 [medusa].

Cladonema radiatum allmani Haeckel, 1879:109 [medusa].

Stauridium cladonema Haeckel, 1879:109.

Cladonema sp. Fewkes, 1883:87 [medusa].

Cladonema sp. Perkins, 1902:25 [medusa].

Cladonema radiata-Johansen and Levinsen, 1903:278 [medusa].

Cladonema perkinsii Maycr, 1904:18; pl. 4, fig. 35 [medusa].

Cladonema mayeri Perkins, 1906: 118 [medusa and hydroid].

Cladonema allmani-Perkins, 1908:138 [medusa].

Cladonema dujardinii-Perkins, 1908: 138 [medusa].

Cladonema gegenbauri-Perkins, 1908:140 [medusa].

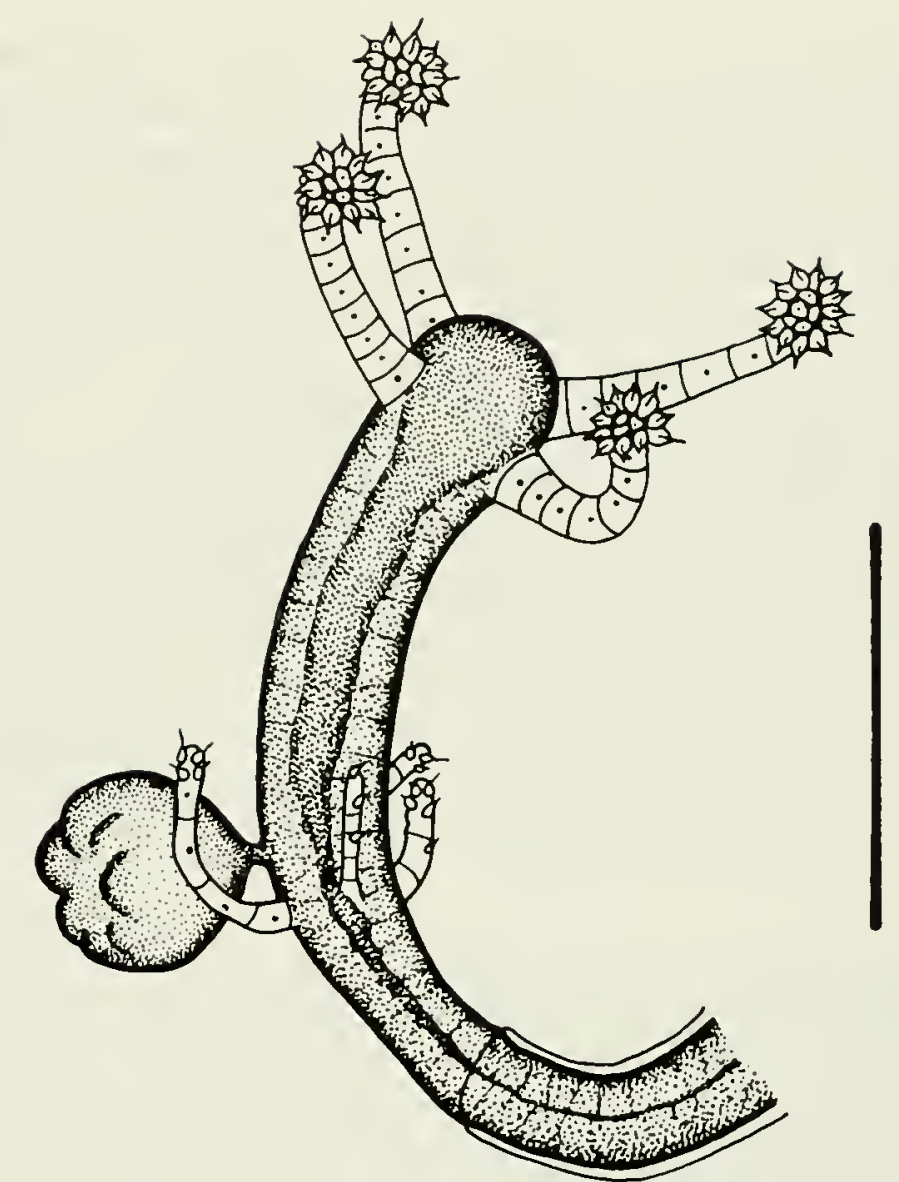

FIG. 50. Cladonema radiatum, part of hydrocaulus, and hydranth with medusa bud, ROMIz B 144. Scale equals $0.25 \mathrm{~mm}$.

Cladonema krohnii-Perkins, 1908:140 [medusa].

Stauridia radiatum-Mayer, 1910:100.

Eleutheria radiata - Lengerich, 1922:210; fig. 1 [medusa]

Eleutheria perkinsii-Lengerich, 1922:211 [medusa].

not Cladonema radiatum var. mayeri Uchida, 1925:81: fig. 7 [ = Cladonema uchidai Hirai, 1958].

Cladonema dujardini-Bedot, 1925:486 [medusa] [incorrect subsequent spelling].

Cladonema perkinsi-Bedot, 1925:486 [medusa] [incorrect subsequent spelling].

\section{TYPE LOCALITY}

Mediterranean Sea.

\section{MATERIAL EXAMINED}

Ferry Reach, St George's Island, opposite Whalebone Bay, on Thalassia, $-1.5 \mathrm{~m}, 26$ July 1982, two hydranths, with medusa buds, RomIz B 144; medusa, newly liberated, obtained in laboratory from one of the hydranths above, Romiz B151. Whalebone Bay, on Thalassia, $-2 \mathrm{~m}, 8$ September 1977, one hydranth, ROMIz B 157.

\section{DESCRIPTION}

Hydroid colonies with unbranched pedicels arising from a creeping hydrorhiza. Pedicels up to $4 \mathrm{~mm}$ long but usually much shorter, $75 \mu \mathrm{m}$ wide, supporting a terminal hydranth. Perisare smooth, of moderate thickness, terminating a short distance below filiform tentacles on hydranth. Hydranths clavate, reaching $638 \mu \mathrm{m}$ long, $128 \mu \mathrm{m}$ 
wide, with an oral whorl of four capitate tentacles and an aboral whorl of four filiform tentacles. Capitate tentacles solid, $326 \mu \mathrm{m}$ long, $47 \mu \mathrm{m}$ wide at base, tapering distally, with seven to nine endodermal cells: terminal knobs about $75 \mu \mathrm{m}$ wide, button-shaped. Filiform tentacles solid, I $68 \mu \mathrm{m}$ long, $33 \mu \mathrm{m}$ wide, with four to six endodermal cells, alternating with capitate tentacles. Hypostome rounded, with an oral, ectodermal cavity.

Medusa buds developing on short stalks just distal to filiform tentacles. Newly liberated medusa dome-shaped, $319 \mu \mathrm{m}$ high and $426 \mu \mathrm{m}$ wide in contracted, formalinpreserved specimen; mesoglea thin; manubrium short, wide, nearly spherical in longitudinal section. Radial canals nine. Tentacle bulbs nine, each with a single, reddish abaxial ocellus. Marginal tentacles nine, each with an adhesive organ and several bulbous clusters of nematocysts.

\section{REMARKS}

Hydroids of the various nominal species of Cladonema Dujardin, 1843a, are similar morphologically. Those of C. myersi Rees, 1949, and C. uchidai Hirai, 1958, apparently both lack the whorl of filiform tentacles found in other species of the genus (Rees, 1949; Hirai, 1958; Naumov, 1960), and Rees (1979) suggested that the two might be conspecific. Cladonema radiatum Dujardin, 1843a, and C. californicum Hyman, 1947, each possess both capitate and filiform tentacles and are virtually inseparable from one another in existing descriptions. However, Rees (1979), who first described the hydroid of $C$. californicum, did not include macrobasic mastigophores as part of the cnidome of this species. Nematocysts of this category have been reported from $C$. radiatum by Brinckmann and Petersen (1960), although they are not always present (Bouillon, 1971). Bouillon observed that when macrobasic mastigophores are present in C. radiatum, they occur principally in the stolons, rarely in the body of the hydranth, and never on the tentacles.

Hydroids of Cladonema radiatum also resemble those of Dipurena reesi Vannucci, 1956, and D. strangulata McCrady, 1859a. Brinckmann and Petersen (1960) found that $C$. radiatum differed from $D$. reesi in several respects, including the shape of the knobs and number of endodermal cells in the capitate tentacles, the presence of a slight terminal swelling on the filiform tentacles, the position of these tentacles on the hydranth, the shape of the stenoteles, and the presence of macrobasic mastigophores in addition to stenoteles. Calder (1970) reported that $D$. strangulata resembled $C$. radiatum in a number of these characters, such as the location of the filiform tentacles and the number of endodermal cells in the capitate tentacles, but differed in lacking the slight terminal swelling of the filiform tentacles. Macrobasic mastigophores were also lacking in $D$. strangulata. Bouillon (1971) found that the three species were distinguishable by the structure of the hypostome. Ectodermal gland cells in the hypostome form a dome in $D$. strangulata and several related species; a button in $D$. reesi; and a cavity in Cladonema as well as species of Staurocladia Hartlaub, 1918, and Eleutheria de Quatrefages, 1842.

Weill (1936) found medusae of Cladonema radiatum in Bermuda, and examined their nematocyst complement. Later, Weill (1937b) published observations on 106 specimens collected near the Bermuda Biological Station. These medusae encompassed the characteristics of $C$. radiatum, C. perkinsii, and C. mayeri. Weill concluded that the three nominal species were no more than varieties of one rather variable species, as Mayer (1910) had suggested earlier.

In Bermuda, the hydroid of Cladonema radiatum was observed only during the warmer months of the year.

\section{KNOWN RANGE}

Bermuda: no specific locality given (Weill, 1936); near the Bermuda Biological Station (Weill, 1937b); on Thalassia (Calder, 1986).

Elsewhere: western Atlantic (Mayer, 1910); eastern Atlantic (Brinckmann-Voss, 1970). In his monographs on medusae, Kramp $(1961,1968)$ regarded Cladonema uchidai as conspecific with $C$. radiatum. If this interpretation is correct, the known range of $C$. radiatum extends to the northwestern Pacific Ocean.

\section{Family Zancleidae Russell, 1953}

Zancleidae Russell, 1953:98.

\section{DIAGNOSIS}

Hydrorhiza creeping, with or without perisarc. Hydranths with tentacles scattered. Tentacles capitate, or virtually filiform, or of both types.

Gonophores free medusae, arising from hydranths. Medusa bell-shaped with a simple, circular mouth; exumbrella with or without oval or clavate patches or elongate tracks of specialized nematocyst-bearing tissue. Radial canals four. Marginal tentacles, when present, two or four, solid, each bearing abaxial cnidophores. Ocelli lacking. Gonads interradial, on manubrium.

\section{REMARKS}

Several names were proposed for this family before Russell (1953) established the Zancleidae, namely the Orthocorynidae by A. Agassiz (1865) and the Corynipteridae and 
Clavipteridae by Weill (1934). However, these latter three names do not meet the criteria of availability for familygroup names [Art. 11f (i)(1)], and do not take authorship and date $[$ Art. 10a]. If the nominal families Zancleidae and Pteronematidae Haeckel, 1879, are eventually shown to be identical, as believed by Picard $(1955,1957,1958)$ but disputed by Rees (1957), Bouillon (1974), and others. the latter name would have priority. Vervoort (1966:390) suggested that Pteronema darwinii Haeckel, 1879, might be "a mistreated and misjudged zancleid medusa," but he maintained the Zancleidae and Pteronematidae as separate families. Bouillon (1985) included the genus Pteronema Haeckel, 1879, in the family Asyncorynidae Kramp, 1949, rather than in the Zancleidae.

Bouillon (1974) broadened the definition of this family to include a new genus and species of hydroid and medusa, Teissiera milleporoides, from the Seychelles. Unlike other representatives of the Zancleidae, hydroids of $T$. milleporoides possess an encrusting skeleton instead of creeping stolons, and the polyps are polymorphic, with both gastrozooids and dactylozooids. The medusa generally resembles those of other genera within the Zancleidae except in having ocelli. Bouillon included four genera in this revised family, Zanclea Gegenbaur, 1857, Pteroclava Weill, 1931, Rosalinda Totton, 1949, and a new genus, Teissiera. Millard (1975) adopted this revised definition of the family. Later, Bouillon (1978c) erected a new family, the Teissieridae, to accommodate $T$. milleporoides and two new species of medusae referred to Teissiera, namely $T$. australe and $T$. medusifera. The definition of the Zancleidae was thus returned by Bouillon essentially to that outlined by Russell (1953) and Kramp (1959, 1961, 1968). Rosalinda, which shares many characteristics with Teissiera (Bouillon, 1974; Petersen, 1979), cannot be retained in the Zancleidae. Instead, the new family Rosalindidae was constituted for the genus by Bouillon (1985). As currently defined, the Zancleidae once again includes the genera Zanclea and Pteroclava, and possibly also Ctenaria Haeckel, 1879, and Oonautes Damas, 1936.

\section{Genus Zanclea Gegenbaur, 1857}

Acrochordium Meyen, 1834:165.

Mnestra Krohn, 1853b:281.

Zanclea Gegenbaur, 1857:229.

Gemmaria McCrady, 1859a:151.

Halocharis L. Agassiz, 1862:239.

Gymnocoryne Hincks, 1871:75.

Gemellaria Allman, 1871, pl. 7 [incorrect subsequent spelling].

Zanlcea Allman, 1872:290 [incorrect subsequent spelling]

Guentherella Weill, 1934:417.

Zanklea Riedl, 1963:126 [incorrect subsequent spelling].

\section{DIAGNOSIS}

Hydroid colonies stolonal, with perisarc covering hydrorhiza and hydrocaulus. Hydranth elongate. Tentacles capitate, scattered except for those in an oral whorl.

Gonophores free medusae, arising either from hydranth proximal to or among lower tentacles or, rarely, from hydrorhiza; hydranths with medusa buds occasionally reduced to blastostyles. Medusa bell-shaped, with exumbrellar nematocysts; mouth simple, circular. Radial canals four. Marginal tentacles, when present, numbering two or four, with abaxial cnidophores. Ocelli lacking. Gonads interradial.

\section{TYPE SPECIES}

Zanclea costata Gegenbaur, 1857, by monotypy.

\section{REMARKS}

The genus-group name Zanclea Gegenbaur, 1857, extensively used in the literature of both hydroids and medusae for more than a century (e.g., Hincks, 1868; Mayer, 1910; Fraser, 1944; Russell, 1953; Kramp, 1961; BrinckmannVoss, 1970; Millard, 1975; Petersen, 1979; Bouillon, 1985; Calder, 1986), is a junior synonym of the virtually forgotten name Acrochordium Meyen, 1834. In the influential works of L. Agassiz (1862), Bedot (1905), and Stechow (1923a), Acrochordiuın was mistakenly regarded as a junior synonym of Coryne Gaertner, 1774. A re-examination of Meyen's (1834) account of Acrochordium here indicates that it is congeneric with Zanclea rather than with Coryne.

Mnestra parasites Krohn, 1853b, and Zanclea costata Gegenbaur, 1857, type species of Mnestra Krohn, 1853b, and Zanclea respectively, are regarded as conspecific (Rees, 1953; Picard, 1957; Martin and Brinckmann, 1963). Thus, Zanclea is also a junior synonym of the infrequently used name Mnestra, a nominal genus with a single nominal species based on a parasitically deformed medusa (Ankel, 1952; Martin and Brinckmann, 1963). Picard (1957) remarked that he planned to submit an application to the ICZN, requesting that its plenary powers be used to suppress the name Mnestra in favour of Zanclea. To my knowledge, however, the application was never published in the Bulletin of Zoological Nomenclature.

In the interests of nomenclatural stability, the commission will be requested, in a future submission, to use its plenary powers to suppress the genus-group names Acrochordium and Mnestra for the Principle of Priority, and to place the name Zanclea on the Official List of Generic Names in Zoology.

Zanclea alba (Meyen, 1834), comb. nov. Figs. 51, 52

Acrochordium album Mcyen, 1834:165; pl. 28, fig. 8. Coryne sessilis Gosse, 1853:208; pl. 14, figs. 1-3. 
Mnestra parasites Krohn, 1853b:281 [parasitized medusa]. Tubularia implexa Alder, 1856b:439.

Zanclea costata Gegenbaur, 1857:229; pl. 8, fig. 4 [medusa]. Coryne pelagica Alder, 1857:103; pl. 7. figs. 1.2.

Zanclea gemmosa McCrady, 1859a:151; pl. 8, figs. 4.5 [medusa]

Coryne briareus Allman, 1859a:54.

Coryne implexa-Wright, 1859:107.

Coryne (margarica) implexa-Wright, 1859: 108.

Halocharis spiralis L. Agassiz, 1862:239; pl. 20, figs. $10,10 \mathrm{a}-\mathrm{c}$.

Zanclea implexa-Allman. 1864a:357 [medusa and hydroid].

Halocharis (Corynitis) spiralis-Alman, 1864a:358.

Corynitis agassizii-A. Agassiz, 1865:183 [part]. -Allman, 1872:287 [part]. —Bumpus, 1898:857. —Murbach, 1899:354; pl. 34, fig. 12. —Nutting, 1901:329; fig. 4. Hargitt, 1901a:307. - Hargitt, 1901b:584; fig. 48. - Hargitt, 1904b:42. [medusa] [not Corynitis agassizii McCrady, 1859a]

Gemmaria gemmosa-A. Agassiz, 1865:184; fig. 306 [medusa].

Gemmaria cladophora A. Agassiz, 1865:184; figs. 307310 [medusa].

Gymnocoryne coronata Hincks, 1871:76; pl. 5, figs. I, la. Gemellaria implexa-Allman, 1871, pl. 7, figs. 1-10 [incorrect subsequent spelling].

Gemmaria implexa-Allman, 1872:290.

Gemmaria sagittaria Haeckel, 1879:103:' pl. 7, figs. 3,4 [medusa].

Corynetis agassizii-Brooks, 1883a:136 [incorrect subsequent spelling] [not Corynitis agassizii McCrady, 1859a]. Zanclea inflexa-Pennington, 1885:51 [incorrect subsequent spelling].

Zanclea hargitti Hartlaub, 1907:119; fig. 109.

Zanclea sagittaria-Hartlaub, 1907:124.

Zanclea cladophora-Hartlaub, 1907:121; figs. 112, 113 [medusa].

Gemmaria sagittata-Hargitt, 1908:119 lincorrect subsequent spelling].

Gemmaria costata-Fraser, 1912:346, fig. 2.

Gemmaria implexa var. neapolitana Brückner, 1914:460; figs. 7-24.

Halocharis gemmosa-Stechow, 1923b:2.

Gemmaria sp. Timmermann, 1932:296.

Guentherella implexa-Weill, 1934:417.

Zanclea sessilis-Russell and Rees, 1936:124.

Mnestra implexa-Picard, 1958:188.

Zanklea costata-Riedl, 1963:126 [incorrect subsequent spelling].

\section{TYPE LOCALITY}

Atlantic Ocean, in the vicinity of the Azores, on Sargassum natans.

\section{MATERIAL, EXAMINED}

Atlantic Ocean, $2 \mathrm{~km}$ southeast of Castle Roads, on floating Sargassum, 24 July 1982, one colony, up to $3 \mathrm{~mm}$ high, with medusa buds, RomIz B145. Whalebone Bay, on floating Sargassum, 2 September 1977, one colony, up to $2 \mathrm{~mm}$ high, with medusa buds, ROMIz B 155 . Whalebone Bay, on floating Sargassum, 27 February 1982, one colony, up to $2 \mathrm{~mm}$ high, with medusa buds, RomIz B 168 . Natural Arches Beach, on stranded Sargassum, 8 March 1982, several colonies, up to $3 \mathrm{~mm}$ high, with medusa buds, ROMIz B170. St George's lsland, beach near Fort St Catherine's, on stranded Sargassum, 15 June 1983, several medusae, liberated in laboratory from hydroid, ROMIZ B332. Green Bay, Harrington Sound, on shell of Cerithium litteratum from Cladophora bed, $-2 \mathrm{~m}, 26$ September 1986, one colony, up to $2 \mathrm{~mm}$ high, without gonophores, ROMIZ B359.

\section{DESCRIPTION}

Hydroid colonies with creeping hydrorhiza and upright, unbranched pedicels. Pedicels up to $1.3 \mathrm{~mm}$ long, about $70 \mu \mathrm{m}$ wide basally, expanding distally, bearing a terminal hydranth. Perisarc of variable thickness, annulated at base of hydrocaulus, smooth distally, terminating at hydranth base. Hydranth nearly cylindrical, reaching $1.6 \mathrm{~mm}$ long, $150 \mu \mathrm{m}$ wide; hypostome dome-shaped. Tentacles as many as 40 or more, all capitate, scattered except for about 5 to 7 in an oral whorl, solid, with about six endodermal cells each, short and relatively stout in preserved material, about $75 \mu \mathrm{m}$ long, $50 \mu \mathrm{m}$ wide at base, tapering distally, terminating in a knob of nematocysts; knobs 35 $50 \mu \mathrm{m}$ wide, nearly spherical.

\section{Nematocysts-}

Hydroids: stenoteles (small) $6.7-7.0 \mu \mathrm{m} \times 4.9-5.3 \mu \mathrm{m}$; stenoteles (large) 9.6-10.4 $\mu \mathrm{m} \times 8.3-8.6 \mu \mathrm{m}$.

Medusa buds arising in clusters on short stalks among proximal tentacles on hydranth. Well-developed medusa buds bell-shaped, with thin mesoglea; exumbrella with nematocyst patches; manubrium short, conical to tubular. Radial canals four. Marginal bulbs four; opposite two well developed and bearing tentacles with cnidophores.

Nematocysts-

Medusae: macrobasic euryteles 6.4-7.1 $\mu \mathrm{m} \times 3.6-$ $4.4 \mu \mathrm{m}$; stenoteles 6.8-9.2 $\mu \mathrm{m} \times 5.8-7.5 \mu \mathrm{m}$.

\section{REMARKS}

These Sargassum-borne specimens are almost certainly identical with Acrochordium album Meyen, 1834, a small athecate hydroid found on "Fucus natans L." off the Azores. Meyen's (1834) hydroid, a stolonal species with numerous capitate tentacles scattered over an elongate hydranth, is not referable to Coryne Gaertner, 1774, as indicated in earlier literature (see p. 64). Instead, it conforms to the current concept of the genus Zanclea Gegenbaur, 


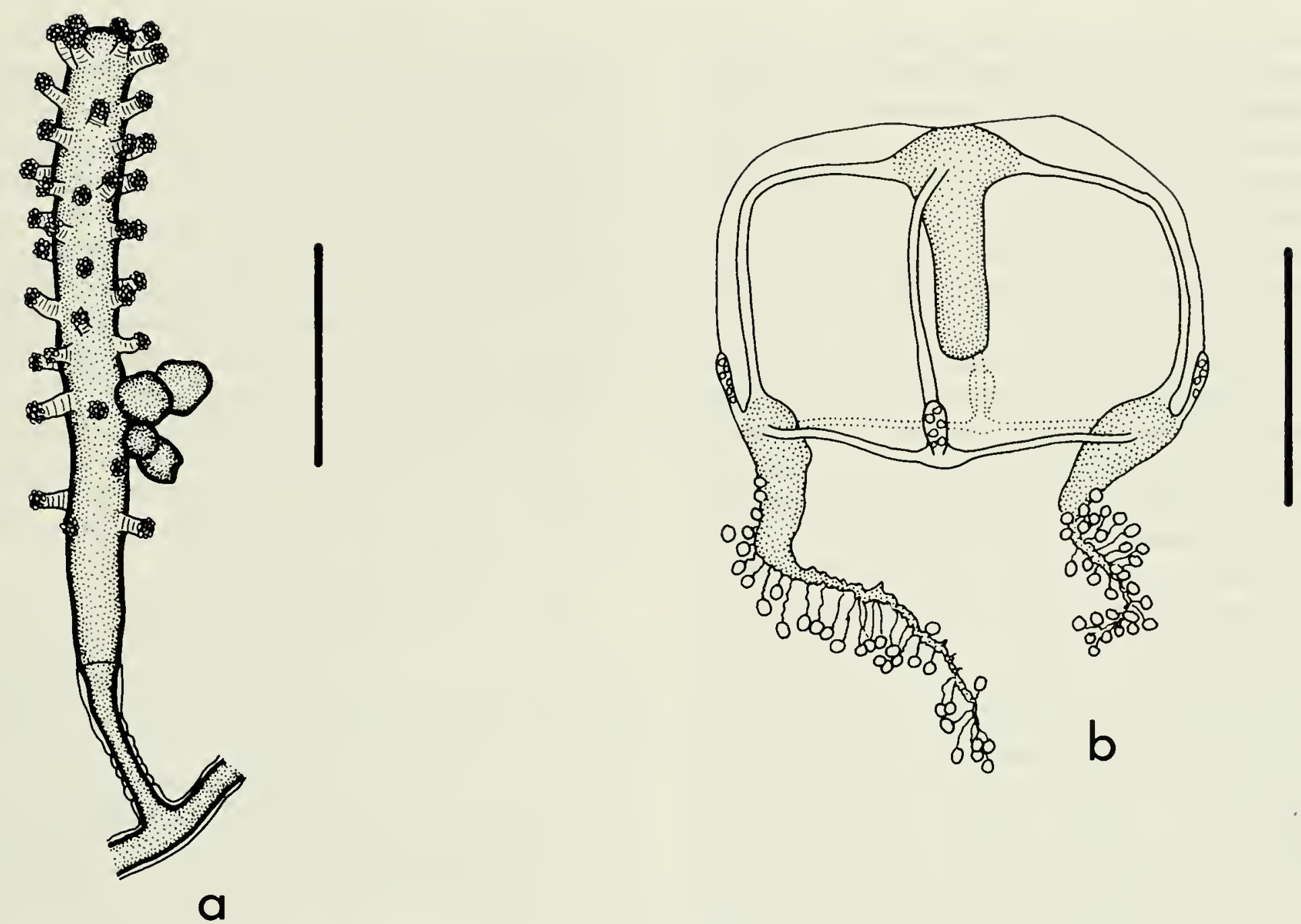

FIG. 51. Zanclea alba. Scale for $a$ equals $0.5 \mathrm{~mm}$; scale for $b$ equals $0.25 \mathrm{~mm}$. $a$, Part of colony with hydrorhiza, hydrocaulus, and hydranth, ROMIz B 145. b. Newly liberated medusa, romIz B332.

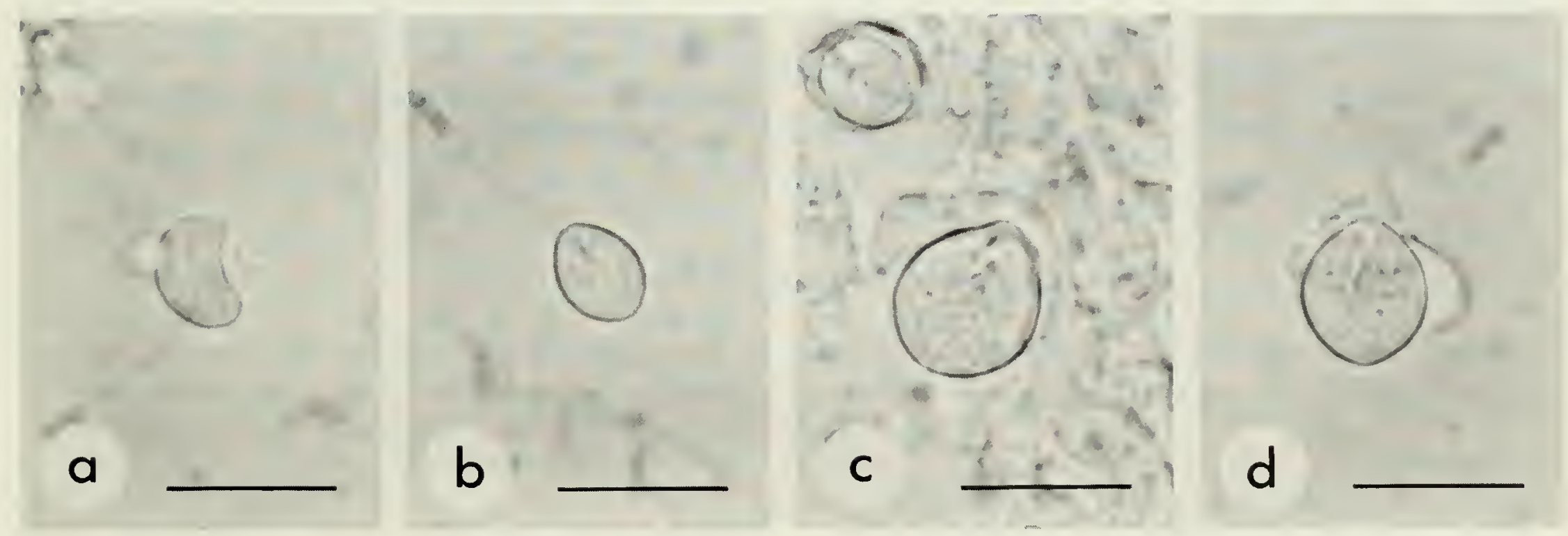

FIG. 52. Zanclea alba, nematocysts of hydranth and young medusa. Scales equal $10 \mu \mathrm{m}$. $a$. Macrobasic eurytele of medusa bud, ROMIz B332. b. Small stenotele of hydranth, ROMiz B170. c, Large stenotele of hydranth, ROMIz B170. d, Stenotele of medusa bud, ROмIz B332. 
1857. and to the species commonly named $Z$. costata Gegenbaur, 1857. Uncertainty lingers about the scope of $Z$. costata (e.g., see Picard, 1957), and this name is predated by four other names as given in the synonymy list above. Accordingly, the species-group name album (as used in the binomen Acrochordium album by Meyen, 1834) is retained, notwithstanding its infrequent use in the literature, and the name Zanclea alba, comb. nov., is recognized here as the valid name of the species.

Russell and Rees (1936) cultured hydroids ascribed to Zanclea implexa (Alder, 1856b) in the laboratory and reared medusae, albeit with difficulty. They showed that a number of differences, formerly used to separate what were believed to be species and even genera, were based on characters that varied with stage of development. In the hydroid, presence or absence of visible perisarc on the hydrorhiza and hydrocaulus was found to vary with age and development of the colony. Likewise, the exact location of medusa-bud formation was shown to be highly variable. In the medusa, arrangement of the nematocyst armature on the exumbrella and thickness of the mesoglea were shown to vary during development. Russell and Rees concluded that the North American Zanclea gemmosa McCrady, 1859a, should be united with the European $Z$. implexa (Alder, 1856b), and they provided a list of synonyms. They provisionally retained Zanclea costata Gegenbaur, 1857, as a separate species because of the presence of four marginal tentacles in the medusa instead of two. However, $Z$. implexa and $Z$. costata were later united by Russell (1953). Coryne sessilis, a hydroid described by Gosse (1853) as having tentacles in whorls, was listed by Russell and Rees (1936) as questionably conspecific with Z. implexa. Brinckmann-Voss (1970) noted a tendency for the tentacles to occur in verticils in hydroids ascribed to $Z$. costata from the Mediterranean; it seems likely that Gosse exaggerated this in his illustrations and description of $Z$. sessilis. Picard (1957) believed that $Z$. costata and $Z$. gemmosa were distinct from $Z$. sessilis, but I have followed Brinckmann-Voss (1970) in regarding the three as conspecific. Zanclea sessilis was regarded as conspecific with Coryne pusilla Gaertner, 1774, by Vervoort (1946b), but this seems quite unlikely considering the small size of Gosse's hydroids (about $1.5 \mathrm{~mm}$ high) and the large number of tentacles present (at least 45).

Hargitt (1908) and Bedot (1925) noted that this species had been misidentified on numerous occasions as Corvnitis agassizii McCrady, 1859a (= Linvillea agassizii). Bedot provided an extensive synonymy list to sort out the nomenclatural confusion.

Weill (1934) reported that the cnidome of a medusa identified as Germmaria gemmosa (McCrady, 1859a) included atrichs as well as macrobasic euryteles and stenoteles. No atrichs were observed in newly liberated medusae of Zanclea alba from Bermuda.

This species, listed under the name Zanclea costata, was reported to be common on pelagic Sargassum by Morris and Mogelberg (1973). Hydroids of Z. alba were common to abundant on pelagic Sargassum at Bermuda during this study.

\section{KNOWN RANGE}

Bermuda: on pelagic Sargassum (Calder, 1986). Elsewhere: apparently circumglobal in tropical and temperate waters (Russell and Rees, 1936; Fraser, 1944; Yamada, 1959; Kramp, 1959, 1961, 1965, 1968; BrinckmannVoss, 1970; Bouillon, 1978c).

\section{Family Milleporidae Fleming, 1828}

Milleporadae Fleming, 1828:528 [emended to Milleporidae by Milne Edwards and Haime, 1849].

\section{DIAGNOSIS}

Hydroid colonies forming massive, calcareous exoskeletons of varied shape. Coenosteum with a complex network of coenosarcal tubes internally, covered externally by a thin epidermal layer, with surface perforated by pores; margins of pores not protruding from surface of coenosteum; larger gastropores surrounded by smaller dactylopores, forming indistinct cyclosystems. Gastrostyles and dactylostyles lacking. Polyps polymorphic; gastrozooids relatively short and stout, with four to seven short capitate tentacles, and arising within gastropores; dactylozooids long, slender, mouthless, with scattered capitate tentacles, and arising from dactylopores.
Gonophores free but reduced medusae, arising from coenosarc within ampullae in coenosteum. Medusae with exumbrellar nematocyst patches; velum and tentacles lacking. Gonads on manubrium.

\section{REMARKS}

Species of the family Milleporidae Fleming, 1828, have been recognized as hydrozoans since the work of $\mathrm{L}$. Agassiz (1858), but their systematic position within the class Hydrozoa has been a matter of longstanding debate. Moseley (1880) referred this family, along with the Stylasteridae Gray, 1847 , to the suborder Hydrocorallinae. The great differences separating milleporids and stylasterids were pointed out by S. J. Hickson (in a note in Delage and Hérouard, 1901), and he placed the former in a new order. the Milleporina. 
Separation of these two families was upheld by Broch (1914) and Stechow (1923a), but they maintained that milleporids were capitate hydroids related to the Corynidae Johnston, 1836. According to a number of recent authors, including Bouillon (1974, 1985) and Petersen (1979), available evidence from hydranth morphology and nematocyst complement suggests that the family has affinities with the Teissieridae Bouillon, 1978c, Zancleidae Russell, 1953, and Cladocorynidae Allman, 1872. Further details on history of the classification of the Milleporidae, together with a taxonomic assessment of the fossil species referred to the family, are given by Boschma $(1951,1956)$.

\section{Genus Millepora Linnaeus, 1758}

Millepora Linnaeus, 1758:790.

Palmipora de Blainville, 1830:356.

\section{DIAGNOSIS}

With the characters of the family.

\section{TYPE SPECIES}

Millepora alcicornis Linnaeus, 1758, by subsequent designation by Apstein (1915).

\section{REMARKS}

The genus Millepora Linnaeus, 1758, originally included a conglomeration of species only one of which, $M$. alcicornis Linnaeus, 1758, is referred to the genus as it is understood at present (Boschma, 1948). There is even some uncertainty about the identity of $M$. alcicornis, which may have been a species of scleractinian and not a hydrozoan. However, Boschma (1948) indicated that there is support for the belief that the $M$. alcicornis sensu Linnaeus was the branched West Indian hydrozoan currently assigned that name. The colony form of this hydrozoan often bears a resemblance to an elk's horn, as reflected in the etymology of the specific name. Moreover, the definition of $M$. alcicornis by Linnaeus (1767) almost certainly refers to the hydrozoan genus Millepora as understood at present, and not to a scleractinian.

Boschma (1948) recounted the differing views concerning species limits in Millepora. These views have ranged from that of Duchassaing and Michelotti (1864), who regarded almost every different growth form as a distinct species, to that of Hickson (1898a, 1898b), who believed that the genus contained a single species, $M$. alcicornis. Hickson's concept of a single species displaying different growth forms or "facies" was widely, although on occasion somewhat grudgingly, accepted through the early decades of the present century. The opinion was gradually superseded by the conclusion that some of the "growth forms" were indeed distinct species. Boschma (1948), in an extensive and influential review of the species problem in Millepora, recognized 10 rather well defined species and discussed the characters used for specific distinction.

De Weerdt (1981) noted that the species of Millepora are currently distinguished principally on the growth form of the corallum and geographic distribution, but growth form is highly influenced by environmental factors such as water movement and turbidity. The taxonomic value of characters such as texture of the corallum surface, size and shape of the gastropores and dactylopores and their distribution over various parts of the corallum, extent to which cyclosystems are isolated, presence or absence of ampullae, morphology of the soft parts, and stinging properties has largely been discounted. However, de Weerdt concluded that such characters, including the shape and size of ampullae, may be of more value taxonomically than supposed and merit re-examination.

\section{Millepora alcicornis Linnaeus, 1758}

Figs. 53-55

Millepora alcicornis Linnaeus, 1758:791.

Millepora alcicornis digitata Esper, 1790:197; pl. 5, figs. 1,2 .

Millepora alcicomis corniculata Esper, 1790:197; pl. 6. Millepora alicornis-Esper, 1790:197 [incorrect subsequent spelling].

Millepora alcicomis ramosa Esper, 1790: 198; pl. 7.

?Millepora alcicornis crustacea Esper, 1790:200 [not Millepora crustacea Linnaeus, 1758].

Millepora alcycornis-Bosc, 1802:288 [incorrect subsequent spelling].

Palmipora alcicornis-de Blainville, 1834:391; pl. 58. fig. 2.

Millepora moniliformis Dana, 1848:544 [not Millepora moniliformis Rafinesque, 1820].

Millepora ramosa-Dana, 1848:544.

Millepora pumila Dana, 1848:545; pl. 52, fig. 4 [not Millepora pumila Pallas, 1766].

Palmipora fasciculata Duchassaing, 1850:18.

Palmipora parasitica Duchassaing. 1850:18.

Millepora forskali Milne Edwards, 1860:228.

Millepora fasciculata-Milne Edwards, 1860:228 [not Millepora fasciculata Lamarck, 1816].

Millepora gothica Duchassaing and Michelotti, 1860:84; pl. 10, figs. 9,10.

Millepora schrammi Duchassaing and Michelotti, 1864:100; pl. 11, fig. 9.

Millepora esperi Duchassaing and Michelott, 1864:100. Millepora crista-galli Duchassaing and Michelotti, 1864:101; pl. 11, fig. 7 |not Millepora crista galli Morren. 1828]. 
Millepora delicatula Duchassaing and Michelotti, 1864:101; pl. 11, fig. 10.

Millepora candida Duchassaing and Michelotti, 1864:101. Millepora digitata-Duchassaing and Michelotti, 1864:102. Millepora carthaginiensis Duchassaing and Michelotti, 1864:102; pl. 11, fig. 6 .

Millepora trinitatis Duchassaing and Michelotti, 1864:102. Millepora fenestrata Duchassaing and Michelotti, 1864:103; pl. 11, fig. 1.

Millepora nitida Verrill, 1868:362.

Millepora alcicornis var. cellulosa Verrill, 1868:363.

Millepora alcicornis var. fenestrata-Verrill, 1868:364.

Montipora gothica-Dollfus, 1936:515.

\section{TYPE LOCALITY}

Not specified by Linnaeus (1758); subsequently given as “O. Indiae utriusque" (Linnaeus, 1767).

\section{MATERIAL EXAMINED}

Whalebone Bay, on ledges at entrance, $-4 \mathrm{~m}, 4$ March 1982, one fragmentary colony, $1.5 \mathrm{~cm}$ high, ROMIZ B 175 . Hall's Island. Harrington Sound, on rocks, $-1 \mathrm{~m}, 13$ September 1977, one fragmentary colony, $6.2 \mathrm{~cm}$ high, liberating medusae when alive, coll. W. Sterrer, ROMIZ B 180. Whalebone Bay, on ledges at entrance, $-2 \mathrm{~m}$, two fragmentary colonies, $2.0-4.5 \mathrm{~cm}$ high, ROMIZ B 181. Flatts Inlet, on shells and rubble, $-4 \mathrm{~m}, 5$ March 1982, one colony, $7.0 \mathrm{~cm}$ high, ROMIZ B304. Flatts Inlet, on rubble, $-3 \mathrm{~m}, 9$ July 1983, one colony, $1.7 \mathrm{~cm}$ high, ROMIz $\mathrm{B} 312$.

\section{DESCRIPTION}

Colonies initially consisting of an encrusting base and fingerlike upright projections; older colonies with extensive upright branches of varied shape. Branches irregularly rebranched, generally in one plane; branchlets fused to varying degrees basally, with tips usually free and digitate. Coenosteum consisting of a framework of anastomosing calcareous trabeculae, interstices occupied by a network of coenosarc tubes, surface covered with an epidermal layer and perforated by pores. Gastropores $0.35 \mathrm{~mm}$ in diameter; dactylopores $0.25 \mathrm{~mm}$ in diameter; cyclosystems distinct to indistinct, with five to nine dactylopores surrounding each gastropore. Gastrostyles and dactylostyles absent. Gastrozooids relatively stout, reaching about $1 \mathrm{~mm}$ above surface of coenosteum when extended, with an oral whorl of four to seven short, capitate tentacles. Dactylozooids long and slender when extended, reaching $1.0-1.5 \mathrm{~mm}$ above surface of coenosteum, with short, capitate tentacles grouped at distal end and scattered elsewhere.

Nematocysts-

Gastrozooids: microbasic mastigophores 30.0-31.9 $\mu \mathrm{m}$ $\times 24.5-26.3 \mu \mathrm{m}$; stenoteles (small) 8.3-8.9 $\mu \mathrm{m} \times 5.7-$

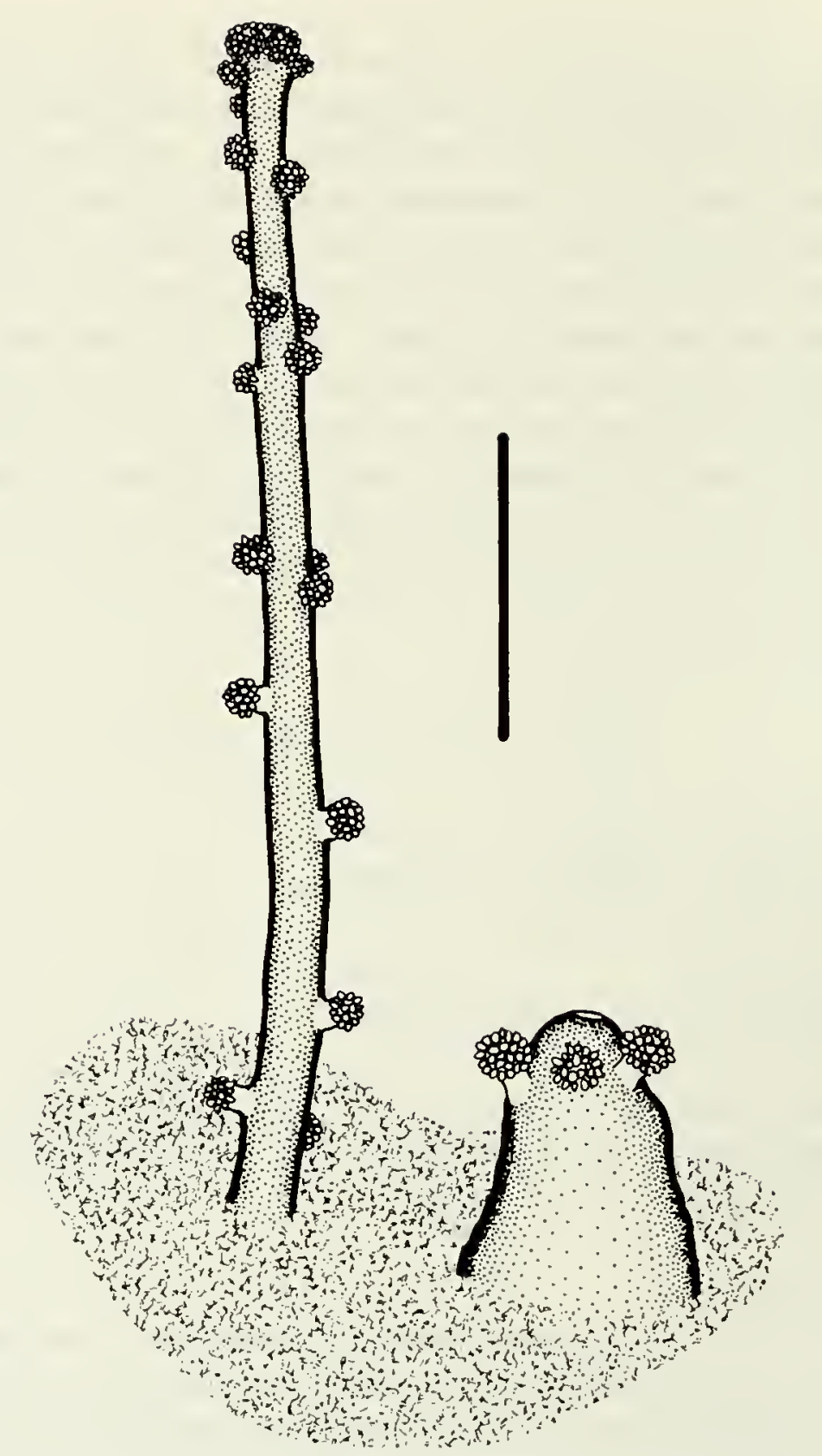

F1G. 53. Millepora alcicornis, dactylozooid and gastrozooid extending above coenosteum, ROMIZ B312. Scale equals 0.25 $\mathrm{mm}$.

$6.6 \mu \mathrm{m}$; stenoteles (medium) 15.9-17.6 $\mu \mathrm{m} \times 12.9-$ $14.2 \mu \mathrm{m}$; stenoteles (large) 21.6-24.7 $\mu \mathrm{m} \times 15.9-$ $18.7 \mu \mathrm{m}$.

Dactylozooids: stenoteles (small) $8.3-8.6 \mu \mathrm{m} \times 5.9-$ $6.5 \mu \mathrm{m}$.

\section{REMARKS}

The synonymy of this species is long and complex. The simplified list given here largely follows that of Boschma (1948).

Millepora alcicornis Linnaeus, 1758, is the only species of its genus known to occur in Bermuda, although two other species, $M$. complanata Lamarck, 1816, and $M$. squarrosa Lamarck, 1816, have been reported elsewhere in the western North Atlantic. Colonies of $M$. alcicornis are highly varied in shape, but they are distinguishable from those of $M$. complanata and $M$. squarrosa in being composed of branches rather than of vertical plates 

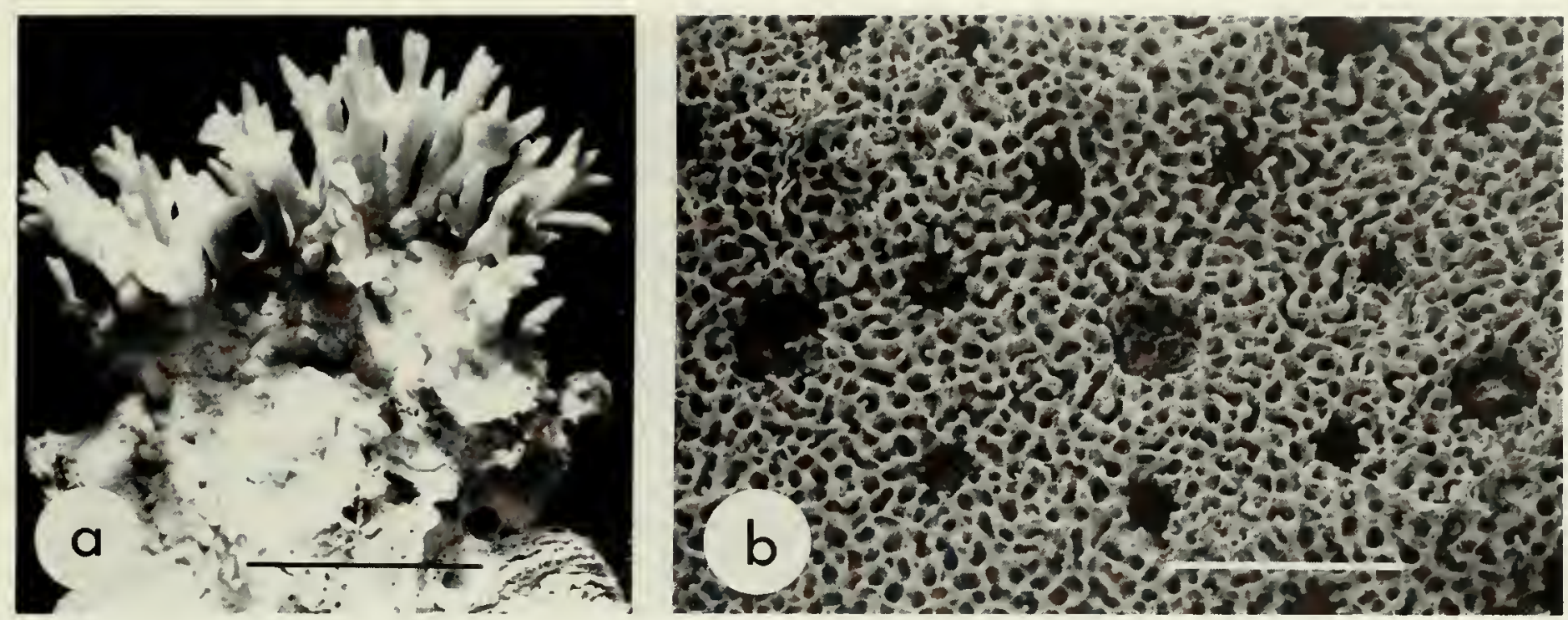

FIG. 54. Millepora alcicornis, coenosteum. Scale for $a$ equals $5 \mathrm{~cm}$; scale for $b$ equals $100 \mu \mathrm{m}$. $a$, Young colony encrusting bivalves and coral rubble, ROMIZ B304. $b$, SEM micrograph of part of coenosteum, showing a cyclosystem, ROMIZ B304.
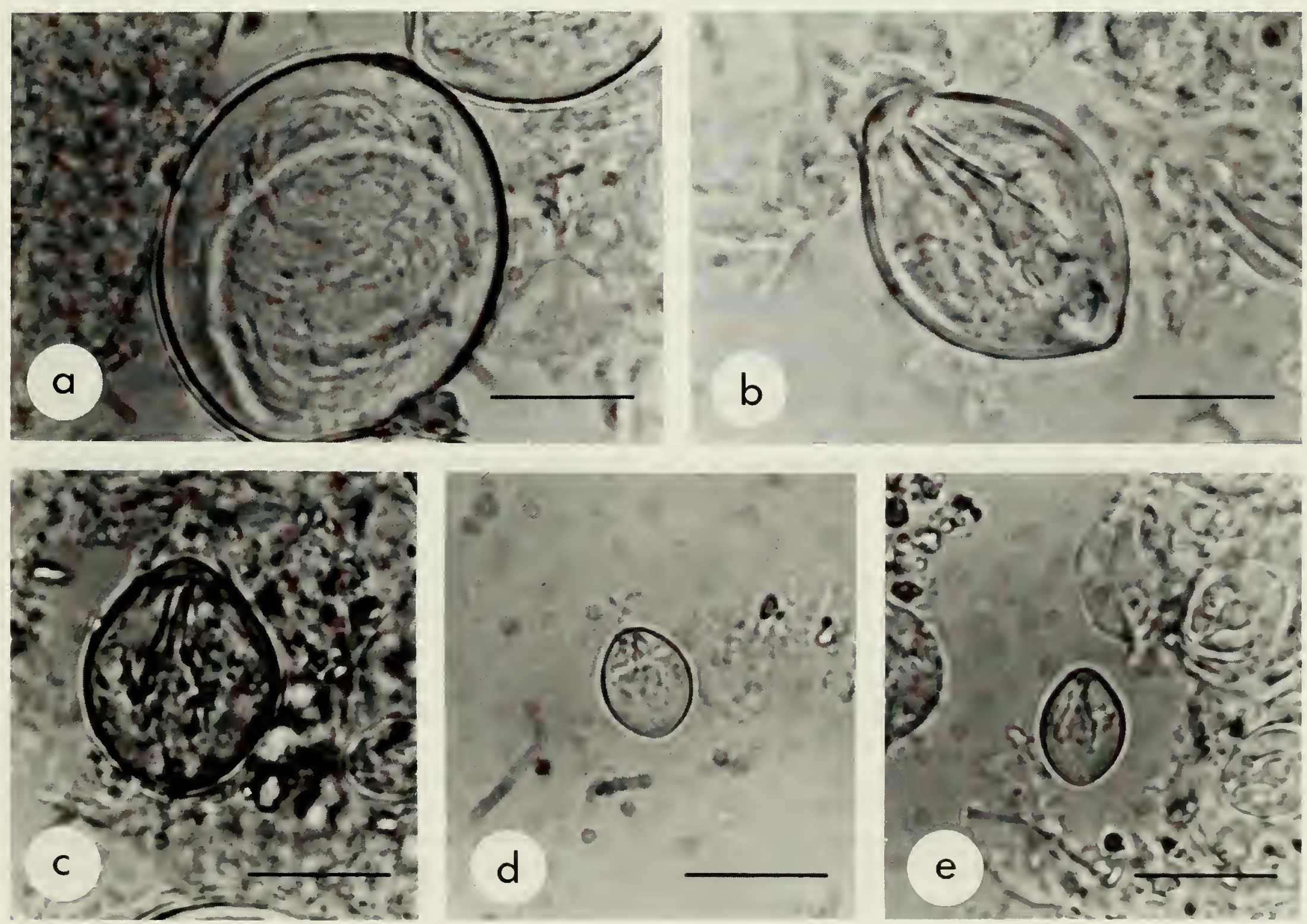

FIG. 55. Millepora alcicornis, nematocysts, Romiz B312. Scales equal $10 \mu \mathrm{m}$. a, Microbasic mastigophore of gastrozooid. b, Large stenotele of gastrozooid. $c$, Medium stenotele of gastrozooid. $d$. Small stenotele of gastrozooid. $e$, Small stenotele of dactylozooid. 
(Boschma. 1948). The vertical plates of $M$. complanata are truncated distally and united only at their bases, while those of $M$. squarrosa are frilled distally and often united above their bases.

Verrill (1907) reported colonies of Millepora alcicornis as large as $4-6$ feet $(1.2-1.8 \mathrm{~m})$ across and $1-2$ feet $(0.3-$ $0.6 \mathrm{~m}$ ) high at Bermuda. He commented that it was the most abundant "coral" on outer reefs and on inner rocks and ledges around the islands, ranging from the shallows to a depth of 5-8 fathoms $(9-15 \mathrm{~m})$. When alive, the species is brownish in colour because of the presence of symbiotic zooxanthellae in the tissues. Millepora alcicor- uis, in common with other species of the genus, is venomous to humans (Verrill, 1907).

A description of the medusa stage of this species is given by Mayer (1910).

\section{KNOWN RANGE}

Bermuda: on reefs, ledges, rocks, and other substrates around the entire Bermuda Platform (Nelson and Duncan, 1876; Moseley, 1876, 1879, 1880; Rice, 1878; Quelch, 1886; Verrill, 1900, 1902a, 1902b, 1907: Moore, 1969: Calder, 1986).

Elsewhere: western Atlantic (Boschma, 1948).

\section{Family Porpitidae Goldfuss, 1818}

Porpitae Goldfuss, 1818:1012 /emended to Porpitidae by Guilding 1828:403].

Velellidae Eschscholtz, 1829:165.

Discalidac Hacckel, 1888a:29.

Porpalidae Haeckel, 1888b:57.

Porpitellidae Haeckel, 1888b:63.

\section{DIAGNOSIS}

Hydroids polymorphic, highly specialized, adapted for life at sea surface. Float and mantle with or without upright sail; undersurface with a large central gastrozooid, a ring of gonozooids, and a peripheral ring of dactylozooids.

Gonophores free medusae. Medusae thimble-shaped with perradial exumbrellar nematocyst rows; mouth simple, circular. Radial canals four. Tentacle bulbs four. Ocelli lacking. Gonad not completely encircling manubrium.

\section{REMARKS}

The family name Porpitidae is frequently attributed to Brandt (1835), but the name was apparently first employed by Goldfuss (1818) as the Porpitae. This name, emended to Porpitidae by Guilding (1828), thus predates the name Velellidae Eschscholtz, 1829, and must be given priority when the two nominal families are combined. I concur with Brinckmann-Voss (1970) and others that the Porpitidae and Velellidae can be contained in a single family.

Chamisso and Eysenhardt (1821) included various nominal species of Porpita Lamarck. 1801, and Velella Lamarck, 1801, under the name Chondrophorae (as "Medusae Chondrophorae"), but it is unclear whether they intended Chondrophorae to be a family-group name. In any case, the name Chondrophorae does not meet the criteria of availability for family-group names [Art. I If (i)(1)], either in its original form or in any of its subsequently emended spellings.

Members of this family have been variously treated as siphonophores (e.g., Eschscholtz, 1829; Huxley, 1859; L.
Agassiz, 1862; Haeckel, 1888a, 1888b; Bigelow, 1911; Moser, 1925), as athecate hydroids (e.g., Kölliker, 1853; Vogt. 1854; McCrady, 1859a: A. Agassiz, 1883; Edwards, 1966b; Brinckmann-Voss, 1970), and as a separate order of Hydrozoa, the Chondrophora (e.g., Totton, 1954; Rees, 1957). The concensus among contemporary workers is that they are highly specialized athecate hydroids (see Edwards, 1966b; Brinckmann-Voss, 1970; Fields and Mackie, 1971; Bouillon, 1974. 1985; Petersen, 1979; Arai and Brinckmann-Voss, 1980; Kirkpatrick and Pugh, 1984; Calder, 1986).

Opinions have differed widely concerning their systematic position within the athecate hydroids. Leloup (1929, 1954), Garstang (1946), Totton (1954), Mackie (1959. 1960), and Daniel (1976), among others, have suggested that they are most closely related to the Corymorphidae Allman, 1872, and Tubulariidae Fleming, 1828. Fields and Mackie (1971) regarded Velella as a large, floating tubulariid hydranth and placed the nominal family Velellidae, together with the Corymorphidae, Tubulariidae, and Margelopsidae Uchida, 1927, in the superfamily Tubularioidea Fleming, 1828. Picard (1955, 1957) and Prévot (1959) included Velella and Porpita, along with the Zancleidae Russell, 1953, in the Pteronematoidea Haeckel, 1879. Brinckmann (1964) believed that their affinities were with the tubularians and placed them in a superfamily, the Chondrophoroidea, in the order Anthomedusae. Later, she suggested that they should be placed between the Capitata and Filifera (Brinckmann-Voss, 1970). Based on the morphology and histological structure of their polyps and medusae, as well as their nematocyst complement, Bouillon (1974) argued that Velella and Porpita had undeniable affinities with the Zancleidae. Petersen (1979) treated them as a superfamily within the Zancleida, a suborder encompassing the Cladocorynidae Allman, 1872, Zancleidae, Teissieridae Bouillon, 1978c, and Milleporidae Fleming, 1828 . 
Most of the available evidence points to the Porpitidae as having an affinity with taxa of the superfamily Zancleoidea Russell, 1953. If such an interpretation is correct, it follows that Porpita and Velella should be interpreted as colonies rather than as individual floating hydranths and that their zooids are true polyps, as argued by Edwards (1966b).

\section{Genus Porpita Lamarck, 1801}

Porpita Lamarck, 1801:355.

Polybrachionia Guilding, 1828:403.

Ratis Lesson, 1830:60.

Acies Lesson, 1830:61.

Chrysomitra Gegenbaur, 1857:232.

Disconalia Haeckel, 1888a:30.

Porpitella Haeckel, 1888a:30 [invalid junior homonym of Porpitella Pomel, 1883 (Echinodermata)].

\section{DIAGNOSIS}

Porpitid hydroids with disc-shaped float and mantle: float flat or with central bulge; sail lacking. Dactylozooids with three vertical rows of short, capitate tentacles.

Medusae with small manubrium. Juvenile specimens without marginal tentacles; adults with one to two slender, decidedly capitate tentacles; endodermal cells along radial canals bearing algal symbionts.

\section{TYPE SPECIES}

Medusa porpita Linnaeus, 1758, by absolute tautonomy.

\section{REMARKS}

Bigelow (1911) retained the name Porpita Lamarck, 1801, for this genus instead of employing Medusa Linnaeus, 1758. Apparently, a type species has never been designated for Medusa, a nominal genus originally containing species of Hydrozoa, Scyphozoa, and Ctenophora, and the name has been scarcely used this century.

The widely used name Porpita Lamarck, 1801, is a junior homonym of Porpita Soldani, 1789 (Protozoa), a name apparently all but abandoned in the recent zoological literature. Application will be made to the ICZN to place Porpita Lamarck, 1801, on the Official List of Generic Names in Zoology, and Porpita Soldani, 1789, on the Official Index of Rejected and Invalid Generic Names in Zoology.

The names Porpita Lamarck, 1801, and Velella Lamarck, 1801, are threatened by Phyllidoce Modeer, 1790 , a nominal genus originally including three nominal species, $P$. denudata (Forskål, 1775), P. porpita (Linnaeus, 1758), and $P$. velella (Linnaeus, 1758). In the interests of nomenclatural stability, the ICZN will be asked in the ap- plication referred to above to use its plenary powers to suppress the seldom-used genus-group name Phyllidoce for the purposes of the Principle of Priority, and to place that name on the Official Index of Rejected and Invalid Generic Names in Zoology. The name Phyllidoce was first used by Browne (1789) for the hydroid known today as Velella velella (Linnaeus, 1758), but Browne's work has been suppressed for nomenclatural purposes by the ICZN (Opinion 89).

Bigelow (1911) recognized Porpema Haeckel, 1888a, as distinct from Porpita, while Totton (1954) believed that the two were congeneric. The taxa appear sufficiently distinct, based on present understanding of their morphology (Bigelow, 1911), to warrant recognition of both as valid genera. Bigelow (1911) regarded Porpalia Haeckel. 1888a, as a synonym of Porpema. Acting as first reviser, he chose Porpema as the valid name of the genus. Discalia Haeckel, 1888 a, is probably a synonym of Porpema as well. Haeckel's (1888a) nominal genera Disconalia and Porpitella were regarded by Bigelow as congeneric with Porpita.

\section{Porpita porpita (Linnaeus, 1758)}

Figs. 56, 57

Medusa porpita Linnaeus, 1758:659.

Holothuria denudata Forskål, 1775:103.

Holothurio denudata Forskål, 1776, pl. 26, figs. L, l [lapsus].

Medusa umbella O. F. Müller, 1776b:297; pl. 9, figs. 2,3. Holothuria muda Gmelin, 1790:3143.

Phytlidoce denudata-Modeer, 1790:201.

Phyllidoce porpita-Modeer, 1790:203.

Porpita indica Lamarck, 1801:355.

Porpita appendiculata Bosc, 1802:155; pl. 18, figs. 5,6. Porpita radiata Bory de St Vincent, 1804:99; pl. 5, figs. 2A-D.

Porpita gigantea Péron and Lesueur, 1807, pl. 31, figs. 6,6a-e.

Porpita forskalea Oken, 1815:111 Iname published in a work rejected for nomenclatural purposes by the ICZN (Opinion 417)].

Porpita nuda-Lamarck, 1816:484.

Porpita glandifera Lamarck, 1816:485.

Porpita gramulata Cranch, 1818:418.

Porpita coerulea Eschscholtz, 1825:744.

Porpita globosa Eschscholtz, 1825:744.

Porpita ramifera Eschscholtz, 1825:745.

Porpita chrysocoma Lesson, 1826, pl. 7, figs. 1, I'.

Porpita atlantica Lesson, 1826, pl. 7, fig. 2.

Porpita pacifica Lesson, 1826, pl. 7, figs. 3,3'.

Porpita moneta Risso, 1826:304.

Medusa nuda-Bory de St Vincent, 1827: 139; pl. 90. figs. $3-5$. 
Medusa glandifera-Bory de St Vincent, 1827:139; pl. 90. figs. 6,7.

Polybrachionia linnacana Guilding. 1828:404; pl. 10, figs. 1,2 .

Porpita forskahli de Haan, 1827:493.

Porpita reinwardtii de Haan, 1827:493.

Porpita kuhlii de Haan, 1827:494.

Porpita mediterranea Eschscholtz, 1829:177.

Porpita umbella Eschscholtz, 1829:179.

Ratis medusae Lesson, 1830:60.

Acies palpebrans Lesson, 1830:61.

Porpita lutkeana Brandt, 1835:41.

Porpita linnaeana-Lesson, 1843:588.

Chrysomitra striata Gegenbaur, 1857:232; pl. 7, figs. 10,11

[medusa].

?Discalia primordialis Haeckel, 1888a:30 [nomen nudum]. Disconalia pectyllis Haeckel, 1888a:30 [nomen nudum]. Disconalia gastroblasta Haeckel, 1888a:30 [nomen nudum]. Porpitella caerulea-Haeckel, 1888a:30 [incorrect subsequent spelling].

Porpitella radiata-Haeckel, 1888a:30.

?Discalia primordialis Haeckel, 1888b:46.

Disconalia pectyllis Haeckel, 1888b:48.

Disconalia gastroblasta Haeckel, 1888b:48; pl. 49, figs. 7-12; pl. 50, figs. $1-10$.

Porpitella pectanthis Haeckel, 1888b:64; pl. 46.

Porpita fungia Haeckel, 1888b:67; pl. 45.

Disconalia ramifera Haeckel, 1888b:357.

Porpitella coerulea-Haeckel, 1888b:358.

Porpita porpita-Schneider, 1898b: 194.

Phyllodice denudata-Bigelow, 1911:352 [incorrect subsequent spelling].

TYPE LOCALITY

"Habitat in India" (Linnaeus, 1758).

\section{MATERIAL, EXAMINED}

Building's Bay, St George's 1sland, washed ashore, 7 October 1984, one colony, $7 \mathrm{~mm}$ in diameter, ROMIz B347. Atlantic Ocean, $10 \mathrm{~km}$ south of Nonsuch Island, 7 May 1984, one colony, rataria stage, $3 \mathrm{~mm}$ in diameter, coll. Paul Bennett, ROMIz B350.

\section{DESCRIPTION}

Hydroid pleustonic, with disc-shaped mantle and internal float; upper surface of mantle and float slightly convex, with a central pore and numerous peripheral stigmata. Mantle $7 \mathrm{~mm}$ wide, with radiating gastrodermal canals; margin soft, flexible; central region firm, with an internal chitinous float consisting of a series of concentric air chambers; a disc-shaped reservoir of nematocytes and nematocysts lying between float and central gastrozooid. Undersurface with a single large, central gastrozooid, a medial band of gono- zooids, and a peripheral band of dactylozooids. Central gastrozooid short and broad with a terminal mouth; tentacles and prominent nematocyst batteries lacking. Dactylozooids tentaculate, with a distal whorl of four capitate tentacles; body with varying numbers of short, small, capitate tentacles in three vertical rows; mouth lacking. Gonozooids clavate, lacking tentacles but with prominent nematocyst batteries encircling mouth, additional nematocyst batteries scattered over body; medusa buds given off in clusters basally.

Nematocysts-

Hydroids: atrichous isorhizas (on gastrozooids, dactylozooids, gonozooids; in nematocyst reservoir) 9.3-13.2 $\mathrm{\mu m}$ $\times 4.2-5.0 \mu \mathrm{m}$; haplonemes (on gastrozooids, dactylozooids) 10.8-14.1 $\mu \mathrm{m} \times 5.6-6.6 \mu \mathrm{m}$; stenoteles (small) (on gastrozooids, dactylozooids, gonozooids; in nematocyst reservoir) 15.6-16.7 $\mu \mathrm{m} \times 10.5-11.5 \mu \mathrm{m}$; stenoteles (large) (on gastrozooids, gonozooids; in nematocyst reservoir) $27.5-30.0 \mu \mathrm{m} \times 21.8-25.3 \mu \mathrm{m}$; stenoteles (bulbous) (on medusa buds) 15.2-16.2 $\mu \mathrm{m} \times 12.7-$ $13.9 \mu \mathrm{m}$.

Rataria "larva" planktonic, with swollen, subspherical central gastrozooid, a medial ring of gonozooids, a peripheral ring of tentaculate dactylozooids, and a small discshaped float and mantle.

Medusae not seen.

\section{REMARKS}

Porpitid taxonomy has advanced relatively little since Bigelow's (1911) insightful study of the group. The synonymy list here is taken in part from Bigelow's work, although Moser (1925) and Totton (1954) have been followed in regarding Porpita porpita (Linnaeus, 1758) from the Indian Ocean, P. umbella (O. F. Müller, 1776b) from the Atlantic Ocean, and $P$. pacifica Lesson, 1826, from the Pacific Ocean as conspecific.

The development of Porpita porpita is known to pass through stages somewhat resembling those of Velella velella (Linnaeus, 1758). Various stages in the life history of this species, including the medusa, rataria "larva," and young pleustonic hydroid, have been described by $\mathrm{A}$. Agassiz (1883), Bigelow (1911), Delsman (1923), and Bouillon (1984b). The medusa, at an advanced stage of its development, has euryteles as part of its cnidome (Bouillon, 1984b, 1985).

A. Agassiz (1883) commented that few specimens of Porpita porpita are stranded on beaches compared with Velella velella. Only one specimen was found on Bermuda beaches during this study, although considerable time was spent looking for the species during four field trips. Porpita porpita has been reported previously from Bermuda by Verrill (1900, as P. limnaeana), and by Totton (1936, as P. umbella). 

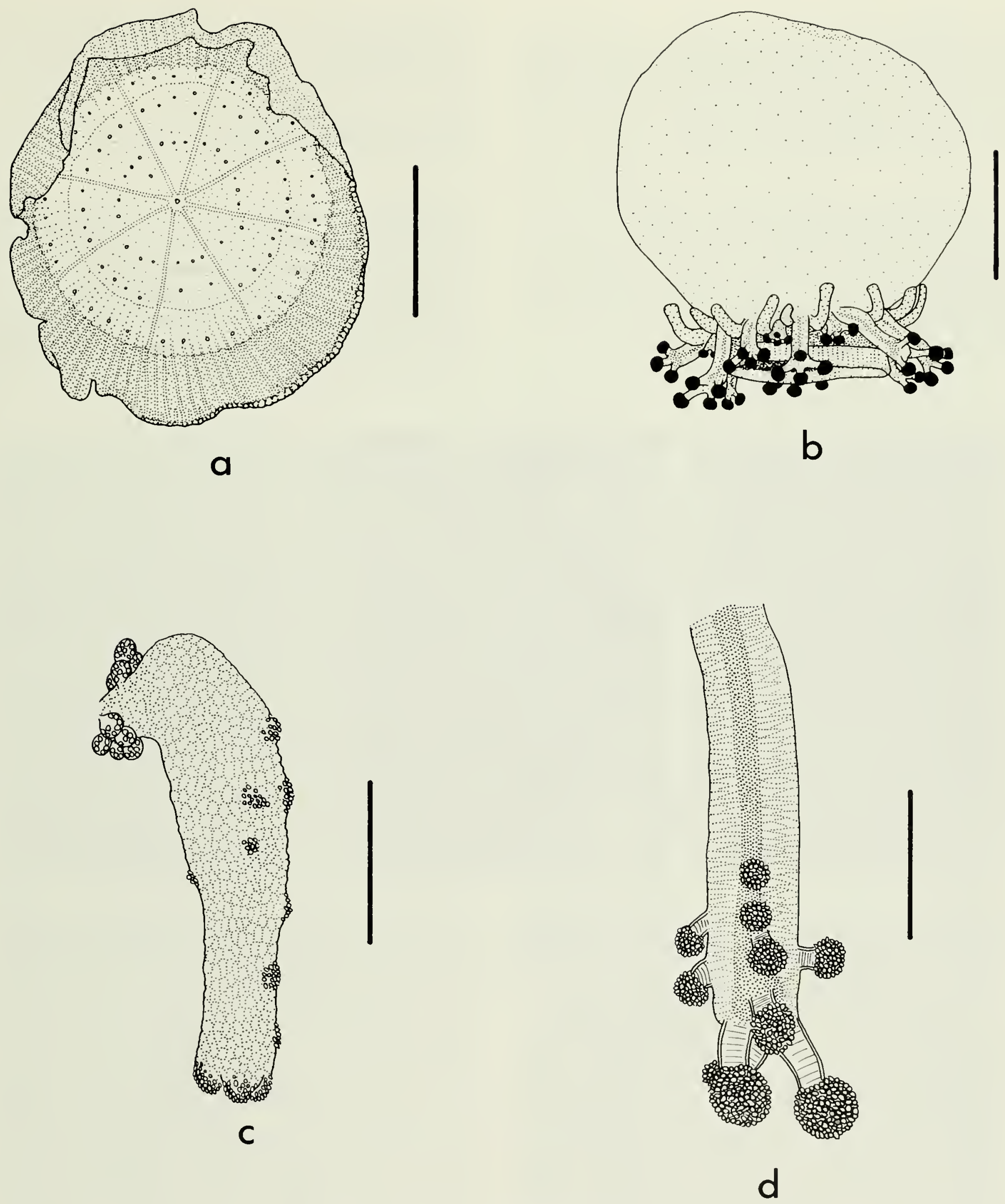

FIG. 56. Porpita porpita. Scale for $a$ equals $2.5 \mathrm{~mm}$; scale for $b$ equals $1 \mathrm{~mm}$; seales for $c$ and $d$ equal $0.5 \mathrm{~mm}$. a. Upper surface of float and mantle, roмгz B347. b. Ritaria larva, коміz B350. c, Gonozooid, with medusa buds, ROMIz B347. d, Dactylozooid, ROM1z B347. 
KNOWN RANGE

Bermuda: no specific locality given (Verrill, 1900; Calder, 1986): $14 \mathrm{~km}$ southeast of Nonsuch Island (Totton, 1936). Elsewhere: circumglobal, tropical and temperate waters (Moser, 1925; Brinckmann-Voss, 1970).

\section{Genus Velella Lamarck, 1801}

Phyllidoce Browne, 1789:387 [invalid name, published in a work suppressed under the plenary powers for nomenclatural purposes by the ICZN (Opinion 89)].

Velella Lamarck, 1801:355.
Vellela Bory de St Vincent, 1827:139 |incorrect subsequent spelling].

Rataria Eschscholtz, 1829:166.

Armenistarium Costa, 1841:187.

Velaria Haeckel, 1888a:31.

Armenista Hacckel, 1888b:83.

\section{DIAGNOSIS}

Porpitid hydroids with oval float and mantle and with upright, triangular sail set diagonal to long axis of float Dactylozooids with nematocyst patches.

Medusae with short, conical manubrium. Tentacle bulbs four, one opposite pair lacking tentacles, each bulb of re-

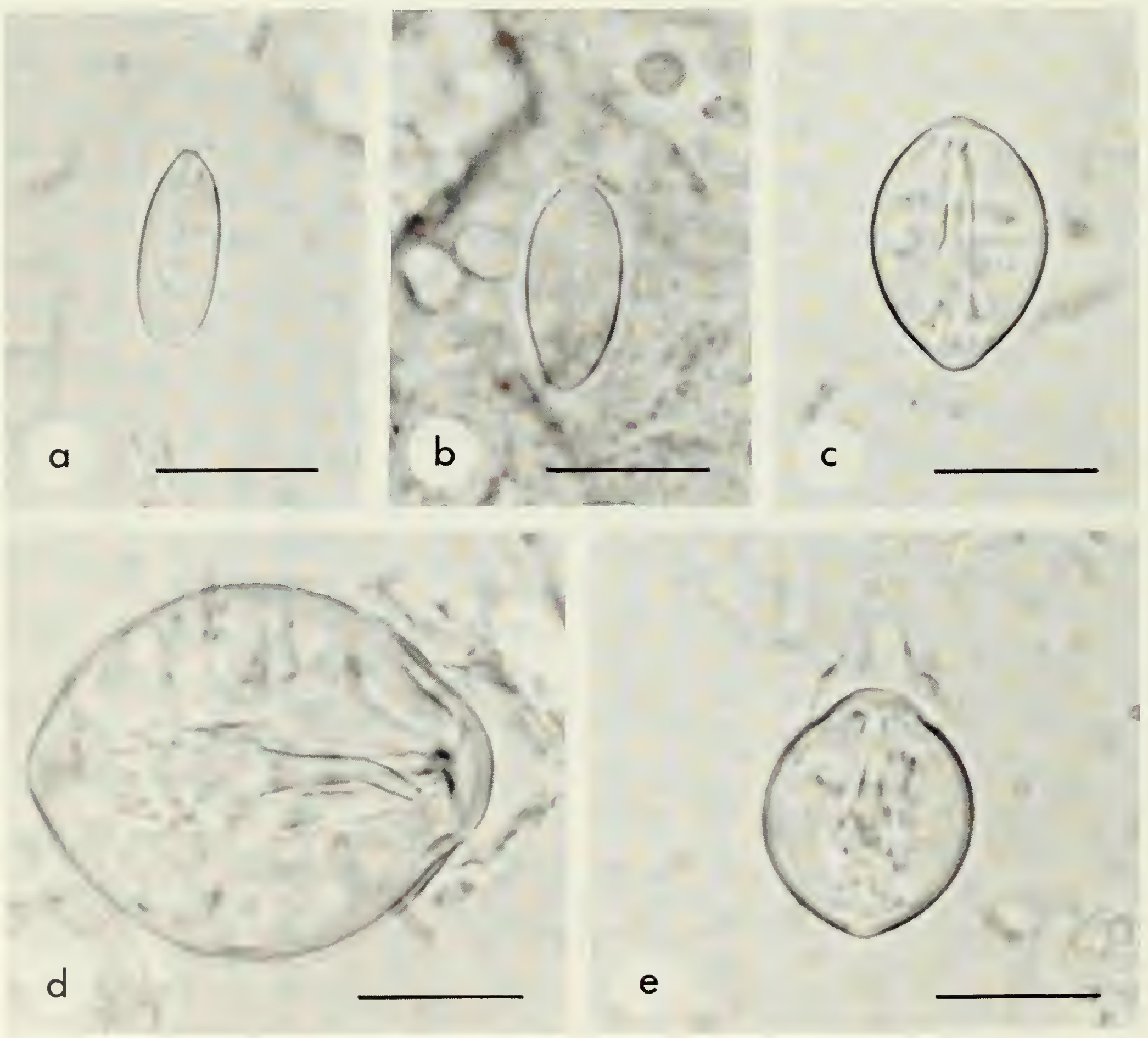

FIG. 57. Porpita porpita, nematocysts of hydroid and medusa bud, romiz B347. Scales equal $10 \mu \mathrm{m}$. $a$, Atrichous isorhiza of dactylozooid. $b$, Haploneme of gastrozooid. c, Small stenotele of dactylozooid. $d$, Large stenotele of gonozooid. $e$, Bulbous stenotele of medusa bud. 
maining pair with one or two capitate tentacles; zooxanthellae concentrated near radial canals and ring canal.

\section{TYPE SPECIES}

Medusa velella Linnaeus, 1758, by absolute tautonomy.

\section{REMARKS}

Numerous nominal species of Velella Lamarck, 1801, have been described over the years from Atlantic, Pacific, and Indian oceans. All of these are currently believed to belong to a single species, $V$. velella (Linnaeus, 1758) (Schneider, 1898b; Bigelow and Sears, 1937; Totton, 1954; Daniel and Daniel, 1963; Brinckmann-Voss, 1970; Daniel, 1976; Arai and Brinckmann-Voss, 1980; Kirkpatrick and Pugh, 1984).

\section{Velella velella (Linnaeus, 1758)}

Figs. 58. 59

Medusa velella Linnaeus, 1758:660.

Holothuria spirans Forskål, 1775:104.

Holothurio spirans Forskål, 1776, pl. 26, figs. K,kl-3 [lapsus].

Phyllidoce velella-Modeer, 1790:194.

Velella mutica Lamarck, 1801:355.

Velella tentaculata Lamarck, 1801:355.

Velella scaphidia Péron and Lesueur, 1807; pl. 30, figs. 6,6a.

Medusa pocillum Montagu, 1815:201; pl. 14, fig. 4.

Velella limbosa Lamarck, 1816:482.

Velella pyramidalis Cranch, 1818:419.

Velella sinistra Chamisso and Eysenhardt, 1821:363; pl. 32, fig. 1.

Velella oblonga Chamisso and Eysenhardt. 1821:364; pl. 32, figs. 2A-C.

Velella lata Chamisso and Eysenhardt, 1821:364; pl. 32. figs. 3A-B.

Velella emarginata Quoy and Gaimard, 1824:586; pl. 86 , fig. 9.

Velella cyanea Lesson, 1826, pl. 6, figs. 3,4.

Velella custralis de Haan, 1827:489.

Velella pacifica de Haan, 1827:490.

Velella radackiana de Haan, 1827:490.

Velella sandwichiana de Haan, 1827:491.

Vellela limbosa-Bory de St Vincent, 1827:139; pl. 90,

figs. 1,2 [incorrect subsequent spelling].

Velella pocillum-Fleming, 1828:500.

Rataria cordata Eschscholtz, 1829:167; pl. 16, fig. 1.

Rataria pocillum-Eschscholtz, 1829:168.

Rataria mitrata Eschscholtz, 1829:168; pl. 16, fig. 2.

Velella aurora Eschscholtz, 1829:171.

Velella septentrionalis Eschscholtz, 1829:171; pl. 15.

fig. 1 .
Velella spirans-Eschscholtz, 1829:172.

Velella caurina Eschscholtz, 1829:173; pl. 15, fig. 2.

Velella tropica Eschscholtz, 1829:174; pl. 15, fig. 3.

Velella indica Eschscholtz, 1829:175; pl. 15, fig. 5.

Velella antarctica Eschscholtz, 1829:175.

Velella patellaris Brandt, 1835:38.

Velella oxvothone Brandt. 1835:39.

Velella oxyothone var. brachyothone Brandt, 1835:39.

Velella oxyothone var. oxyothone Brandt, 1835:39.

Armenistarium velella-Costa, 1841:187; pl. 13, fig. 3

Rataria cristata Haeckel, 1888a:31 [nomen nudum].

Velaria mutica-Haeckel, 1888a:31.

Velaria oblonga-Hacckel, 1888a:31.

Velaria indica-Haeckel, 1888a:31.

Rataria cristata Haeckel, 1888b:79; pl. 44.

Velella patella-Haeckel, 1888b:83 [incorrect subsequent spelling].

Armenista sigmoides Haeckel, 1888b:84; pl. 43.

Armenista mutica-Haeckel, 1888b:84.

Armenista antarctica-Haeckel, 1888b:84.

Armenista indica-Haeckel, 1888b:84.

Armenista lata-Haeckel, 1888b:84.

Armenista lobata Hackel, 1888b:84 [nomen nudum].

Velella meridionalis Fewkes, 1889:112; pl. 1, figs. 1-3: pl. 2, fig. 3 .

Velella velella-Schneider, 1898b:194.

Velella spiralis-Martin, 1904:27 [incorrect subsequent spelling).

Velella subemarginata-Stephens, 1905:65 [incorrect subsequent spelling].

Phyllodice velella-Bigelow, 1911:353 [incorrect subsequent spelling].

\section{TYPE LOCALITY}

"Habitat in Pelago. Loefling. In Mari Mediterraneo. Brander" (Linnaeus, 1758).

\section{MATERIAL EXAMINED}

Warwick Long Bay, washed ashore, 7 March 1982, 30 left-sailing forms, 5-22 $\mathrm{mm}$ long. 3-14 mm wide. and three right-sailing forms, 11-31 mm long, 9-20 $\mathrm{mm}$ wide. ROMIZ B174.

\section{DESCRIPTION}

Hydroids pleustonic, with flattened, oval mantle and internal float; upper surface of mantle and lloat with upright, triangular sail. Specimens occurring in two mirror-image forms, with sail lying along either of two diagonals of mantle and float. Sail with branched and anastomosing radial canals, rather rigidly erect, supported internally by slender, triangular, chitinous extension of floalt. Mantle coursed by radiating gastrodermal camals having short. lateral diverticulae; margin soft, flexible, bearing large numbers of algal symbionts; central region lim. with an 

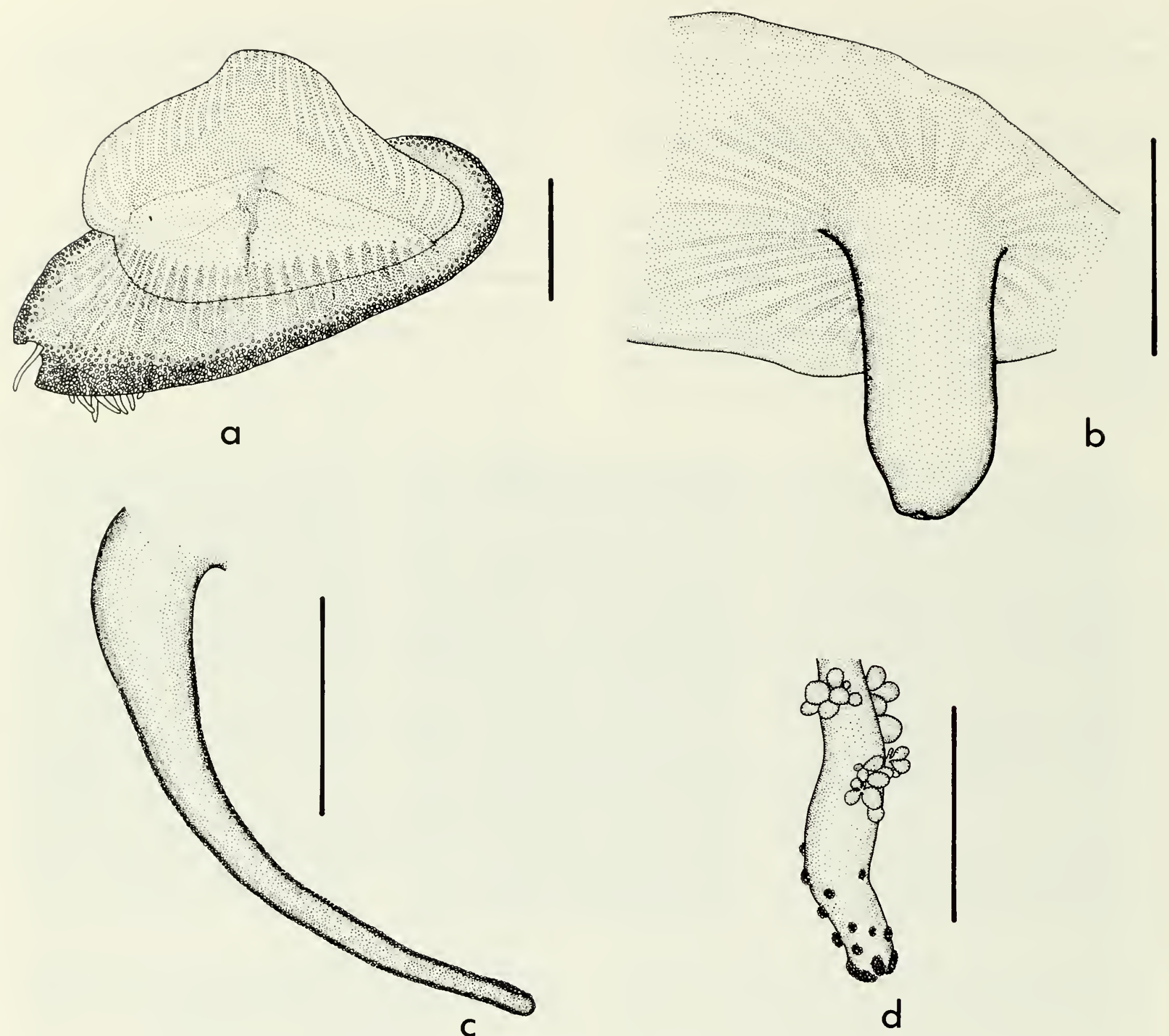

FiG. 58. Velella velella, ROMIz B 174. Scale for $a$ equals $3 \mathrm{~mm}$; scales for $b-d$ equal $2 \mathrm{~mm}$. $a$, Lateral view of float, mantle, and sail. $b$, Gastrozooid. $c$, Dactylozooid. $d$, Gonozooid, with medusa buds.

internal chitinous float consisting of a series of concentric air chambers; an elongate-oval reservoir of nematocytes and nematocysts lying between float and central gastrozooid. Undersurface with a single central gastrozooid, a medial band of gonozooids, and a peripheral band of dactylozooids. Central gastrozooid long and tubular distally with terminal mouth, broad and oval basally, lacking both tentacles and prominent nematocyst batteries; gastrodermis with a series of longitudinal folds. Gonozooids clavate, occurring in various developmental stages, lacking tentacles but with prominent batteries of nematocysts about mouth, additional nematocyst batteries scattered over body; blastostyles given off proximally, each bearing clusters of medusa buds. Dactylozooids tentacle-shaped, oval in crosssection, each bearing a band of nematocysts along the two narrow edges; nematocyst band typically extending up one side and across distal end of dactylozooid, and continuing down opposite side; band often becoming broken up into discontinuous patches proximally; mouth lacking.

Nematocysts-

Hydroids: atrichous isorhizas (on gastrozooids, dactylozooids, gonozooids; in nematocyst reservoir) $8.5-13.6 \mu \mathrm{m}$ $\times 3.8-4.7 \mu \mathrm{m}$; haplonemes (on gastrozooids) 12.7 $14.1 \mu \mathrm{m} \times 6.8-7.6 \mu \mathrm{m}$; stenoteles (small) (on gastrozooids, dactylozooids, gonozooids; in nematocyst reservoir) $12.2-15.1 \mu \mathrm{m} \times 9.2-11.4 \mu \mathrm{m}$; stenoteles (large) 

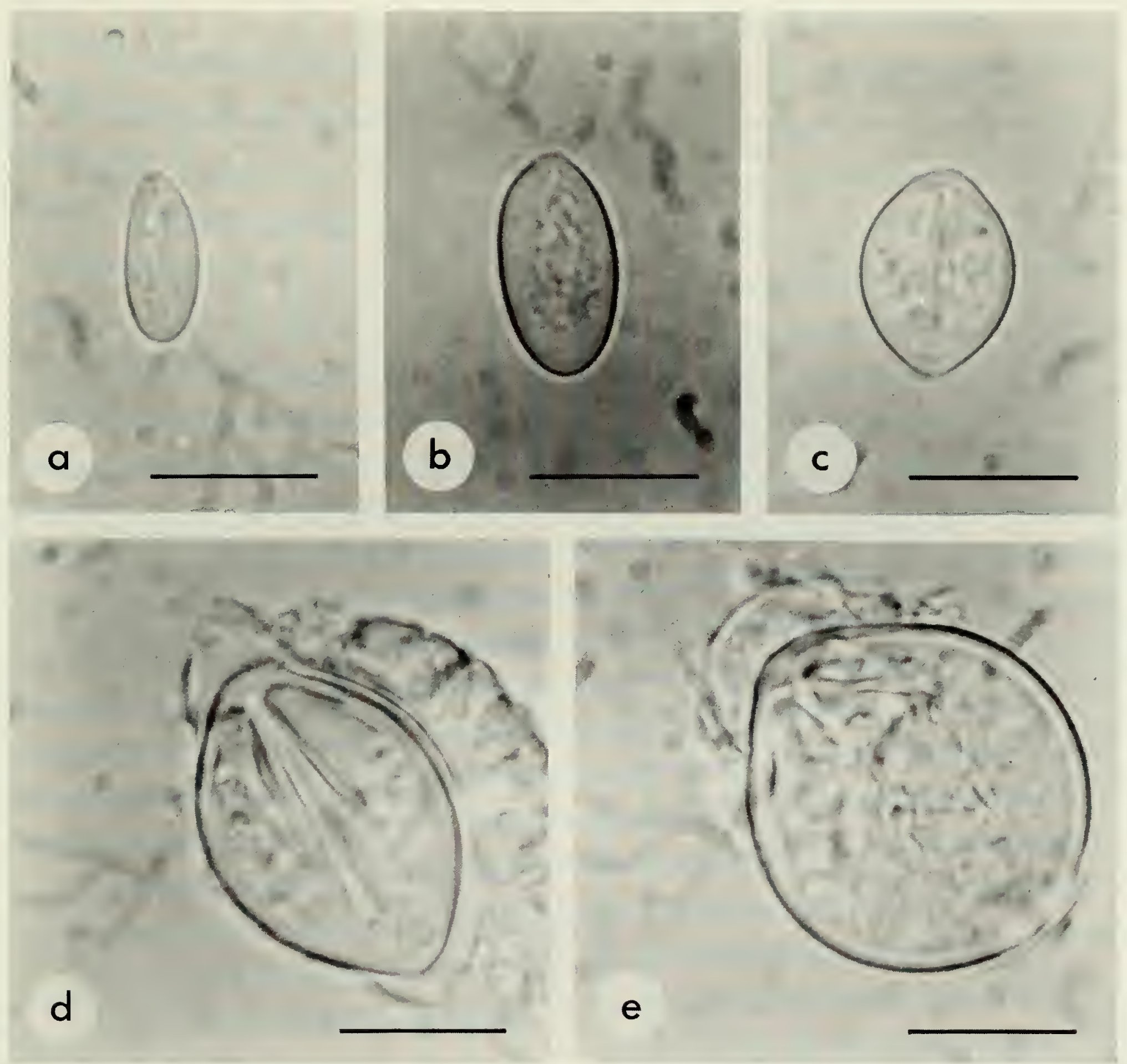

FiG. 59. Velella velella, nematocysts of hydroid, ROMiz B 174. Scales equal $10 \mu \mathrm{m}$. $a$, Atrichous isorhiza of gastrozooid. $b$, Haploneme of gastrozooid. $c$, Small stenotele of dactylozooid. $d$, Large stenotele of dactylozooid. e, Bulbous stenotele of gonozooid.

(on gastrozooids, dactylozooids, gonozooids; in nematocyst reservoir) 18.8-21.2 $\mu \mathrm{m} \times 13.3-15.0 \mu \mathrm{m}$; stenoteles (bulbous) (on gastrozooids, dactylozooids, gonozooids, medusa buds; in nematocyst reservoir) $18.8-23.4 \mu \mathrm{m} \times$ $16.0-21.5 \mu \mathrm{m}$.

Medusae not seen.

\section{REMARKS}

Hydroids of Velella velella (Linnaeus, 1758) occur in two enantiomorphic forms. Edwards (1966b) noted that differing and sometimes conflicting terminology has been used for these two. Edwards has been followed here in designating these as left-sailing and right-sailing forms.
The left-sailing form, which drifts to the left in the downwind direction, corresponds to A. Agassiz's (1883) lefthanded form, Chun's (1897a) "SW" form, and Totton's (1954) "NW" form. The right-sailing form, which drifts to the right in the downwind direction, corresponds to Chun's (1897a) "NW" form and Totton's (1954) "SW" form. Both left-sailing and right-sailing forms were observed washing ashore at Bermuda on 7 March 1982 after several days of strong southerly winds.

The development of the hydroid of Velella velella was described by Woltereck $(1904,1905)$ and reviewed by Garstang (1946). Woltereck found young larvae of this species in deep water off Villefranche, the youngest of 
which possessed a rudimentary, fluid-filled float; two short, solid tentacles; and a rudimentary mouth. Garstang regarded this larva as an actinula, homologous with that of tubularians. Brinckmann-Voss (1970) questioned this, noting that the only similarity between this larva and an actinula was its possession of two aboral tentacles. Growth of this larva, known as a conaria, was accompanied by the development of a nettle-ring (the incipient nematocyst reservoir known as the "centradenia") and a crimson aboral cone of endoderm. Oil droplets, serving as a temporary method of flotation, are secreted by the crimson cone, and the conaria rises to the surface. Upon reaching the surface, fluid in the rudimentary float of the conaria is expelled and replaced by air, and the crimson cone disappears. At this stage, the larva is known as a rataria. In the rataria, the float enlarges and becomes lined with chitin, the nematocyst reservoir or centradenia becomes solid, zooids begin development, and the sail appears. Continued growth of the rataria leads to the familiar hydroid of this species.

Despite the abundance of the hydroid stage and the large numbers of medusa buds produced by each colony, medusae of this species have seldom been collected in nature. Although they have zooxanthellae and are probably epipelagic, the medusae are small and likely easily overlooked. The largest specimen collected to date was only $2.8 \mathrm{~mm}$ high and $2.0 \mathrm{~mm}$ wide (Larson, 1980). Brinckmann (1964) and Brinckmann-Voss (1970) described the development of the medusa in the laboratory.

Rhythmic synchronous contractions, referred to as "concerts" by Fields and Mackie (1971), occur in hydroids of Velella velella (Vogt, 1854; Chun, 1897b; Fields and Mackie, 1971). During a contraction, dactylozooids are flexed towards the central gastrozooid, gonozooids shorten, and the mantle is contracted downwards. Immediately after a contraction, the llexed and contracted parts relax and return to their original state. Fields and Mackie (1971) noted that such contractions may occur singly or in a series, and that concert periodicity in $V$. velella varied from one to three minutes. The function of such behaviour remains enigmatic. Garstang (1946) suggested that it might facilitate the spreading of mucus threads used in prey capture. Fields and Mackie did not attribute such movements either to feeding, as suggested by Garstang, or to locomotion. Because of the presence of large numbers of zooxanthellae in the tissues, they suggested that Chun's (1897b) hypothesis that it is a respiratory movement warranted further evaluation.

\section{KNOWN RANGE}

Bermuda: Castle Harbour (Fewkes, 1883); 14 km southeast of Nonsuch Island (Totton, 1936); no specific locality given (Calder, 1986).

Elsewhere: circumglobal, tropical and temperate waters (Totton, 1954; Edwards, 1966b; Brinckmann-Voss, 1970).

\section{Acknowledgements}

I am indebted to Dr Wolfgang Sterrer, former director of the Bermuda Biological Station, for encouraging me to study the hydroids of Bermuda, and for facilitating my research there in many ways. Funds covering the costs of fieldwork were initially provided by Exxon Corporation. and later by the Canadian Associates of the Bermuda Biological Station and by the Royal Ontario Museum.

I am particularly grateful to Dr Anita Brinckmann-Voss, research associate at the Royal Ontario Museum, for advice, encouragement, and constructive criticism of this work. Special thanks are also extended to Dr P. F. S. Cornclius, of the British Museum (Natural History), for his thorough review of the manuscript. for many kindnesses during my visit there in 1986, and for confirming the identity of the type of Sermularia pennaria Linnacus, 1758, as a species of thecate rather than an athecate. I also acknowledge the helpful comments of an anonymous reviewer. Drs Tom Iliffe, John Markham, and Wolfgang Sterrer provided specimens and information on collecting locales. Jack Lightbourn was most generous in inviting me on offshore collecting trips aboard North Star and
Polaris. Harry Barnes, Warren Snith, Michael Rhodes, and Sue Jickells of the Bermuda Biological Station staff provided help in collecting specimens. Loans of study material were provided by Ardis Johnston, Agassiz Museum of Comparative Zoology; Peter Davis, The Hancock Museum; Peter Frank, National Museum of Natural Sciences; and David Rackley, United States Fish and Wildlife Service.

I wish to thank Barbarann Ruddell, Maureen Mahler. and Stephen Campbell for assisting with the preparation of the manuscript. Librarians at the University of Toronto, the Royal Ontario Museum, and especially the British Museum (Natural History) provided help in locating and obtaining obscure references. Eric Lin, Department of Zoology, University of Toronto, prepared the SEM micrograph of Millepora alcicornis. Histological sections of Zyzzyzus warreni were prepared by Cary Gilmour, Laboratory of Analytical Systematics, Royal Ontario Museum.

This is contribution number 1156 from the Bermuda Biological Station. 


\section{Literature Cited}

AGASSIZ. A

1865 North American Acalephae. Illustrated Catalogue of the Museum of Comparative Zoölogy, at Harvard College, no. 2. 234 pp.

1883 Exploration of the surface fauna of the Gulf Stream under the auspices of the Coast Survey. III. Part 1. The Porpitidae and Velellidae. Memoirs of the Museum of Comparative Zoölogy at Harvard College $8(2): 1-16$.

AGASSIZ, L.

1849 Contributions to the natural history of the Acalephae of North America. Part 1. On the naked-eyed medusae of the shores of Massachusetts, in their perfect state of development. Memoirs of the American Academy of Arts and Sciences 4:221-316.

1858 The animals of Millepora are hydroid acalephs and not polyps. American Journal of Science and Arts, 2nd series, 26:140-141.

1860 Contributions to the natural history of the United States of America. Vol. III. Boston, Little, Brown. 301 pp.

1862 Contributions to the natural history of the United States of America. Vol. IV. Boston, Little, Brown. 380 pp.

ALDER, J.

1856a A notice of some new genera and speeies of British hydroid zoophytes. Annals and Magazine of Natural History, 2nd series, 18:353-362.

1856b Deseriptions of three new British zoophytes. Annals and Magazine of Natural History, 2nd series, 18:439441 .

1857 A catalogue of the zoophytes of Northumberland and Durham. Transactions of the Tyneside Naturalists. Ficld Club 3:93-162.

1862 Supplement to a catalogue of the zoophytes of Northumberland and Durham. Transactions of the Tyneside Naturalists` Field Club 5:225-247.

ALLMAN, G. J.

1844 Synopsis of the genera and species of zoophytes in habiting the fresh waters of Ireland. Annals and Magazine of Natural History 13:328-331.

1859a Notes on the hydroid zoophytes. Annals and Magazine of Natural History, 3rd series, 4:48-55.

$1859 \mathrm{~b}$ Notes on the hydroid zoophytes. Annals and Magazine of Natural History, 3rd series, 4:367-370.

1861 Notes on the hydroid zoophytes. Annals and Magazine of Natural History, 3rd series, 8:168-173.

1863 Notes on the Hydroida. 1. On the structure of Corymorpha nutans. 11. Diagnoses of new species of Tubularidae obtained, during the autumn of 1862, on the coasts of Shetland and Devonshire. Annals and Magazine of Natural History, 3rd series, 11:1-12.

1864a On the construction and limitation of genera among the Hydroida. Annals and Magazine of Natural History, 3rd series, 13:345-380.

1864b Notes on the Hydroida. Annals and Magazine of Nattural History. 3rd series, 14:57-64.

1871 A monograph of the gymnoblastic or tubularian hy- droids. In two parts. 1. The Hydroida in general. London, Ray Society, pp. 1-154.

1872 A monograph of the gymnoblastic or tubularian hy droids. Conclusion of Part 1, and Part I1, containing descriptions of the genera and species of the Gymnoblastea. London, Ray Society. pp. 155-450.

1876 Diagnoses of new genera and species of Hydroida. Journal of the Linnean Society, Zoology 12:25 I-284.

1877 Report on the Hydroida collected during the exploration of the Gulf Stream by L. F. de Pourtalès, assistant United States Coast Survey. Memoirs of the Museum of Comparative Zoölogy at Harvard College $5(2): 1-66$

1888 Report on the Hydroida dredged by H.M.S. Challenger during the years 1873-76. Part 11.-The Tubularinae, Corymorphinae. Campanularinae, Sertularinae. and Thalamophora. Report on the Scientific Results of the Voyage of H.M.S. Challenger during the Years 1873-76. Zoology, 23:1-90.

ANKIEL. W. E.

1952 Phyllirrhoe bucephala Pér. \& Les., und die Meduse Mrestra parasites Krohn. Pubblicazioni della Stazione Zoologiea di Napoli 23:91-140.

ANNANDALE, N

1907 The fauna of brackish ponds at Port Canning. Lower Bengal. Part IV.-Hydrozoa. Records of the Indian Museum 1:139-144.

1915 Fauna of the Chilka Lake. The coelenterates of the lake, with an account of the Actiniaria of brackish water in the Gangetic delta. Memoirs of the Indian Museum 5:65-114.

ANTSULEVICH. A. E. and D. G. POLTEVA

1986 Gidroidy roda Rhizogeton (Athecata. Clavidae) v faune SSSR. Zoologicheskii Zhurnal 65:965-972.

APSTEIN, C.

1915 Nomina conservanda. Sitzungsberichte der Gesellschaft Naturforschender Freunde zu Berlin 1915. pp. 119-202

ARAI, M. N.

in Cnidaria. In Margolis, L., and Z. Kabata. eds., Guide

press to the parasites of fishes of Canada. Ottawa. Canadian Special Publication of Fisheries and Aquatic Sciences.

ARAI, M. N and A BRINCKMANN-VOSS

1980 Hydromedusae of British Columbia and Puget Sound. Canadian Bulletin of Fisheries and Aquatic Sciences 204: 1-192.

AURIVILLIUS, C. W. S

1898 Vergleichende thiergeographische Untersuchungen über die Plankton-Fauna des Skageraks in den Jahren $1893-$ 1897. Kongliga Svenska Vetenskaps-Akademiens Handlingar, Ny Följd, 30(3): 1-426.

AYRISS, W.O

1854 A deseription of a new species of polyp from Long Island, allied to Tubularia, under the name of Globiceps tiarella Ayres. Proceedings of the Boston Society of Natural History 4:193-195 
BABNIK. P

1948 Hidromeduze iz srednjega in Juznega jadrana V Letih 1939. In 1940. Acta Adriatica 3:275-348.

BALE, W. M.

1884 Catalogue of the Australian hydroid zoophytes. Sydney, Australian Muscum, Catalogue No. 8.198 pp.

1894 Further notes on Australian hydroids, with descriptions of some new species. Proceedings of the Royal Socicty of Victoria, n.s., 6:93-117.

1913 Further notes on Australian hydroids. I1. Proceedings of the Royal Society of Victoria, n.s., 26:114-147.

BEDOT, M

1901 Matériaux pour servir à l'histoire des hydroïdes. I re période. Revue Suisse de Zoologie 9:379-515.

1905 Matériaux pour servir à l'histoire des hydrö̈des. 2me période (1821 à 1850). Revue Suisse de Zoologie 13:1-183.

1910 Matériaux pour servir à l'histoire des hydrö̈des. 3me période (1851 à 1871). Revue Suisse de Zoologie $18: 189-490$.

1912 Matériaux pour servir à l'histoire des hydroïdes. 4me période (1872 à 1880). Revue Suisse de Zoologie 20:213-469.

1916 Matériaux pour servir à l'histoire des hydrö̈des. 5e période (1881 à 1890). Revue Suisse de Zoologie 24:1-349.

1918 Matériaux pour servir à l'histoire des hydroïdes. 6e période (1891 à 1900). Revue Suisse de Zoologie 26. Fasc. Suppl. 1:1-376.

1925 Matériaux pour servir à l'histoire des hydroïdes. 7me période (1901 à 1910). Revuc Suisse de Zoologie 32. Fasc. Suppl. 1:1-657.

BENNITT, R.

1922 Additions to the hydroid fauna of the Bermudas. Proceedings of the American Academy of Arts and Sciences $57: 241-259$

BERRILL, N. J.

1948 The life cycle of Aselomaris michaeli, a new gymnoblastic hydroid. Biological Bulletin 95:289-295.

1953 Growth and form in gymnoblastic hydroids. VII. Growth and reproduction in Syncoryne and Coryne. Journal of Morphology 92:273-302.

BIGELOW, H. B

1904 Medusae from the Maldive Islands. Bulletin of the Museum of Comparative Zoölogy at Harvard College 39:245-269.

1911 Reports on the scientific results of the expedition to the eastern tropical Pacific, in charge of Alexander Agassiz, by the U.S. Fish Commission steamer "Albatross", from October, 1904, to March, 1905, Lieut. Commander L. M. Garrett, U.S.N., commanding. XXIII. The Siphonophorac. Memoirs of the Museum of Comparative Zoölogy at Harvard College 38(2): 173402 .

1913 Medusac and Siphonophorae collected by the U.S. Fisheries steamer "Albatross" in the northwestern Pacific, 1906. Proceedings of the United States National Museum 44:1-119.

1918 Some medusac and Siphonophorac from the western
Atlantic. Bulletin of the Museum of Comparative Zoölogy at Harvard College 62:365-442.

1938 Plankton of the Bermuda Occanographic Expeditions. V1II. Medusae taken during the years 1929 and 1930 Zoologica 23:99-189.

BIGELOW, H. B. and M. SEARS

1937 Siphonophorae. Report on the Danish Occanographical Expeditions 1908-10 to the Mediterranean and Adjacent Seas, Vol. II, Part H2. 144 pp.

BLAINVILLE, H. M. D. de

1830 Zoophytes. In Levrault, F. G.. ed.. Dictionnaire des sciences naturelles...par plusieurs professcurs du Jardin du Roi, et des principales Écoles de Paris. Tome 60. Paris, Le Normant, pp. 1-548.

1834 Manuel d'actinologie ou de zoophytologic. Paris, Levrault. 694 pp.

BOERO, F

1981 Systematics and ecology of the hydroid population of two Posidonia oceanica meadows. Pubblicazioni della Stazione Zoologica di Napoli I (Marine Ecology) 2: 181 197.

BONNEVIE, $K$.

1898 Zur Systematik der Hydroiden. Zeitschrift für Wissenschaftliche Zoologie 63:465-495.

1899a Hydroida. Den Norske Nordhavs-Expedition 18761878, Zoologi, 7. 103 pp.

$1899 \mathrm{~b}$ Neue norwegische Hydroiden. Bergens Muscums Aarbog, 1898, 5:1-26.

BOONE, L.

1938 Scientific results of the world cruises of the yachts "Ara", in 1928-1929, and "Alva", 1931-1932.

"Alva" Mediterranean cruise, 1933, and "Alva" South American cruise, 1935, William K. Vanderbilt, commanding. Part II. Coelenterata. Bulletin of the Vanderbilt Marine Muscum 7:29-76.

BORRADAILE, L. A

1905 Hydroids. The Fauna and Geography of the Maldive and Laccadive Archipelagoes 2(4):836-845.

BORSTAD, G. A. and A. BRINCKMANN-VOSS

1979 On Pelagiana trichodesmiae n.gen.. n.sp., family Pandeidae, (Anthomedusae/Athecatac, Cnidaria), a new hydrozoan associated with the planktonic cyanophyte Trichodesmium thiebautii. Canadian Journal of Zoology 57: 1232-1237.

BORY DE ST VINCENT, J. B. G. M

1804 Voyage dans les quatre principales Îles des Mers d'Afrique. Tome 1. Paris, Buisson. 408 pp.

1827 Tableau encyclopédique et méthodique des trois règnes de la nature, contenant l'helminthologie, ou les vers infusoires, les vers intestins, les vers mollusques, etc. Paris, Panckoucke, pp. 83-180.

BOSC, L. A. G.

1802 Histoire naturelle des vers, contenant leur description et leurs moeurs; avec figures dessinées d'après nature. Tome 2, Paris, Guilleminet. 300 pp.

BOSCHMA, H.

1948 The species problem in Millepora. Zoologische Verhandelingen $1: 1-115$.

1951 Notes on Hydrocorallia. Zoologische Verhandelingen $13: 1-49$ 
1956 Milleporina and Stylasterina. In Moore, R. C., ed., Treatise on invertcbrate paleontology. Part F. Coelenterata. Lawrence, University of Kansas Press, pp. F90-F106.

BOUILLON, J.

1971 Sur quelques hydroïdes de Roscolf. Cahiers de Bio logie Marine 12:323-364.

1974 Description de Teissiera milleporoides, nouveau genre et nouvelle espèce de Zancleidae des Seychelles ( $\mathrm{Hy}$ drozoaires; Athécates-Anthoméduses), avec une révision des hydroïdes "Pteronenatoidea." Cahiers de Biologie Marine 15:113-154.

1978a Hydroméduses de l'Archipel des Séchelles et du Mozambique. Revue de Zoologic Africaine 92:117-172.

1978b Station Biologique Leopold 111, Laing 1sland. Contribution no. 1. Sur un nouveau genre et une nouvelle espèce de Ptilocodiidae Hydrichthelloides reticulata et la super-famille des Hydractinoidea (HydroidaAthecata). Stecnstrupia 5(6):53-67.

1978c Hydroméduses de la mer de Bismarck (Papouasie, Nouvelle-Guinée). I. Anthomedusae Capitata (Hydrozoa-Cnidaria). Cahiers de Biologie Marine 19:249297.

1980 Hydroméduses de la mer de Bismarck (Papouasic, Nouvelle-Guinée). III. Anthomedusae Filifera (Hydrozoa-Cnidaria). Cahiers de Biologie Marine 21:307344.

1984a Sphaerocoryne peterseni: nouvelle espèce d'Anthoméduse de Papouasie Nouvelle-Guinée (HydrozoaCnidaria). Indo-Malayan Zoology 1(1984):245-248.

1984b Sur la méduse de Porpita porpita (Linné, 1758) (Velellidae, Hydrozoa, Cnidaria). Indo-Malayan Zoology 1(1984):249-254.

1985 Essai de classification des hydropolypes-hydroméduses (Hydrozoa-Cnidaria). Indo-Malayan Zoology 1( 1985):29-243.

BRANDT, J. F.

1835 Prodromus descriptionis animalium ab $\mathbf{H}$. Mertensio in orbis terrarum circumnavigatione observatorum. Fasc. 1. Polypos, Acalephas Discophoras et Siphonophoras, nec non Echinodermata continens. St Petersburg, Sumptibus Academiae. 75 pp.

BRIGGS, E. A. and V. E. GARDNER

1931 Hydroida. Great Barrier Reef Expedition, Scientific Reports 4:181-196.

BRIGGS, J. C.

1974 Marine zoogeography. New York, McGraw-Hill. 475 pp.

BRINCKMANN, A.

1964 Observations on the structure and development of the medusa of Velella velella (Linné, 1758). Videnskatbelige Meddelelser fra Dansk Naturhistorisk Forening i Kjøbenhavn 126:377-386.

1965 The biology and development of Rhysia autummalis gen.n., sp.n. (Anthomedusae/Athecatac, Rhysiidac fam.n.). Canadian Journal of Zoology 43:941-952.

BRINCKMANN, A and K. W. PETERSEN

1960 On some distinguishing characters of Dipurena reesi Vannucci, 1956 and Cladonema radiatum Dujardin.
1843. Pubblicazioni della Stazione Zoologica di Napoli $31: 386-392$

BRINCKMANN-VOSS. A

1970 Anthomedusae/Athecatae (Hydrozoa, Cnidaria) of the Mediterranean. Part 1. Capitata. Fauna e Flora del Golfo di Napoli, Monografia 39:1-96.

1985 Hydroids and medusae of Sarsia apicula (Murbach and Shearer, 1902) and Sarsia princeps (Haeckel, 1879) from British Columbia and Puget Sound with an evaluation of their systematic characters. Canadian Journal of Zoology 63:673-681.

BROCH, $\mathrm{H}$.

1909 Die Hydroiden der Arktischen Meere. Fauna Arctica 5:129-247.

1914 Stylasteridae. The Danish Ingolf-Expedition. Vol. 5, no. $5.25 \mathrm{pp}$.

1916 Hydroida (Part I). The Danish Ingolf-Expedition. Vol. 5 , no. $6.66 \mathrm{pp}$.

BROOKS, w. K.

1883a List of medusae found at Beaufort, N.C., during the summers of 1880 and 1881. Studies from the Biological Laboratory, Johns Hopkins University 2:135146.

1883b Notes on the medusae of Beaufort, N.C. Part II. Studies from the Biological Laboratory, Johns Hopkins University 2:465-475.

1886 The life-history of the Hydromedusae: a discussion of the origin of the medusae, and of the significance of metagenesis. Memoirs of the Boston Society of Natural History 3:359-430.

BROWNE, E. T.

1900 The fauna and flora of Valencia Harbour on the west coast of 1reland. I. The pelagic fauna (1895-98). 11. The medusae (1895-98). Proceedings of the Royal Irish Academy, series 3, 5:667-736.

1905 A report on the medusae found in the Firth of Clyde (1901-1902). Proceedings of the Royal Society of Edinburgh 25:738-778.

1907 The hydroids collected by the Huxley from the north side of the Bay of Biscay in August 1906. Journal of the Marine Biological Association of the United Kingdom 8:15-36.

BROWNE, P.

1789 The civil and natural history of Jamaica. Edition 2. London, B. White. $503 \mathrm{pp}$.

BRÜCKNER, E.

1914 Beitrag zur Kenntnis von Perigonimus cidaritis Weismann und Gemmaria implexa var. neapolitana Hargitt. Zeitschrift für Wissenschaftliche Zoologic 111:445505.

BUMPUS, H. C.

1898 The breeding of animals at Woods Holl during the months of June, July and August. Science, n.s., 8:850858 .

CAIRNS, S. D

1984 A generic revision of the Stylasteridae (Coelenterata: Hydrozoa). Part 2: Phylogenetic analysis. Bulletin of Marine Science 35:38-53 
CALDI:R, D R.

1970 Hydroid and young medusa stages of Dipurena strangulata (Hydrozoa, Corynidae). Biological Bulletin 138:109-114.

1971 Hydroids and hydromedusae of southem Chesapeake Bay. Virginia Institute of Marine Science, Special Papers in Marine Seience 1:1-125.

1972 Some athecate hydroids from the shelf waters of northern Canada. Journal of the Fisheries Research Board of Canada 29:217-228.

1974 The mud-dwelling hydrozoan Boreohydra simplex in the western North Atlantic. Journal of the Fisheries Research Board of Canada 31:1666-1667.

1975 Biotic census of Cape Cod Bay: hydroids. Biological Bulletin 149:287-315.

1986 Class Hydrozoa. In Sterrer, W.. ed., Marine fauna and flora of Bermuda: a systematic guide to the identification of marine organisms. New York, WileyInterscience, pp. 127-155.

CALDER, D. R. and I3 S. HESTER

1978 Phylum Cnidaria. In Zingmark, R. G., ed., An annotated checklist of the biota of the coastal zone of South Carolina. Columbia. University of South Carolina Press, pp. 87-93.

CARUS, $J \mathrm{~V}$

1885 Prodromus faunac Mediterraneae sive descriptio animalium Mare Mediterranei incolarum quam comparata silva rerum quatenus innotuit adiectis locis et nominibus vulgaribus eorumque auctoribus in commodum zoologorum. Vol. 1. Stuttgart. E. Schweizerbart'sche Verlagshandlung. $524 \mathrm{pp}$.

CASTRIC-FEY, A

1970 Sur quelques hydraires de l'Archipel de Glénan (SudFinistère). Vie et Milieu 21:1-23.

CAVOLINI, F.

1785 Memorie per servire alla storia de polipi marini. Napoli. $279 \mathrm{pp}$.

CHAMISSO. A de and C. G EYSENIIARDT

1821 De animalibus quibusdam e classe vermium Linneana, in circumnavigatione terrac, auspicante Comite $\mathrm{N}$. Romanzoff, duce Ottone de Kotzcbue, annis 18151818. Fisc. 2. Reliquos vermes continens. Nova Acta Physico-Medica Academiac Caesareae LcopoldinoCarolinae Naturae Curiosorum 10:343-374.

CHIAJE, S. delle

1841 Animali senza vertebre del regno di Napoli. 1. Descrizione e notomia degli animali invertebrati della Sicilia citcriore osservati vivi negli anni 1822-1830. Tomo 5. Polipi, Amorfi, descrizioni tecniche. Napoli, C. Batclli.

CHRISTIANSEN, B. O

1972 The hydroid fauna of the Oslo Fiord in Norway. Norwegian Journal of Zoology 20:279-310.

CHUN, C

1897a Die Siphonophoren der Plankton-Expedition. Ergebnisse der Atlantic Plankton-Expedition 2, Kb. $126 \mathrm{pp}$.

1897b Über den Bau und die morphologische Auffassung der Siphonophoren. Verhandlungen der Deutschen Zoologischen Gesellschaft 7:48-111.
CLARK, S. D. and C. B. COOK

1986 Inhibition of nematocyst discharge during feeding in the colonial hydroid Halocordyle disticha ( = Pennaria tiarella): the role of previous prey-killing. Biological Bulletin 171:405-416.

CLARKE, S. F.

1879 Report on the Hydroida collected during the exploration of the Gulf Stream and Gulf of Mexico by Alexander Agassiz, 1877-78. Bulletin of the Museum of Comparative Zoölogy at Harvard College 5:239252.

1882 New and interesting hydroids from Chesapeake Bay. Memoirs of the Boston Society of Natural History 3(4): 135-142.

1907 Reports on the scientific results of the expedition to the eastern tropical Pacific, in charge of Alexander Agassiz, by the U.S. Fish Commission steamer "Albatross", from October, 1904, to March, 1905, Licut.Commander L. M. Garrett, U.S.N., commanding. VIII. The hydroids. Memoirs of the Museum of Comparative Zoölogy at Harvard College 35(1):1-18.

COCKERELL, T. D. A.

1911 The nomenclature of the hydromedusae. Proceedings of the Biological Society of Washington 24:77-86.

CONGDON, E. D

1906 Notes on the morphology and development of two species of Eudendrium. Biological Bulletin 11:2746.

1907 The hydroids of Bermuda. Proceedings of the American Acadeny of Arts and Sciences 42:463-485.

COOKE, W. J.

1975 Shallow water hydroids from Enewetak Atoll, Marshall Islands. Micronesica 11:85-108.

1977 Order Hydroida. In Devaney, D. M. and L. G. Eldredge, eds., Reef and shore fauna of Hawaii. Section I: Protozoa through Ctenophora. Bernice P. Bishop Museum Special Publication 64:71-74.

COPE, E. D

1884 On the fishes of the Recent and Pliocene lakes of the western part of the Great Basin, and of the Idaho Pliocene lake. Proceedings of the Academy of Natural Sciences of Philadelphia 35:134-166.

CORNELIUS, P. F. S

1975 A revision of the species of Lafoeidac and Haleciidae (Coclenterata: Hydroida) recorded from Britain and nearby seas. Bulletin of the British Museum (Natural History), Zoology 28:375-426.

1976 Proposed validation of Halecium Oken. 1815 (Coelenterata: Hydroida), and suppression of Thoa Lamouroux, 1816 (Hydroida), under the plenary powers. Bulletin of Zoological Nomenclature 32:252-254.

1977 The linking of polyp and medusa stages in Obelia and other coclenterates. Biological Journal of the Linnean Society 9:45-57.

1981 Life cycle, dispersal and distribution among the Hydroida. Porcupine Newsletter 2:47-50.

CORNELIUS, P. F. S. and J. B. GARFATI

1980 The coelenterate taxa of Joshua Alder. Bulletin of the British Museum (Natural History), Zoology 39:273291. 
COSTA, O. G

1839 Catalogo de zoofiti dell 'una e l'altra Sicilia. Corrispondenza Zoologica 1:185-189.

1841 Note sur l'appareil vasculaire de la velelle (Armenistarium velella). Annales des Sciences Naturelles, Zoologie 16:187-189.

1842 Fauna del regno di Napoli. Zoofiti. Genere Anisocalice; Anisocalyx, Don. Napoli, Azzolino. 24 pp.

COWARD, W. E.

1909 On Ptilocodium repens a new gymnoblastic hydroid epizoic on a pennatulid. Koninklijke Akademic van Wetenschappen te Amsterdam, Verslag van de Gewone Vergaderingen der Wis-En Natuurkundige Afdeeling 17:729-735.

COWDEN, R. R.

1964 A cytochemical study of gonophore and oocyte development in Pennaria tiarella. Acta Embryologiae et Morphologiae Experimentalis 7:167-179.

1965a A cytological and cytochemical study of hydranths of the hydroid coelenterate. Pennaria tiarella. Zeitschrift für Zellforschung und Mikroskopische Anatomic 65:869-883.

1965b Cytochemical studies of embryonic development to metamorphosis in the gymnoblastic hydroid, Pennaria tiarella. Acta Embryologiae et Morphologiae Experimentalis 8:221-231.

CRANCH, J.

1818 A general notice of the animals. In Tuckey, J. K., Narrative of an expedition to explore the River Zaire. usually called the Congo, in South Africa, in 1816. London. John Murray, pp. 407-419.

CROWELL, S.

1947 A new form of the hydroid Stylactis. Biological Bulletin 93:206.

CUVIER, G.

1798 Tableau élémentaire de l'histoire naturelle des animaux. Paris, Baudouin. 710 pp.

DALYELL, J. G

1847 Rare and remarkable animals of Scotland, represented from living subjects: with practical observations on their nature. Vol. 1. London, John van Voorst. 270 pp.

DAMAS, $\mathrm{H}$.

1936 Une méduse aberrante Oonautes hanseni (n.g., n.sp.). Mémoires de la Société Royale des Sciences de Liège, 4 me série, 1:43-62.

DANA, J. D

1848 United States Exploring Expedition. During the years $1838,1839,1840,1841,1842$. Under the command of Charles Wilkes, U.S.N. Zoophytes. Philadelphia. Lea and Blanchard. $740 \mathrm{pp}$.

DANIEL, R.

1976 Chondrophora of the Indian Ocean. Journal of the Marine Biological Association of India 18:110-121. DANIEL, R. and A. DANIEL

1963 On the siphonophores of the Bay of Bengal. 1. Madras coast. Journal of the Marine Biological Association of India 5:185-220.
DELAGE, Y. and E. HÉROUARD

1901 Traité de zoologie concrète. Tome 2, 2ne partie. Paris. Librairie C. Reinwald. 848 pp.

DELSMAN, H. C.

1923 Beiträge zur Entwickelungsgeschichte von Porpita Treubia 3:243-266.

DOLLFUS, R. P.

1936 Polypiers (hexacoralliaires et hydrocoralliaires) récoltés à la Guadeloupe par la mission cryptoganique du muséum en 1936. Bulletin du Muséum National d'Histoire Naturelle. 2me séric, 8:514-515.

DONS, C

1913 Hydroid-Bemerkungen. 1. Rhizogeton nudus Broch und Halecium curvicaule Lorenz neu für die Fauna Norwegens. Tromsø Museums Aarshefter 34:51-70.

DUCHASSAING, P

1850 Animaux radiaires des Antilles. Paris, Baillière et Fils. $33 \mathrm{pp}$.

DUCHASSAING. P. and J. MICHELOTTI

1860 Mémoire sur les coralliaires des Antilles. Mémoires de l'Académie des Sciences de Turin, série 2, 19:1-89.

1864 Supplément au mémoire sur les coralliaires des Antilles. Mémoires de l'Académie des Sciences de Turin. série 2, 23:1-112.

DUJARDIN, F.

1843a Observations sur un nouveau genre de médusaires, provenant de la métamorphose des syncorynes. Comptes Rendus Hebdomadaires des Séances de l'Académie des Sciences 16:1132-1136.

1843 b Observations sur un nouveau genre de médusaires, provenant de la métamorphose des syncorynes. Annales des Sciences Naturelles, Zoologie et Biologie Animale, 2de série, 20:370-373.

EDWARDS. C,

1964a On the hydroids and medusae Bougaimillia pyramidata and B. muscoides. Journal of the Marine Biological Association of the United Kingdom 44:725752.

1964b The hydroid of the anthomedusa Bougainvillia britannica. Journal of the Marine Biological Association of the United Kingdom 44:1-10.

1966a The hydroid and the medusa Bougainvillia principis. and a review of the British species of Borgainvillia. Journal of the Marine Biological Association of the United Kingdom 46:129-152.

1966b Velella velella (L.): the distribution of its dimorphic forms in the Atlantic Ocean and the Mediterranean. with comments on its nature and affinities. In Barnes, H., ed., Some contemporary studies in marine science, 1966. London, George Allen and Unwin, pp 283-296.

1972 The hydroids and the medusac Podocoryne areolata, $P$. borealis and $P$. camea. Journal of the Marine Biological Association of the United Kingdom 52:97144.

1978 The hydroids and medusac Sarsia occulta sp. nov. Sarsia tubulosa and Sarsia loveni. Joumal of the Ma- 
rine Biological Association of the United Kingdom 58:291-311.

1983 The hydroids and medusac Sarsia piriforma sp. nov. and Sarsia striata sp. nov. from the west coast of Scotland, with observations on other species. Journal of the Marine Biological Association of the United Kingdom 63:49-60.

EDWARDS, C. and S. M. HARVEY

1983 Observations on the hydroids Conve pintneri and Thecocodium brieni new to the British coast. Journal of the Marine Biological Association of the United Kingdom 63:37-47.

EIIRENBERG, C. G.

1834 Beiträge zur physiologischen Kenntniss der Corallenthiere im allgemeinen, und besonders des rothen Mecres, nebst cinem Versuche zur physiologischen Systematik derselben. Abhandlung der Königlichen Akademic der Wissenschaften, Berlin 1:225-380.

EKMAN, S

1953 Zoogcography of the sea. London, Sidgwick and Jackson. 417 pp.

ESCHSCHOLTZ. F

1825 Bericht über dic zoologische Ausbeute während der Reise von Kronstadt bis St. Peter und Paul. Isis von Oken 1825:733-747.

1829 System der Acalephen. Einc ausfürliche Beschrcibung aller medusenartigen Strahlticre. Berlin, Ferdinand Dümmler. $190 \mathrm{pp}$

ESPER, E. J. C

1790 Die Pflanzenthiere in Abbildungen nach der Natur mit Farben erleuchtet. 1. Theil. Nürnberg, Kaspischen Buchhandlung. $320 \mathrm{pp}$

FEWKES, J. W

1881 Studies of the jelly-fishes of Narragansett Bay. Bulletin of the Muscum of Comparative Zoölogy at Harvard College 8:141-182.

1882 On the Acalephae of the east coast of New England. Bulletin of the Museum of Comparative Zoölogy at Harvard College 9:291-310.

1883 Exploration of the surface fauna of the Gulf Stream, under the auspices of the United States Coast Survey, by Alexander Agassiz. IV. On a few medusac from the Bermudas. Bulletin of the Museum of Comparative Zoölogy at Harvard College 11:79-90.

1887 A hydroid parasitic on a fish. Nature 36:604-605.

1889 New invertebrata from the coast of California. Bullctin of the Essex Institute 21:99-146.

1891 An aid to a collector of the Coclenterata and Echinodermata of New England. Bulletin of the Essex Institute 23:1-91.

FIELDS, W. G. and G. O. MACKIE

1971 Evolution of the Chondrophora: evidence from behavioural studies on Velella. Journal of the Fisheries Research Board of Canada 28:1595-1602.

FILIPPI, F. de

1866 Sopra due idrozoi del Mediterranco. Memoric della Reale Accademia delle Scienze di Torino 23:375385.
FISCIIER VON WAIDHEIM G

1823 Enchiridion generum animalium. Moscow. $32 \mathrm{pp}$

FLEMING,

1828 A history of British animals, exhibiting the descriptive characters and systematical arrangement of the genera and species of quadrupeds, birds, reptiles, fishes, Mollusca, and Radiata of the United Kingdom. Edinburgh, Bell and Bradfute. $565 \mathrm{pp}$

FLOREZ GONZALEZ. L

1983 Inventario preliminar de la fauna hydroide de la Bahia de Cartagena y arcas adyacentes. Bogota, Boletín del Museo del Mar 11:112-140.

FORBES, E.

1841 Contributions to British actinology. Annals and Magazine of Natural History 7:81-85

1846 On the pulmograde medusac of the British seas. Annals and Magazine of Natural History 18:284-287.

1848 A monograph of the British naked-eyed medusac: with figures of all the species. London, Ray Society. 104 $\mathrm{pp}$

FORBES, E. and J. GOODSIR

1851 On some remarkable marine invertebrata new to the British seas. Transactions of the Royal Society of Edinburgh 20:307-315.

FORSKÅL, P.

1775 Descriptiones animalium avium, amphibiorum, piscium, insectorum, vermium; quac in itincre orientali observavit Petrus Forskål. post mortem auctoris edidit Carsten Niebuhr. Hauniac, Mölleri. 164 pp.

1776 Icones rerum naturalium, quas in itinere orientali depingi curavit Petrus Forskål. Post mortem auctoris ad regis mandatum acri incisas edidit Carsten Nicbuhr. Hauniae, Mölleri. 15 pp.

FRASER, C. M.

1912 Some hydroids of Beaufort, North Carolina. Bulletin of the United States Bureau of Fisheries 30:339-387.

1914 Some hydroids of the Vancouver Island region. Transactions of the Royal Socicty of Canada, 3rd series, Section 4, 8:99-216.

1937 Hydroids of the Pacific coast of Canada and the United States. Toronto, University of Toronto Press. 207 pp.

1938 Hydroids of the 1934 Allan Hancock Pacific Expcdition. Allan Hancock Pacific Expeditions 4:1-105.

1943a Relationship in North American families of gymnoblastic hydroids. Proccedings and Transactions of the Royal Socicty of Canada, 3rd series, Section 5, 37: 29-33.

1943b Distribution records of some hydroids in the collection of the Museum of Comparative Zoölogy at Harvard College, with description of new genera and new species. Proceedings of the New England Zoölogical Club 22:75-98.

1944 Hydroids of the Atlantic coast of North America. Toronto, University of Toronto Press. $451 \mathrm{pp}$.

1946 Distribution and relationship in American hydroids. Toronto, University of Toronto Press. 464 pp.

1948 Hydroids of the Allan Hancock Pacific Expeditions since March, 1938. Allan Hancock Pacific Expeditions 4:179-335. 
FREY, $H$, and R. LEUCKART

1847 Beiträge zur Kenntniss wirbelloser Thiere mit besonderer Berücksichtigung der Fauna des norddeutschen Meeres. Braunschweig, Verlag von Friedrich Vicweg und Sohn. $170 \mathrm{pp}$.

GAERTNER, $J$.

1774 In Pallas, P. S., Spicilcga zoologica quibus novae imprimus et obscurae animalium species. Fasc. 10. Berolini, August Lange. 41 pp.

GARCIA-CORRALES, P. and A. AGUIRRE

1985 La especie Halocordyle disticha (Goldfuss, 1820), y sus sinonimias. Boletín del Instituto Español de Oceanografia 2:85-96.

GARSTANG, w.

1894 Faunistic notes at Plymouth during 1893-94. With observations on the breeding seasons of marine animals, and on the periodic changes of the floating fauna. Journal of the Marine Biological Association of the United Kingdom, n.s., 3:210-235.

1946 The morphology and relations of the Siphonophora. Quarterly Journal of Microscopical Science 87:103193.

GEGENBAUR, C.

1857 Versuch eines Systemes der Medusen, mit Beschreibung neuer oder wenig gekannter Formen; zugleich ein Beitrag zur Kenntniss der Fauna des Mittelmeeres. Zeitschrift für Wissenschaftliche Zoologie 8:202-273.

GEISELMAN, J. A.

1977 Marine colonial hydroid inclusion discovered within planktonic Oscillatoria colonies. Bulletin of Marine Science 27:821-824.

GMELIN, J. F.

1790 Caroli a Linné, systema naturae per regna tria naturae, secundum classes, ordines, gencra, species, cum characteribus, differentiis, synonymis, locis. Editio decima tertia, aucta reformata. Tomus 1, Pars 6. Lipsiae, pp. 3021-4120.

GOETTE, A.

1916 Die Gattungen Podocoryne, Stylactis und Hydractinia. Zoologische Jahrbücher, Abteilung für Systematik, Geographie und Biologie der Tiere 39:443510.

GOLDFUSS, G. A.

1818 Ueber die Classification der Zoophyten. Isis 1818: 1008-1013.

1820 Handbuch der Zoologie. I. Abtheilung. Nürnberg, Johann Leonhard Schrag. 696 pp.

GOSSE, P. H.

1853 A naturalist's rambles on the Devonshire coast. London, John van Voorst. 451 pp.

GOY, J.

1972 Les hydroméduses de la mer Ligure. Bulletin du Muséum National d'Histoire Naturelle, série 3, no. 83, Zoologie 62:965-1008.

GRAEFFE, E.

1883 Biologische Notizen über Seethiere der Adria. Bollettino della Socictà Adriatica di Scienze Naturali in Tricste 8:79-89.
GRAVELY, F, H

1927 The littoral fauna of Krusadai Island in the Gulf of Manaar. Hydrozoa. Bulletin of the Madras Government Muscum, n.s., Natural History, 1:7-20.

GRAY, J. E.

1847 An outline of an arrangement of stony corals. Annals and Magazine of Natural History 19:120-128.

GRÖNBERG, G.

1897 Beiträge zur Kenntniss der Gattung Tubularia. Zoologische Jahrbücher, Abtheilung für Anatomie und Ontogenie der Thiere 11:61-76.

GUILDING, L.

1828 Observations on the zoology of the Caribacan Islands. Zoological Journal 3:403-408.

IIAAN, W. de

1827 Verhandeling over de Rangschikking der Velellen, Porpiten en Physalien. Bijdragen tot de Natuurkundige Wetenschappen 2:489-503.

HAECKEL, E

1864 Beschreibung neuer craspedoter Medusen aus dem Golfe von Nizza. Jenaische Zeitschrift für Medicin und Naturwissenschaft 1:325-342.

1879 Das System der Medusen. Erster Theil einer Monographie der Medusen. Denkschriften der MedicinischNaturwissenschaftlichen Gesellschaft zu Jena 1. 360 pp.

1888a System der Siphonophoren auf phylogenetischer Grundlage entworfen. Jenaische Zeitschrift für Naturwissenschaft 22:1-46.

1888b Report on the Siphonophorae. Report on the Scientific Results of the Voyage of H.M.S. Challenger During the Years 1873-1876, Zoology, 28:1-380.

1889 Report on the deep-sea Keratosa collected by H.M.S. Challenger during the years 1873-76. Report on the Scientific Results of the Voyage of H.M.S. Challenger During the Years 1873-1876, Zoology, 32: $1-92$.

HARGITT, C. W.

1900 A contribution to the natural history and development of Pennaria tiarella McCrady. American Naturalist 34:387-416.

1901 a Synopses of North-American invertebrates. XIV. The Hydromedusae-Part 1. American Naturalist 35:301315.

1901 b Synopses of North-American invertebrates. XIV. The Hydromedusac-Part 111. American Naturalist 35:575-595

1902 Notes on a few medusae new to Woods Holl. Biological Bulletin 4:13-23.

1904a Notes on some hydromedusae from the Bay of Naples. Mitteilungen aus der Zoologischen Station zu Neapel 16:553-585

1904b The medusac of the Woods Hole region. Bulletin of the United States Bureau of Fisheries 24:23-79.

1908 Notes on a few coelenterates of Woods Holl. Biological Bulletin 14:95-120.

1924 Hydroids of the Philippine Islands. Philippine Journal of Science 24:467-507. 
HARTLAUB, C

1897 Die Hydromedusen Helgolands. Zweiter Bericht. Wissenschaftliche Mecresuntersuchungen, n.F., 2: 449-537

1905 Die Hydroiden der magalhaensischen Region und chilenischen Küste. Zoologische Jahrbücher, Supplement-Band 6:497-714.

1907 Craspedote Medusen. I. Teil. I. Lief.: Codoniden und Cladonemiden. Nordisches Plankton, aus Lief. 6, 12:1135.

1911 Craspedote Medusen. I. Teil. 2. Lief.: Familie III Margelidae. Nordisches Plankton, aus Lief. 15, 12:137235.

1914 Craspedote Medusen. 1. Teil. 3. Lief.: Familie IV Tiaridae. Nordisches Plankton, aus Lief. 17, 12:237363.

1918 Craspedote Medusen. I. Teil. 4. Lief.: Familie V Wi]liadae. Nordisches Plankton, aus Lief. 19. 12:365479.

HICKSON, S. J.

1898a On the species of the genus Millepora: a preliminary communication. Proceedings of the Zoological Society of London 1898:246-257.

1898b Notes on the collection of specimens of the genus Millepora obtained by Mr. Stanley Gardiner at Funafuti and Rotuma. Proceedings of the Zoological Society of London 1898:828-833.

IHINCKS, T.

1862 On the production of similar gonozooids by hydroid polypes belonging to different genera. Annals and Magazine of Natural History, 3rd series, 10:459-461.

1868 A history of the British hydroid zoophytes. London, John van Voorst. $338 \mathrm{pp}$.

187I Supplement to a "Catalogue of the zoophytes of South Devon and South Cornwall", with descriptions of new species. Annals and Magazine of Natural History, 4th series, 8:73-83.

IIIRAI. E.

1958 On the species of Cladonema radiatum var. maveri Perkins. Bulletin of the Marine Biological Station of Asamushi 9:23-25

IIIRO, F

1939 Notes on the animals found on Macrocheira kuempferi de Haan. 111. Hydroids. Annotationes Zoologicae Japonenses 18:167-176.

IIIROIITO, EMPEROR OF JAPAN

1977 Five hydroid species from the Gulf of Aqaba, Red Sea. Tokyo, Biological Laboratory, Imperial Household. $26 \mathrm{pp}$.

HODGE, G.

1861 On a new hydroid zoophyte (Podocoryne alderi). Transactions of the Tyneside Naturalists Field Club 5:82-84.

IIUXLEY, T. H.

1859 The oceanic Hydrozoa; a description of the Calycophoridae and Physophoridac observed during the voyage of H.M.S. "Rattlesnake" in the years 1846-1850. London, Ray Society. 143 pp.
IIYMAN, L. II

1947 Two new hydromedusae from the California coast. Transactions of the American Microscopical Society $66: 262-268$.

INTERNATIONAL, COMMISSION ON ZOOLOGICAL, NONIENCLATURE

1985 International code of zoological nomenclature. Third edition. Adopted by the XX General Assembly of the International Union of Biological Sciences. Berkeley. University of California Press. 338 pp.

IWASA, M

1934 Revision of Stylactis and its allied genera, with description of Stylactella (Stylactis) yerii n.sp. Journal of the Faculty of Science. Hokkaido Imperial University, series $6,2: 241-277$.

JAIDERIIOLM, F.

1902 Die Hydroiden der schwedischen zoologischen Polarexpedition 1900. Bihang till Kungliga Svenska Vetenskaps-Akademiens Handlingar 28, Afd. 4, 12: I-11.

1909 Northern and Aretic invertebrates in the collection of the Swedish State Museum (Riksmuseum). IV. Hydroiden. Kungliga Svenska Vetenskapsakademiens Handlingar, Ny Följd, 45:1-124

1919 Zur Kenntnis der Hydroidenfauna Japans. Arkiv för Zoologi 12(9):1-34.

1920 On some exotic hydroids in the Swedish Zoological State Museum. Arkiv för Zoologi 13(3):1-11.

JARVIS, F. E

1922 The hydroids from the Chagos, Seychelles and other islands and from the coasts of British East Africa and Zanzibar. Transactions of the Linnean Society of London (Zoology) 18:331-360.

JOHANSEN, A C. and J. C. L. LEVINSEN

1903 De danske farvandes plankton i aarene 1898-1901. Coelenterater, chactognather, annelider, pteropoder. appendicularier. Det Kongelige Danske Videnskabernes Selskabs Skrifter. 6 Rackke. 12:273-297.

JOHNSTON, G.

1836 A catalogue of the zoophytes of Berwickshire. Berwickshire Naturalist's Club Proceedings 1:107-108.

1838 A history of the British zoophytes. Edinburgh, W. H. Lizars. 341 pp.

KEFERSTEIN, W

1863 Untersuchungen über niedere Seethicre. Zeitschrift für Wissenschaftliche Zoologie 12:1-147.

KIRKPATRICK, P. A. and P. R. PUGII

1984 A synopsis of the siphonophores and velellids. Synopses of the British Fauna, n.s., Leiden, E. J. Brill, vol. 29. $154 \mathrm{pp}$.

KIRKPATRICK, R.

1890 Reports on the zoological collections made in Torres Straits by Professor A. C. Haddon, 1888-1889. Hydroida and Polyzoa. Proceedings of the Royal Dublin Socicty, n.s., 6:603-626.

1910 Hydrozoa and Porifera. In Cunningham, J. T., On the marine fishes and invertebrates of St. Helena. 
Proceedings of the Zoological Society of London 1910:86-131.

KÖLLIKER, A.

1853 Die Schwimmpolypen oder Siphonophoren von Messina. Leipzig, Wilhelm Engelmann. 96 pp.

KOMAI, T.

1931 On the hydroid stage of Cytaeis japonica Uchida. Annotationes Zoologicae Japonenses 13:255-258.

1932 On two species of athecate hydroids associated with scorpaenoid fishes. Annotationes Zoologicae Japonenses 13:445-459.

KRAMP, P. L.

1921 Kinetocodium danae n.g., n.sp. a new gymnoblastic hydroid, parasitic on a pteropod. Videnskabelige Meddelelser fra Dansk Naturhistorisk Forening i København 74:1-21.

1928 Papers from Dr. Th. Mortensen's Pacific Expedition 1914-16. XLIII. Hydromedusae 1. Anthomedusae. Videnskabelige Meddelelser fra Dansk Naturhistorisk Forening i Kjøbenhavn 85:27-64.

1932 The Godthaab Expedition 1928. Hydroids. Meddelelser om Grønland 79(1): 1-86.

1933 The Scoresby Sound Committee's 2nd East Greenland Expedition in 1932 to King Christian IX's Land. Coelenterata, Ctenophora and Chaetognatha. Meddelelser om Grønland 104(11):1-20.

1935 Corydendrium dispar, a new athecate hydroid from Scandinavian seas, with remarks on classification. Göteborgs K. Vetenskaps-och Vitterhets-samhälles Handlingar, Serien B, 4(11):1-15.

1937 Polypdyr (Coelenterata). Il. Gopler. Danmarks Fauna 43:1-223.

1939 Occasional notes on Coelenterata. 111. Videnskabelige Meddelelser fra Dansk Naturhistorisk Forening i Kjøbenhavn 103:503-516.

1943 The zoology of east Greenland. Hydroida. Meddelelser om Grønland 121(11):1-52.

1949 Origin of the hydroid family Corymorphidae. Videnskabelige Meddelelser fra Dansk Naturhistorisk Forening i Kjøbenhavn 111:183-215.

1957 Hydromedusae from the Discovery collections. Discovery Reports 29:1-128.

1959 The hydromedusae of the Atlantic Ocean and adjacent waters. Dana-Report 46:1-283.

1961 Synopsis of the medusae of the world. Journal of the Marine Biological Association of the United Kingdom 40: $1-469$.

1965 The hydromedusae of the Pacific and Indian oceans. Dana-Report 63:1-162.

1968 The hydromedusac of the Pacific and Indian oceans. Sections II and III. Dana-Report 72:1-200.

KRAMP, P. L. and D. DAMAS

1925 Les méduses de la Norvège. Introduction et partic spéciale. 1. Videnskabelige Meddelelser fra Dansk Naturhistorisk Forening i Kjøbenhavn 80:217-324

KROHN, A

1853a Über die Brut des Cladonema radiatum und deren Entwicklung zum Stauridium. Müllers Archiv für Anatomie und Physiologie 1853:420-426. 1853b Ueber die Natur des kuppelförmigen Anhanges am Leibe von Phyllirhoë bucephalum. Archiv für Naturgeschichte 19(1):278-281.

KÜHN, A.

1913 Entwicklungsgeschichte und Verwandtschaftsbeziehungen der Hydrozoen. 1. Teil: Die Hydroiden. Ergebnisse und Fortschritte der Zoologie 4:1-284.

LAMARCK, J. B. P. A. de M

1801 Systême des animaux sans vertèbres, ou tableau général des classes, des ordres et des genres de ces animaux. Paris. $432 \mathrm{pp}$.

1816 Histoire naturelle des animaux sans vertèbres. Tome 2. Paris. 568 pp.

LAMOUROUX, J. V. F.

1812 Extrait d'un mémoire sur la classification des polypiers coralligènes non entièrement pierreux. Nouveau Bulletin des Sciences, par la Société Philomatique de Paris 3:181-188.

1816 Histoire des polypiers coralligènes flexibles, vulgairement nommés zoophytes. Caen, F. Poisson. 560 pp.

LARSON, R. J.

1980 The medusa of Velella velella (Linnaeus, 1758) (Hydrozoa, Chondrophorae). Journal of Plankton Research 2:183-186.

1982 Life history of the hydromedusa Stomotoca pterophylla Haeckel and its ichthyoparasitic hydroid. In Rützler, K. and I. G. Macintyre, eds., The Atlantic barrier reef ecosystem at Carrie Bow Cay, Belize, I. Structure and communities. Washington, Smithsonian Institution Press, 433-439.

LEIDY, J.

1855 Contributions towards a knowledge of the marine invertebrate fauna, of the coasts of Rhode Island and New Jersey. Journal of the Academy of Natural Sciences of Philadelphia, 2nd series, 3:135-152.

LELOUP, $\mathrm{E}$.

1929 Recherches sur l'anatomie et le développement de Velella spirans Forsk. Archives de Biologie 39:397478.

1932 Une collection d'hydropolypes appartenant à l'Indian Museum de Calcutta. Records of the Indian Museum $34: 131-170$.

1937 Hydropolypes et scyphopolypes recueillis par C. Dawydoff sur les côtes de l'Indochine Française. Mémoires du Musée Royal d'Histoire Naturelle de Belgique, 2me série, 12:1-73.

1954 À propos des siphonophores. Volume Jubilaire Victor van Strachlen 2:643-699.

LEMCHE, $\mathrm{H}$

1976 Comment on the proposed validation of Halecium Oken, 1815. Z. N. (S.) 2116. Bulletin of Zoological Nomenclature 33:72.

LENDENFELD, R. von

1885a The Australian hydromedusac. Part I. The classification of the Hydromedusae. Proceedings of the Linnean Society of New South Wales 9:206-241.

1885b The Australian Hydromedusae. Part V. The Hydromedusinae, Hydrocorallinac and Trachymedusac. 
Proceedings of the Linnean Society of New South Wales 9:581-612.

LENGLRICII, II.

1922 Zur systematischen Auflassung der Eleutheriiden. Zoologischer Anzeiger 54:209-215.

LE PELLTIER de SAINT-FARGEAU. A, and M. SERVILLE

1825 Entomologie, ou histoire naturelle des crustacés. des arachnides et des insectes. Encyclopédie Méthodique, Tone 10.

LESII-I,AURIE. G. E.

1976 Stolon vs. hydranth determination in Pennaria tiarella planulae: a role for DNA synthesis. In Mackic, G. O. ed. Coelenterate ecology and behavior. New York. Plenum Press, pp. 365-375.

L.ESSON, R. P.

1826 Voyage autour du monde, exécuté par l'ordre du Roi. sur la corvette de sa majesté. "la Coquille", pendant les années $1822,1823,1824$ et 1825. Histoire naturelle, zoologie. Atlas. Zoophytes. Paris, A. Bertrand. $16 \mathrm{pl}$.

1830 Voyage autour du monde, pendant les années 1822, 1823, 1824 et 1825. Zoologie. Description des zoophytes échinodermes. Voyage de la Coquille II, II, 20. $155 \mathrm{pp}$.

1836 Mémoire sur la famille des béroïdes (Beroideae Less.). Annales des Sciences Naturelles, 2de série. Zoologie 5:235-266.

1843 Histoire naturelle des zoophytes. Acalèphes. Paris, Librairie Encyclopédique de Roret. 596 pp.

LEUCKART, R

1856 Beiträge zur Kenntniss der Medusenfauma von Nizza. Archiv für Naturgeschichte 22:1-40.

LLVINSEN. G. M. R

1893 Meduser. Ctenophorer og Hydroider fra Gronlands Vestkyst, tilligemed Bemaerkninger om Hydroidernes Systematik. Videnskabelige Meddelelser fra Dansk Naturhistorisk Forening i Kjobenhavn 5: 143-220.

L.IGIT, S. I:

1913 The morphology of Eudendrium griffini sp. nov. Philippine Journal of Science (D), 8:333-356.

LINNAEUS, C.

1758 Systema naturae per regna tria naturae, secundum classes, ordines, genera, species cum characteribus, differentiis, synonymis, locis. Editio decima, reformata. Holmiae, Laurentii Salvii. $823 \mathrm{pp}$.

1761 Fauna suecica sistens animalia sueciac regni: Mammalia, Aves, Amphibia, Pisces, Insecta, Vermes. Distributa per classes \& ordines, genera \& species. cum differentiis specierum, synonymis auctorum, nominibus incolarum, locis natalium, descriptionibus insectorum. Stockholmiae, Laurentii Salvii. 578 pp.

1767 Systema naturae per regna tria naturae, secundum classes, ordines, genera, specics, cum characteribus, differentiis, synonymis, locis. Tomus I. Pars 1l. Editio duodecima, reformata. Holmiae, Laurentii Salvii, pp. $533-1317$.

LO BIANCO, S

1909 Notizic biologiche riguardanti specialmente il periodo di maturità sessuale degli animali del Golfo di Napoli.
Mittheilungen aus der Zoologischen Station zu Neapel 19:513-763.

IÜTKEN, C

1850 Nogle Bemaerkninger om Medusernes systematiske Inddeling. navnlig med Hensyn til Forbes's History of Brittish naked-eyed medusac. Videnskabelige Meddelelser fra den Naturhistoriske Forening i Kjöbenhavn 1850:15-35.

MCCRADY, J.

1859a Gymnopthalmata of Charleston Harbor. Proccedings of the Elliott Society of Natural History 1:103-221.

1859b Description of Oceania (Turritopsis) mutricula nov. spec. and the embryological history of a singular medusan larva, found in the cavity of its bell. Proceedings of the Elliott Society of Natural History 1:5590 .

MCDOUGALL, K. D

1943 Sessile marine invertebrates of Beaufort. North Carolina. Ecological Monographs 13:321-374.

MAAS, O

1905 Bemerkungen zum System der Medusen. Revision der Cannotiden Hacekels. Sitzungsberichte der Mathematisch-Physikalischen Klasse der Königlich Bayerischen Akidemie der Wissenschaften zu München 34:421-445.

1911 Beiträge zur Naturgeschichte Ostasiens. Herausgegeben von Dr. F. Dollein. Japanische Medusen. Abhandlungen der Mathematisch-Physikalischen Klasse der Königlich Bayerischen Akademie der Wissenschaften, Supplement-Band 1(8):1-52.

MACKIE. G. O

1959 The evolution of Chondrophora (Siphonophora-Disconanthac): new evidence from behavioural studies. Transactions of the Royal Society of Canada 53:720.

1960 The structure of the nervous system in Velella. Quarterly Journal of Microscopical Science 101:119-131.

NAMNIEN, T. A.

1963 On a collection of hydroids from south India. I. Suborder Athecata. Journal of the Marine Biological Association of India 5:27-61.

MARK, E. L.

1898 Preliminary report on Branchiocerianthus urceolus, a new type of actinian. Bulletin of the Museum of Comparative Zoölogy at Harvard College 32:147-154.

MARKTANNER-TURNLRETSCHER, G.

1890 Die Hydroiden des K. K. Naturhistorischen Hofmuseums. Annalen des K. K. Naturhistorischen Hofmuscums 5:195-286.

MARTIN, II. A

1904 Velella spiralis on the Cork coast. Jrish Naturalist 13(1):27.

MARTIN, R. and A. BRINCKMANN

1963 Zum Brutparasitismus von Phyllirrhoe bucephala Pér. \& Les. (Gastropoda. Nudibranchia) auf der Meduse Zanclea costata Gegenb. (Hydrozoa. Anthomedusae). Pubblicazioni della Stazione Zoologica di Napoli $33: 206-223$. 
MAYER, A. G.

1894 Cruise of the steam yacht "Wild Duck" in the Bahamas, January to April, 1893, in charge of Alexander Agassiz. III. An account of some medusae obtained in the Bahamas. Builetin of the Museun of Comparative Zoölogy at Harvard College 25:235-241.

1900a Descriptions of new and little-known medusae from the western Atlantic. Bulletin of the Museum of Conparative Zoölogy at Harvard College 37:1-9.

$1900 \mathrm{~b}$ Some medusae from the Tortugas, Florida. Bulletin of the Museum of Comparative Zoölogy at Harvard College 37:13-82.

1904 Medusae of the Bahamas. Museum of the Brooklyn Institute of Arts and Science, Memoirs of Natural Sciences, 1(1): 1-33.

1910 Medusae of the world. Vol. I. The Hydromedusae. Carnegie Institution of Washington, Publication 109:1230.

MERGNER, H. and E. WEDLER

1977 Über die Hydroidpolypenfauna des Roten Meeres und seiner Ausgänge. "Meteor" Forschungs-Ergebnisse D, 24:]-32.

MEYEN, F. J. F.

1834 Beiträge zur Zoologie, gesammelt auf einer Reise um die Erde. Fünfte Abhandlung. Über das Leuchten des Meeres und Beschreibung einiger Polypen und anderer niederer Tiere. Novorum Actorum Academiac Caesareae Leopoldino-Carolinae Naturae Curiosorum 16:125-216

MILLARD, N. A. H

1959a Hydrozoa from the coasts of Natal and Portuguese East Africa. Part Il. Gymnoblastea. Annals of the South African Museum 44:297-313.

1959 b Hydrozoa from ships hulls and experimental plates in Cape Town docks. Annals of the South African Museum 45:239-256

1966 The Hydrozoa of the south and west coasts of South Africa. Part Ill. The Gymnoblastea and small families of Calyptoblastea. Annals of the South African Museum 48:427-487.

1975 Monograph on the Hydroida of southern Africa. Annals of the South African Museum 68:1-513.

MILLARD, N. A. H. and J. BOUILLON

1973 Hydroids from the Seychelles (Coelenterata). Annales du Musée Royal de l'Afrique Centrale, série In- $8^{\circ}$. Sciences Zoologiques, 206:1-106.

1974 A collection of hydroids from Moçambique, East Africa. Annals of the South African Museum 65:140.

1975 Additional hydroids from the Seychelles. Annals of the South African Museum 69:1-15.

MHLNE EDWARDS, $H$.

1860 Histoire naturelle des coralliaires ou polypes proprement dits. Tome Troisième. Paris, Librairie Encyclopédique de Roret. 560 pp.

MHLNE EDWARDS, II. and J. IIAIME.

1849 Mémoire sur les polypiers appartenant aux groupes naturels des zoanthaires perforés et des zoanthaires tabulés. Comptes Rendus Hebdomadaires des Séances de l'Académie des Sciences 29:257-263.

MÖBIUS, $K$

1893 Über die Thiere der schleswig-holsteinischen Austernbänke, ihre physikalischen und biologischen Lebensverhältnisse. Sitzungsberichte der Königlich Preussischen Akademie der Wissenschaften zu Berlin 1893:67-92.

MODEER, A.

1790 Slägtet plättmask, Phyllidoce. Kongl. Vetenskaps Academiens Nya Handlingar 11:191-207.

1793 Inledning till kunskapen om maskkraken i allnänhet: 6 classen. Vaxtliknande maskkrak, Phytozoa. Kongl. Vetenskaps Academiens Nya Handlingar 14:243-260. MONTAGU, G

1815 An account of some new and rare marine British shells and animals. Transactions of the Linnean Society of London 11:179-204.

MOORE, H. B.

1949 The zooplankton of the upper waters of the Bermuda area of the North Atlantic. Bulletin of the Bingham Oceanographic Collection 12(2): I-97.

1969 Ecological guide to Bermuda inshore water. Bermuda Biological Station for Research, Special Publication $5: 1-25$

MORREN, C. F. A.

1828 Descriptio coralliorum fossilium in Belgio repertorum. Annales de l'Académie de Groningae 18271828: I-76.

MORRI, C.

1981 Idrozoi lagunari. Guide per il riconoscimento delle specie animali del acque lagunari e costiere italiane. Consiglio Nazionale delle Ricerche $\mathrm{AQ} / \mathrm{l} / 94,6: 1-105$.

MORRIS, B. F. and D. D. MOGELBERG

1973 Identification guide to the pelagic Sargassum fauna. Bermuda Biological Station for Research, Special Publication 11:1-63.

MOSELEY, H. N

1876 On the structure and relations of the alcyonarian Heliopora caerulea, with some account of the anatomy of a species of Sarcophyton, notes on the structure of species of the genera Millepora, Pocillopora, and Stylaster and remarks on the affinities of certain palaeozoic corals. Philosophical Transactions of the Royal Society of London 166:91-129.

1879 Notes by a naturalist on the "Challenger", being an account of various observaticns made during the voyage of H.M.S. "Challenger" round the world, in the years 1873-1876, under the commands of Capt. Sir G. S. Nares, R.N., K.C.B., F.R.S., and Capt. F. T. Thomson, R.N. London, MacMillan. 620 pp.

1880 Report on certain hydroid, alcyonarian, and madreporarian corals procured during the voyage of H.M.S Challenger, in the years 1873-1876. Report on the Scientific Results of the Voyage of H.M.S. Challenger During the Years 1873-76, Zoology, 2:1-248.

MOSI:R, I:

1925 Die Siphonophoren der Deutschen Südpolar-Expedition 1901-1903. Deutsche Südpolar-Expedition 1901-1903. 17(Zoologic 9): I-54 I. 
MOTZ-KOSSOWSKA, S

1905 Contribution à la connaissance des hydraires de la Méditerranée occidentale. I.-Hydraires gymnoblastiques. Archives de Zoologie Expérimentale et Générale, 4me série, 3:39-98.

MUELLER, P. L. S

1766 Deliciae naturae selectae, oder auserlesenes Naturalien-Kabinet..., ehemals herausgegeben von G. W. Knorr, und fortgesetzt von dessen Erben. 1. Theil. Nürnberg. $132 \mathrm{pp}$.

MÜLLER, O. F.

1776a Zoologiae Danicae prodromus, seu animalium Daniae et Norvegiae indigenarum characteres, nomina, et synonyma imprimis popularium. Hauniae, Hallageriis. $282 \mathrm{pp}$.

1776b Beschreibung zwoer Medusen. Beschäftigungen der Berlinischen Gesellschaft Naturforschender Freunde 2:290-297.

MURBACH, L.

1899 Hydroids from Woods Holl, Mass. Hypolytus peregrimus, a new unattached marine hydroid: Corynitis agassizii and its medusa. Quarterly Journal of Microscopical Science, n.s., 42:341-360.

NAIR, K. K.

1951 Medusae of the Trivandrum coast. Part I. Systematics. Bulletin of the Research Institute of the University of Travancore, Series C, Natural Science 2(1):47-75.

NAUMOV, D. V.

1960 Gidroidy i gidromeduzy morskikh, solonovatovodnykh i presnovodnykh basseinov SSSR. Akademiya Nauk SSSR, Opredeliteli po Faune SSSR 70:1-626.

NEAVE, S. A.

1939 Nomenclator zoologicus. A list of the names of genera and subgenera in zoology from the tenth edition of Linnaeus 1758 to the end of 1935. Vols. 1 and 2. London, Zoological Society of London, Vol. 1, 957 pp; Vol. 2, 1025 pp.

1940a Nomenclator zoologicus. A list of the names of genera and subgenera in zoology from the tenth edition of Linnaeus 1758 to the end of 1935 . Vol. 4. London, Zoological Society of London. $758 \mathrm{pp}$.

1940b Nomenclator zoologicus. A list of the names of genera and subgenera in zoology from the tenth edition of Linnaeus 1758 to the end of 1935. Vol. 3. London, Zoological Society of London. $1065 \mathrm{pp}$.

NELSON. R. G. and P. M. DUNCAN

1876 On the actinozoan nature of Millepora alcicormis, Dana and Linn. (pars). Annals and Magazine of Natural History, 4th series, 17:354-359.

NEPPI, $v$.

1917 Osservazioni sui polipi idroidi del Golfo di Napoli. Pubblicazioni della Stazione Zoologica di Napoli 2:2965 .

NORMAN, A. M

1865 On Merona, an undescribed genus of British Hydrozoa. Annals and Magazine of Natural History, 3rd series, 15:261-262.
NUTTING, C. C.

1901 The hydroids of the Woods Hole region. Bulletin of the United States Fish Commission 19:325-386.

1905 Hydroids of the Hawaiian lslands collected by the steamer Albatross in 1902. Bulletin of the United States Fish Commission for 1903:931-959.

OKEN. L

1815 Okens Lehrbuch der Naturgeschichte. III. Theil. Zoologie. Volume 1. Jena, Oken. 842 pp.

1817 lsis oder encyclopädische Zeitung von Oken. 146. Jena, pp. 1161-1168.

PALLAS, P. S.

1766 Elenchus zoophytorum sistens generum adumbrationes generaliores et specierum cognitarum succinctas descriptiones cum selectis auctorum synonymis. Hagae, Franciscum Varrentrapp. 451 pp.

PARR, A. E.

1939 Quantitative observations on the pelagic Sargassum vegetation of the western North Atlantic. Bulletin of the Bingham Oceanographic Collection 6(7): 1-94.

PENNINGTON, A. S.

1885 British zoophytes: an introduction to the Hydroida, Actinozoa, and Polyzoa found in Great Britain, Ireland, and the Channel 1slands. London, Reeve. 363 pp.

PENNYCUIK, P. R.

1959 Faunistic records from Queensland. Part V.-Marine and brackish water hydroids. Papers from the Department of Zoology, University of Queensland 1:141210 .

PERKINS, H. F

1902 Notes on the anatomy and histology of a new form of Cladonema from the Bahamas. Johns Hopkins University Circulars 21(155):25-27.

1906 Preliminary report of Henry F. Perkins. Carnegie Institution of Washington, Year Book 4:118-119.

1908 Notes on medusae of the western Atlantic. Papers from the Tortugas Laboratory of the Carnegie Institution of Washington 1:135-149.

PÉRON, F. and C. A. LESUEUR

1807 Voyage de découvertes aux terres australes exécuté par ordre de sa Majesté l'Empereur et Roi. Tableau général des planches qui composent l'atlas historique du voyage de découvertes aux terres australes. Paris, Imprimerie Impériale. 40 pls.

PETERSEN, K. W.

1979 Development of coloniality in Hydrozoa. In Larwood, G., and B. R. Rosen, eds., Biology and systematics of colonial animals. New York, Academic Press, pp. $105-139$.

PETERSEN, K. W. and M. VANNUCCI

1960 The life cycle of Koellikerina fasciculata (Anthomedusae, Bougainvilliidae). Pubblicazioni delle Stazione Zoologica di Napoli 31:473-492.

PICARD, J.

1951 Note sur les hydraires littoraux de Banyuls-sur-Mer. Vie et Milieu 2:338-349. 
1955 Les hydroïdes Pteronematidae origine des "Siphonophores" Chondrophoridae. Bulletin de I'Institut Océanographique de Monaco 1059:1-8.

1957 Études sur les hydrö̈des de la superfamille Pteronematoidea. I. Généralités. Bulletin de l'Institut Océanographique 1106:1-12.

1958 Origines et affinités de la faune d'hydropolypes (gymnoblastes et calyptoblastes) et d'hydroméduses (anthoméduses et leptoméduses) de la Méditerranćc. Rapport et Procès-Verbaux des Réunions, Commission Internationale pour l'Exploration Scientifique de la Mer Méditerranée 14:187-199.

PICTET, C.

1893 Étude sur les hydraires de la Baie d’Amboine. Revue Suisse de Zoologie 1:1-64

POCHE, $\mathrm{F}$

1914 Das System der Coelenterata. Archiv für Naturgeschichte 80 , Abteilung A, Heft 5:47-128.

POMEL, A.

1883 Classification méthodique et genera des échinides vivants et fossiles. Algiers. $120 \mathrm{pp}$

PRÉVOT, E.

1959 Morphologie et évolution des structures tentaculaires chez les hydraires gymnoblastes Capitata. Recueil des Travaux de la Station Marine d'Endoume 29:91-126.

QUATREFAGES, A. de

1842 Mémoire sur l'Eleutherie dichotome (Eleutheria dichotoma nob.) nouveau genre de Rayonnés, voisin des hydres. Annales des Sciences Naturelles, Zoologie, 2de série, 18:270-283.

QUELCH, J. J.

1886 Report on the reef-corals collected by H.M.S. Challenger during the years 1873-76. Report on the Scientific Results of the Voyage of H.M.S. Challenger During the Years 1873-76, Zoology, 16:1-203.

QUOY, J. R. C. and J. P. GAIMARD

1824 Voyage autour du monde, sur les corvettes...l'Uranic et la Physicienne, pendant les années 1817, 1818, 1819 et 1820 . Zoologie. Paris. Pillet Ainé. 712 pp.

RAFINESQUE, C. S

1820 Polypia. - The polyps. Annals of Nature, or Annual Synopsis of New Genera and Species of Animals, Plants, \&c Discovered in North America 1820:11.

RALPII, P. M

1953 A guide to the athecate (gymnoblastic) hydroids and medusae of New Zealand. Tuatara 5:59-75.

1959 The status and affinities of the anthomedusan Paragotoea bathybia Kramp, 1942. Procecdings of the Zoological Society of London 133:171-177.

RAI'P, W

1829 Untersuchungen über den Bau einiger Polypen des mittelländischen Meeres. Nova Acta Physico-Medica Academiae Caesareae Leopoldino-Carolinae Naturac Curiosorum 14:643-658.

RI:I:S, J. I

1979 The polyp and immature medusa stages of Cledonema californicum, Hyman, 1947 (Anthomedusac: Cladonemidae) with biological notes and a discussion of the taxonomy of the genus Cladonema. Journal of Natural History 13:295-302.

REES, w. J.

1936 On a new species of hydroid, Staurocoryne filiformis, with a revision of the genus Stauroconne Rotch, 1872. Journal of the Marine Biological Association of the United Kingdom 21:135-142.

1938 Observations on British and Norwegian hydroids and their medusac. Journal of the Marine Biological Association of the United Kingdom 23:1-42.

1949 On Cladonema myersi, a new species of hydroid from the Californian coast. Proceedings of the Zoological Socicty of London 1 19:861-865.

1953 Notes on Phyllirrhoe bucephala Péron and Lesueur and Mnestra parasites Krohn. Proceedings of the Malacological Society of London 29:219-221

1956a A revision of the hydroid genus Perigonimus M. Sars. 1846. Bulletin of the British Muscum (Natural History), Zoology 3:337-350.

1956b A revision of some northern gymnoblastic hydroids in the Zoological Museum, Oslo. Nytt Magasin for Zoologi 4:109-120.

1957 Evolutionary trends in the classification of .capitate hydroids and medusae. Bulletin of the British Museum (Natural History), Zoology 4:453-534.

1962 Hydroids of the family Cytaeidae L. Agassiz, 1862. Bulletin of the British Museum (Natural History), Zoology 8:381-400.

REES, W. J. and S. THUURSFIELD

1965 The hydroid collections of James Ritchie. Proceedings of the Royal Society of Edinburgh, Section B (Biology) 69:34-220.

RICE, W. N

1878 On the animal of Millepora alcicornis. American Journal of Science and Arts 116:180-182.

RIEDL, R

1963 Hydroidea-Polypengeneration (Hydropolypen). In Riedl, R., ed., Fauna und flora der Adria. Hamburg and Berlin, Paul Parey, pp. 124-133.

RISSO, A

1826 Histoire naturelle des principales productions de l'Europe méridionale et particulièrement de celles des en virons de Nice et des Alpes maritimes. Tome 5 me Paris, Levrault. 403 pp.

RITCHIE, J

1908 On collections of the Cape Verde Islands marine fauna. made by Cyril Crossland, M.A. (Cantab.), B.Sc (Lond.), F.Z.S., of St. Andrew's University, July to September, 1904. Proceedings of the Zoological Socicty of London 1907:488-514.

1909 Two unrecorded "Challenger" hydroids from the Bermudas, with a note on the synonymy of CampanIlaria insignis. Zoologist, 4th series, 13:260-263.

1910a The marine fauna of the Mergui Archipelago. Lower Burma, collected by Jas. J. Simpson, M.A., B.Sc. and R. N. Rudmose-Brown, D.Se., University of Aberdeen. February to May 1907. -The hydroids. 
Proceedings of the Zoological Society of London 1910:799-825.

1910b Hydroids from Christmas Island, Indian Ocean, collected by C. W. Andrews, D.Se., F.R.S., F.Z.S., in 1908. Proceedings of the Zoological Society of London 1910:826-836.

ROTCH. W. D

1872 On a new genus and species of hydroid zoophytes. Annals and Magazine of Natural History, 4th series, 10: $126-127$.

RUSSELL, F, S.

1953 The medusae of the British Isles. Anthomedusae, Leptomedusae, Limnomedusae, Trachymedusae and Narcomedusae. Cambridge, Cambridge University Press. $530 \mathrm{pp}$.

RUSSELL, F. S. and W. J. REES

1936 On rearing the hydroid Zanclea implexa (Alder) and its medusa Zanclea gemmosa McCrady, with a review of the genus Zanclea. Journal of the Marine Biological Association of the United Kingdom 21:107-130.

RYLAND. J.S

1974 Observations on some epibionts of gulf-weed, Sargassum natams (L.) Meyen. Journal of Experimental Marine Biology and Ecology 14:17-25.

SARS, G. O.

1874 Bidrag til kundskaben om norges Hydroider. Forhandlingen i Videnskabs-Selskabet i Christiania 1873:91150.

SARS, M.

1829 Bidrag til Söedyrenes Naturhistorie. Bergen, Chr. Dahl. 59 pp.

1835 Beskrivelser og lagttagelser over nogle macrkelige eller nye i Havet ved den Bergenske Kyst levende Dyr. Bergen, Thorstein Hallagers Forlag. $81 \mathrm{pp}$.

1846 Fauna littoralis Norvegiae oder Beschreibung und Abbildungen neuer oder wenig bekannten Seethiere, nebst Bcobachtungen über die Organisation, Lebensweise und Entwickelung derselben. Heft I. Christiania, Johann Dahl. 93 pp.

1857 Bidrag til kundskaben om Middelhavets Littoral-Fauna, Reisebemaerkninger fra Italien. Nyt Magazin for Naturvidenskaberne 9:110-164.

1874 Rhizorhagium roseum, M. Sars, n.gen. et sp. In Sars, G. O., Bidrag til kundskaben om norges Hydroider. Forhandlingen i Videnskabs-Selskabet i Christiania 1873:129.

1877 New and little known coelenterates. In Koren, J. and D. C. Danielssen, Fauna Littoralis Norvegiae. Part 3. Bergen, J. D. Beyer, pp. I-32.

SCHMIDT, $\mathrm{O}$.

1852 Hand-Atlas der vergleichenden Anatomie. Jena, Friedrich Mauke. 18 pp.

SCINEIDER, K. C.

1898a Hydropolypen von Rovigno, nebst Uebersicht über das System der Hydropolypen im Allgemeinen. Zoologische Jahrbücher, Abtheilung für Systematik, Geographie und Biologie der Thiere 10:472-555. 1898b Mitthcilungen über Siphonophoren. III. Systematische und andere Bemerkungen. Zoologischer Anzeiger 21:51-57, 73-95, 114-133, 153-173, 185200.

SCHOENHERR, C. J.

1823 Curculionides. Isis von Oken 1823, Heft 10:11321146.

SCHOMBURGK, R. H.

1847 The microscopical siliceous Polycystina of Barbados, and their relation to existing animals, as described in a lecture by Prof. Ehrenberg of Berlin, delivered before the Royal Academy of Sciences on the 14 February 1847. Annals and Magazine of Natural History $20: 115-127$

SCHWEIGGER, A. F.

1820 Handbuch der Naturgeschichte der skelettlosen ungegliederten Thiere. Leipzig. 776 pp.

SIGERFOOS, C. P.

1899 A new hydroid from Long Island Sound. American Naturalist 33:801-807.

SMALLWOOD. W. M.

1910 Notes on the hydroids and nudibranchs of Bermuda. Proceedings of the Zoological Society of London 1910:137-145.

SOLDANI. A.

1789 Testaceographiae ac zoophytographiae parvae et microscopicae. Tomus primus. Senis, Francisci Rossi. $80 \mathrm{pp}$.

SPAGNOLINI. A.

1871 Catalogo degli acalefi discofori del Golfo di Napoli. Atti della Società Italiana di Scienze Naturali 14:144223.

SPENCER, W. A.

1892 On the structure of Ceratella fusca (Gray). Transactions of the Royal Society of Victoria 2(2):8-24.

SPRACKLIN, B. W

1982 Hydroidea (Cnidaria: Hydrozoa) from Carrie Bow Cay, Belize. In Rützler, K., and 1. G. Macintyre, eds.. The Atlantic barrier reef ecosystem at Carrie Bow Cay. Belize, 1. Structure and communities. Smithsonian Contributions to the Marine Sciences 12:239251.

STECHOW, E.

1907 Neue japanische Athecata und Plumularidae aus der Sammlung Dr. Doflein. Zoologischer Anzeiger 32: 192-200.

1911 Beiträge zur Naturgeschichte Ostasiens. Herausgegeben von Dr. F. Doflein. Hydroidpolypen der japanischen Ostküste. I. Teil: Athecata und Plumularidae. Abhandlungen der Mathematisch-Physikalischen Klasse der Königlichen Bayerischen Akademie der Wissenschaften, Supplement-Band I(6): I-111.

1912 Hydroiden der Münchener Zoologisehen Staatssammlung. Zoologische Jahrbücher, Abteilung für Systematik, Geographie und Biologie der Tiere 32:333378.

1914 Zur Kenntnis neuer oder seltener Hydroidpolypen. meist Campanulariden, aus Amerika und Norwegen. Zoologischer Anzeiger 45:120-136. 
1919 Zur Kenntnis der Hydroidenfauna des Mittelmecres. Amerikas und anderer Gebiete, nebst Angaben über einige Kirchenpauer'sche Typen von Plumulariden. Zoologische Jahrbücher, Abtcilung für Systematik, Geographie und Biologie der Tiere 42:1-172.

1920 Neue Ergcbnisse auf dem Gebiete der Hydroidenforschung. Sitzungsberichte der Gesellschaft für Morphologie und Physiologie in München 31:9-45.

1921 a Neue Genera und Species von Hydrozoen und anderen Evertebraten. Archiv für Naturgeschichte 87:248-265.

1921 b Neue Gruppen skelettbildender Hydrozoen und Verwandtschaftsbeziehungen rezenter und fossiler Formen. Verhandlungen der Deutschen Zoologischen Gesellschaft 26:29-31.

1921e Neue Ergebnisse auf dem Gebiete der Hydroidenforschung Il. Münchener Medizinische Wochenschrift 68:30.

1922 Zur Systematik der Hydrozoen, Stromatoporen, Siphonophoren, Anthozoen und Ctenophoren. Archiv für Naturgeschichte 88:14]-155.

1923a Zur Kenntnis der Hydroidenfauna des Mittelmeeres, Amerikas und anderer Gebiete. II. Teil. Zoologische Jahrbücher, Abteilung für Systematik, Ökologie und Geographie der Tiere 47:29-270.

1923b Die Hydroidenfauna der Japanischen Region. Journal of the College of Science, Tokyo Imperial University $44(8): 1-23$.

STEENSTRUP, J. J. $S$.

1842 Om forplantning og udvikling gjennem vexlende generationsraekker, en saeregen form for opfostringen i de lavere dyrklasser. Kjøbenhavn, Bianco Lunos Bogtrykkeri. 76 pp.

1850 Sur Margelis principis. In Lütken, C., Nogle Bemaerkninger om Medusernes systematiske Inddeling, navnlig med Hensyn til Forbes's History of Brittish naked-eyed medusae. Videnskabelige Meddelelser fra den Naturhistoriske Forening i Kjöbenhavn 1850:35.

STEPHENS, J.

1905 A list of Irish Coelenterata, including the Ctenophora. Proceedings of the Royal Irish Academy, Section B, 25:25-92.

STÖSSEL, F. and P. TARDENT

1971 Die Reaktionsmuster von Coryne pintneri und Sarsia reesi (Athecata, Capitata) auf Berührungsreize. Revue Suisse de Zoologie 78:689-697.

SUGIURA, Y.

1977 Occurrence of medusae of the genus Ectopleura from Japanese waters. Annotationes Zoologicae Japonenses 50:36-39.

SUMMERS, R. G.

1970 The fine structure of the spermatozoon of Pennaria tiarella (Coclenterata). Journal of Morphology 131:117130.

1972a An ultrastructural study of the spermatozoon of Eudendrium ramosum. Zeitschrift für Zellforschung und Mikroskopische Anatomic 132:147-166.

1972b A new model for the structure of the centriolar satcllitc complex in spermatozoa. Journal of Morphology 137:229-242.
SUMMERS, R. G. and J. F. HAYNES

1969 The ontogeny of interstitial cells in Pennaria tiarella Journal of Morphology 129:81-88.

SWAINSON, W.

1832 Zoological illustrations, or original figures and descriptions of new, rare, or interesting animals, selected chiefly from the classes of ornithology, entomology, and conchology, and arranged according to their apparent affinitics. Volume 2, 2nd serics. London, Baldwin and Cradock. $91 \mathrm{pp}$.

TARDENT. P. and V. SCHMID

1972 Ultrastructure of mechanoreceptors of the polyp Coryne pintueri (Hydrozoa, Athecata). Experimental Cell Research 72:265-275.

TARDENT, $P$ and F. STÖSSEL

1971 Die Mechanorezeptoren der Polypen von Coryne pintneri, Sarsia reesi und Cladonema radiatum (Athecata, Capitata). Revue Suisse de Zoologie 78:680-688.

THIEL, H.

1962 Clavopsella quadramularia nov. spec. (Clavopsellidae nov. fam.), ein neuer Hydroidpolyp aus der Ostsee und seine phylogenetische Bedeutung. Zeitschrift für Morphologie und Ökologie der Tiere 51:227-260.

THOMPSON, M. T.

1899 The breeding of animals at Woods Holc during the month of September, 1898. Science, n.s., 9:58I-583.

THORNELY, L. R.

1900 The hydroid zoophytes collected by Dr. Willey in the Southern Seas. In Willey, Arthur, Zoological results based on material from New Britain, etc. . 4, pp. 451457.

1904 Report on the Hydroida collected by Professor Herdman, at Ceylon, in 1902. Report to the Government of Ceylon on the pearl oyster fisheries of the Gulf of Manaar, with supplementary reports upon the marine biology of Ceylon, Part 2, pp. 107-126.

TIMMERMANN, G.

1932 Biogcographische Untersuchungen über die Lebensgemeinschaft des treibenden Golfkrautes. Zeitschrift für Morphologie und Ökologic der Tiere 25:288-335.

TORREY, H. B.

1902 The Hydroida of the Pacific Coast of North America, with especial reference to the specics in the collection of the University of California. University of California Publications, Zoology 1: 1-104.

TOTTON, A. K.

1930 Coclenterata. Part V.- Hydroida. British Antarctic ("Terra Nova") Expedition, 1910, Natural History Report, Zoology 5(5):131-252.

1936 Plankton of the Bermuda Oceanographic Expeditions. VIl. Siphonophora taken during the year 1931. Zoologica $21: 231-240$.

1949 An encrusting ceratellid hydroid Rosalinda williami. gen. et sp.n., from the Bay of Biscay. British Science News 3:45-47.

1954 Siphonophora of the Indian Oecan, together with systematic and biological notes on related specimens from other oceans. Discovery Reports 27:1-162. 
UCHIDA, T

1925 Some Hydromedusac from northern Japan. Japanese Journal of Zoology 1:77-100.

1927 Studies on Japanese hydromedusac. 1. Anthomedusae. Journal of the Faculty of Science, Imperial University of Tokyo, Section IV, Zoology 1:145-241.

1930 Beiträge zur Kenntnis der Japanischen Hydromedusen. Zoologischer Anzeiger 88:329-335.

1964 A new hydroid species of Cytaeis, with some remarks on the interrelationships in the Filifera. Publications of the Seto Marine Biological Laboratory 12:133144.

VAN BENEDEN, P. J.

1841 Recherches sur la structure de l'oeuf dans un nouveau genre de polype (genre Hydractinie). Bulletins de l'Académie Royale des Sciences et Belles-Lettres de Bruxelles 8:89-93.

1844a Sur les genres Eleuthérie et Synhydre. Bulletins de l'Académie Royale des Sciences et Belles-Lettres de Bruxelles 11:305-314.

1844b Recherches sur l'embryogénie des tubulaires, et l'histoire naturelle des différents genres de cette famille qui habitent la Côte d'Ostende. Nouveaux Mémoires de l'Académie Royale des Sciences et Belles-Lettres de Bruxelles 17(6): 1-72.

1867 Recherches sur la faune littorale de Belgique (polypes). Mémoires de l'Académie Royale des Sciences, des Lettres et des Beaux Arts de Belgique 36:1-207.

VANHÖFFEN. E.

1911 Die Anthomedusen und Leptomedusen der Deutschen Tiefsee-Expedition 1898-1899. Wissenschaftliche Ergebnisse der Deutschen Tiefsec-Expedition auf dem Dampfer "Valdivia" 1898-1899 19(5):191-233.

VANNUCCI, M.

1951 Hydrozoa e Scyphozoa existentes no Instituto Paulista de Oceanografia. Boletim do Instituto Paulista de Oceanografia 2(1):67-98.

1956 Biological notes and description of a new species of Dipurena (Hydrozoa, Corynidae). Proceedings of the Zoological Society of London 127:479-487.

VANNUCCI, M. and W. J. REES

1961 A revision of the genus Bougainvillia (Anthomedusae). Boletim do Instituto Oceanográfico 11(2):57100.

VERRILL, A. E.

1868 Notice of the corals and echinoderms collected by Prof. C. F. Hartt, at the Abrolhos reefs, Province of Bahia, Brazil, 1867. Transactions of the Connecticut Academy of Arts and Sciences 1:351-371.

1900 Additions to the Anthozoa and Hydrozoa of the Bermudas. Transactions of the Connecticut Academy of Arts and Sciences 10:551-572.

1902a Comparisons of the Bermudian, West Indian, and Brazilian coral faunae. Transactions of the Connecticut Academy of Arts and Sciences 11:169-206.

1902b The Bermuda Islands: their scenery, climate, productions, physiography, natural history, and geology; with sketches of their early history and the changes due to man. Transactions of the Connecticut Academy of Arts and Sciences 11:413-956.

1907 Characteristic life of the Bermuda coral reefs. Transactions of the Connecticut Academy of Arts and Sciences 12:204-348.

VERVOORT, W.

1941 Biological results of the Snellius Expedition. XI. The Hydroida of the Snellius Expedition (Milleporidae and Stylasteridae excluded). Temminckia 6:186-240.

1946a Exotic hydroids in the collections of the Rijksmuseum van Natuurlijke Historie and the Zoological Museum at Amsterdam. Zoologische Mededelingen 26:287351.

1946b Hydrozoa (C I). A. Hydropolypen. Fauna van Nederland, Aflevering 14. $336 \mathrm{pp}$.

1959 The Hydroida of the tropical west coast of Africa. Atlantide Report 5:211-325.

1964 Note on the distribution of Garveia franciscana (Torrey, 1902) and Cordylophora caspia (Pallas, 1771) in the Netherlands. Zoologische Mededelingen 39:125146.

1966 Skeletal structure in the Solanderiidac and its bearing on hydroid classification. In Rees, W. J., ed., The Cnidaria and their evolution. London, Academic Press, pp. 373-396.

1967 The Hydroida and Chondrophora of the Israel South Red Sea Expedition, 1962. Israel South Red Sea Expedition, 1962, Reports 25:18-54.

1968 Report on a collection of Hydroida from the Caribbean region, including an annotated checklist of Caribbean hydroids. Zoologische Verhandelingen 92:1-124.

1972 Hydroids from the Theta, Vema and Yelcho cruises of the Lamont-Doherty Geological Observatory. Zoologische Verhandelingen 120:1-247.

VOGT, C.

1854 Recherches sur les animaux inférieurs de la Méditerranée. I. Sur les siphonophores de la Mer de Nice. Mémoires de l'Institut National Genevois 1:1-164.

WALLACE, W. S

1909 A collection of hydroids made at the Tortugas, during May, June, and July, 1908. Carnegie Institution of Washington, Year Book 7:136-138.

WARREN, E.

1906a On Halocordyle cooperi sp. nov., a hydroid from the Natal coast. Annals of the Natal Government Museum 1:73-81.

1906b On Tubularia solitaria sp. nov., a hydroid from the Natal coast. Annals of the Natal Government Museum 1:83-96.

1907 On Parawrightia robusta gen. et sp. nov., a hydroid from the Natal coast; and also an account of a supposed schizophyte occurring in the gonophores. Annals of the Natal Government Museum 1:187-208.

1908 On a collection of hydroids, mostly from the Natal coast. Annals of the Natal Government Museum 1:269355.

WATSON, J. E.

1978 New species and new records of Australian athecate 
hydroids. Proceedings of the Royal Society of Victoria $90: 301-314$.

1985 The genus Eudendrium (Hydrozoa: Hydroida) from Australia. Proceedings of the Royal Society of Victoria 97:179-221.

WEDLER, E.

1975 Ökologische Untersuchungen an Hydroiden des Felslitorals von Santa Marta (Kolumbien). Helgoländer Wissenschaftliche Meeresuntersuchungen 27:324-363.

WEDLER, E. and R. LARSON

1986 Athecate hydroids from Puerto Rico and the Virgin Islands. Studies on Neotropical Fauna and Environment 21:69-101.

WEERDT, W. H. de

1981 Transplantation experiments with Caribbean Millepora species (Hydrozoa, Coelenterata), including some ecological observations on growth forms. Bijdragen tot de Dierkunde 51:1-19.

WEILL, $R$.

1931 Le genre Pteroclava n.gen., l'interprétation systématique des Pteronemidae (hydraires) et la valeur taxonomique du cnidome. Comptes Rendus Hebdomadaires des Séances de l'Académie des Sciences 182:60-62.

1934 Contribution à l'étude des cnidaires et de leurs nématocystes. II. Valeur taxonomique du cnidome. Travaux de la Station Zoologique de Wimereux 11:351701.

1936 Le cnidome des cladonémides Eleutheria dichotoma et Cladonema radiatum, son cycle et son interprétation. Comptes Rendus Hebdomadaires des Séances de l'Académie des Sciences 203:816-818.

1937a Existence d'un monocnidome dans le médusö̈de d'un polype (Pennaria? tiarella McGr.) à tétracnidome. Comptes Rendus Hebdomadaires des Séances de l'Académie des Sciences 204:1749-1752.

1937b Cladonema radiatum aux Îles Bermudes. Contribution à l'étude des méduses Cladonema. Bulletin Biologique de la France et de la Belgique 71:438-465.

WEIS, J. S.

1968 Fauna associated with pelagic Sargassum in the Gulf Stream. American Midland Naturalist 80:554-558.

WEISMANN, A.

1883 Die Entstehung der Sexualzellen bej den Hydromedusen. Zugleich ein Beitrag zur Kenntnis des Baues und der Lebenserscheinungen dieser Gruppe. Jena, Gustav Fischer. 295 pp.

WERNER, B.

1961 Morphologie und Lebensgeschichte, sowie Temperaturabhängigkeit der Verbreitung und des jahreszeitlichen Auftretens von Bougainvillia superciliaris (L. Agassiz) (Athecatae-Anthomcdusae). Helgoländer Wissenschaftliche Meeresuntersuchungen 7:206237.

1984 Stamm Cnidaria, Nesselticre. In Hartwich, G., F. Kilian, K. Odening, and B. Werner, eds., Lehrbuch der Speziellen Zoologie, Band I: Wirbellose Tiere. 2. Teil: Cnidaria, Ctenophora, Mesozoa, Plathelminthes, Nemertini, Entoprocta, Nemathelminthes, Priapulida. Stuttgart, Gustav Fischer, pp. 11-305.
WESTBLAD, E.

1937 Boreohydra simplex n.gen., n.sp., ein Solitärpolyp von der norwegischen Küste. Arkiv för Zoologi 29B(7): 1-6.

1947 Notes on hydroids. Arkiv för Zoologi 39A(5): 1-23. WILEY, E. O

1981 Phylogenetics; the theory and practice of phylogenctic systematics. New York, John Wiley. 439 pp.

WOLTERECK, $\mathrm{R}$.

1904 Ueber die Entwicklung der Velella aus einer in der Tiefe vorkommenden Larve. Zoologische Jahrbücher, Supplement 7:347-372.

1905 Bemerkungen zur Entwicklung der Narcomedusen und Siphonophoren. (II. Planktologische Mitteilungen aus der Zool. Station in Villefranche s.m.). Verhandlungen der Deutschen Zoologischen Gescllschaft 15:106122.

WRIGHT, T. S.

1858a Observations on British zoophytes.-(1.) On Atractylis (new genus); (2.) On the fixed medusoids of Laomedea dichotoma (living specimens were exhibited); (3.) On the reproductive organs of the medusoid of Laomedea geniculata; (4.) On the reproduction organs of Laomedea lacerata. Proceedings of the Royal Physical Society of Edinburgh 1:447-455.

1858b Observations on British zoophytes. Edinburgh New Philosophical Journal, n.s., 7:282-287.

1859 Observations on British zoophytes. Edinburgh New Philosophical Journal, n.s., 10:105-114.

1861 Observations on British Protozoa and zoophytes. Annals and Magazine of Natural History, 3rd scries, 8:120-135.

1863a Observations on British zoophytes. Proceedings of the Royal Physical Society of Edinburgh 2:59-63.

1863b Observations on British zoophytes.-(1.) On the reproduction of Turris neglecta. (2.) On the development of Hippocrene (Bougairvillea) Britannica(?) from Atractylis (Eudendrium) ramosa. (3.) On the development of Hydra Tuba (Strobila) from Chrysaora. Proceedings of the Royal Physical Society of Edinburgh 2:34-36.

1863c Observations on British zoophytes and Protozoa. 1. Clava nodosa. 2. Acharadria larynx. 3. Zooteirea religata. 4. Freya (Lagotia) obstetrica, Freya stylifer. 5. Chaetospira maritima. 6. Oxytricha longicandata. Proceedings of the Royal Physical Socicty of Edinburgh $2: 378-381$.

YAMADA, M

1959 Hydroid fauna of Japanese and its adjacent waters. Publications from the Akkeshi Marine Biological Station 9:1-101.

1964 Rhizogeton ezoense n.sp., a new hydroid from Hokkaido, Japan. Journal of the Faculty of Science. Hokkaido University, series 6. Zoology 25:395-397.

YAMADA, $M$ and $K$. KONNO

1973 Polyp and medusa of the hydroid Sphaeroconne multirentaculata (Warren) from Japan. Publications of the Seto Marine Biological Liboratory 20:103-109. 



\section{Index}

Acharadia, 52

Acharadria, 52, 53 larvix, 53

Acharadrium, 52

Acies, 77 palpebruns, 78

Acrochordium, 64, 69 album, 69, 70, 72

Actigia, 63, 64

Actinogonium, 63, 64 pusillum, 64

Aglaophenia, 57

Aglatopheria pinnaria, 56

Annalthuea. 48

AMALTHAEIDAE, 48 AMPHINEMIDAE, 35

Anisocalyx pinnarium, 56

Archaradia, 52

Armenista, 80 antarctica, 8 I indica, $8 \mathrm{I}$ lata, 81 lobata, 81 mutica, 81 sigmoides, $8 \mathrm{I}$

Armenistarium, 80 velella, 81

Aselomaris, 15, 19, 23 michaeli, 19

AS YNCOR YNIDAE, 69

Atractilis, 23

ATRACTYLIDAE, 12, 2 I

Atractylis, 23, 24

arenosa, 19

ramosa, 24

Balella, 13, 15 mirabilis, I3

BALELLIDAE, 13 , I5

Bibrachium, 63

Bicorona, 63

Bimeria, 21, 23

lumilis, 21,23

umilis, 2 I

vestita, 21-23

vestita [. nana, 21

BIMERIDAE, 12

BIMERIIDAE, 12, 21

BIMERIINAE, 12, 18, 21

Boreohydra, 48

BOREOHYDRIDAE, 48

BOREOHYDRINAE, 48

Bongaimilla, 23

Bougaimillea, 23, 24 muscilss, 24

ranosa, 24

BOUGAINVILLEAE, 12

Bongaimillia, 19, 21, 23-24, 27, 36 alutumnalis, 24, 27, 28

alutumnalis var, magna, 25

benedenii, 24

britannica, 24, 27

flavida, 24, 27

frondosa, 28

fruticosa, 24

gibbsi, 24

longicirra, 28

macloriana, 23, 24

muscus, I, 24-28

niobe, 28

platygaster, 28

pyramidata, 24, 27

ramosa, I, 24, 27

ramosa f. finticosa, 25

ramosa var. minima, 25

ramosa f. musca, 25

ramosa var, nana, 25

ramosa f. ramosa, 25

ramosa f. vanbenedenii, 25

superciliaris, 27,28

triestina, 25

vanbenedeni, 24

van benedeni, 24

v'anbenedenii, 27

van benedenii, 25

1. benedenii, 24

BOUGAINVILLIIDAE, 12, 13, I4, I5, I8, 19, 23

BOUGAINVILLIINAE, $12,13,15$, I8, 23

BOUGAINVILLIOIDEA, 12

Bouganvilleia, 23

Bourgainvillea, 23

britannica, 24

Bourgainvillia. 23

BRANCHIOCERIANTHIDAE, 48

BRANCHIOCERIANTHINAE, 48

Branchiocerianthus, 48

BYTHOTIARIDAE, 35

Calamella, 38, 52

CALYCOPSIDAE, 36

CALYCOPSIDI. 35

CANDELABRIDAE, 48

Capsularia, 63, 64

CHONDROPHORAE, 76

CHONDROPHOROIDEA, 76

Clirysomitra, 77

striata, 78

Cionistes, 32
CLADOCORYNIDAE, 73, 76

Cladomema, 66-67,68

allmani, 67

californicum, 68

dujardinit, 67

dujardinii, 67

gegenbanri, 67

krohnii, 67

maveri, 67,68

myersi, 68

perkinsi, 67

perkinsii, 67,68

radiata. 67

radiatum, 66, 67-68

radiatum allmani, 67

radiatum dujardinii, 67

radiatum gegenbauri, 67

radiatum krohnii, 67

radiatum var. maveri, 67

sp., 67

uchidai, 67, 68

CLADONEMATIDAE, 66

CLADONEMIDEN, 66

Clava, I0, I2, 52

parasiticum, 6

Clavactinia, 32, 33

Clavatella multitentaculata, 6I

CLAVIDAE, 5, I2, I3, I5, I9

CLAVINAE, 5

CLAVIPTERIDAE, 69

Clavopsella, 13, 14, I5, I7, I9

anmelata, 15, 16

quadranularia, 15

weismanni, I5, I6

CLAVOPSELLIDAE, 12, 13, 15

CLAVOPSELLINAE, I3

Clavopsis, 32, 33 adriatica, 33

Clavula, 7,8 gossii, 8,9

Cnidostoma, 28

CODONIDAE, 63

CODONIIDAE, 63

Codoninum, 63

Cordylophom, 5, 6, I5, I9

ammulata, 15

neapolitana, 15

CORDYLOPHORINAE, 5

Corina, 63, 64

Corine, 63.64

CORYDENDRIINAE, I. 5

Corvdendrium, 5-6, 7, 10

dendriforme, 6,7

dendriformis, 6

flabellatum, 6. 7 
fruticosum, 7

nurricula, 8

parasiticum, 6-7

parasticiun, 6

sessile, 6,7

splendidum, 56

Corvmbogonimm, 39

capillare, 41

Corymorpha, 48, 49

solitaria, 49

COR YMORPHIDAE, 48-49, 76

CORYMORPHINAE, 48, 49

Coryna, 63, 64

Corvne, 6, 39, 52, 63-64, 65, 69, 70

briareus, 70

filiformis, 66

hincksii, 66

implexa, 21, 70

margarica, 21

(margarica) implexa, 70

multitentaculata, 61

pelagica, 70

pintneri, 66

pusilla, 64, 72

sargassicola, 1, 3, 64-66

sessilis, 69, 72

stanridia, 67

starridiai, 67

lanbenedenii, 64

Corynetis

agassizii, 70

CORYNIDAE, 60, 63, 66, 67, 73

CORYNIPTERIDAE, 68

Conynitis

agassizii, 70, 72

Corynopsis, 27

alderi, 24, 27

Ctenaria, 69

Cubogaster, 29

Cunina

octonaria, 10

Cyanaea

bougainvillii, 24

Cybogaster, 29

gemmascens, 29

Cyacis, 29

CYTAEIDAE, 28

CYTAEIDIDAE, 12, 28-29, 3I, 32

Cytueidium, 29

Cytueis, 28, 29, 31

imperialis, 31

japonica, 29, 3 I

nassa, 31

niotha, 31

muda, 3 I

pusilla, 29

sp. 29-31

tetrastyla, 29, 31

uchidae, 29, 31 uchidai, 31

Crucsis, 29

Cyteis, 29

Cytheis, 29

Dendroclara, 7

Dendronema, 67

DENDRONEMIDAE, 66

DICODONIINI, 63

Dicoloniam, 63

Dicoryne, 23

capillare. $4 \mathrm{I}$

DICORYNIDAE, 12

Dicyclocoryne, 63

DICYCLOCOR YNIDAE, 63

Dipurena, 63, 65

reesi, 68

strangulata, 68

Discalia, 77

primordialis, 78

DISCALIDAE, 76

Disconalia, 77

gastroblasta. 78

pectyllis. 78

ramifera, 78

Ectopleura, 52-53

dumortierii, 53

kavix, 55

minerva, 53, 54, 55

pacifica, 53-55

sp., 53, 54

Edendrium, 39

Elewtheria, 68

mulitentaculata, 61

perkinsii, 67

radiata, 67

ELEUTHERIIDAE, 66

Erudendium, 39

Eucoryna, 55

elegans, 56

Eucoryne, 55, 56, 63, 64

elegans, 56

Eucorynus, 56

EUDENDRIIDAE, 12, 18, 38, 39, 46

Eudendrium, 23, 27, 38-39, 42, 43 . 44, 46, 64

amboinensis, 46

angustum, 40

attentuatum, 44

aylingae, 40

bermudense, 1, 39-41

capillare, 41-43

capillare var. mediterranea, 41

carneum, 19, 22, 25, 43-45, 49. 50

cochleallum, 44

cunninghami, 43

currumbense, 40 distichum, 44

exigunum, 44

eximium, 44

fruticosum, 44

glomerantm, 40

gracile, 44

griffini, 46

hargettii, 46

liargitii, 46

hyalinum, 43

infundibuliforme, 40

laxzmn, 44

morzkossowskite, 38,40

parvmun, 41, 43

remosum, 24, 27, 41, 43, 44

tencllım, 42, 43, 44

temue, 41, 43

EUDENDROIDAE, 38

Eliphysa, 48

globator. 56

EUPHYSIDAE, 48

EUPHYSINAE, 48

Fistulana, 1, 39, 63, 64

Fistularia, 63, 64

Garveia, 21, 23

franciscana, 21

hunnilis, 21

mutans, 2I

robusta, 19

Gemellaria, 69

implexa, 70

Gemmaria, 69

cladophora. 70

costata, 70

gemmosa, 70, 72

implexa, 70

implexa var. neapolitana, 70

sagittaria, 70

sergittata, 70

sp. . 70

Globiceps, 55, 56

globator, 56

tiarella, 55, 56

Guentherella, 69

implexa, 70

Gymmocoryne, 69

coronata, 70

Gymmogonos, 48

HALECIIDAE, 29

Halecium, 39

Halerella, 32

HALIMEDUSIDAE, 35, 36

Halobotress, 63

Halocharis, 69

gemmosa, 70

spiralis, 70 
Halocordile, 55

disticha, 56

Halocordyle, 23, 55-56

anstralis, 56, 58

cooperi, 56

disticha, 56-60

disticha var. alstralis, 56

fingilis, 56

pennaria var. alustralis, 56

tiarella, 56

wilsoni, 56

HALOCORDYLIDAE, 55

Halvbothrys, 63

Halybotrys, 63, 64

Hamsiella, 32

Hermia, 63, 64

Hippocrene, 23

HIPPOCRENIDAE, 12

Holothuria

denudina, 77

muda, 77

spirans, 81

Holothurio

demulata, 77

spirans, 81

HYBDOCORIDAE, 52

Hybocodon, 52

HYBOCODONIDAE, 52

Hydractinia, 32, 33

arge, 33

prwoti, 33

HYDRACTINIDAE, 31

HYDRACTINIIDAE, I2, I4, 29.

\section{1-32, 33}

HYDRACTINIINAE, 32

HYDRACTINIOIDEA, 32

Hidractomma, 32, 33

Hydranthea, 28, 29

HYDRICHTHYIDAE, 36

HYDRICHTHYINAE, 35, 36

Hydrichthys, 36

mirus, 36

Hydrissa, 32, 33

Hydrocorella, 32, 33

Hydroconne, 63

HYDROCORYNIDAE, 63

Hydronema, 32

HYPOLYTIDAE, 48

Hypolytus, 48

Hyppocrene, 23

Janaria, 32, 33

JANARIIDAE, 31

Kinetocodium, 32, 33

Koellikerina, 21

fasciculata, 21
Leackartiara

vestita, 21

vestita f. mana, 21

Linvillea, 60, 63 agassizii, 60, 6I, 72

Lizusa, 23, 24

8-cilicita, 24

octocilia, 24

octociliata, 24

LIZUSIDAE, 12

Lizuza, 23

Lizzia, 29

blondina, 29

LIZZIINAE, 12

Manicella, 21

fusca, 21, 22, 23

MARGELIDAE, 12

Margelis, 23, 24

altumnalis, 24

principis, 24

ramosa, 24

MARGELOPSIDAE, 76

Medlusa, 77

duodecilia, 27

glandifera, 78

nuda, 77

ocilia, 27

octocilia, 24, 27

pocillum, 81

porpita, 77

sexdecilia, 27

umbella, 77

velella, 81

Merona, 5

Millardiana, 13

longitentaculata, 13-14

Millepora, 2, 73

alcicornis, 1, 73-76, 84

alcicormis var. cellulosa, 74

alcicormis corniculata, 73

alcicornis crustacea, 73

alcicornis digitata, 73

alcicornis var. fenestrata, 74

alcicornis ramosa, 73

alcycornis, 73

alicornis, 73

candida, 74

carthaginiensis, 74

complanata, 74, 76

crista-galli, 73

crustacea, 73

delicatula, 74

digitata, 74

esperi, 73

fasciculatu, 73

fenestrata, 74

forskali, 73

gothica, 73 moniliformis, 73

nitiela, 74

pumila, 73

ramosa, 73

schrammi, 73

squarrosa, 74, 76

trinitatis, 74

MILLEPORADAE, 72

MILLEPORIDAE, 72-73, 76

Mnestra, 69

implexa, 70

parasites, 69, 70

Modeeria

multitentacula, 8,9

multitentaculata, 8

mutricola, 8

mutricula, 8

MOERISIIDAE, 60

MONOCAULIDAE, 48

Monocaulus, 48

Montipora

gothica, 74

Myrionema, 38, 46

amboinense, 40, 46-48

amboinensis, 46

griffini, 46

hargitti, 46, 48

MYRIONEMIDAE, 38

MYRIOTHELIDAE, 48

NEMOPSIDAE, I 2

Nemopsis, 23

Nigritina, 29

NIOBIIDAE, 35, 36

Oceania

mutricula, 8

polycirrha, 8,9

Oonantes, 69

OR'THOCORYNIDAE, 68

Pachycordile, 14

weismanni, 15

Pachycordyle, I, 13, 14-15. 17, 19

anmulata, 16

napolitana, I4, 15-16

neapolitana, 15

weismami, 15, 16, 19

PACHYCORDYLINAE, 12, 13, 15. I8

PACHYCORDYLINI, I, 12, 13

Palmipora, 73

alcicornis, 73

fusciculatu, 73

parasitica, 73

PANDAEIDAE, 35

PANDEIDAE, 35,36

PANDEOIIEAA, 35-36

Paracymeis, 28 
PARAGOTOEIDAE, 48

Parnirightia, 1. 18-19

robusta, 19-20

Parigonimas, 23

Parvenemus, 14, 15

degeneratus, 15

Pelagiana, 36

richodesmiae, 35, 36-38

Permuria, 55. 56

adamsia, 56

"americana," 56

unstralis, 56. 58

unstralis var. cooperi, 56

crulini, 56

cavolina, 56

cavolini, 56

covolinii, 56

disticha, 55, 56.57

disticha var. anstralis, 56

distveha. 56

"curopea." 56

gibbosa, 56

inornata. 56

pacifica, 56

parasitica, 6

pennaria, 56

rosea, 56

symetrica, 56

simmetrica, 56

tiarella, 56. 57

wilsoni, 56

PENNARIIDAE, 55

Perarella, 28, 29, 32

Perigominus, 23

Perigommms, 23

Perigonella, 32

Perigonemils, 23

Perigonimus, 23, 24, 36

cidlaritis, 21

muscoides, 24

nopolitamus, 15

neapolitanus, 15

vestita, 21

lestitus, 21

Perigonismus, 23

Perigonymus, 23

muscus, 24

ramosus, 24

Perinema, 64

Phyllidoce, 77, 80

demudata, 77

porpita, 77

velella, 77.81

Phyllodice

denudata, 78

velella, 81

Plumularia

pennaria, 56

Podocorella, 32
Podocoryna, 27, 32, 33

fucicola, 32

simplex, 31

Podocorve, 32

alderi, 1, 24. 27

borealis, 27

sarsii, 32

tubulariae, 27

PODOCOR YNIDAE, 31

Polvbrachionia, 77

linnaeana, 78

POLYPI, 52

Porpalia, 77

PORPALIDAE, 76

Porpema, 77

Porpita, 2, 76, 77

appendiculata, 77

atcantica, 77

chrysocoma, 77

coerulea, 77

forskihli, 78

forskalea, 77

fungia, 78

gigantea, 77

glandifera, 77

globosa, 77

granulata, 77

indica, 77

kuhlii, 78

linncleana, 78

lutkeana, 78

mediterranea, 78

moneta, 77

muda, 77

pacifica, 77, 78

porpita, 1, 77-80

radiata, 77

ramifera, 77

reimwardtii, 78

umbella, 78

PORPITAE, 76

Porpitella, 77

caerulea, 78

coerulea, 78

pectanthis, 78

raliata, 78

PORPITELLIDAE, 76

PORPITIDAE, 76-77

PROTIARIDAE, 35, 36

Pteroclata, 69

Pteronema, 69

darwinii, 69

PTERONEMATIDAE, 69

PTERONEMATOIDEA, 76

PTILOCODIIDAE, 32

Rataria, 80

cordata, 81

cristata, 81 mitrata, 81

porillum, 81

Rutis, 77

medusae, 78

Rhizodendrinm, 1, 5, 10

ezoense, 11,12

nudirm, I1, 12

sterreri, 1, 10-12

Rhizogeton, 10

ezoense, 10

fisiformis, 10, 11

nematophorns, 10

nudhum, 12

nuthis, 10

Rhizohydra, 32

RHIZORHAGIINAE, $1,12,18$

Rhizorhagium, 18, 19, 20 napolitanmm, 15

navis, 15

robustum, 19

rosellm, 19

RHYSIIDAE, 32

Rosalinda, 69

ROSALINDIDAE, 69

RUSSELLIIDAE, 12

Sarsia, 63, 64, 65, 67

lovenii, 66

mirabilis, 64

occulta, 66

tubulosa, 64, 65, 66

SARSIADAE, 63

Sarsiella. 63

Sertolara, 56

parassita, 6

pennara, 56.57

Sertularia, 52, 56

halecina, 39

parasitica, 6

pennaria, $56,57,84$

ramosa, 24, 27

Sertulariam

parasiticam, 6

Silhometta, 13, 15, 16-17, 19

phertoricensis, 17, 18

wacarpa, 13, 17-18

Soleniopsis, 5.6 dendriformis, 6

Sphaerocoryne, 60-61, 63

bedoti, 60, 61-62

multitentaculata, 60, 61, 62

peterseni, 61

sp.. 61

SPHAEROCORYNIDAE, 60, 63

Stciuridia, 64, 66, 67

producta, 67

raliatum, 67

STAURIDIIDAE, 66

Stanridiosarsia, 63,64,67 
Stauridium, 66 cladonema, 67

Staurocladia, 68

Staurocorvine, 63, 64

Steenstrupia, 48

STEENSTRUPIINI, 48

Stipula, 63, 64

Stomotoca, 36 pterophylla, 36

STOMOTOCIN1. 35

Strilactaria, 1, 32-33

arctica, 33

arge, 33-35

carcinicola, 33

claviformis, 33

hooperii. 35

inermis, 33

ingolfi, 33

pisicola. 33

verii, 33

Stylactella, 28, 29, 32

abyssicola, 32

spongicola, 32

vermicola, 32

STYLACTIDAE, 28, 31, 32

Strlactis, 28, 32, 33

arge. 33

fuciola, 32

hoopei, 33

hooperi. 33

hooperii, 33

indica, 31

inermis, 32, 33

sp.. 33, 35

vermicola, 28

STYLASTERIDAE, 32, 72

Styllactis

hooperi var. minor, 33

Sincorine, 63

Syncoryna, 6, 63, 64

parcisitica, 6

pusilla, 64

Synconne, 63

mirabilis, 64, 65, 66

parasitica, 6

sp., 64, 65, 66

stauridium, 67

SYNCOR YNIDAE, 63

Sytlactis:

arge, 33

Teissiera, 69

australe, 69

medusifera, 69

milleporoides, 69
TEISSIERIDAE, 69, 73, 76

Thamnostoma, 21

rissselli, 21

sp., 21

THAMNOSTOMIDAE, 12

THAMNOSTOMINAE, 12, 21

Thod, 39

savignii, 39

Tiara, 36

TIARIDAE, 35, 36

Timoides

agassizii, 36

TIMOIDIDAE, 35, 36

Tregoubovia, 32

TRICHORHIZINI, 48

TRICHYDRIDAE, 35, 36

TRICHYDROIDEA, 36

Tubiclava, 5, 10

ammulata, 15

fruticosa, 16

TUBIDENDRIDAE, 13

Tubularia, 49.52

dumortierii, 53

implexa, 70

muscoides, 1, 39, 64

pacifica, 53

ramea, 39

ramosa, 24, 27, 39, 64

solitaria, 1, 49, 50

spongicola, 50

TUBULARIADAE, 52

TUBULARIAE, 52

TUBULARIIDAE, 49, 52, 76

TUBULARIOIDEA, 76

TURRIDAE, 5

Turris, 5, 8

neglecta, 8, 9

Turritopsis, 5, 6, 7-8, 10

dohmii, 9, 10

fascicularis, 10

mutricola, 8

mutricola var. pacifica, 8

nutricula, 5, 8-10

policirrha, 8

polynema, 8, 9

Tiurutopsis, 7

nutricula, 8

Velaria, 80

indica, 81

mutica, 81

oblonga, 81

Velella, 2, 76, 77, 80-81

antarctica, 81

aurora, 81 australis, 81

callrina, 81

cranea, 81

emarginata, 81

indica, 81

lata, 81

limbosa, 81

meridionalis, 81

mutica, 81

oblonga, 81

oryothone, 81

oryothome var. brachothome, 81

orvothone var. oxvothone, 81

pacifica, 81

patella, 81

patellaris, 81

pocillum, 81

pyramialalis, 81

radackiana, 81

sandwichiana, 81

scaphlidia, 81

septentrionalis, 81

sinistra, 81

spiralis, 81

spirans, 81

subemarginata, 81

tentaculata, 81

tropica, 81

velella, 1, 77, 78, 81-84

VELELLIDAE, 76

Vellela, 80

limbosa, 81

Wrighria, 19

Zanclea, 69, 70

alba, 69-72

cladophora, 70

costata, 69, 70, 72

gemmosa, 70, 72

hargitti, 70

implexa, 70, 72

inflexa, 70

sagittaria, 70

sessilis, 70,72

ZANCLEIDAE, 64. 68-69.73. 76

ZANCLEOIDEA. 77

Zanklea, 69

costata, 70

Zanlicea, 69

Zl:zigus, 49

Zyzzl:zus, 49

solitarius, 49

spongicolus. 50

warreni, 1.49-51,84

Zy:zyzuz, 49 



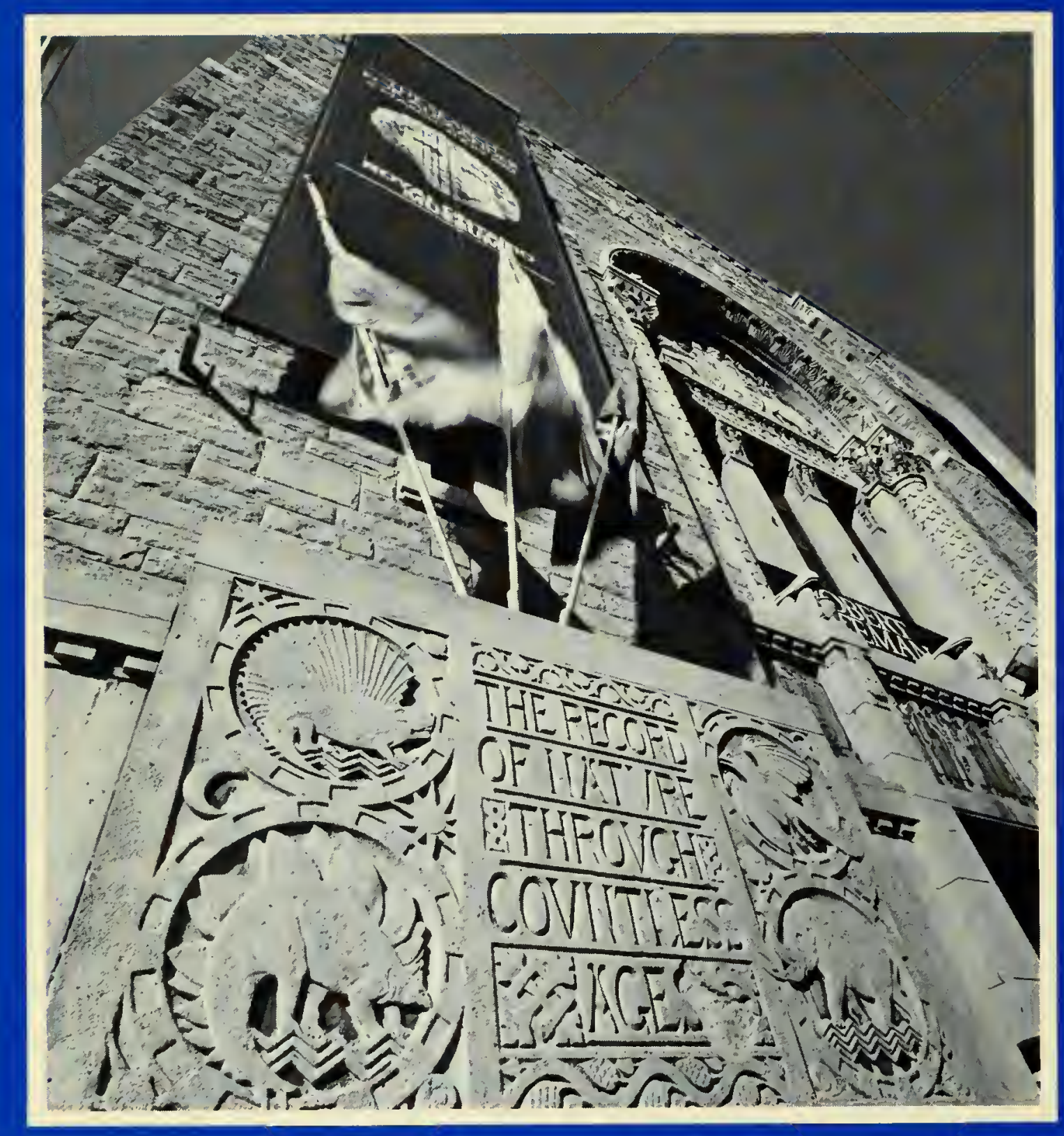

ISBN 0-88854-339-5

ISSN 0384-8159 